
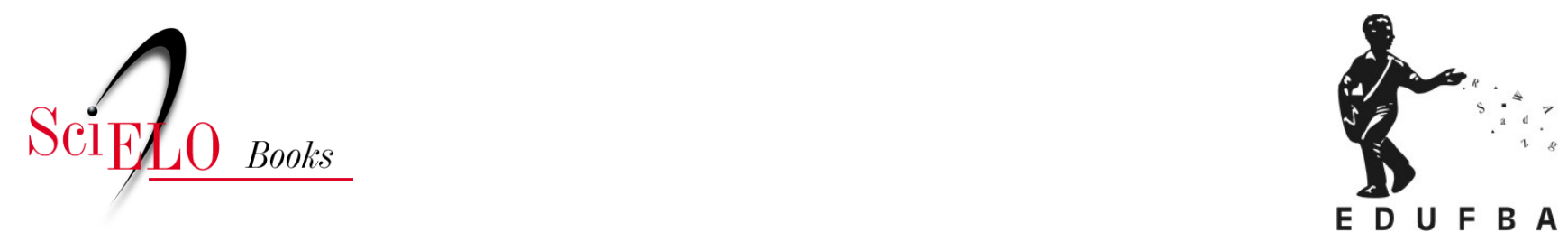

\title{
Estudos de saúde, ambiente e trabalho aspectos socioculturais
}

\author{
Mônica Angelim Gomes de Lima \\ Maria do Carmo Soares de Freitas \\ Paulo Gilvane Lopes Pena \\ Sérgio Trad \\ (orgs.)
}

LIMA, M.A.G., FREITAS, M.C.S., PENA, P.G.L., and TRAD, S., orgs. Estudos de saúde, ambiente e trabalho: aspectos socioculturais [online]. Salvador: EDUFBA, 2017, 206 p. ISBN: 978-85-232-18645. http://doi.org/10.7476/9788523218645

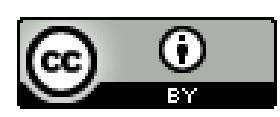

All the contents of this work, except where otherwise noted, is licensed under a Creative Commons Attribution $\underline{4.0 \text { International license. }}$

Todo o conteúdo deste trabalho, exceto quando houver ressalva, é publicado sob a licença $\underline{\text { Creative Commons }}$ Atribição 4.0.

Todo el contenido de esta obra, excepto donde se indique lo contrario, está bajo licencia de la licencia $\underline{\text { Creative }}$ Commons Reconocimento 4.0. 


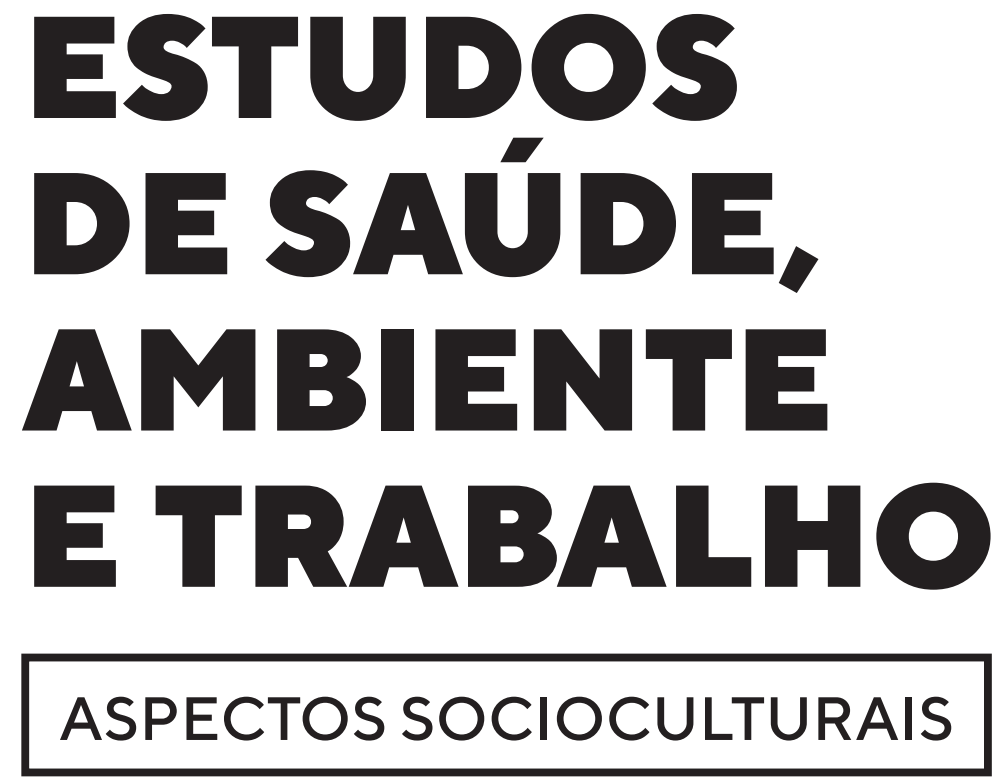

Mônica Angelim Gomes de Lima Maria do Carmo Soares de Freitas

Paulo Gilvane Lopes Pena

Sérgio Trad

(ORGANIZADORES) 


\section{UNIVERSIDADE FEDERAL DA BAHIA}

REITOR João Carlos Salles Pires da Silva viCe-Reitor Paulo Cesar Miguez de Oliveira ASSESSOR DO REITOR Paulo Costa Lima

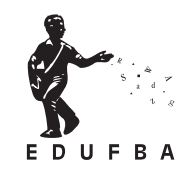

EDITORA DA UNIVERSIDADE FEDERAL DA BAHIA

\section{DIRETORA}

Flávia Goulart Mota Garcia Rosa

CONSELHO EDITORIAL

Alberto Brum Novaes

Angelo Szaniecki Perret Serpa

Caiuby Alves da Costa

Charbel Ninõ El-Hani

Cleise Furtado Mendes

Evelina de Carvalho Sá Hoisel

José Teixeira Cavalcante Filho

Maria do Carmo Soares de Freitas

Maria Vidal de Negreiros Camargo 


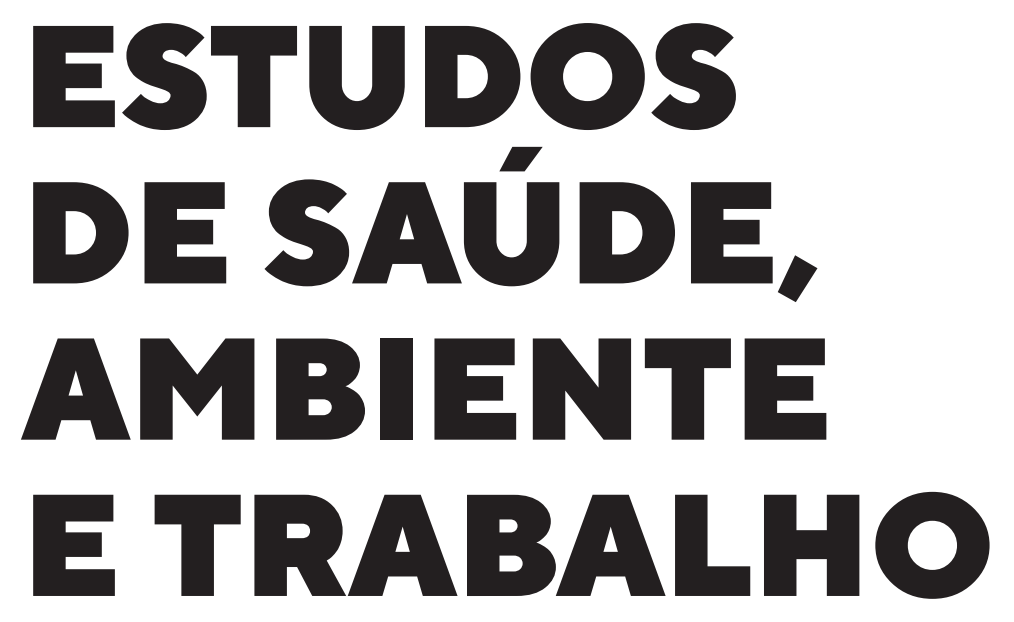

\section{ASPECTOS SOCIOCULTURAIS}

Mônica Angelim Gomes de Lima

Maria do Carmo Soares de Freitas

Paulo Gilvane Lopes Pena

Sérgio Trad

(ORGANIZADORES)

Salvador

EDUFBA

2017 
2017, Autores.

Direitos dessa edição cedidos à Edufba.

Feito o Depósito Legal.

Grafia atualizada conforme o Acordo Ortográfico da Língua Portuguesa de 1990, em vigor no Brasil desde 2009.

CAPA E PROJETO GRÁfico Gabriel Cayres

REVISÃo E NORMALIZAÇÃo Elber de Oliveira Lima e Cecília Nascimento da Silva

SISTEMA DE BIBLIOTECAS - SIBI/UFBA

Estudos de saúde, ambiente e trabalho : aspectos socioculturais / Mônica Angelim Gomes de Lima [et. al.] ... (organizadores).- Salvador: EDUFBA, 2017.-

$206 \mathrm{p}$.

ISBN: 978-85-232-1683-2

1. Ambiente de trabalho. 2. Doenças profissionais. 3. Segurança do trabalho. I. Lima, Mônica Angelim Gomes de.

CDD: 363.11

Editora afiliada à

$\because \mathrm{T}=\mathrm{O}$

ASOCIACION DE EDITORIALES ASOCIACION DE EDITORIALES LATINAY Y EL CARIBE

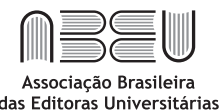

das Editoras Universitárias

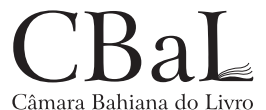

Câmara Bahiana do Livro

Editora da UFBA

Rua Barão de Jeremoabo

$\mathrm{s} / \mathrm{n}$ - Campus de Ondina

40170-115 - Salvador - Bahia

Tel.: +55 71 3283-6164

Fax: +55 $713283-6160$

www.edufba.ufba.br

edufba@ufba.br 


\section{SUMARIO}

\section{APRESENTAÇÃo}

\section{CAPÍtULO 1}

O Sonho Metalúrgico? Trabalho, desenvolvimento e adoecimento no contexto de um complexo automotivo Jorge Henrique Santos Saldanha, Mônica Angelim Gomes de Lima e Robson da Fonseca Neves

\section{CAPÍTULO 2}

Confinamento em alto mar de militares da Marinha do Brasil e repercussões na qualidade de vida Ana Carolina Nascimento de Albuquerque Ramose Paulo Gilvane Lopes Pena

\section{CAPÍTULO 3}

Condições de trabalho e riscos em uma central de regulação médica de urgência: o caso dos técnicos auxiliares de regulação médica - TARM Tarciso de Figueiredo Palma, Paulo Gilvane Lopes Pena e Rita de Cássia Pereira Fernandes

\section{CAPÍTULO 4}

Conflitos e estratégias dos trabalhadores de enfermagem na emergência de uma maternidade pública Manoel Henrique de Miranda Pereira, Paulo Gilvane Lopes Pena e Rita de Cássia Pereira Fernandes

\section{CAPÍTULO 5}

Reflexões sobre escolhas alimentares de nutricionistas com obesidade Kênya Lima Araújo, Paulo Gilvane Lopes Pena e Maria do Carmo Soares de Freitas 


\section{CAPÍTULO 6}

Balbina de Jesus: um estudo de caso sobre a organização do trabalho informal de feirante - concepção, execução e cuidado de si

Saulo Robledo Cardoso, Maria do Carmo Soares de Freitas e Rita de Cássia Pereira Fernandes

\section{CAPÍtULO 7}

Os mineiros do amianto: da lã do minério à contaminação do mal

Claúdia de Oliveira d'Arede, Maria do Carmo Soares de Freitas e Mônica Angelim Gomes de Lima

\section{CAPÍtULO 8}

“Marés de dor”: as mediações do corpo no cotidiano das marisqueiras

Thais Mara Dias Gomes, Sérgio Trad e Mônica Angelim Gomes de Lima

\section{CAPÍtULO 9}

Riscos ocupacionais na coleta de materiais recicláveis: percepção e condicionantes em uma cooperativa familiar Denise Alves Miranda de Oliveira, Luis Roberto Santos Moraes e Sérgio Trad

191 CAPÍtULO 10

Além da etnografia: olhares sobre o trabalho dos pesquisadores

Cristina Larrea Killinger 


\section{Apresentação}

Este livro reúne em dez capítulos alguns estudos da temática sobre Saúde, Ambiente e Trabalho em sua versão com a pesquisa qualitativa. Este campo, na perspectiva das teorias compreensivas, caminha em direção à análise de narrativas dos sujeitos implicados no processo de trabalho. Em todos os lugares desses cotidianos etnográficos analisados aparecem, do empírico ao ético, saberes sobre a saúde e a experiência de viver e adoecer no trabalho. A práxis social está implícita e conjugada à lógica causal das ciências biológicas aqui humanizadas pelos sentidos dos sujeitos, protagonistas dessas estruturas de leituras reconhecidamente interdisciplinar. Destaca-se, sobretudo, um diálogo com a análise ergonômica do trabalho.

Algumas reflexões de cunho sócioantropológico surgem nas cenas do trabalho ocupacional e ambiental e definem uma abrangência dessa temática compartilhando a compreensão humana e os significados da saúde para os sujeitos. Uma condição humana intrinsecamente marcada pela intersubjetividade. Nesse aspecto, os problemas de saúde do corpo e do ambiente aparecem como categorias que recortam a invisibilidade do adoecimento, impactos para vida social, identidade de trabalhador, gestão da força de trabalho, do clássico ao contemporâneo em que a estética e o assédio moral se assemelham.

O capítulo "O Sonho Metalúrgico? Trabalho, desenvolvimento e adoecimento no contexto de um complexo automotivo” analisa enunciados de 
metalúrgicos e a relação adoecimento, capital e trabalho. O segundo, “Confinamento em alto mar de militares da marinha do Brasil e repercussões na qualidade de vida”, mostra o confinamento de marinheiros, seus conflitos com o isolamento e o contexto familiar. Na sequência, o terceiro, "Condições de trabalho e riscos em uma central de regulação médica de urgência: o caso dos técnicos auxiliares de regulação médica - TARM”, apresenta o lugar do cuidado desafiador na análise das condições de trabalho e riscos em uma central de regulação médica de urgência. No quarto capítulo, "Conflitos e estratégias dos trabalhadores de enfermagem na emergência de uma maternidade pública”, há uma sutil e impressionante, correspondência entre as enfermeiras e seus conflitos sociais e humanos, em uma maternidade pública. E no quinto, "Reflexões sobre escolhas alimentares de nutricionistas com obesidade”, se valorizam enunciados de nutricionistas portadoras de obesidade e suas dificuldades em trabalhar e viver no mundo contemporâneo de corpos esteticamente regulados pelo mercado consumidor. Em seguida, no sexto capítulo, "Balbina de Jesus: um estudo de caso sobre a organização do trabalho informal de feirante - concepção, execução e cuidado de si”, um estudo de caso mostra em fragmentos biográficos sensíveis, a história de uma feirante e sua sobrevivência. O capítulo sete, “Os mineiros do amianto: da lã do minério à contaminação do mal”, dá lugar aos mineiros do amianto no interior da Bahia, com o trabalho degradante e um ambiente enfermo. No oitavo, “Marés de dor': as mediações do corpo no cotidiano das marisqueira”, são as dores de trabalhar e viver na maré,o corpo a mariscar sob o sol intenso e as dores que parecem inevitáveis ao trabalho. Mais adiante, o capítulo nove, "Riscos ocupacionais na coleta de materiais recicláveis: percepção e condicionantes em uma cooperativa familiar”, traz as noções de riscos ocupacionais na coleta de materiais recicláveis, e finalmenteno último capítulo, “Além da etnografia: olhares sobre o trabalho dos pesquisadores”, a pesquisadora escreve para além da etnografia, fala com emoção de seu trabalho e dos significados para o outro.

Espera-se que esses estudos possam refletir a história do padecimento no trabalho, seus contextos, e a polissemia que envolve o mundo do trabalho no capitalismo brasileiro e a saúde. 


\title{
O Sonho Metalúrgico? Trabalho, desenvolvimento e adoecimento no contexto de um complexo automotivo
}

\author{
JORGE HENRIQUE SANTOS SALDANHA \\ MONNICA ANGELIM GOMES DE LIMA \\ ROBSON DA FONSECA NEVES
}

"A expectativa era muito grande. Acho que no meu caso particularmente, para eu trabalhar numa montadora, saber falar em fabricar um carro, para mim, (suspiro) Ave Maria, era tudo! E aí foi que o sonho virou realidade”. (Fala de João, metalúrgico, sobre a expectativa de entrar no CIEN) ${ }^{1}$

A epígrafe acima revela o imaginário presente nos trabalhadores do município de sede, Camaçari, quando ocorreu a instalação do CIEN na cidade. A chegada de uma empresa multinacional na cidade, trazida no contexto de uma política macroeconômica de migração de capitais para regiões periféricas e de uma política de desenvolvimento regional da indústria brasileira, animava os trabalhadores da cidade, que viam na chegada do CIEN a oportunidade de conquistar um trabalho fixo, melhoria das condições de vida e reconhecimento social, já que apesar da expansão industrial, que a

1 Complexo Industrial Empresa Nordeste. 
cidade tinha vivido no ciclo anterior motivado pela indústria petroquímica, não ter produzido na cidade a formação de um contingente de trabalhadores industriários com boas condições de vida, pois o setor petroquímico, mesmo instalado no município, absorveu, como emprego primário, operários qualificados que moravam em Salvador, deixando para os moradores do município sede os empregos terceirizados.

O município sede, ao qual se refere aqui, está situado na região metropolitana de Salvador (RMS) a $41 \mathrm{~km}$ da capital. Tem uma população aproximada de 242.984 mil habitantes, sendo 120.626 homens e 122.358 mulheres. (IBGE, 2010) Possui o maior PIB (Produto Interno Bruto) industrial do Nordeste, de $\mathrm{R} \$ 8$ bilhões, e sua economia corresponde a 8,67\% do PIB estadual. Esse cenário é possível, graças à posição em que ocupa na industrialização baiana, correspondendo a 35\% da industrialização do estado, com isso o município possui o maior PIB per capita da Bahia. (IBGE, 2010)

O Complexo Industrial Empresa Nordeste tem capacidade para produzir 250 mil veículos por ano. A planta reúne sob o mesmo teto a empresa e 27 parceiros que fornecem sistemas para os veículos diretamente na linha de montagem em um sistema de condomínio industrial. ${ }^{2}$ A planta possui um alto padrão de automação industrial, contando com mais de 512 robôs e sistemas eletromecânicos de automação, com um modelo de produção chamado montagem modular sequenciada, aplicado pela primeira vez dentro da Empresa Mundial. Seu principal diferencial é a participação de fornecedores diretamente na linha de montagem e no processo de produção, e não apenas no fornecimento dos componentes do veículo, compartilhando das instalações e das responsabilidades. (FORD MOTOR COMPANY, [201-])

Ismar Sena (2009) destaca que, a partir da implantação do Regime Automotivo Especial, a Bahia recebeu o interesse de várias montadoras, que se habilitaram para construir empreendimentos em estados como Bahia, Ceará, Goiás, Tocantins e Acre. Vinte e cinco empresas haviam se comprometido a investir 3,53 bilhões de dólares nesses estados, sendo que a Bahia

2 O condomínio industrial é uma configuração, na qual alguns fornecedores escolhidos pelas montadoras se instalam junto às plantas das indústrias, objetivando reduzir custos em estoques, processos, transporte e facilitar a integração entre os parceiros. Os condomínios industriais permitem que as empresas centrais estabeleçam com outras empresas menores relações, mais distantes, de apenas entregas de pequenos lotes -Just in time - até o processo atual de fornecimento de subconjuntos ou subsistemas completos na linha de montagem, aumentando a corresponsabilidade das empresas no processo produtivo. (SALERNO; MARX; ZILBOVICIUS, 2003) 
receberia investimentos que representariam 50\% desse valor. Ao analisar o montante de isenções fiscais recebido pela empresa para instalar sua planta na Bahia, Sena (2009, p. 73) manifesta:

[...] É interessante observar que o total de incentivos concedidos à Empresa, que somaram à época $\mathrm{R} \$ 2.402$ bilhões seria suficiente para construir com sobras as fábricas das outras três montadoras, visto que a soma dos incentivos concedidos à Renault, General Motors e Mercedes foi da ordem de R \$ 1.804 bilhões.

É nesse cenário de incentivos fiscais vultosos e pouca ênfase dada às condições de trabalho dos milhares de trabalhadores e trabalhadoras, que ingressariam nessa corrida pelo ouro, motivados pelo fato de que o setor metalúrgico automotivo, apesar de novo no estado da Bahia, já aparece como um dos maiores setores da indústria, tanto no volume arrecadado quanto no número de empregos gerados. De fato o complexo industrial automotivo é responsável por cerca de nove mil empregos diretos, sendo que a maioria dos empregos está relacionada com a atividade de produção. (FIEB, 2010; SENA, 2009) Mas, questiona-se qual o impacto da instalação do CIEN nessa cidade e qual a relação desse processo produtivo com o adoecimento de trabalhadores metalúrgicos?

Neste capítulo descrevem-se: o contexto de implantação do complexo automotivo vivenciado pelos trabalhadores, as expectativas com a sua chegada, o processo de construção de uma identidade metalúrgica na cidade, o papel do trabalho como instrumento de satisfação na vida dos trabalhadores do complexo e o impacto econômico e social da instalação do CIEN na cidade. Ao longo das conversações, são descritas as contradições entre as expectativas e a realidade do processo produtivo vivenciada pelos metalúrgicos, assim como apontadas explicações emergentes sobre o modelo de produção como determinante no adoecimento no setor automotivo e nas relações entre os trabalhadores e as empresas.

\section{Caminhos metodológicos}

Trata-se de um estudo exploratório apoiado em uma abordagem etnográfica. As interlocuções nos levaram a aproximações com o contexto local de um município que sofreu inúmeras transformações em curto espaço de tempo com a implantação do CIEN. O recuso à descrição etnográfica 
exigiu explorar as cenas e a memória do lugar por meio dos relatos dos sujeitos, de pesquisa antes de adoecerem e da descrição da observação do pesquisador no diário de campo. Utilizamos também como técnica a entrevista narrativa com cinco informantes-chave atendidos no ambulatório do Centro de Referência em Saúde do Trabalhador (CEREST) do município. A escolha dos homens participantes do estudo se deu pela identificação dos técnicos do serviço, como bons interlocutores, e da busca dos prontuários pelo pesquisador.

A perspectiva teórica aqui adotada se alinha com o que Minayo (2010) chama de hermenêutica dialética, que integra uma interlocução com a hermenêutica de Gadamer, enquanto:

[...] busca da compreensão de sentidos, que se dá na comunicação entre indivíduos, baseando-se na experiência cultural e nas análises dos contextos e da práxis' e com a dialética, tomada como a 'ciência e arte do diálogo, da pergunta e da controvérsia, buscando nos fatos, na linguagem, nos símbolos e na cultura, os núcleos obscuros e contraditórios para realizar uma crítica informada sobre eles. (MINAYO, 2010, p. 166-167)

O posicionamento da autora quanto à complementariedade da hermenêutica e da dialética, enquanto "momentos necessários da produção de racionalidade em relação aos processos sociais e, por conseguinte, em relação aos processos de saúde e doença”, amplia o recurso à hermenêutica, em direção ao "entendimento dos textos, dos fatos históricos, da cotidianidade e da realidade", recorrendo no processo interpretativo ao método dialético, que, "por sua vez, ao sublinhar o dissenso, a mudança e os macroprocessos, pode ser fartamente beneficiado pelo movimento hermenêutico que enfatiza o acordo e a importância da cotidianidade”. (MINAYO, 2010, p. 349)

A pesquisa observou as implicações éticas e obedeceu aos aspectos éticos constantes na resolução 196/96 do Conselho Nacional de Saúde (CNS). As identidades dos sujeitos e da empresa foram ocultadas a fim de garantir o anonimato e a confidencialidade, portanto, os nomes apresentados dos informantes-chave e da empresa são nomes fictícios nomeados pelos pesquisadores. O projeto foi submetido ao Comitê de Ética em Pesquisa (CEP) da Escola de Enfermagem da Universidade Federal da Bahia (EEUFBA) sob o número 182.876 e foi aprovado. 


\section{O contexto de implantação do complexo automotivo}

A implantação do CIEN em Camaçari obedeceu à lógica de incremento da produção de veículos para o mercado interno e exportação para países da América Latina e está ancorada no signo da reestruturação produtiva mundial. Com a necessidade de reduzir os custos da produção, as indústrias automotivas têm migrado para países periféricos e para regiões periféricas nesses países.

De acordo com Gomes (2012), nos últimos anos ocorreu um processo de descentralização geográfica do setor automotivo, sendo que até a década de 1990, a maior parte das montadoras se encontrava na região do ABC Paulista, e hoje veículos automotores são fabricados em diversas regiões do país, com destaque para a Bahia onde a fábrica da empresa no município sede é responsável pela montagem de cerca de $10 \%$ dos veículos nacionais. Esse processo de interiorização ainda em curso do setor automotivo, com previsão de novas fábricas para Bahia e Pernambuco, é reflexo das constantes reestruturações produtivas vividas pelo setor após a crise do Fordismo na década de 1980, que obrigou a chegada de fábricas ao país e das diversas movimentações do governo brasileiro para expandir a indústria automobilística no país.

O complexo iniciou suas atividades oficialmente em outubro de 2001, modificando de forma profunda a estrutura socioeconômica do município sede. Parte dessa mudança se deu principalmente no setor de serviços pelo fato de que no acordo para a instalação da fábrica foi exigido contratação de mão de obra local. Tânia Franco (2009) descreve que a mão de obra empregada é composta por 79\% de residentes em município sede e Dias D’Ávila e por apenas $17 \%$ de residentes em Salvador, possibilitando com esse novo cenário uma nova urbanização desse município.

Ainda que o município sede tenha vivido um importante processo de industrialização no passado, os elementos da reestruturação produtiva e o lugar em que os trabalhadores "não especializados" cumpriam nesse processo produtivo são elementos que viabilizam a construção do imaginário do CIEN como um novo ciclo de possibilidades para os trabalhadores da cidade.

Sobre esse aspecto Minayo (2004) corrobora ao analisar as expectativas pela implantação de uma mineradora no estado de Minas Gerais e o processo de vinculação de trabalhadores não especializados à empresa. A autora destaca que entre as expectativas coletivas dos trabalhadores "braçais" contratados na implantação da mineradora estava que a empresa seria a "mãe", 
a "salvadora" ou a "promotora do progresso", mostrando que o processo de implantação de grandes empresas em pequenas cidades trazem processos comuns de criação de expectativa na população trabalhadora.

\section{O sonho metalúrgico: a chegada}

Na época da chegada do CIEN ao município sede, a maior parte da população economicamente ativa se encontrava trabalhando na indústria, sendo que a maior parte estava inserida na indústria química. Druck (1995) revela que a indústria petroquímica instalada em município sede empregou poucos trabalhadores da região, quadro que vai se acentuar com o processo de reestruturação produtiva vivido pelo setor, restando para a maioria dos trabalhadores a precarização do trabalho nas empresas terceirizadas. No final da década de 1990, a situação do emprego na região metropolitana de Salvador era bastante preocupante, o que serviu de estímulo para a disputa travada com o estado do Rio Grande do Sul pela instalação do complexo automotivo no município sede. A política de contratação de trabalhadores da região era a oportunidade dos antigos operários que estavam nas terceirizações do polo petroquímico, na construção civil ou para os jovens que estavam no setor de comércio e serviços poderem se inserir no setor industrial em busca de melhores salários, reconhecimento social e melhores condições de vida.

Quando eu comecei o curso [treinamento para entrar no CIEN], o que eu queria eram as vantagens, plano de saúde, salário certinho, participação em resultado. Era isso que a gente imaginava [...]. (Hugo)

A fala de Hugo é reveladora das expectativas existentes para a entrada no novo mundo que se abria na cidade de Camaçari. Jovens como ele, que estavam em outros setores, poderiam ser absorvidos pela indústria, não mais na condição de terceirizados e precarizados, mas trabalhando para uma empresa mundialmente conhecida. Seriam operários da empresa principal e usufruiriam de todos os benefícios que essa condição oferecia.

É o seguinte: ser metalúrgico foi a vinda da EMPRESA pra cá, aí surgiu aquela especulação, todo mundo tinha vontade, um sonho de trabalhar numa empresa, numa montadora, que aqui no Nordeste foi a primeira [...]. (João) 
Ah, as pessoas fora, ave Maria, era o sonho de todo mundo. A gente achava que como era uma empresa mundialmente conhecida, que ela é americana, a gente achava que ia ganhar dinheiro, que o serviço, a qualidade ia ser diferente do que eu já vi por aí a fora [...]. (Júlio)

Júlio e João confirmam o que foi dito por Hugo, as expectativas eram de ir para uma grande empresa e ter um emprego diferente dos anteriores, a oportunidade de mudar de vida, realizar os sonhos. Minayo (2004) encontra situação parecida sobre o processo de instalação de um setor produtivo em uma localidade formada por trabalhadores em precárias condições, mas gerando na região uma expectativa de mudança de vida e de aquisição de novos saberes.

Borges (2007), discutindo as transformações no mercado de trabalho brasileiro, destaca que o que observamos no município sede - precarização e terceirização no setor industrial - “[...] foram puxadas pela retração do emprego industrial, pela acentuação da divisão sociotécnica do trabalho - que propicia o surgimento de novas atividades de serviço - e pelo intenso processo de terceirização [...]”. (BORGES, 2007, p. 91, grifo nosso) A autora destaca que esse processo leva a uma transferência de postos de trabalho do setor industrial para o de serviços. A observação dessas transformações é importante para percebermos a organização do trabalho na RMS e como a chegada do CIEN vai alterar o trabalho industrial na região.

Em que pese que o contexto do município sede seja diferenciado, pois na cidade já existia um grande polo industrial quando ocorreu a instalação do CIEN, a expectativa se deu pelo fato de uma boa parcela dos trabalhadores da região se encontrar em empresas terceirizadas no polo petroquímico, empregos informais, desempregados ou sem grandes perspectivas de crescimento profissional, caracterizando-se por uma inserção precária no mercado de trabalho à época da implantação do complexo.

Na época não tinha formatura boa, como hoje também não tenho uma formatura. Tenho apenas segundo grau e alguns cursos assim como esse que eu fiz de montagem da EMPRESA, tenho esse curso que eu fiz de vigilante. [...] Quando eu entrei, achava até que ia sair de lá formado em alguma coisa, eu até optei por montagem porque eu achei que ia trabalhar, se tivesse oportunidade, que ia montar um motor, aí eu achei que ia conhecer a parte mecânica... Achei que eu ia aprender, imaginei que eu ia aprender mais coisa, como eu fiz o 
curso de montagem, aí eu achei que chegar lá, ia trabalhar montando peça, ia botar assim um motor, ia desenvolver ali, ia saber cada peça o que ia fazer. [...] Eu fiquei achando que ia sair daqui como técnico. (Luiz)

A fala de Luiz revela o desejo por formação profissional que existia nos homens que entraram no processo produtivo do complexo automotivo. A falta do conhecimento sobre modo de produção da empresa, com especialização em poucas tarefas, orientada pelo modelo Taylorista, levava os trabalhadores a idealizarem um trabalho que permitiria a aquisição de saberes de tal complexidade que lhes permitiria montar e desmontar um carro, nos quais deixariam de ser um operário pouco qualificado para assumir um importante papel no processo produtivo metalúrgico.

O perfil desse trabalhador com baixa escolaridade e formação profissional revela a situação de vulnerabilidade que estava presente na implantação do CIEN. O sonho de entrada no complexo estava posto para as camadas populares da cidade, para aqueles trabalhadores que estavam inseridos em setores terceirizados no processo produtivo petroquímico, nos serviços ou em subempregos e que encontrou no setor automotivo a possibilidade de ter mais que um emprego, uma identidade profissional.

O sonho de entrada no complexo automotivo se concretizou para milhares de trabalhadores de município sede e região. Se no ano de 2000 o setor automotivo não representava nem $1 \%$ do estoque de empregos formais na cidade, em 2010 passou a representar cerca de 10\%, empregando aproximadamente 7.800 trabalhadores. (BRASIL, 2010) Nesse mesmo período, o município sede vivenciou um dos maiores crescimentos econômicos do estado da Bahia, saindo do número de 29.165 empregos formais para 76.411, sendo o setor automotivo um dos principais catalisadores desse crescimento. Empregos diretos, com a geração de empregos no setor e de forma indireta, com a criação de uma classe trabalhadora com maior poder de compra na cidade em que se passou a demandar mais oferta de produtos e serviços.

Franco (2009) discute o processo de chegada do CIEN, destacando o papel que essa implantação teria na inversão da lógica aplicada na industrialização no setor petroquímico. Os acordos para a implantação do CIEN buscavam destinar a inserção da maior parte da força de trabalho da produção com trabalhadores do município sede e região, buscando 
modificar o processo a que destinou os trabalhadores "especialistas" residentes em Salvador, os empregos diretos no polo petroquímico e os piores empregos nas terceirizadas para os residentes na região metropolitana de Salvador.

\section{A construção da identidade metalúrgica}

Você vê todo mundo azulzinho, fardado. Acho que a gente sentia orgulho. Eu tinha muito orgulho de trabalhar numa empresa como a multinacional [...]. (Júlio)

A implantação do CIEN, principalmente a partir do ano de 2002, com a planta em pleno funcionamento, propicia a formação na cidade de um grupo operário majoritariamente formado por homens moradores do município sede, com características parecidas, que ganha destaque por passar a trabalhar no complexo e desfrutar de salários bem acima dos recebidos em outros setores econômicos da cidade. Como já discutimos antes, passam a ser trabalhadores diretos de uma importante multinacional. A fala de Júlio revela um importante sentimento dos trabalhadores que estiveram à frente do processo de implantação e consolidação da planta em município sede. $\mathrm{O}$ orgulho metalúrgico passa a ser parte da construção da identidade de um grupo que aos poucos vai ganhando um reconhecimento social na cidade.

Chegando ao município sede, você sente a presença do CIEN, mesmo que você não veja a fábrica, que fica numa região industrial distante do centro da cidade. Não é incomum andar pela rua e ver trabalhadores com a farda do complexo, mesmo em horários distantes da passagem do roteiro (ônibus que levam os trabalhadores a fábrica). Não vi ninguém pela rua com a farda da principal petroquímica, mas do complexo, da rodoviária até chegar à unidade avistei vários trabalhadores. Acho que isso tem a ver com o reconhecimento social de ser trabalhador da EMPRESA na cidade [...]. (Diário de campo, 28 de março de 2012)

Dentre os elementos de constituição da identidade metalúrgica no município sede, a constituição da identidade de classe através do fortalecimento do sindicato é um fato marcante. Ismar Sena (2009) revela que, no momento da implantação do complexo automotivo, uma disputa sindical se deu entre representantes do Sindicato dos Metalúrgicos da Bahia ligados à 
CTB, e um grupo de sindicalistas ligados a Força Sindical de São Paulo, que tinham como objetivo a criação de um sindicato local no município sede. Dessa disputa nasce o Sindicato dos Metalúrgicos do município sede, ligado ao sindicato estadual e à CTB, que precisa dar respostas rápidas para a categoria metalúrgica.

Em 2003, os metalúrgicos do município sede vivenciam a primeira importante greve da categoria. Uma categoria jovem, sem experiência sindical, que se enfrenta com a direção da empresa com uma pauta de equiparação salarial com os salários da montadora no sudeste. Nesse momento, é possível perceber a conformação de uma identidade coletiva, de um sentimento de orgulho por ser da categoria metalúrgica no município sede, que é produzido através do movimento de luta dos trabalhadores por melhores salários e por mais reconhecimento da planta do município sede.

Sou metalúrgico, com muito orgulho, sou da Bahia, quem não queria?

Sou Baiano, sou cabra da peste, sou nordestino sou trabalhador não tenho nada de menino $[. .$.

Tem gente fazendo carro, lugar do pólo industrial, aqui tem especialista respeitado cheio de moral [...].

(Trecho de música escrita por um operário do CIEN na época da greve de 2003)

A letra da música, utilizada pelo sindicato até os dias atuais, revela a afirmação da metalurgia automotiva no município sede, a possibilidade de trabalhadores tidos como braçais produzirem carros, mostrando a disputa com a empresa, na qual não ser menino significa não aceitar as condições de trabalho dadas pelo CIEN, os baixos salários e o assédio que já estava claro no ano de 2003.

João Bosco Santos (2000) considera que a identidade social é a soma dos papéis assumidos pelos sujeitos, sendo o trabalho um importante espaço de produção de identidade social. $\mathrm{O}$ autor faz ainda uma importante discussão sobre o papel que o trabalho cumpre na conservação da identidade social e no sentimento de pertença dos indivíduos. No município sede, é latente esse sentimento de pertença, o orgulho que os metalúrgicos possuem por estarem num emprego desejado por muitos, que o trecho da música faz questão de ressaltar, “quem não queria?”. 


\section{Satisfação e impacto econômico e social do trabalhar no CIEN}

Esse processo de consolidação de uma nova identidade na cidade de município sede, a partir da constituição de uma nova classe trabalhadora, é mediado por uma perceptível ascensão social desses trabalhadores. A fábrica permitiu que centenas de trabalhadores comprassem casa, carro, mantivessem filhos em escolas particulares, mudando a vida de uma parcela de trabalhadores do município sede.

Tenho dois colegas que eram garis, coletadores de lixo mesmo, que hoje trabatham lá. Eles têm orgulho sim, porque eles saíram do nada, do quase nada, pra tudo, não é? Eu tenho um colega que antes ele falava assim: Hugo, eu morava na casa da minha sogra, eu passava humilhação e hoje eu tenho a minha casa e hoje a minha sogra tá morando comigo. Entendeu como reverteu a situação? [...] Entre trabalhar no comércio e trabalhar na EMPRESA, tem que trabalhar na EMPRESA! A diferença é muito grande, de salário mesmo, é o dobro do salário. Você vai ter esse diferencial. Fora essa questão de no final do ano a gente ter a participação em resultados, que hoje é quase dez mil reais. [...]. (Hugo)

A mudança trazida pelos novos salários, fornecimento de plano de saúde e ganho de PLR $^{3}$ proporciona aos trabalhadores a realização de planos nunca antes imaginados. Cria na cidade um conjunto de trabalhadores com maior poder aquisitivo, movimenta o comércio local, gera um novo ciclo de crescimento. $\mathrm{O}$ trecho acima revela como a mudança no reconhecimento social se dá no cotidiano, no qual trabalhadores que estavam nas piores inserções no mercado de trabalho passam a compor a força de trabalho de um novo setor, mudando por completo a sua vida.

Para além dos impactos financeiros relatados por nossos informantes, a identidade social dos metalúrgicos do município sede também se constitui pelo sentimento de pertença a uma categoria consolidada. Ainda que não seja um petroleiro, emprego sonhado por muitos no estado da Bahia, ser parte da categoria metalúrgica, trabalhar no CIEN, representa um diferencial para o restante dos trabalhadores da cidade e da região, incluindo esses homens no mundo do trabalho não apenas na cidade, eles passam agora a ser reconheci-

3 Participação nos Lucros e Rendimentos. 
dos como trabalhadores de uma empresa que tem plantas em vários lugares do mundo, passam então a ter uma importância antes não imaginada.

Rapaz, na verdade. A gente sente até um prazer de trabalhar numa empresa de grande porte como é a EMPRESA, ou uma parceira, certo? Na questão do salário, não é ruim. Se eu disser a você que é ruim, eu estou mentido pra você. Tem a questão do plano de saúde, que ajuda você a fazer uma cirurgia, como eu já fiz duas. Se eu não tivesse plano, não poderia ter feito. Questão da vida social, econômica, que melhora um pouco. Tem a PL (participação nos lucros) que com muita luta a gente conseguiu, o sindicato conseguiu [...]. (Júlio)

Dados do DIEESE mostram que na implantação do CIEN, o salário médio de um trabalhador da produção era cerca de três vezes menor que a média na região do ABC Paulista. Em 2005, mesmo com um aumento significativo da remuneração média no município sede, que sai de $\mathrm{R} \$$ 608,36 em 2001 para $\mathrm{R} \$ 1.297,93$ em 2005, ainda há um grande abismo entre os salários do CIEN e dos trabalhadores da empresa em São Paulo. $\mathrm{O}$ estudo comenta ainda que a justificativa das empresas para que o salário no município sede seja menor é devido ao menor custo de vida. O que não se confirma, pois, em pesquisa realizada sobre os custos e poder de compra dos trabalhadores, observou-se que não existem diferenças significativas entre os custos de vida das regiões de produção automotiva que justifiquem uma discrepância salarial como a existente. (DIEESE, 2003, 2007)

Fato é que o ingresso no CIEN transforma a vida dos trabalhadores do município sede, levando-os a experimentarem sensações de satisfação no trabalho durante muito tempo, pelo potencial transformador social que o trabalho passa a mediar.

Eu gostava pelos meus colegas, assim, a gente criou aquele vínculo de amizade. Era um sofrimento, mas tinha alegria. [...]. (João)

Eu era uma pessoa dedicada, gostava de fazer mesmo nessa operação, gostava de trabalhar ali. Eu me sentia orgulhoso quando eles diziam que era o operador, melhor operador de painel, mesmo sofrendo, mesmo com aquelas dificuldades, mas eu me sentia orgulhoso de ser [...]. (João)

A fala de João revela dois componentes do trabalho promotor de satisfação. A relação com os colegas de trabalho, que ajuda a criar no indivíduo 
uma identidade social e o prazer pelo reconhecimento social do seu trabalho e da sua utilidade são elementos potenciais do trabalho na transformação da vida dos sujeitos. Mesmo em situações de adversidade no trabalho, as características de satisfação também estão presentes e elas parecem se configurar como importantes fatores de apoio para se manter trabalhando mesmo em face de adversidades.

Eu tenho orgulho de ser empregado, porque é disso que a gente sobrevive. Mas esse orgulho de ser metalúrgico é só ficção. Quando você cai na realidade, você vê que o negócio não é bem isso que a gente pensa [...]. (João)

O enunciado apresenta uma importante contradição do mundo do trabalho. O mesmo trabalho que produz identidade, que tem um componente de satisfação, também carrega adoecimento, desconstrução de identidade e de sofrimento. Ao entrar na fábrica, os operários começam a perceber que a realidade era mais dura do que os sonhos e expectativas que conseguiam pensar.

Ninguém imagina que vai encontrar o ambiente ora insalubre, ora maléfico para a saúde, seja ergonomicamente ou psicologicamente, porque (suspiro) o que acontece lá dentro, se você for observar, se você tiver a oportunidade de entrar na empresa, você vai ver um monte de loucos trabalhando, eles não param, não param para nada. É, sai uma peça de um lado, já está entrando outra. A rotatividade é intensa. Tem um ritmo frenético. (Hugo)

O processo produtivo é marcado pela intensidade, na qual os ritmos da produção são incompatíveis com a capacidade do corpo. Tânia Franco (2011) discute a problemática dos processos produtivos, no qual os "tempos sociais” - tempos engendrados pelo ritmo do capital - não são compatíveis com os “tempos naturais" - tempos biopsicossociais. Esse ritmo de trabalho determinado pela linha de produção, que não para, que é frenético, adoecedor, é fruto de um processo produtivo com que se combina características de controle excessivo dos tempos e movimentos de uma produção acelerada para acompanhar os ritmos do mercado.

É muita pressão, muito foco, pouca valorização, pouca importância com a saúde do funcionário. O foco era produção, produção, produção e não esquecendo que pra isso acontecer teria que ter um funcionário para poder tra- 
balhar e produzir [...]. A gente fabricava era quatrocentos carros no turno, trezentos ou quatrocentos carros no turno. Imagine você trabalhar oito, nove horas de trabalho, fazendo aquela mesma coisa, escutando aquela mesma coisa [...]. (João)

Esse modelo produtivo que, de acordo com Ricardo Antunes (2002), combina características de gestão do trabalho típicas do Taylorismo/ Fordismo associadas com a especialização flexível toyotista, permitindo impor uma maior velocidade à produção, tem sido responsável por um importante impacto no perfil de adoecimento dos trabalhadores no município sede.

Os dados da unidade de saúde reforçam essa ideia. Há evolução da procura por atendimento na unidade de saúde do trabalhador do município sede no período de 2003 a 2011. Comparando os dados com o estudo de Silva (2002), observa-se que, após a implantação do CIEN, a procura pelo serviço passou a aumentar, tendo como ápice os anos de 2005, 2006 e 2007. Os dados ainda revelam que de toda a demanda atendida no período referido na unidade, $18,2 \%$ foi gerada por trabalhadores do setor automotivo, sendo a maioria homens com idade de até 40 anos.

É importante destacar que, a partir de 2008, há um descenso no número de trabalhadores do CIEN atendidos no CEREST. As evidências encontradas não apontam para um descenso causado pela melhoria das condições de trabalho no CIEN e sim pela mudança na política de reconhecimento de benefícios pela previdência social. Com a constituição do Nexo Técnico Epidemiológico Previdenciário em 2007, o número de trabalhadores que procuram o CEREST diminui. Essa diminuição pode ser explicada pelo fim da exigência de possuir uma Comunicação de Acidentes de Trabalho (CAT) para ter acesso à concessão de auxílio doença-acidentário (B91) pela previdência social. (CODO, 2010)

Ao observarmos essa evolução no período, é possível notar que há um acúmulo de trabalhadores buscando o serviço de saúde com pouco tempo de trabalho, o que pode ser explicado pelo processo de trabalho desgastante, pela forma de implantação do complexo, que iniciou a produção com baixo número de operários, com estrutura sem adequação às necessidades de saúde, fazendo com que os metalúrgicos utilizassem do corpo como auxiliar do processo produtivo. Mais que operar máquinas, eles precisavam em alguns momentos substituí-las. 
Esses homens, que em comum possuem o fato de terem participado da implantação e do desenvolvimento inicial da indústria automotiva na Bahia, vivenciaram um processo produtivo marcado pela disputa de mercados e consolidação da produção. Os altos investimentos realizados para a instalação da empresa precisariam retornar rapidamente e por isso o aumento da produção com destinação ao mercado interno e às exportações fixavam para os trabalhadores um trabalho acelerado, no qual o ritmo da linha de produção era quem ditava as ordens, as quais os trabalhadores usavam de si para dar conta do processo produtivo.

\section{"A gente fazia tudo aquilo manual": Usos de si para dar conta do processo produtivo}

Ela deve ter uns nove a dez quilos e a gente manuseava. Na época não tinha os dispositivos pra retirar, para pegar uma peça e a gente fazia tudo aquilo manual. Para você ter uma ideia, eu tirava da esteira três peças por hora [...]. Associado a isso tinha peças que eu tinha que retirar que a gente mandava pra Venezuela [...] Então, isso todos os dias. [...] E eu trabalhei dez meses seguidos em uma única operação [...]. (Hugo)

O cotidiano do trabalho, no início da produção do CIEN, foi marcado pela sobrecarga, horas extras, falta de equipamentos que levavam os trabalhadores a usarem do seu corpo para dar conta das demandas da produção. O que estava em jogo para esses trabalhadores era a necessidade de se mostrar produtivo, mesmo que para isso precisassem levar o corpo ao limite, trabalhar sob o ritmo das máquinas, muitas vezes substituindo-as.

Só que o nosso manipulador da empresa não era igual ao da parceira lá não. Lá era manual mesmo, o sistema de ar comprimido despressurizava com você como painel na mão. Era muita força que você tinha que usar. E aí você recebia aquele peso todo e você tinha que segurar. E aí fazer o jogo assim pra jogar pra dentro do carro. E aí era um carro atrás do outro. [...] E aí, meu irmão, era o tempo todo assim. Agora você me responda: tem condições de um ser humano aguentar um negócio desse e dizer que não sente nada? [...]. (João)

O setor da montagem final no CIEN é marcado pelo ritmo acelerado de trabalho, no qual a linha de produção dá o ritmo do trabalho, que deve ser o mais intenso para dar conta da alta produtividade da planta, e, na maior 
parte das vezes, os tempos da produção não correspondem às necessidades impostas pela tarefa prescrita, fazendo o trabalhador usar de si para dar conta da tarefa. A contradição colocada é que mesmo estando presente no ambiente, o que Ive Clot (2001) chama de atividade impedida, os trabalhadores "se viram" para se manter no emprego, e vão dando conta até que o corpo não suporte mais a pressão da produção. Para esse autor:

O real da atividade é também o que não se faz, aquilo que não se pode fazer, o que se tenta sem conseguir - os fracassos - aquilo que se desejaria ou poderia fazer, aquilo que não se faz mais, aquilo que se pensa ou sonha poder fazer em outro momento. [...] Atividade é aquilo que se faz para não se fazer o que tem que ser feito ou ainda o que se faz sem desejar fazer. (CLOT, 2001, p. 6)

Nesse sentido, ao analisarmos a atividade relatada pelos operadores na linha de produção, podemos perceber as reinvenções cotidianas que esses trabalhadores precisam fazer para dar conta "do que deve ser feito" num ambiente totalmente contraditório.

De um lado a tarefa prescrita - montar o painel do carro em um tempo definido - do outro a velocidade da linha de produção, a falta de equipamentos e os riscos de parar a linha, acumular carros na montagem ou deixar peças caírem do manipulador, o que recairia sobre o trabalhador, que "é lento", ou que "emperra a produção" como relatou Luiz, ou ainda que é "lerdo" e deixa as peças caírem do manipulador”, medo enfrentado por João. Os discursos elucidam o que Ive Clot (2001) chama de disponibilidade psíquica cada vez maior que impele os trabalhadores a colocarem cada vez mais de si no trabalho.

Na fala do operador, ele mostra a contradição entre o prescrito e o real no trabalho, entre todos os rearranjos que ele precisa fazer deliberadamente para dar conta da atividade. Fica claro que o início do processo produtivo no complexo foi marcado pela necessidade constante de uso de si pelos trabalhadores para a atividade que se impunha.

As escolhas feitas pelos trabalhadores para se manterem produtivos, $\mathrm{e}$ nos empregos no momento de alta competitividade no complexo, mostra que estas escolhas têm levado a situações de sofrimento e, infelizmente, apesar de chamarmos esse processo de escolhas, outras alternativas não são dadas aos trabalhadores que precisam "se virar" no cotidiano para cumprir as tarefas. Sobre isso Ive Clot (2001, p. 5) diz que "[...] é uma ati- 
vidade contrariada, um desenvolvimento impedido. É uma amputação do poder de agir”.

Porque é um esforço repetitivo, porque você anda o dia todo de ré. Têm retrovisores, mas a segurança não queria que olhasse só o retrovisor porque às vezes você olhava de um lado e o pedestre já tava do outro lado e você num via. (Júlio)

Para você ir ao banheiro você tinha que ver alguém, que a linha num para, a linha num para, vocêficava apertado pra ir ao banheiro [...] Porque acham que você tem que ficar o mínimo possível no banheiro, ir correndo e voltar correndo. [...] Às vezes vocêfica uma hora, duas horas pedindo pra ir ao banheiro e nada de ninguém chegar e dizer, ah, vou tirar o seu banheiro. Já aconteceu de ter gente de parar a linha de produção. Eu já parei a linha de produção pra ir ao banheiro [...]. (João)

Nota-se nas falas dos trabalhadores que o seu poder de agir é tolhido pela organização do trabalho, em que a atividade fim é impedida, bem como os desejos de fazer "bem feito" são repensados a todo o momento. O trabalhador precisa fazer escolhas e faz usando mais de si, do seu corpo, da sua saúde, não fazendo pausas, forçando o uso de um segmento do corpo, dirigindo em posição desconfortável ou tantas outras situações encontradas no cotidiano do processo de trabalho. Podemos compreender essa situação, a partir de Ive Clot (2001), como uma “atividade envenenada” pela diminuição dos trabalhadores.

Quando se observa o trabalho real, vê-se que esse é totalmente diferente do prescrito, pois a partir da observação das modulações realizadas percebe-se que não daria conta de atingir os objetivos traçados.

Olhar apenas para o realizado jamais nos daria dimensão da "luta cotidiana" que travam esses operadores. Aqui fica claro que o realizado não possui o monopólio do real, e que esse real é muito maior do que podemos imaginar, e ele é elaborado cotidianamente pelos trabalhadores que precisam fazer suas escolhas.

É certo que essas escolhas, neste contexto, trazem diversas consequências para esses trabalhadores como o adoecimento físico, a sensação de fracasso, a hipersolicitação constante. O uso do si desse "destino a ser vivido" tem seu preço. Ive Clot (2001, p. 6) diz que

A fadiga, o desgaste violento, o estresse se compreende tanto por aquilo que os trabalhadores não podem fazer, quanto por aquilo que eles fazem. As atividades suspensas, contrariadas ou im- 
pedidas, e mesmo as contra- atividades, devem ser admitidas na análise assim como as atividades improvisadas ou antecipadas. A atividade removida, oculta ou paralisada não está ausente da vida do trabalho. A inatividade imposta - ou aquela que o trabalhador se impõe-pesa com todo o seu peso na atividade concreta.

Os usos de si explica o fenômeno do adoecimento tão precoce nessa população de trabalhadores do setor automotivo. A combinação de elementos como a organização do trabalho e as condições nas quais esse trabalho é desenvolvido levou centenas de trabalhadores do complexo automotivo a procurarem os serviços de saúde. É possível perceber a partir das narrativas desses trabalhadores que aquilo que se faz - movimentos repetitivos, posturas anômalas, hipersolicitação do corpo - está tão relacionado com o adoecimento quanto o que não se pode fazer - não se pode realizar como se deseja, não pode se permitir pausas, não se pode ajustar o prescrito, não se pode fazer o que se tinha vontade etc. -, reforçando a tese que os processos de adoecimento são construídos no cotidiano, nas contradições de um trabalho vivo, em que a todo momento coloca sobre os trabalhadores a decisão entre o possível e o impossível. Observamos surgir o sofrimento e o adoecimento no trabalho em constante conflito com o orgulho metalúrgico e o prazer no trabalho.

Ela quer quantidade de carro, no final do turno atingir a meta e acabou [...]. Resumindo: "Você lá é um parafuso a mais. Aluiu, joga fora e bota outro [...]. (João)

Os conflitos gerados pelo processo de trabalho que leva centenas de trabalhadores a adoecerem, faz com que estes passem a se perceber como uma parte descartável do processo de trabalho, usados apenas para compor a grandiosa engrenagem produtiva e lança-los fora a qualquer tempo em que não sirvam mais para o processo produtivo. Nesse momento, passa a compor esse cenário um forte sentimento de não pertencimento, aprofunda-se o estranhamento no trabalho, pois agora confirmando o que disse Marx (2006, p. 82): "quanto mais [...] cria, mais [se torna indigno e sem valor], quanto mais bem formado seu produto, [...] mais deformado ele fica”.

$\mathrm{O}$ adoecimento na fábrica permite, por um momento, que o trabalhador deixe apenas de pensar no trabalho, passe a se ver no processo e inclusive a questionar o processo. Questiona, ao passo que compreende a lógica de fun- 
cionamento do capital, percebe que seu trabalho foi apropriado por outro, sua força de trabalho foi usada até o esgotamento e que agora ele está desamparado.

O problema é que se exige muito e devolve-se pouco, como sempre foi a relação patrão-empregado [...] A empresa na minha opinião, eu posso estar errado também, pode ser de certa forma, que eles se preocupem de alguma forma com quem tá fora, mas nunca me perguntaram nada, nem se eu estava bem, mal, nem se eu precisei nada. (Hugo)

É possível perceber como as contradições capital-trabalho se expressam no cotidiano e são despercebidas para muitos trabalhadores, ou são compensadas por recompensas de um salário acima da média da cidade, ou por ganhos com a Participação nos Lucros e Rendimentos (PLR). Para os trabalhadores que adoeceram no trabalho, elas ganham um contorno mais claro, pois há uma real percepção de que foi da dualidade entre capital-trabalho, homem-máquina, patrão-empregado que se determinou seu adoecimento. Os trabalhadores sentem "na pele" o produto da lógica capitalista, como diz Harvey (1992), se apoiam na extensão da jornada de trabalho, na transferência de capitais de regiões de altos salários para regiões com baixos salários, mudança organizacional e tecnológica, utilizando-se de trabalhadores de lugares em desenvolvimento onde existe ausência de contrato social com o trabalho ou onde esses contratos têm pouca força.

Dessa forma de produção, na qual os trabalhadores são vistos como mais uma peça do processo produtivo, da qual é possível adaptar a qualquer momento para novas formas de organização do trabalho, surgem situações que produzem iniquidades em saúde. $\mathrm{O}$ adoecimento no complexo automotivo é mediado pelo processo produtivo e pelas condições socioeconômicas dos trabalhadores, que não permitem que os mesmos abandonem o processo produtivo, mesmo quando percebem que estão adoecendo no trabalho. Somado a isso, a ausência do Estado na proteção do trabalhador, ao tempo que é presente na garantia das condições de produção para as empresas, aprofundam essas desigualdades, pois em grande medida abandona os trabalhadores à própria sorte, deixando-os perdidos em busca de reparação social pelas perdas que tiveram.

O que mais me incomoda é a desatenção que a gente tem por parte da empresa e por parte dos órgãos competentes [...] É uma desatenção total do Ministério do 
Trabalho, de não se preocupar mesmo. Parece que a gente busca a doença. Não é assim. [...] Cadê o interesse da empresa no trabalhador. Eu não sou funcionário da empresa? [...] Essa inércia do Estado com a nossa situação é que me incomoda. [...] O que será que o ministério do trabalho não está enxergando? O que será que o CREMEB não observa esses lesionados? A própria justiça do trabalho, não é mais imperativa com essa empresa? Qual o prejuízo que a sociedade vai ter daqui a mais de dez anos, com esse bando de lesionados dependendo de benefícios de INSS? (Hugo)

As narrativas revelam o desespero de trabalhadores que entraram sadios no processo de trabalho, viveram a fábrica na máxima intensidade, doaram-se na busca de construir um sonho. A percepção de que a empresa está “virando as costas" para eles e de que o Estado é omisso, só amplia a magnitude do problema vivenciado pelos trabalhadores, que começam a perceber e questionar o porquê do Estado não se mostrar mais presente, não usa da mesma força que usou para beneficiar a empresa na época da implantação, agora para ajudar os trabalhadores.

Hugo questionou o que, para Harvey (2008), nada mais é do que o papel previsto do Estado neoliberal. Em caso de conflito, tende a ficar favorável ao capital em detrimento dos direitos - e da qualidade de vida - dos coletivos de trabalhadores. A esse novo Estado é dada a função de manter a "integridade do sistema financeiro e a solvência das instituições financeiras e não o bem-estar da população ou a qualidade ambiental”. (HARVEY, 2008, p. 81) É em meio a esses conflitos entre capital e trabalho que se expressam as experiências dos trabalhadores com seus empregadores ou com o Estado. Os trabalhadores com LER/DORT vão experimentando a perda da capacidade para o trabalho e sentindo-se cada vez mais desamparados.

Se o tempo voltasse, fazia tudo diferente. Eu ajudei muito a empresa, hoje em dia não estou sendo ajudado. (Ubaldo)

O processo vivenciado pelos trabalhadores do complexo automotivo do município sede traz em si percepções contraditórias ao tempo em que ser trabalhador do CIEN era motivo de orgulho, sendo esse processo responsável pela formação de uma identidade coletiva, mas também por um duro processo de adoecimento que desconstrói, os traços de uma identidade coletiva construída. $\mathrm{O}$ adoecimento e incapacitação são mediados diretamente pelo modelo de produção capitalista, pela organização do processo produtivo, que 
reúne um hibridismo organizativo com características do modelo taylorista-fordista, somadas às características da acumulação flexível, que, em se tratando de uma cidade em uma das regiões menos desenvolvidas de um país periférico, ganha contornos ainda mais danosos para o trabalho.

Mediado ainda por um Estado que se distingue por características neoliberais, ausente na proteção do bem estar da população e presente para o grande capital, o processo de adoecimento acontece isolando os trabalhadores, que passam a ser o "peso morto" no trabalho, os queixosos, os que só querem reparação, os que incomodam a empresa e o Estado na busca por justiça social. Destaca-se ainda nesse processo a ausência da pauta da saúde dos trabalhadores com centralidade na intervenção sindical. A centralidade da luta por salários e a não priorização da luta contra o adoecimento no trabalho são elementos que explicam a situação em que se encontram os trabalhadores do complexo. É nesse contexto que os sonhos vão sendo desconstruídos. Os trabalhadores passam a perceber que o sonho metalúrgico ficou para trás, que passa a ser um não orgulho marcado pelo abandono da empresa e do Estado. Materializa-se então o sentimento de homens descartáveis, parafusos, máquinas, que ao se detectar um defeito devem ser substituídos por outros, para que assim, com novas peças prontas para uso, a produção continue. Ainda que o preço disso seja cada vez mais homens adoecidos, incapacitados e com sonhos interrompidos.

\section{Referências}

ANTUNES, R. Adeus ao Trabalho? ensaio sobre as metamorfoses e a centralidade do mundo do trabalho. 8. ed. São Paulo: Cortez: UNICAMP, 2002.

BORGES, A. Mercado de trabalho: mais de uma década de precarização. In: DRUCK, M. G.; FRANCO, T. (Org.). A perda da razão social do trabalho: terceirização e precarização. São Paulo: Boitempo, 2007.

BRASIL. Ministério da Previdência Social. Anuário Estatístico da Previdência Social 2010. 2011. Disponível em: <http://www.mps.gov.br/arquivos/ compressed/3_111007-155436-292.zip >. Acesso em: 31 out. 2011. Seção IV Acidentes do Trabalho.

BRASIL. Ministério do Trabalho e Emprego. Relatório Anual de Informações Sociais. Brasília, DF, 2010. 
CLOT, Y. Clínica do trabalho, clínica do real. Tradução de Kátia Santorum e Suyanna Linhales Barker. Le Journal dês psychologues, Paris, n. 185, mar. 2001.

CODO, W. Uma revolução silenciosa em saúde e trabalho no Brasil. In:

MACHADO, J. M. H.; SORATTO, L.; CODO, W. (Org.). Saúde e Trabalho no Brasil: uma revolução silenciosa: o NTEP e a Previdência Social. Petrópolis, RJ: Vozes, 2010. p. 12-19.

CONLUTAS. Homenagem aos metalúrgicos. 2008. Disponível em: <http:// cspconlutasbahia.blogspot.com.br/20o8/10/homenagem-aos-metalrgicos.html>. Acesso em: 15 jan. 2013 .

DIEESE. Sindicato dos Metalúrgicos do ABC. Do holerite às compras: remuneração, preços e poder aquisitivo do tempo de trabalho em 17 municípios com produção automobilística no Brasil. São Paulo, 2003.

DIEESE. Sindicato dos Metalúrgicos do ABC. Do salário às compras: remuneração, preços e poder aquisitivo do tempo de trabalho em 54 municípios com produção automobilística, siderúrgica e autopeças. São Paulo, 2007.

DRUCK, M. G. Terceirização: (des)fordizando a fábrica: um estudo do complexo petroquímico da Bahia. 1995. 271 f. Tese (Doutorado em Ciências Sociais) Instituto de Filosofia e Ciências Humanas, Universidade Estadual de Campinas, 1995 .

FEDERAÇÃO DAS INDÚSTRIAS DO ESTADO DA BAHIA - FIEB. Pesquisa Industrial Anual (PIA) - 2008 (sinopse). Salvador, 2010.

FORD MOTOR COMPANY. Camaçari-BA. [201-]. Disponível em: <https://www. ford.com.br/sobre-a-ford/fabricas-no-brasil/camacari/>. Acesso em: 20 fev. 2013.

FRANCO, A. Em tempos globais, um “novo” local: a Ford na Bahia. Caderno CRH, Salvador, v. 22, n. 56, p. 359-38o, maio/ago. 2009.

FRANCO, T. Alienação do trabalho: despertencimento social e desrenraizamento em relação à natureza. Caderno $C R H$, Salvador, v. 24, p. 171-191, 2011. Suplemento 1.

GOMES, R. A. Indústria automobilística como um setor-chave na estrutura produtiva de uma região: o caso do Complexo FORD de Camaçari. 2012. 85 f. Dissertação (Mestrado em Gestão Logística) - Centro de Tecnologia, Universidade Federal do Ceará, Fortaleza, 2012.

HARVEY, D. A condição pós-moderna: uma pesquisa sobre as origens da mudança cultural. São Paulo: Loyola, 1992. p. 117-184.

HARVEY, D. O neoliberalismo: história e implicações. Tradução de Adail Sobral e Maria Stela Gonçalves. São Paulo: Loyola, 2008. 
INSTITUTO BRASILEIRO DE GEOGRAFIA E ESTATÍSTICA - IBGE. Censo 2010. [2010]. Disponível em: <http://www.censo2010.ibge.gov.br/>. Acesso em: 20 fev. 2013 .

MARX, K. Manuscritos econômico-filosóficos. Tradução de Jesus Ranieri. São Paulo: Boitempo, 2006.

MINAYO, M. C. S. De Ferro e Flexíveis: marcas do estado empresário e da privatização na subjetividade operária. Rio de Janeiro: Garamond, 2004.

MINAYO, M. C. S. O desafio do conhecimento: pesquisa qualitativa em saúde. 12. ed. São Paulo: Hucitec, 2010.

SALERNO, M. S; MARX, R.; ZILBOVICIUS, M. A nova configuração da cadeia de fornecimento na indústria automobilística no Brasil. Revista de Administração, São Paulo, v. 38, n.3, p. 1-1, jul./set. 2003 .

SANTOS, J. B. F. O avesso da maldição do Gênesis: a saga de quem não tem trabalho. São Paulo: Annablume, 200o. p. 239-293.

SENA, I. N. Fábrica de lesões: trabalho, adoecimento e ação sindical no complexo automobilístico baiano. 2009. 139 f. Dissertação (Mestrado em Ciências Sociais) - Faculdade de Filosofia e Ciências Humanas, Universidade Federal da Bahia, Salvador, 20og.

SILVA, A. C. C. Estudo da demanda LER/DORT atendida na Unidade de Saúde do Trabalhador de Camaçari / USAT, no período de 1995-2001. 2002. 37 f. Monografia (Especialização em Saúde do Trabalhador) - Instituto de Saúde Coletiva, Universidade Federal da Bahia, Salvador, 2002. 


\title{
Confinamento em alto mar de militares da Marinha do Brasil e repercussões na qualidade de vida
}

\author{
ANA CAROLINA NASCIMENTO DE ALBUQUERQUE RAMOS \\ PAULO GILVANE LOPES PENA
}

\section{Introdução}

Na atualidade, o "mundo do trabalho" configura-se como um contexto de inúmeras transformações sociais, políticas e econômicas que, inevitavelmente, produzem reflexos no comportamento e relacionamento humano. No caso da Marinha do Brasil, instituição das Forças Armadas, além das peculiaridades da vida militar, a atividade profissional requer longos períodos em alto mar e o distanciamento da convivência social mais ampla, revelando um duplo desafio à promoção da qualidade de vida e saúde desses trabalhadores. Na literatura nacional, apesar de pouco extensa, as pesquisas revelam a importância do isolamento marítimo para o desenvolvimento de doenças e consequentes dispensas temporárias durante as atividades (SILVA; SANTANA, 2004), assim como enfermidades relacionadas à cultura institucional. (HALPERN; LEITE, 2011, 2013a, 2013b, 2014) 
O trabalho na Marinha tem suas especificidades históricas seculares diante da instituição militar. Sabe-se que o surgimento da Marinha Brasileira remonta à época do descobrimento do Brasil quando portugueses e franceses disputavam o poder das terras brasileiras. Nesse combate, indígenas se uniram aos portugueses, reforçando a esquadra com embarcações a remo. Além de ter sido a primeira defesa organizada contra uma invasão ao território brasileiro, o fato caracterizou-se como o nascedouro da Marinha do Brasil. (MARINHA DO BRASIL, 2013)

Desde então, tem como principal atividade a defesa da pátria e a garantia dos poderes constitucionais (BRASIL, 2005) organizada com base em uma hierarquia e disciplina, cujas bases ideológicas se confundem com a sua origem. A tripulação das embarcações realiza diversas operações de treinamento pessoal e exercícios no mar, existindo as operações de caráter real, como socorro e salvamento, patrulha naval, operações de paz da Organização das Nações Unidas (ONU), ações humanitárias, dentre outras.

Tais atividades requerem períodos de afastamento da vida social no continente, seja dos familiares, dos amigos ou de outras atividades como lazer e cultura. Quando o profissional parte para as operações no mar, passando dias e até meses afastando-se de outros ambientes sociais, permanece em uma situação de confinamento coletivo em alto mar. Cabe destacar que o confinamento a que nos referimos nesse estudo não se refere ao espaço da embarcação, mas trata-se do ambiente organizacional onde os trabalhadores levam uma vida fechada, sem acesso a outros ambientes sociais por um determinado período.

Para Goffman (1987), ambientes organizacionais nesses moldes, nos quais os trabalhadores levam uma vida fechada, com períodos prolongados de afastamento do resto da sociedade, podem induzir a um estado social de "destreinamento", quando os indivíduos apresentam um sentimento de "perda" dos papéis sociais em "terra”. A repercussão dessa situação na noção de qualidade de vida desses atores sociais, que é pulverizada no imaginário social como um objetivo a ser alcançado tanto a nível individual quanto organizacional, adquire contornos específicos em cada ambiente de trabalho, em função dos signos e significados compartilhados por cada cultura. Para Limongi-França (2004), a qualidade de vida no trabalho na sociedade pós-industrial envolve elementos como os vínculos e estrutura da vida pessoal, fatores socioeconômicos, metas empresarias e pressões or- 
ganizacionais. Já Minayo, Hartz e Buss (2000, p. 9) abordam a qualidade de vida numa visão mais ampla, menos economicista, acrescentando que "[...] em todas as sondagens feitas sobre qualidade de vida, valores não materiais, como amor, liberdade, solidariedade e inserção social, realização pessoal e felicidade, compõem sua concepção".

Na Marinha, as operações no mar, mesmo em tempos de paz, são consideradas um exercício de operação de guerra e não é permitida a tripulação o uso de aparelhos de telefonia móvel, mesmo que o navio esteja navegando próximo à costa e haja sinal para a comunicação. Esse uso é permitido somente ao comandante do navio, que pode antecipar a presença de "forças inimigas" e desenvolver planos de contingências para eliminar estas ameaças. Alguns navios da Marinha do Brasil possuem uma rede de comunicações que funcionam através do satélite e se limitam ao recebimento e envio de mensagens institucionais e telefonemas emergenciais. Todos esses cuidados fazem parte das orientações do Guia de Guerra Naval (2000) que determina a segurança das informações, para que a operação consiga êxito e o navio em guerra não seja detectado e atingido por seus inimigos.

Salienta-se que, no período de formação, os militares passam também por certo distanciamento da sociedade, pois tanto na Escola Naval, instituição formadora dos oficiais da Marinha, quanto nas Escolas de Aprendizes de Marinheiros, instituição formadora do corpo de praças da armada, os alunos permanecem em regime de internato durante toda a semana, sendo liberados somente aos finais de semana para realizar as atividades de lazer e ver a família. Como analisa Lins (2012, p. 20):

Os jovens entravam ainda muito cedo e ficavam muitas vezes longe de suas famílias, com rígidas regras disciplinares a serem cumpridas por todos em longos períodos de afastamento de uma vida externa, seja pelo confinamento no quartel, seja pelas viagens de instrução em que o oceano era único diálogo com o mundo externo. Pode-se dizer que viviam uma situação de expropriação de sua autonomia e de suas relações sociais mais amplas.

Nesse sentido, o estudo da qualidade de vida na marinha está condicionado às noções de distanciamento, isolamento e internamento tanto em navios como em terra. Essa pertinência estrutural se adiciona às características do modo de organização militar citados, como hierarquia e disciplina. O trabalho exerce uma posição central, e, dialeticamente, o trabalhador olha 
para “[...] o mundo a partir de uma janela, onde a profissão cria as cores e as nuances da paisagem da casa, do bairro, da vida associativa e dos projetos do futuro". (MINAYO; SOUZA, 2003, p. 293)

Portanto, o fio condutor da presente reflexão expressa a necessidade de se pensar e repensar uma proposta de intervenção que corrobore com a manutenção/promoção da saúde e qualidade de vida do trabalhador, sem deixar de considerar as especificidades dos sujeitos estudados, composta por militares da Marinha do Brasil. Procuramos compreender as repercussões na qualidade de vida dos militares e como esse tipo de trabalhador se configura no ambiente de trabalho e fora dele. A vida social aqui estudada é a maneira que o indivíduo interage com a sociedade, através das suas relações sociais e atividades desenvolvidas.

\section{Metodologia}

Utilizando técnicas da abordagem qualitativa, a investigação buscou descrever a complexidade do problema, especialmente na esfera subjetiva, apreendendo as características, propriedades ou relações existentes na realidade pesquisada, tendo como referência duas categorias: o isolamento e a reserva/aposentadoria militar. A produção dos dados se deu a partir da realização de entrevistas e da pesquisa documental na divisão de pessoal dos próprios navios. O conteúdo acumulado no diário de campo, assim como, o material produzido nas entrevistas, constituíram a base empírica da pesquisa. No processo de análise, sistematização e interpretação dos dados empíricos, o foco foi a especificidade do caso concreto, quanto ao caráter universal da sua manifestação, visando um processo de refinamento de problemas e conceitos.

Para as entrevistas, foi utilizado um roteiro semiestruturado (MINAYO, 2010) dividido em quatro partes: (a) informações pessoais e profissionais; (b) perfil socioeconômico; (c) aspectos relacionados à satisfação no trabalho; (d) aspectos relacionados à saúde e vida social. Por razões estratégicas, aspectos ligados ao uso e abuso de drogas lícitas ou ilícitas não foram analisadas, pois tal problemática demandaria novas modalidades de abordagens dos sujeitos não exploradas nesta fase do estudo. As entrevistas foram gravadas em aparelho e transcritas na íntegra após o consentimento do entrevistado.

Para compreender os impactos do confinamento na vida social, as interpretações levaram em consideração os eixos temáticos selecionados 
para a discussão, que, por sua vez, derivaram de recortes das narrativas sobre o confinamento em alto mar, as relações interpessoais e a vida social. Procurou-se em todo o processo de análise do conteúdo coletado em campo integrar texto e contexto, situando a narrativa dos informantes a partir do lugar de onde falavam. Além disso, foi adotada uma perspectiva intertextual que permitiu confrontar concepções e interesses dos diferentes atores abordados, delineando pontos de convergências ou de conflitos entre eles. (MINAYO, 2008, 2010)

Participaram das entrevistas dezoito tripulantes de três navios, contemplando todos os tipos de navios do Comando do Segundo Distrito Naval. Foram incluídos na pesquisa os militares envolvidos com atividades operativas e manobras de navegação e que representavam os diferentes níveis hierárquicos.

A pesquisa teve início após a autorização do Comando do Segundo Distrito Naval e a aprovação do Comitê de Ética em Pesquisa da Faculdade de Medicina da Bahia ( $\mathrm{n}$ - 840.619). Foi garantido o sigilo absoluto aos entrevistados, identificando-os através de números. As diretrizes e normas regulamentadoras de pesquisa envolvendo seres humanos do Conselho Nacional de Saúde (CNS) na sua Resolução 466/12 foram respeitadas, e, todos os entrevistados concordaram com a entrevista, assinando o termo de consentimento livre e esclarecido.

\section{Resultados e discussão}

A análise qualitativa do estudo foi composta por nove sargentos, três cabos e três oficiais. Quanto à especialidade, dos três oficiais, temos dois especializados em máquinas e um armamentista. Em relação aos praças, temos dois armamentistas, dois escreventes, dois especializados em manobras e reparos, dois em motores, um em eletrônica, um operador de radar, um enfermeiro e um arrumador.

Em relação ao nível de instrução dos militares participantes da pesquisa: 12 militares da amostra qualitativa concluíram o ensino médio e apenas três militares apresentaram o ensino superior completo. Dos que concluíram o ensino superior, todos são oficiais que se formaram na própria Força. No que tange a idade, os militares entrevistados apresentaram de 24 a 46 anos. Em relação ao tempo de carreira possuem de 6 a 29 anos e quanto ao tempo de embarque possuem de 2 a 23 anos. 
Paradoxalmente, esses militares que servem embarcados nos meios operativos $^{1}$ são os que têm maior dificuldade no acesso aos programas nas áreas de qualidade de vida e saúde da marinha, seja por estarem com frequência em comissões quando estes projetos se realizam ou quando em terra, pela intensa rotina de preparação do navio para habilitá-lo à comissão seguinte.

As categorias analíticas centrais identificadas neste estudo se constituíram na modalidade de trabalho confinado na marinha e na perda da identidade social do marinheiro com a sua aposentadoria. Estas foram identificadas como condições essenciais para reflexão na qualidade de vida durante a vida laboral e, por decorrência, na preocupação com a vida enquanto aposentado.

O confinamento em alto mar e o "destreinamento" da vida familiar: instituição total não totalitária

Quando pedimos para os militares descreverem o que pensam sobre o confinamento a maioria apresentou um sentimento de perda de tempo e de vida e caracterizou como "ruim", "complicado", mesmo que "adaptável”: "Eu estou há 23 anos confinado praticamente... Eu já acostumei... É uma vida... É muito difícil, penso que perdi muito tempo...”. (Militar 3, Navio 2) Outro fato observado é a perda da noção do tempo quando embarcados:

Se eu the disser que já passei dois, três dias sem saber o que é a luz do sol, talvez você não acredite, mas é possível, você passar dias sem saber o que é a luz do sol. Você fica dentro do navio e o navio tem tudo, você não precisa sair pra nada. Em navios grandes acontece de vocêficar dias sem ver a luz do sol. Você tem sua rotina, seu serviço, volta pro seu alojamento e fica sem ver a luz do sol... (Militar 1, Navio 2)

Outra afirmação muito citada é o fato de o tempo demorar a passar ou o dia parecer mais longo como comenta um militar: "Cada dia parece uma semana... A questão da ausência da família é ruim”. (Militar 2, Navio 3)

Além da noção do tempo ser distinta a dos trabalhadores comuns, sentem uma grande necessidade de serem mais presentes na vida da família quando estão em terra. Possuem o desejo de realizar várias atividades e compensar o tempo perdido, como podemos compreender nas falas a seguir:

1 Entende-se como meios operativos, os navios, submarinos e aeronaves que executam as operações navais de guerra da Marinha do Brasil. 
O confinamento é bom e ruim. Quando está confinado você dá mais valor ao que está lá fora e quando você está lá fora, você dá valor ao que está aqui dentro. Às vezes no mar, eu fico ali na polpa do navio do nada, olhando pro mar é é bom pra refletir e não tem ninguém ali do lado. E quando chego de viagem, pego minha esposa, a gente sai pra jantar, a gente vai passear e não vira rotina. Acaba sendo uma coisa legal sabe... (Militar 2, Navio 1)

Quando estou em casa eu procuro dar atenção, sair, conversar pra compensar... Em viagem a gente não pode ligar, tem comissão operativa que não pode ligar e também tem dias que não tem sinal o telefone. No dia do meu aniversário minha avó morreu e eu estava no mar também... Foi bom até eu não saber, pois é complicado... No mar a gente não tem o que fazer... Às vezes é bom a gente nem saber. (Militar 2, Navio 2)

O confinamento rompe periodicamente laços sociais de afeto que podem repercutir na dinâmica psíquica no cotidiano do trabalho. Uma das principais dificuldades enfrentadas durante as comissões que apareceram nos discursos dos militares é a ausência da família. Muitos servidores da marinha narraram com tristeza à perda de eventos familiares e sociais importantes:

A minha ultima filha eu não vi nascer. Uma fez 18 anos eu estava viajando, a mais velha fez 15 anos e eu não estava em casa, a outra fez 15 anos dois anos atrás e eu não estava em casa. Hoje elas entendem, mas quando eram crianças não entendiam. (Militar 2, Navio 2)

Meus filhos são pequenos ainda. Eles não têm muito entendimento acerca do meu trabalho. A minha esposa o que ela mais reclama é da inconstância de rotina e das viagens, que apesar de dar o suporte financeiro, têm o afastamento de casa, que sempre causa transtorno. (Militar 1, Navio 1)

Os militares entrevistados afirmaram que o relacionamento no navio “é muito bom”, porém alguns apontaram que durante o período de confinamento pode haver mudança no comportamento dos militares devido o aumento do ritmo de trabalho. Como podemos verificar na narração a seguir:

Dentro do navio nós temos uma família. No mar o humor cai um pouco... Às vezes uma brincadeira que vocêfaz no porto, no mar você não pode... Até porque no mar tem mais exigência. A escala é mais apertada... todo mundo a bordo suja-se mais e tem que limpar mais...e não pode jogar no mar, daí acumula...são muitas exigências. (Militar 5, Navio 2) 
Para Salles e Costa (2013) o trabalho em um ambiente confinado é compreendido pelos sujeitos como fonte de superação de desafios diários, tanto no que se refere à própria atividade quanto à rotina de isolamento pela qual eles passam. Dessa forma, percebemos que o trabalho confinado pode influenciar no comportamento e relacionamento da tripulação. Essa convivência, no ambiente confinado, sob o ponto de vista da peculiaridade e da temporalidade remete ao conceito de instituição total adotado por Goffman (1987, p. 11-16), a saber:

Uma instituição total pode ser definida como um local de residência e trabalho onde um grande número de indivíduos com situação semelhante, separados da sociedade mais ampla por considerável período de tempo, levam uma vida fechada e formalmente administrada. [...] Seu fechamento ou seu caráter total é simbolizado pela barreira à relação social com o mundo externo e por proibições à saída que muitas vezes estão incluídas no esquema físico - por exemplo, portas fechadas, paredes altas, arame farpado, fossos, água, florestas ou pântanos.

Goffman (1987), em seu estudo, relacionou as instituições totais em grupos distintos, tais como instituições que cuidam de pessoas incapazes, penitenciárias ou campos de concentração, pessoas que realizam alguma tarefa de trabalho em locais como quartéis, navios, escolas internas e, por último, locais de formação para religiosos. A partir dessa caracterização observa-se que o trabalho dos militares embarcados pode se inserir na noção de instituição total, já que o trabalho é desenvolvido em um todo ambiental, psíquico, social e cultural dentro de um navio, sem acesso ao mundo externo após o período trabalhado.

Esse sistema fechado detém o controle total da vida de seus membros durante o período de permanência nos mesmos, ou seja, nesses ambientes todos os aspectos da vida são desenvolvidos em um único local e submetidos a uma única autoridade. Não obstante, cada momento da vida diária é realizado em companhia de um grupo de pessoas e todas as atividades cotidianas obedecem a horários pré-determinados e a um sistema de regras. (LEITE, 2009) No caso da Marinha do Brasil, o controle total é exercido pela rotina laboral do navio, onde os toques dos apitos no fonoclama ${ }^{2}$ sinalizam a hora

2 Fonoclama é um equipamento de amplificação e distribuição do som utilizado na Marinha do Brasil, destinado a transmitir ordens verbais a bordo ou em terra. É também conhecido como "boca de ferro". 
de acordar (alvorada), os horários das refeições, as rendições de serviço, os exercícios reais e simulados no mar e os avisos de "reunir” para a tripulação receber as ordens do dia pelo comandante do navio. Toda essa rotina é submetida à observância e o acatamento integral das leis, regulamentos, normas e disposições que fundamentam o organismo militar. Esse aspecto é bem conduzido por Leite (2009, p. 104), quando sinaliza:

O obstáculo que as instituições totais colocam entre os homens que habitam os seus espaços e o mundo externo assinala um primeiro corte que diferencia esse espaço institucional dos demais. Na vida civil em geral, tanto as rotinas diárias quanto os ciclos de vida não se tornam impeditivos para que um papel que o trabalhador desempenhe não obstrua sua efetividade e suas ligações em outro. No entanto nas instituições totais, a separação entre os dois mundos perturba a sequência de papéis, pois essa situação pode perdurar por muitos anos. Mesmo quando retorne ao mundo civil e restabeleça alguns destes papéis, muitas dessas perdas, por vezes, são irrecuperáveis.

Deste modo, percebemos que esses trabalhadores vivem em um estado de vigilância constante durante as viagens, pois estão mergulhados no ambiente de trabalho, mesmo no período de descanso. Pode-se dizer que o confinamento em alto mar provoca esse efeito totalizante descrito por Goffman (1987), diante da distância da família, somados à ausência de um convívio social externo e uma rotina rígida formalmente administrada.

Dos 15 militares entrevistados, somente quatro disseram possuir amigos fora do ambiente de marinha, justamente os que têm menos tempo de carreira. Esse fato desvela uma lógica interna do grupo em que a rotina em uma instituição total dificulta a manutenção dos relacionamentos externos a esse meio, como afirma o militar:

Tenho poucos amigos fora do ambiente de marinha... O militar se socializa com quem está ao lado dele. Nenhum professor fica trancado 20 dias dentro de uma escola, o militar da marinha fica no navio... Às vezes precisa dividir uma pasta de dente... Se ele fizer um churrasco ele vai chamar quem? A pessoa que ele conversou 20 minutos na lanchonete ou o amigo da marinha...? Claro que é o amigo da marinha. (Militar 3, Navio 1) 
É possível notar claramente nas falas o afastamento dos amigos de infância e o sofrimento gerado por essas perdas.

Eu só tenho meus amigos aqui no navio. Vida social é uma coisa difícil de lidar. A vinte e poucos anos atrás que eu entrei na marinha eu tinha um monte de amigos. Hoje quando eu vou de férias pra minha cidade natal, Fortaleza, todo mundo que era meus amigos não são mais. O cara nem vai mais lá em casa, a gente fica lá um tempão, o cara não aparece, perde o contato... Quando eu servia aqui como marinheiro eu tinha um monte de amigos paisanos, mas perdi o contato. (Militar 2, Navio 2)

Um fato importante de se destacar é que em distritos navais fora da cidade do Rio de Janeiro, os militares podem de acordo com os critérios de elegibilidade e disponibilidade, residirem em Próprio Nacional Residencial (PNR) nas vilas navais. Sendo assim, o militar sai de sua organização militar no final do horário de expediente e vai para sua casa localizada muitas vezes dentro dos muros da própria base militar. Deste modo, esses trabalhadores não conseguem sair do ambiente de trabalho nem mesmo em seu descanso.

Vida social a gente tem que ter amigos, principalmente de infância, a gente tem que ter proximidade de parentes, a gente não tem... Moro na vila, a maioria dos amigos são colegas de trabalho, a maioria dos amigos da minha esposa, são as esposas dos meus colegas de trabalho, mas é diferente de uma amizade que fazemos num bairro onde nascemos... Hoje a minha vida social é restrita a família. (Militar 5, Navio 2)

A convivência dos marinheiros muitas vezes ultrapassa a fronteira do mar, uma vez que penetra na intimidade da vida privada, no período do descanso em casa. Castro (2007) afirma em seu estudo sobre os militares que a interação social é endógena e estimulada formalmente pela instituição através da organização de eventos de confraternizações e pelos próprios militares ou familiares.

Portanto, aspectos sobre as repercussões na vida social resultantes da organização do trabalho de pessoas isoladas em embarcações foram avaliados nessa investigação. São exemplos: os afastamentos prolongados do convívio com os familiares devido às viagens operativas, às ausências em eventos sociais domésticos simbolicamente importantes, bem como a escassa comunicação com o meio social mais amplo repercutindo na dificuldade em manter amigos de infância ou mesmo na aproximação com pessoas 
que não fazem parte do ambiente de marinha, dentre outros. Trata-se de condições não estranhas aos marinheiros, apresentadas como pressupostos conhecidos e compreendidos por eles, como expressa o Militar 2, Navio 2: “... eu atribuo isso à rotina do trabalho de um navio, pois é uma rotina imprevisível”. Tais características intrínsecas e incontornáveis no cotidiano dos militares embarcados, mesmo aceita por eles, necessitam de estratégias de superação para reduzir repercussões negativas na qualidade de vida.

Os embarcados vivenciam assim uma instituição total, mas diferentemente de um manicômio, estruturado em práticas de exclusão social intencional e governados por métodos perversos impostos aos sujeitos doentes, não há totalitarismo na gestão e na autoridade imposta ao comportamento dos indivíduos. O distanciamento representa condição natural do trabalho no mar e o isolamento é justificável como método de guerra, com função maior de defesa da pátria, no qual os marinheiros aderem, defendem também com valores constitutivos no modo de trabalho. Nesse caso, não há rupturas com o princípio da transparência e com o direito de saber. Com isso, entende-se que a natureza da organização do trabalho verificada neste estudo desvela uma instituição total, porém não totalitária. Tal condição, embora ainda provoque repercussões na qualidade de vida desses militares, atenua o processo de trabalho isolado dos embarcados.

Logo, nota-se que a forma de se viver na marinha e fora dela marca a diferença entre esses militares e os demais trabalhadores que não exercem sua atividade laborativa no regime de confinamento, dentro de uma instituição total, porém não totalitária. Essa peculiaridade colabora para a construção de uma identidade social própria e uma ambivalência dos papéis desempenhados em cada momento da vida.

\section{A perda da identidade social com a aposentadoria: "destreinamento" da vida em sociedade}

O efeito "destreinamento" da vida em sociedade resultante de uma vida em instituição totalizante foi descrito por Goffman (1987). Trata-se do fenômeno dos “institucionalizados” em que a perda do convívio social exclui possibilidades de retorno à sociedade após afastamento da instituição. $\mathrm{Na}$ marinha, esse fenômeno tem levado a preocupação dos Núcleos de Assistência Integrada com a passagem dos militares para a reserva remunera- 
da. As diretrizes da Política de Assistência Social das Forças Armadas e os programas e normas contidos na publicação da Diretoria-Geral do Pessoal da Marinha - DGPM-501 ( 5 a Revisão) ${ }^{3}$ orientam para a implementação de projetos voltados para esse público alvo. Os projetos buscam minimizar os impactos ocasionados pela alteração do estilo de vida por conta da reserva/ aposentadoria, através de atividades de cunho socioeducativo e reflexivo.

Além disso, a Diretoria de Assistência Social da Marinha (DASM) incentiva à promoção de projetos voltados aos militares que já estão na reserva/aposentadoria, com a intenção de fazê-los se sentir vinculados a um grupo. Esses projetos se operacionalizam através de atividades socioeducativas, culturais e encontros anuais em organizações militares da Marinha de todo o Brasil. (BRASIL, 2010)

Percebe-se que as características encontradas em um grupo de militares são diferentes das atribuídas a outros grupos. Na psicologia social esse fenômeno é chamado de "Identidade Social". Em um estudo pioneiro sobre essa temática Tajfel (1982, p. 292) afirma que "a identidade social é parte do autoconceito do indivíduo que se deriva do conhecimento de seu pertencimento a um grupo social, ou grupos, com o significado valorativo e emocional associado a este pertencimento”. Um estudo mais recente de Vala (1997, p. 10) informa que:

A identidade social pode ser concebida como decorrendo da resposta que os indivíduos se dão à interrogação seguinte: "Quem sou eu?’ [...] e é provável que parte da resposta a esta questão venha da associação entre $\mathrm{o}$ eu e diversas categorias sociais [...] Contudo, uma vez associado o eu à pertença a uma categoria ou grupo social, os indivíduos levantam uma nova questão: $\mathrm{O}$ que significa pertencer a este grupo?

Sabemos que nas diversas organizações militares existentes, criam-se vínculos, desenvolvem-se afetos, moldam-se hábitos, costumes peculiares e dialetos próprios, que dificilmente são esquecidos na vida fora da caserna. Ao narrar sobre as relações de amizade, um militar afirma que possui somente um amigo fora do ambiente de marinha, contudo, ao descrever esse relacionamento ele

3 Publicação que rege a intervenção dos profissionais que compõem os Núcleos de Assistência Integrada ao Pessoal da Marinha. Este serviço tem por objetivo atender as demandas dos militares da ativa, servidores civis e seus dependentes nas áreas de Serviço Social, Psicologia e Direito, bem como tem por proposta desenvolver atividades integradas a estas disciplinas. 
conta que esse único amigo fazia parte da instituição, contudo foi reformado ${ }^{4}$ por causa de um problema de saúde. Nessa fala, ele toca em um ponto crucial dos impactos que essa condição pode proporcionar aos militares que deixam a farda por algum motivo, a sensação de perda da identidade. Vejamos:

Eu tenho um amigo no Rio que era da marinha também e teve uns problemas e saiu... Quando a gente servia na fragata, nós trabalhávamos com solvente e não tinha o cuidado de colocar os EPIs e ele ficou com leucemia. E ele ficou avariado, metade do corpo dele ficou paralisado. Amigo mesmo, ele é o único que eu considero. Ele é o único amigo que a gente está sempre se falando. São diversos fatores daquele que trabalha embarcado. Um deles é a perda da identidade. Pois o meio fica diferente quando a gente se afasta... Até hoje esse meu amigo continua conversando sobre os navios... Um dia ele me ligou chorando porque ele ficou sabendo que a Fragata Defensora iria dar baixa... A gente fica deslocadofora desse ambiente. (Militar 2, Navio 2)

Se a aposentadoria pode proporcionar a sensação de perda da identidade social para todos os tipos de trabalhadores, imaginemos os militares que prestam suas atividades laborativas em instituições totais não totalitárias e construíram suas relações sociais dentro dos muros de um quartel ou de um navio.

Na Marinha do Brasil, as manifestações essenciais do valor militar, como a defesa da pátria com o sacrifício da própria vida, estabelece uma idealização do servidor como um herói e essa representação se articula com os objetivos da instituição, como se estabelecesse uma única identidade. $\mathrm{O}$ sentimento de orgulho tem como ideia central uma representação que une esses trabalhadores. Todos estão juntos na mesma faina, no mesmo barco e apesar de todo cansaço, do esforço, do confinamento, das condições e jornada de trabalho conseguem alcançar o objetivo comum.

Estas maneiras de proceder coletivamente em meio às adversidades, podem lhes exigir criatividade, iniciativa e companheirismo e se caracterizar como fontes de prazer. A fala de um militar sobre a vida social restrita à marinha revela a preocupação dele com o período da reserva: ${ }^{5}$

4 A reforma é aplicada com base na condição de saúde do militar-Lei n 6880/80, Art. 104 a 114. Os militares reformados estão dispensados, definitivamente, da prestação de serviço na ativa, mas continuam a perceber remuneração da União.

5 A reserva na marinha é o conjunto dos militares da reserva remunerada e de cidadãos que cumpriram, na marinha, os requisitos legais do serviço militar e os que deles foram dispensados, estando ainda sujeitos a convocações ou mobilizações, de acordo com a Lei nº 6880/80. 
Eu acho que a única característica diferente do militar da marinha é que a vida social se limita às pessoas da marinha, talvez seja mais dificil ir para a reserva, pois você retoma uma vida social mais aberta. Como militar e devido ao confinamento dos navios e as Forças Armadas terem o seu linguajar próprio, o seu cotidiano próprio e a forma de viver próprias, a sua vida social acaba se limitando a $80 \%$ ser dentro do convívio de marinha, porque seus amigos onde estão? Dentro da marinha... As pessoas que você pode conversar estão aonde? Dentro da marinha... E você terá dificuldades com certeza na reserva, pois você acaba se afastando dessas pessoas e precisa adquirir hábitos sociais diferentes com pessoas que jamais vão entender o confinamento dentro de um quarto 3x3. (Militar 3 , Navio 1)

Além da perda da identidade, materializada na Marinha do Brasil pelo status social a que o trabalho militar proporcionava, somado ao distanciamento da rede social do trabalho, a aposentadoria no imaginário social muitas vezes é associada a um emaranhado de preconceitos e estigmas sociais, pois é por meio do trabalho que as pessoas buscam saciar suas necessidades básicas e motivacionais. Como cita Zanelli e Silva (2008 apud ZANELLI; SILVA; SOARES, 2010, p. 22):

Em que pesem as mazelas e metamorfoses processadas na atualidade, o trabalho ocupa um inegável e largo espaço na constituição da existência humana. Insere-se entre as atividades mais importantes, constituindo fonte relevante de significados na constituição da vida humana associada. A ocupação de um ser humano, expressa por meio de suas atividades diárias, ao satisfazerem suas necessidades básicas e motivacionais, compõe elemento central do seu autoconceito, que se torna vital à construção de sua autoestima.

Nota-se que o isolamento em relação à vida civil aumenta à medida de que a prática profissional se torna mais operativa e a perda do vínculo profissional pode influenciar na identidade pessoal, uma vez que a aposentadoria acarreta modificações nas relações instituídas entre indivíduo e a sociedade. Corroborando com este pressuposto, Rodrigues e colaboradores (2005) argumentam que além desses comprometimentos, a aposentadoria pode representar perdas materiais, psicológicas e sociais. Portanto, diante destas configurações, cabe refletir sobre a chegada à aposentadoria para esse grupo de militares que exercem sua atividade em regime de confinamento em navios, pois os mesmos poderão enfrentar diferentes realidades nesta fase da vida. 
A imagem que o militar faz de si, a construção da sua identidade, é perpassada por um processo a que nos referimos simbolicamente de "tirar a farda”. O simbolismo do uniforme que este militar deixará de usar faz com que ele se sinta estranho a esse espaço social, tendo dificuldade de se adaptar à nova rotina e à dinâmica familiar, muitas vezes preterida em função das exigências afetas ao trabalho. Nesse sentido, a aposentadoria pode representar um desafio ainda maior para esta classe de trabalhadores, servidores da pátria e também para a sua família, por ser um momento de profundas mudanças, que requer a construção de novos caminhos pessoais e profissionais.

Um militar quando se referiu à educação dos filhos narrou que sente falta de estar perto "para dar uma instrução necessária, para dar uma correção". (Militar 4, Navio 1) Fazendo uma analogia aos trabalhadores offshore, o estudo de Salles e Costa (2013, p. 238) afirma que: "nos períodos de folga do trabalhador, o tempo de sua família é regido por horários que não são compartilhados com ele. Além disso, quem fica no lar precisa também se ocupar do papel de quem está fora”. Dessa forma, quando há o retorno definitivo ao lar, a troca de papéis não é facilmente restabelecida. Para Aragão e colaboradores (2008), após o término da carreira, as relações se limitam ao ambiente familiar, obrigando o indivíduo a criar novos mecanismos para reinserção familiar que implica em distribuição do espaço doméstico, assim como o estabelecimento de um novo equilíbrio da dinâmica familiar. $\mathrm{O}$ retorno definitivo para casa, que já possui uma dinâmica própria, pode trazer consequências no âmbito das relações intrafamiliares.

A saúde do trabalhador vem discutindo as problemáticas das repercussões negativas na qualidade de vida com a aposentadoria. Estratégias por meio de exames médicos e psicológicos preparatórios para a aposentadoria se somam à proposição da realização de exames médicos e de saúde de natureza pós-ocupacional. Estudos mostram que exames de saúde pós-ocupacional ou pós-aposentadoria têm sido uma preocupação nas reformas dos modelos de exames de saúde, inclusive para o setor privado. (KIM; PARK; MOON, 1999) Uma das características desses exames se refere ao compromisso com a preservação da qualidade de vida após a aposentadoria. Essa perspectiva poderia ser agregada ao universo dos aposentados militares. Esses não serão descartados na aposentadoria como se faz comumente no modelo inscrito para o assalariado do setor privado. Assim, como há o compromisso pecuniário de natureza econômica que mantém a base salarial do 
militar na aposentadoria, adita-se a nova condição de dar suporte à saúde nessa fase da vida, em que se organiza o acompanhamento médico e psicossocial sistematicamente por meio de exame periódico pós-aposentadoria durante o tempo indicado para preservação da saúde física e mental do aposentado, como compromisso da instituição.

Essa pesquisa revelou que o trabalho em navios da Marinha do Brasil ocupa um importante espaço na vida dos militares e de suas famílias e que a identidade desses trabalhadores é construída a partir do pertencimento a esse grupo. Zanelli, Silva e Soares (2010) informam que a pessoa pode se considerar mais ou menos importante dependendo de seu papel profissional e do poder e prestígio de que dele advém e por meio do desempenho desses papéis as pessoas constroem suas identidades.

Desse modo, constatou-se que o momento da aposentadoria tem notável relevância para esses servidores, surgindo temores ligados ao isolamento e inutilidade. Trata-se de um momento subjetivo que envolve crenças e histórias de vidas distintas. Esse estudo reforça a importância dos projetos voltados à preparação para a reserva/aposentadoria, pois esse período de transição requer a criação de um rito de passagem para o militar e sua família, com acompanhamento de profissionais especializados como psicólogos e assistentes sociais, de modo a estimular uma transição saudável, por meio do auxílio na elaboração de projetos de vida, de modo a minimizar ou prevenir o aparecimento de dificuldades psicossociais. Além disso, os projetos associados a vivências grupais e culturais desenvolvidos para o militar que já está na reserva/aposentadoria pode estimular novas possibilidades de integração, criando condições para o participante encontrar alternativas de amizades compatíveis com seus interesses pessoais nessa fase da vida.

\section{Considerações finais}

O trabalhador militar na marinha, dotado de sua história de vida e de sua subjetividade muitas vezes encontra-se prisioneiro de um regime de efeito totalizante, sem mesmo notar. Longe da terra, da família, sua rede social mais ampla, não somente trabalha na Marinha do Brasil, porém a sua identidade se confunde com a da própria instituição. Desse modo, quando atinge o momento de "retirar a farda" e retornar ao mundo civil, encontra muitos desafios pela frente. Desafios esses que são inerentes ao confinamento e ao isolamento 
que vivenciaram durante 30 anos de serviço à nação. Entretanto, este estudo denotou expressões indicando que a magnitude temporal dessas experiências de isolamento não violou valores e princípios como da transparência e do direito de saber sobre o significado do confinamento inerente à organização do trabalho dos militares embarcados da Marinha. A natureza do confinamento dessa instituição é totalizante, porém a governança não é totalitária, o que se expressa na vontade do retorno ao mar dos marinheiros após a aposentadoria.

Esses militares, apesar da dedicação exclusiva ao serviço, ainda têm o trabalho invisível aos não conhecedores dessa realidade. Esse fato causa um espaço ainda maior entre esses dois mundos, dificultando a aproximação e o vínculo de amizades fora do ambiente institucional. Amizades duradouras são construídas em meio a adversidades dentro de um espaço cheio de regras, valores e tradições próprias. O sentido literal da palavra "servir" é contado através dos relatos de vida e das experiências das operações em alto mar.

O tempo dos militares embarcados é determinado pelas escalas de serviço, pelas comissões operativas ou pelo acionamento para os salvamentos de pessoas ou embarcações no mar. Desse modo, muitas vezes não lhe é permitido planejar viagens, participar de comemorações e eventos sociais. O sonho inicial de desbravar o oceano, com o passar dos anos é fragmentado pelo cansaço e o conflito entre o mar e a terra. Projetos são postergados e acontecimentos não são vividos dentro da contradição entre o papel do homem do mar ou do pai, marido, amigo ou filho presente.

Portanto, esse estudo trouxe contribuições no sentido de fundamentar que a hipótese apresentada para a investigação tem consonância com a realidade e que o processo de trabalho em navios operativos da Marinha do Brasil repercute na vida social de seus militares, particularmente na qualidade de vida. A pesquisa apontou ainda que esse fato pode trazer prejuízos, como a perda da identidade social, $\mathrm{o}$ isolamento e o sentimento de inutilidade num período sensível de suas vidas - a aposentadoria -, pela qual retornarão à convivência mais intensa com a família e a sociedade mais ampla. Reconhecer tais repercussões abre possibilidades para construção ou reorientação de estratégias que enfatizem a melhoria da qualidade de vida e a proteção à saúde do militar da Marinha em atividade e/ou aposentado.

Dessa forma, entende-se que a identidade desses trabalhadores militares, mediada pelo cotidiano do confinamento, se expressa contraditoriamente entre dilemas e sofrimentos vivenciados na vida profissional com saudosismo 
preservado afetivamente na memória após a aposentadoria com expressivo desejo de retorno ao mundo do trabalho. É importante compreendermos que esses militares estão inseridos em um contexto que caracteriza o trabalho como uma missão e exalta o ato de trabalhar, conferindo-lhe significância social. Esse fato traz ainda mais valor e carga afetiva para a atividade laboral.

Algumas limitações metodológicas restringiram imersões em reflexões sobre a relação entre qualidade de vida e saúde nesse estudo. Exemplifica-se não a abordagem da problemática do uso e abuso de drogas lícitas e ilícitas na vida dos embarcados. Entretanto, as riquezas empíricas observadas em relação à exploração de outras categorias analíticas permitiram conclusões contributivas com a temática no âmbito da literatura pertinente.

Assim como existem normas regulamentadoras para o trabalho confinado para os empregados pela Consolidação das Leis do Trabalho (CLT), esse estudo sustenta a importância de propostas que especifiquem e legitimem a manutenção/promoção da saúde do militar embarcado nas atividades de confinamento da marinha, considerando as peculiaridades da vida e trabalho dos "homens do mar". Acredita-se que a discussão das questões levantadas, principalmente pelos profissionais que atuam na Marinha do Brasil nos Núcleos de Assistência Integrada, com a participação dos militares e seus familiares, poderá contribuir para o planejamento, execução e aprimoramento de projetos voltados ao pessoal embarcado.

\section{Referências}

ARAGÃO, C. A. S. et al. Reserva com Qualidade. In: ENCONTRO DAS FORÇAS ARMADAS, 2., 2008, Rio de Janeiro. Anais... Rio de Janeiro, 2008.

BRASIL. Decreto $n^{\circ} 5 \cdot 417$, de 13 de abril de 2005. Aprova a Estrutura Regimental e o Quadro Demonstrativo dos Cargos em Comissão e das Funções Gratificadas do Comando da Marinha, do Ministério da Defesa, e dá outras providências. Diário Oficial [da] República Federativa do Brasil, Poder Executivo, Brasília, DF, 14 abr. 2005. Seção 1, p. 1.

BRASIL. Ministério da Marinha. Normas sobre a Assistência Integrada na Marinha do Brasil-DGPM-501. 5. rev. Rio de Janeiro: Diretoria de Assistência Social da Marinha, 2010. Mod. 2.

BRASIL. Ministério da Saúde. Resolução no 466, de 12 de dezembro de 2012. Diário Oficial [da] República Federativa do Brasil, Brasília, DF, 2012. 
BRASIL. Ministério do Trabalho e Emprego. Portaria ${ }^{\circ}$ 202, de 22 de dezembro de 2006. Aprova a Norma Regulamentadora n. 33 (NR-33), que trata de Segurança e Saúde nos Trabalhos em Espaços Confinados. Diário Oficial [da] República Federativa do Brasil, Brasília, DF, 27 dez. 20o6. Disponível em: $<$ http://acesso.mte.gov.br/data/files/FF8o8o812BE914E6012BF $3 \mathrm{EoF}_{1} \mathrm{C}_{52} \mathrm{FBD}$ /p_20061222_202.pdf >.Acesso em:25 mar. 2015.

CASTRO, C. Goffman e os militares: sobre o conceito de instituição total. Militares e Política, Rio de Janeiro, v. 1, 2007.

GOFFMAN, E. Manicômios, prisões e conventos. 2. ed. São Paulo: Perspectiva, 1987. GUIA de guerra naval. 20oo. Disponível em: <http://www.oocities.org/ guerraaeronaval>. Acesso em: 19 mar. 2014.

HALPERN, E. E.; LEITE, L. M. C. A construção do habitus alcoólico e o consumo de bebidas alcoólicas no trabalho entre pacientes militares da Marinha do Brasil. Cadernos Saúde Coletiva, Rio de Janeiro, v. 19, n. 3, p. 356-365, 2011.

HALPERN, E. E.; LEITE, L. M. C. A interseção entre os trabalhos marinheiros e o alcoolismo. Revista Psicologia: Organizações e Trabalho, Florianópolis, v. 13, n. 2, p.111-126, ago. 2013a.

HALPERN, E. E.; LEITE, L. M. C. Etilismo na jornada laboral: peculiaridades da vida naval. Saúde e Sociedade, São Paulo, v. 23, n. 1, p.131-145, jan./mar. 2014.

HALPERN, E. E.; LEITE, L. M. C. Oportunidades de beber a bordo: características do labor naval. Physis: Revista de Saúde Coletiva, Rio de Janeiro,v. 23 , n. 4, p. 1277-1296, out./dez. 2013b.

KIM, Y.; PARK, J.; MOON, Y. Special medical examination program reform proposal in Korea. Industrial Health, Japan, v. 37, n. 1, p. 109-115, 1999.

LEITE, R. M. S. C. Bandeirantes do mar: a identidade dos trabalhadores das plataformas de petróleo. Niterói: Intertexto, 2009.

LIMONGI-FRANÇA, A. C. Qualidade de vida no trabalho - QVT: conceitos e práticas nas empresas da sociedade pós-industrial. 2. ed. São Paulo: Atlas, 2004.

LINS, M. R. F. Viveiros de "homens do mar": escolas de aprendizes-marinheiros e as experiências formativas na marinha militar do Rio de Janeiro (1870-1910). 2012. 383 f. Tese (Doutorado em Políticas Públicas e Formação Humana) - Faculdade de Educação, Universidade do Estado do Rio de Janeiro, Rio de Janeiro, 2012.

MARINHA DO BRASIL. Estrutura organizacional. 2014. Disponível em: <https:// www.marinha.mil.br/content/estrutura-organizacional>. Acesso em: $1^{\circ}$ jan. 2014. MARINHA DO BRASIL. História Naval. 2013. Disponível em: <https://www. marinha.mil.br/content/historia-naval>. Acesso em: 20 dez. 2013. 
MINAYO, M. C. S. O desafio do conhecimento: pesquisa qualitativa em saúde. 12. ed. São Paulo: Hucitec, 2010. (Saúde em debate, 46).

MINAYO, M. C. S. (Org.). Pesquisa social: teoria, método e criatividade. 27. ed. Petrópolis: Vozes, 2008.

MINAYO, M. C. S.; HARTZ, Z. M. A.; BUSS, P. M. Qualidade de vida e saúde: um debate necessário. Ciência \& Saúde Coletiva, Rio de Janeiro, v. 5, n. 1, p. 7-18, 2000.

MINAYO, M. C. S.; SOUZA, E. R. (Org.). Missão investigar: entre o ideal e a realidade de ser policial. Rio de Janeiro: Garamond, 2003 .

RODRIGUES, M. et al. Preparação para a aposentadoria: o papel do psicólogo frente a essa questão. Revista Brasileira de Orientação Profissional, São Paulo, v. 6, n. 1 , p. 53-62, jun. 2005 .

SALLES, D. M. R.; COSTA, I. S. A. Representações do trabalho: estudo sobre confinamento na indústria petrolífera. Revista de Administração de Empresas, vol. 53, n.3, p. 23o-242, maio/jun. 2013. Disponível em: <http://www.scielo.br/pdf/rae/ v53n3/o2.pdf>. Acesso em: 17 mar. 2013 .

SILVA, M.; SANTANA, V. S. Ocupação e mortalidade na marinha do Brasil. Revista de Saúde Pública, São Paulo, v. 38, n. 5, out. 2004. Disponível em: <http://www.scielosp.org/scielo.php?script=sci_arttext\&pid=Soo3489102004000500014\&lng=en\&nrm=iso >. Acesso em: 1 abr. 2014 .

TAJFEL, H. Grupos humanos e categorias sociais: estudos em psicologia social. Lisboa: Livros Horizonte, 1982. Volume 2.

VALA, J. Representações sociais e percepções intergrupais. Análise Social, Lisboa, vol.32, n. 140, p.7-29, 1997. Disponível em: <http://analisesocial.ics.ul.pt/docume ntos/1221840494M6zFQ7xv9Rd55BV5.pdf>. Acesso em: 15 mar. 2105.

ZANELLI, J. C.; SILVA, N.; SOARES, D. H. P. Orientação para aposentadoria nas organizações de trabalho: construção de projetos para o pós-carreira. Porto Alegre: Artmed, 2010. 


\title{
Condições de trabalho e riscos em uma central de
} regulação médica de urgência o caso dos técnicos auxiliares de regulação médica - TARM

\author{
TARCISO DE FIGUEIREDO PALMA \\ PAULO GILVANE LOPES PENA \\ RITA DE CÁSSIA PEREIRA FERNANDES
}

\section{Introdução}

Os call centers podem ser definidos como unidades de produção do serviço de telemarketing. (VENCO, 2006) O telemarketing, como o próprio termo indica, é o marketing realizado à distância por meio do uso de técnicas de telecomunicações, principalmente o telefone, e mais recentemente a telemática, ao associar sistemas informáticos. Nesse sentido, o seu uso intenso requer a formação de centrais telefônicas conceituadas como: “[...] fábricas de comunicação e gestão de informação que nascem dos processos de flexibilização do trabalho e digitalização das tecnologias de informação e comunicação”. (THIRIÓN, 2007, p. 49, tradução nossa) Uma característica que deu forma a essa nova tendência foi a economia de tempo para o cliente e a redução das distâncias. (ASSUNÇÃO; SOUZA, 200o) 
Segundo dados da Associação Brasileira de Telesserviços, no início de 2008, com 750 mil trabalhadores, essas empresas se transformaram no maior empregador na área de serviços. (ABT, 2011) Atualmente se tem um panorama de mais de um milhão de trabalhadores neste ramo produtivo. (ABT, 2011) Há, no entanto, call centers que não são de telemarketing propriamente dito, e que foram incorporados a esse contexto de trabalho. Segundo o Ministério do Trabalho e Emprego, o telemarketing se subdivide em segmentos e, dentre esses, existe aquele que presta assistência técnica e especializada aos usuários do sistema de saúde e aciona serviços emergenciais (BRASIL, 2010), onde se enquadram as centrais de regulação médica do Serviço de Atendimento Móvel de Urgência (SAMU) 192, locus desse estudo.

O interesse no estudo do trabalho em um call center de saúde pública advém de suas características e sua relevância, pois além do teleatendimento ser um dos setores que mais emprega no Brasil, a sua organização do trabalho pressupõe diferentes modalidades de controle dos mecanismos laborais do trabalhador, onde suas diversas consequências, principalmente nos aspectos relacionados à saúde desse trabalhador, alimentam diferentes estigmas à profissão. (RICCI; RACHID, 2013) Soma-se a isso o crescente uso do call center nos serviços públicos em todas as esferas de atenção, proporcionando relação direta entre o modo de organização do trabalho no teleatendimento e a efetividade da atenção prestada, especialmente nos casos de urgência e emergência, cuja repercussão negativa pode ser fatal ou incapacitante para o usuário. São exemplos as aplicações públicas bastante conhecidas, como: Corpo de Bombeiros 193, Polícia Militar 190 e o próprio Samu 192. Muito se discute atualmente sobre as relações da organização do trabalho em call centers e a saúde de seus trabalhadores. Os modos operacionais tayloristas são reorganizados no processo de reestruturação produtiva, com suporte de novas tecnologias, e aprofundam o aperfeiçoamento do controle sobre os movimentos e a produtividade, constituindo-se em modalidades neotayloristas de organização do trabalho. (OLIVEIRA; JACQUES, 2006; VENCO, 2006)

Venco (2006) mostra em seu estudo formas de adoecimento, como Lesões por Esforço Repetitivo (LER), inscritas em ambiente de grande pressão provocado pelo estresse nesses trabalhadores. Esse modelo neotaylorista moderno, oferece à gestão mecanismos mais precisos no pro- 
cesso de supervisão, que perpassam, desde dados estatísticos sobre produtividade de cada teleoperador, à escuta da conversa on time entre este e um cliente, orientados por novas tecnologias de inteligência artificial ou robótica virtual. Conforme demonstra Calderón (2006) e Boutet (2006), o teleoperador precisa seguir rotinas linguísticas pré-concebidas que são repetitivas e que causam descontentamento e estresse. Essa "modernização” das relações de poder, segundo Assunção e seus colaboradores (2006, p. 55) “[...] representa, muitas vezes, uma forma mais facilmente perceptível de pressão pelo seu caráter coercitivo, carregando grande potencial adoecedor”.

Em relação às novas tecnologias que dão suporte às modalidades de controle e intensificação do trabalho, os sistemas computacionais e respectivos softwares se destacam como paradigma essencial na análise do trabalho. Essas novas tecnologias virtuais dão suporte à gestão do processo de trabalho, oferecendo o controle e automação da sua produção, bem como auxilia nas decisões. Tais técnicas de inteligência artificial são definidas como softwares permeados pela linguagem matemática com algoritmo binário, ou um conjunto de instruções, que em execução produzem a função desejada. (REZENDE, 2005)

Segundo Abrahão, Silvino e Sarmet (2005), a emergência de uma abordagem distinta nos processos de informatização do trabalho é salientada por diversos autores que apontam que se deve considerar como fontes de subsídios dos projetos de sistemas informatizados a pesquisa em situação real, verificando a compatibilidade cognitiva entre a representação das estruturas do sistema e as do usuário, obtendo a compreensão das situações em que os sistemas serão aplicados, sua compatibilidade com os processos decisórios envolvidos e as estratégias dos usuários.

Nesse contexto, esse estudo teve como objetivo analisar o trabalho, o uso de softwares de gestão e suas condições de risco à saúde, a partir da ocupação específica de Técnico Auxiliar em Regulação Médica (TARM).

\section{Métodos}

Esse estudo foi realizado em um call center de uma central de regulação médica do Samu 192 na Bahia, utilizando uma abordagem metodológica baseada na pesquisa qualitativa com suporte da Análise Ergonômica do Trabalho(AET). 
Deacordo coma AET, as condições de trabalho resultam da inter-relação complexa dos múltiplos fatores constituintes da situação de trabalho, dos meios disponíveis para a execução das tarefas, dos objetivos postos pela organização do trabalho a serem cumpridos pelo trabalhador e das condições objetivas e subjetivas de cada sujeito que trabalha, em cada momento de seu processo. A escolha desta abordagem visa evidenciar as condições nas quais um importante serviço de utilidade pública é desenvolvido. (GUÉRIN et al., 2001; LIMA, 200o) A investigação teve o apoio de uma central municipal de regulação médica do Samu 192 na Bahia, junto ao corpo de trabalhadores teleoperadores, entre os meses de abril e setembro de 2010. Foi aprovada pelo Comitê de Ética em Pesquisa da Secretaria de Saúde do Estado da Bahia (SESAB).

O quadro de funcionários do Samu 192, desde a central de regulação em todos os turnos aos trabalhadores das unidades móveis (ambulâncias), conta com 103 profissionais por turno de plantão, totalizando 748 trabalhadores. Os sujeitos da pesquisa, os TARMs, representam a maioria dentro da central de regulação, num total de 14 profissionais por turno. (BAHIA, 2010) Doze TARMs participaram voluntariamente da pesquisa, sendo que apenas sete foram entrevistados individualmente. Vale salientar que os nomes dos trabalhadores relacionados nos extratos de narrativas descritos nos resultados são todos fictícios com o objetivo de preservar o sigilo, atendendo aos preceitos éticos da pesquisa com seres humanos.

O presente estudo teve início com uma exploração do funcionamento de um call center do Samu 192. Nesta etapa, procedeu-se a reunião documental e sua leitura, seguida de observações livres. Para a identificação das tarefas e atividade de trabalho foram planejadas e realizadas as observações sistemáticas inscritas em diário de campo. Foram registradas as verbalizações espontâneas dos teleoperadores em situação de trabalho e realizadas entrevistas semiestruturadas, consecutivas ao trabalho, como técnica complementar às observações. O material produzido nessas entrevistas semiestruturadas foi submetido à análise das narrativas propostas por Minayo (2010).

Dessa forma, o estudo baseou-se na abordagem da Análise Ergonômica do Trabalho (AET). Segundo Palácios, Duarte e Câmara (2002, p. 845):

Essa estratégia de investigação possui a vantagem de oferecer maior possibilidade de apreender as situações, identificando seus elementos, colocando-os em relação uns com os outros, 
compreendendo como são construídas as situações e como se desenvolvem em seu movimento próprio.

A situação de trabalho, longe de ter uma característica estável, é marcada pela variabilidade, seja do sistema sociotécnico, seja dos sujeitos que trabalham. Para essa perspectiva da análise situada do trabalho há contextos de trabalho e sujeitos em atividade em relação dinâmica.

A AET compartilha os princípios gerais da abordagem etnográfica como estratégia de estudo, e utiliza como técnica de estudo a observação participante, com a particularidade de incluir a entrevista em autoconfrontação. (DANIELLOU, 2004; GUÉRIN et al., 2001; LIMA, 2000; WISNER, 1994, 1996)

As primeiras observações duraram 19 horas e foram feitas em sete dias diferentes, com 15 horas durante o dia e quatro horas durante a madrugada. Após esse momento, foram realizadas as entrevistas durante turnos de atendimento real. Foram realizadas sete entrevistas, com dois homens e cinco mulheres, num total de 13 horas e 15 minutos. Todos os registros dos ciclos, com número de toques, Tempo Médio de Atendimento (TMA) e frequência de situações foram feitos através de anotações em diário de campo.

Uma vez estruturadas as informações sobre o funcionamento do Samu e sua capacidade instalada, destacou-se inicialmente os fatos relevantes da organização e gestão do trabalho. Registrou-se, em seguida, as principais tarefas, suas exigências, habilidades requeridas, perturbações observadas, comportamentos e verbalizações recorrentes relativas a cada atendimento realizado. Destacou-se também as características comuns aos atendimentos básicos, e as variabilidades decorrentes da regulação das perturbações, que interferiam diretamente no tempo do atendimento. Buscou-se identificar, em situação de trabalho, as ações dos TARMs em face à variabilidade do sistema de trabalho. Ou seja, procurou-se evidenciar o que está além do prescrito nas normas do serviço, conforme indica a AET. (GUÉRIN et al., 2001) A análise considerou o caráter individual e compartilhado do trabalho em equipe no SAMU.

Com o decorrer da pesquisa foram elucidadas questões, e através da imersão no universo empírico resultante das observações e das entrevistas, o trabalho prescrito foi confrontado com o que ocorria, o trabalho real. As reflexões geradas por meio desse confronto se concentraram na identificação de contradições entre a norma e as demandas reais postas aos trabalhadores, permitindo constituir categorias de análises das situações que representassem o real do trabalho dos TARMs. 


\section{Resultados e discussão}

A ação de atendimento do SAMU se inicia por meio de uma chamada telefônica de um usuário dos serviços de saúde. Todos os chamados de urgência feitos para o telefone 192 são direcionados ao call center do SAMU 192, que é uma central de regulação médica. Para atender à demanda da população, essa central deve seguir diretrizes básicas de atendimento, que, segundo o Ministério da Saúde (BRASIL, 2004), são: atender aos chamados telefônicos 24 horas sem interrupção; garantir o acesso do paciente à unidade de saúde - pronto atendimento, pronto socorro, hospital geral ou especializado -, conforme sua necessidade; acompanhar a situação das unidades de urgência; verificar se essas estão com muitos casos para atender; garantir que as equipes médicas estejam completas; conferir se existem leitos vagos; avaliar a situação das UTI's e dos equipamentos para diagnóstico.

O regime de contratação dos funcionários do SAMU estudado é feito por meio do Regime Especial de Direito Administrativo (REDA), definido a partir de Termo de Ajuste de Conduta (TAC) determinado pelo Ministério Público do Trabalho. As categorias ocupacionais de atendimento são o TARM: profissional de nível básico que atende por meio de telefone à demanda da população, preenchendo informações básicas sobre a ocorrência e prestando informações gerais. Sua atuação é supervisionada diretamente e permanentemente pelo médico regulador. Outras categorias ocupacionais são: rádio operador $(\mathrm{RO})$, médico regulador e monitor.

Quanto à jornada de trabalho, o TARM e RO têm escalas de seis horas diárias, com descanso de 20 minutos, enquanto que os médicos reguladores cumprem plantões de 12 horas com descanso de uma hora, folgando por três dias (24 horas semanais). Todos têm possibilidade de dobrar a escala.

\section{Sobre o técnico auxiliar em regulação médica e suas tarefas}

Embora alguns TARM tenham cinco anos na função, o perfil desses profissionais não difere do encontrado nos demais call centers. (ABT, 2011) Em sua maioria são jovens, entre 18 e 35 anos, com predominância de mulheres. Além da inserção no SAMU, em turnos de trabalho de seis horas, muitos deles têm outro emprego ou estudam. A função de TARM se realiza 
como uma porta de entrada do usuário ao sistema de saúde, a um serviço de urgência médica.

A urgência se dá em forma de chamado telefônico atendido primeiramente pelo TARM. Este classifica o tipo de ligação: orientação, engano, trote e urgência com ou sem disparo automático da ambulância. Em seguida ele dá continuidade ao atendimento de forma a conduzir o mais rápido possível seu desfecho.

O TMA varia dependendo das demandas ao TARM, isso porque ele pode, ao mesmo tempo em que preenche um formulário eletrônico, questionar o solicitante, variando então em função do tipo de chamada. Quando o chamado transcorre sem maiores intercorrências, e se trata de caso de urgência, esse dura em média de um minuto e trinta segundos a três minutos.

Em alguns casos especiais, a abertura de uma ocorrência pode durar até mais de seis minutos. Esse ciclo mais longo é gerado a partir da gravidade da ocorrência e da dificuldade de comunicação do solicitante, submetido, na maioria das vezes, aos estressores presentes em uma situação que envolve a urgência médica ou risco de vida para outrem. Conseguir a coleta das informações necessárias para otimizar o tempo de atendimento e manter o solicitante capaz de seguir com as futuras orientações do médico regulador é tarefa posta ao TARM.

Após classificar o tipo do chamado e preencher o sistema com informações iniciais, o TARM repassa a ligação ao médico regulador que faz o atendimento preliminar e também preenche o sistema com informações pertinentes. Em seguida, o médico regulador, munido de um pré-diagnóstico, entra em contato com a rádio operação, que encaminha ou não uma unidade de saúde - a ambulância - para o local da ocorrência.

As tarefas e operações nas quais o TARM está envolvido são expressas da seguinte forma: o solicitante do serviço entra em contato com o SAMU 192 em forma de chamado telefônico, que é atendido pelo TARM, seu primeiro interlocutor. Este segue um ciclo de atendimento, com um TMA, dependente da modalidade da chamada. O TARM pode encerrar a ligação se constatar trote, contato não pertinente ao SAMU, ou engano. Caso o chamado seja pertinente, o TARM então dá continuidade ao atendimento, conforme organograma funcional na Figura 1. 


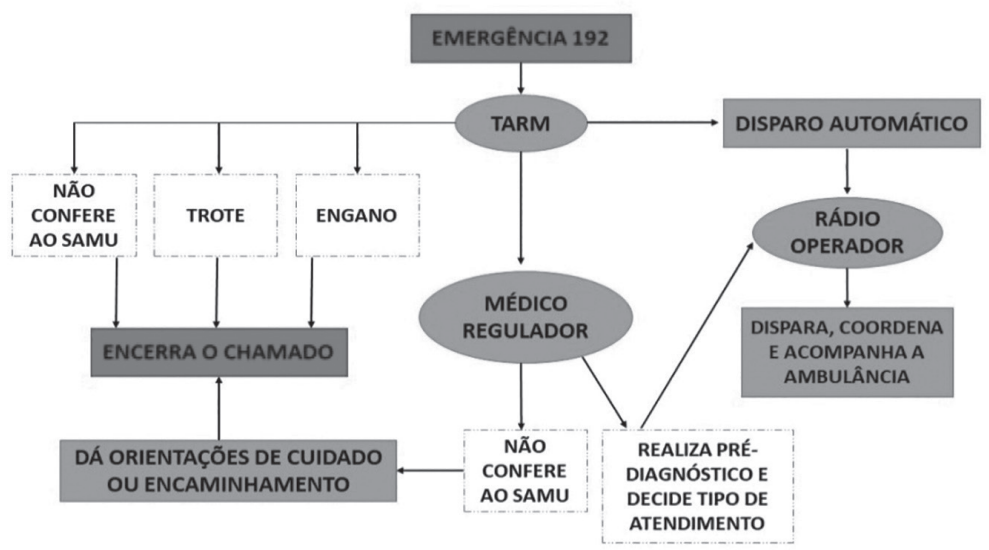

Fonte: elaborada pelos autores.

A partir daí surgem diversas situações. Serão descritas, a seguir, situações que contemplam quase a totalidade dos tipos de chamadas “entrantes”, como trotes, chamadas por engano, para pedido de orientação e as chamadas de urgência. Essas situações estruturais das tarefas do TARM representam as categorias consideradas para a análise do trabalho.

\section{O teletrote $\mathbf{e} 0$ atendimento de urgência}

Nos períodos de elevado fluxo de entrada de chamadas, como final da manhã e final da tarde, essas totalizaram aproximadamente 70 chamadas, entre enganos, trotes, interrupções de ordem técnica e chamadas reais, das quais foram registrados entre 35 e 45 ciclos de trote, no intervalo de uma hora. "Foram 2486! É demais! A tarde toda ligando, você desliga e ele liga de novo... isso irrita demais, e fora que congestiona a linha, tem gente precisando de atendimento e não consegue contato...”. (Armando)

Na figura 2 encontra-se descrito o fluxo do atendimento do TARM centrado no caso do trote, desde o recebimento da chamada, seus desdobramentos, até ao posicionamento final com a definição da existência ou não de trote. O ciclo para um atendimento de chamada considerada que trote, basicamente, dura entre 12 e 23 segundos. Não se pretende contemplar a variabilidade dessa situação neste fluxograma, porém ele exemplifica o processo básico. 
Figura 2 - Fluxograma de procedimentos implementados pelo técnico auxiliar de regulação médica para identificação do trote

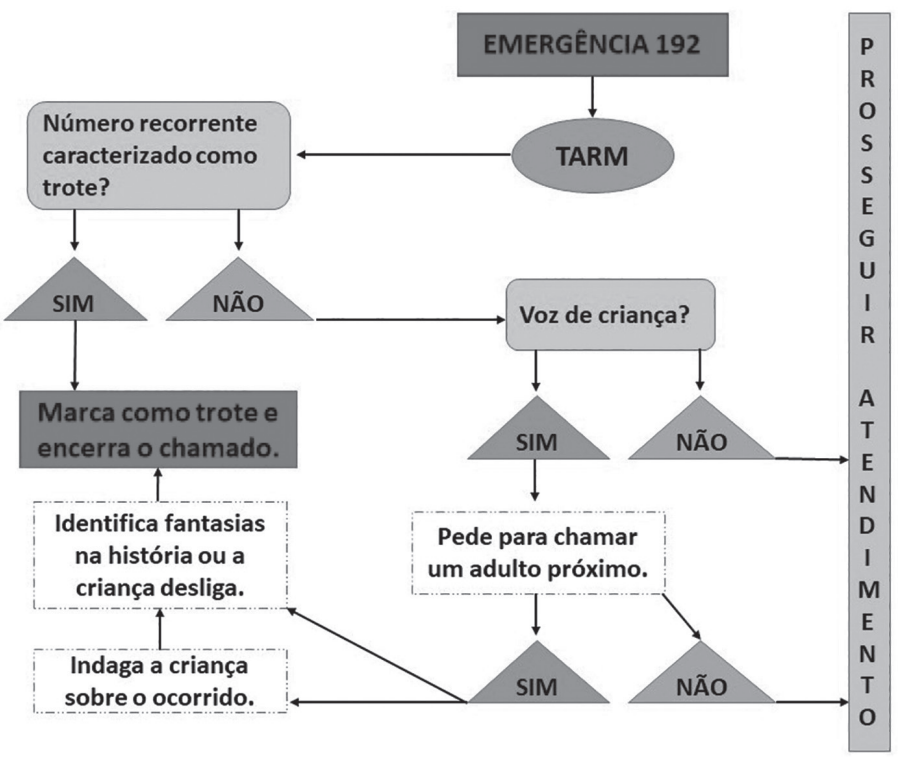

Fonte: elaborada pelos autores.

Na medida em que o fluxo desses trotes aumenta, a tarefa se torna repetitiva, com ciclos curtos, conforme números apresentados anteriormente. A automação pelo software ainda não permite a quebra dessa repetitividade, através da qual, ligações com números recorrentes classificados como trote seriam automaticamente informadas com alertas.

Segundo a percepção dos TARM, os trotes chegam à elevada proporção de $60 \%$. No histórico das ligações, verificou-se que um mesmo número telefônico originou mais de 3 mil ligações caracterizadas como trote.

No Brasil, os serviços públicos de urgência, como Polícia Militar (190), Corpo de Bombeiros (193), além do SAMU (192), como descrito, são acometidos diariamente por essa prática, em que o fluxo de tais ligações alcança aproximadamente $40 \%$ da demanda em algumas regiões. (ANDRADE et al., 2010) Nos estudos de Castro e colaboradores (2006) foi encontrada a alarmante proporção de $42 \%$ de trotes nestes serviços. No Rio de Janeiro, o trote para serviços de urgência é considerado crime, resultando em ressarcimento dos custos do serviço do autor, bem como detenção e multa. (RIO DE JANEIRO, 2012) 
Apesar de representar uma grande exigência de trabalho, verifica-se o paradoxo de não existir protocolo pré-estabelecido de identificação do trote. O software do SAMU, - programa de computador que gere os atendimentos - apesar de contemplar a opção TROTE, oferece apenas o reconhecimento do número de telefone como sendo recorrente e classificado anteriormente como trote, mas não oferece apoio à tomada de decisão. $\mathrm{O}$ cancelamento da chamada é de responsabilidade do TARM e isto gera tensão, devido às consequências de um possível engano, conforme expresso na fala: "Na maioria das vezes a gente acerta. Mas pode ser que dê errado! Aí...”. (Flor)

Para constatar um trote, o TARM utiliza sua experiência no processo de identificação. De uma forma geral, quando o chamado é de criança, em sua grande maioria, caracteriza-se como trote. A experiência é fator importante, principalmente quando o trabalhador recorre à memória de situações análogas para a compreensão de certas situações. (GUÉRIN et al., 2001) Segundo Abrahão e Torres (2004, p. 69), a representação quando associada à ação se refere "[...] às redes de propriedades, de conceitos, de saberes, de habilidades, de crenças e de experiências construídas no decorrer da história do indivíduo, a partir da sua relação com o trabalho”, e que são convocadas em situações nas quais a memória é requerida para viabilizar a ação. $\mathrm{O}$ recurso às experiências vividas previamente é o principal mecanismo utilizado pelo TARM para identificar o trote, conforme verbalizações dispostas a seguir. Caso haja erro, esse profissional assume a responsabilidade das consequências.

Na relação entre usuário e operador de call center, Svensson (2012) revela influências psicoafetivas nos processos de tomada de decisão, porém estabelece uma simbiose em dois sistemas distintos para processamento da informação. O primeiro sistema, qualificado como racional, tem características cognitivas, geralmente mais lento no processo tempo-resposta, demanda algum esforço, é norteado por regras pré-definidas, porém com alguma flexibilidade e neutralidade. Enquanto que o segundo sistema é majoritariamente comandado por afeto, de natureza pré-consciente, rápido, automático, não verbal, e também associado a processos intuitivos. Esses dois sistemas trabalham de forma independente, mas podem também dialogar entre si, ou seja, apresentam características interativas e uso de condutas centradas na linguagem. 
Diante de possível trote, o TARM se depara com situações que são identificadas nessa transversalidade revelada nesses dois sistemas para processamento da informação. No exemplo de chamadas feitas por crianças, a experiência do profissional, mesmo sem suporte do software ou de protocolos específicos, indica o trote. Entretanto, em situações de chamadas verdadeiras, contrariando o padrão, a caracterização errada como trote causa comoção no trabalhador, além da repercussão no quadro do paciente.

Você vê logo, quando é voz de criança: '- moço, moço, está pegando fogo aqui...'; você vê que éuma brincadeira. (Chaves)

Tem chamado que a gente não percebe logo de cara. Aí com o tempo, perguntando uma coisa num momento, repetindo a pergunta em outro, a pessoa se contradiz. Tem gente que não aguenta, pede para sair. Isso cansa mesmo! É pressão! (Armando)

Tal situação gera conflitos, pois para o usuário existe a possibilidade de lidar com a desconfiança do seu atendente (TARM) e isso pode resultar em outra fonte de estresse. Enquanto que para o TARM, apesar de todas as indicações para $o$ ato de trote, existe a possibilidade de ser realmente uma urgência, conflito que o acompanha do início ao final de seu turno. O TARM tem o poder de decidir e isso significa assumir o risco. Conviver com essa contradição causa tensão. Trazendo o que discutem Abrahão e Torres (2004), a propósito das exigências do atendimento em outro call center, o trote, comum nesta central, aumenta a carga de trabalho, pois exige dos TARM maior habilidade na comunicação, manutenção da paciência e da cordialidade em situações que podem ser críticas, adotando estratégias para evitar o fracasso resultante de uma decisão errada.

Para Pascale Molinier (2004), a psicodinâmica do trabalho considera que quando a organização das atividades impossibilita a transformação do sofrimento em prazer, realizações e suporte pessoal, então tal trabalho se torna prejudicial à saúde mental. Situações como essa foram observadas e verbalizadas pelos TARM diante de conflitos entre a tentativa de transformação do trabalho em realizações como estratégia de defesa e equilíbrio, salvando vidas e melhorando o cuidado com o paciente, e a anulação dessa possibilidade condicionada pelas pressões organizacionais limitantes, que geram riscos operacionais capazes de resultar em vivências psíquicas dramáticas, com estresse excessivo associado à conduta equivocada. 
O trote, junto às ligações por engano e orientação somam aproximadamente $70 \%$ da demanda de trabalho do TARM. Todo o complexo de decisões nesse leque se concentra na experiência do TARM, profissão essa sem plano de carreira pública adicionada a alto turnover. Essa condição é pouco considerada nas soluções técnicas e sociais para melhoria simultânea das condições de trabalho e da efetividade do atendimento do SAMU.

\section{O desconhecimento público para o uso do atendimento de urgência}

Além dos trotes, os enganos, pedidos de orientações e chamadas de urgência completam em quase sua totalidade as ocorrências para o SAMU 192. Os enganos podem chegar a aproximadamente $10 \%$, ou mais, das chamadas por hora, e exigem do TARM elaborar uma resposta que auxilie o solicitante, ainda que esta não seja uma tarefa prevista, para a qual o TARM não dispõe de qualquer dispositivo no sistema operacional. Esta situação pode ser evidenciada por meio da seguinte fala: “Ó senhora, já que ele não tá sentindo nada, isso não é para o SAMU, a senhora liga 156, que é do serviço 'X', que é para a população de rua....'. (Flor)

Ao lado das chamadas classificadas como trote, os enganos representam um fluxo expressivo do total geral de ligações e condiciona o congestionamento das linhas telefônicas. Para tratamento dessa demanda incorreta, como no caso citado acima, o software não oferece links com chamadas automáticas para outros call centers, como o do "X", Polícia Militar, Corpo de Bombeiros, entre outros. O tempo despendido nesse processo de atendimento e elaboração de uma resposta favorece o congestionamento das linhas telefônicas e, sobretudo, a sobrecarga psíquica ao exigir o recurso à memória dos operadores.

Em uma perspectiva ampliada, constata-se que não há campanhas educativas para a população em geral, com o objetivo de elucidar questões, como o propósito do SAMU 192 e a importância de solicitar o serviço corretamente. Nesse sentido, Paiva e Avelar (2011) reiteram essa necessidade de melhoria no que tange à ampliação do conhecimento da população a respeito dos serviços de saúde, em especial das funções fundamentais do SAMU 192 no âmbito do Sistema Único de Saúde (SUS). 


\section{A chamada de urgência: insuficiência dos meios e saber-fazer}

Quando a chamada é uma urgência, o TARM pode ter duas ações principais: anotar todos os dados preliminares e passar para o médico regulador para que esse faça o encaminhamento da unidade de atendimento para a ocorrência, via rádio operador, caso julgue necessário; ou, dependendo da gravidade, o próprio TARM faz o "disparo” automático da unidade de atendimento sem passar pelo médico regulador. O TARM segue um protocolo, instituído pelos médicos como eventos de maior urgência, que o autoriza a "disparar" uma ambulância antes de passar o chamado ao médico. Entretanto, não foi evidenciado no sistema utilizado pelos TARM estruturas que gerissem tal situação.

O ciclo de um atendimento de urgência com ou sem disparo automático é o mesmo em termos de dados digitados e duração do contato do usuário com o TARM - média de dois minutos. Na situação de disparo automático, em vez do TARM passar a chamada ao médico regulador e este coordenar o rádio operador para enviar uma unidade de atendimento, a requisição da ambulância é realizada pelo próprio TARM logo nos primeiros segundos do contato.

No cadastro das ocorrências, o TARM precisa navegar por algumas telas e identificar, em meio a muitos campos, o correto local para digitar as informações do paciente. Nesta tela se exige maior tempo de navegação e susceptibilidade a erros sistêmicos, relatados como comuns: "Esse negócio de estar entrando em janela e caindo [...], acho que o sistema deveria ter uma tela só". (Chaves)

O sistema informatizado, ferramenta utilizada pelos TARM, foi concebido sem a participação do trabalhador. Desta forma, constatou-se que não se contempla características de segurança e funcionalidade requeridos na execução das etapas de trabalho dos TARM. Assim, é evidenciada a incompatibilidade entre a ferramenta disponível - software - e as exigências das tarefas. Nos dizeres dos TARM: “Tem dia que enche. [...] Entra barra de rolagem. [...] que cansa...”. (Chaves) “Atender toda hora apertando o botão...” (Evaneide)

É notória a exclusão do trabalhador no processo de construção de sua ferramenta, confirmada nas incoerências sistêmicas presentes nas interfaces do software. A exemplo, o caso da densidade informacional ou na ausência de recursos que apoiassem o trabalhador a tomar decisões diante de situações como a do disparo automático. 
No disparo automático, o erro acontece com frequência, pois os TARM, muitas vezes, enviam desnecessariamente mais de uma unidade móvel para a mesma ocorrência, haja vista os casos de disparo automático requererem pressa devido sua maior urgência. A escolha é do TARM de "errar por excesso", uma vez que a incerteza habita sua decisão e o compromisso de cuidar da vida assume prioridade.

Teve uma colisão, vítima nas ferragens e tal... Não é nem uma nem duas pessoas que vão ligar, são várias, existem muitas portas de entrada. A gente manda muito duas unidades pra uma ocorrência só. [...] Eu mando as duas, eu vou errar pra menos? Eu vou errar pra mais, né? É uma coisa que fica a critério da gente, se for errar pra menos meu irmão... (pausa) Se for uma pessoa que esteja ali numa necessidade, você pode comprometer a vida de uma pessoa. (Chaves)

Não existe na interface do sistema uma estrutura que contemple tal situação, sobrecarregando o trabalhador, que, por conseguinte, quando erra sobrecarrega o sistema de saúde como um todo.

Porém a principal sobrecarga do TARM, conforme a análise permitiu evidenciar, é de ordem psicoafetiva, segundo relatos e situações já mostrados envolvendo o contexto relacional no cuidado com a saúde, e nas ações que envolvem salvar uma vida. Além disso, há exigência de ordem cognitiva, pelo recurso rápido à memória e uso do software.

O próprio software, que em determinados momentos evidencia a sua insuficiência, pode também ser utilizado numa perspectiva de proteção ao seu operador. Segundo Abrahão, Silvino e Sarmet (2005, p. 163) "a dialética entre usabilidade e navegabilidade permite a (re)concepção por meio da lógica de quem usa, ao invés da lógica de quem concebe”, ou seja, o trabalhador deveria ter papel central no processo de reengenharia de sua ferramenta de trabalho. Essa estratégia metodológica está na essência no uso do método ergonômico de análise do trabalho, contudo, geralmente não tem sido objeto de consideração. Sobre isso, Kafure (2010) demonstra a eficácia do uso da ergonomia em concepção com o usuário, participando desde as etapas iniciais do processo. A autora afirma que o sistema, o software, é conhecido muitas vezes pelo operador quando já está em funcionamento, e isso pode ocasionar dificuldades diversas que são derivadas da discrepância, entre as expectativas e necessidades do operador, definidas pelo trabalho real e as tarefas pré-dispostas nas interfaces. 
Evidencia-se na observação e verbalizações, a insuficiência do software quanto aos seus recursos, gerando sobrecarga psíquica e agravando ainda mais as condições estressantes de trabalho.

\section{Salvar vidas: entre o sofrimento e a satisfação}

Constatou-se a satisfação dos TARM em estar desempenhando um trabalho nobre, o de ajudar a salvar vidas. Este aspecto pode representar um efeito de proteção da saúde mental do trabalhador. A satisfação encontra-se no plano individual e na esfera da intersubjetividade que leva a reforçar as ações, mesmo diante de dificuldades no cotidiano. Essa satisfação "refere-se à integração, à autonomia, à motivação, ao envolvimento e à utilização das capacidades físicas e mentais”. (MARQUEZE; MORENO, 2005) "Eu acho que estar lidando diretamente com o salvamento é uma coisa que estimula muito”. (Dr ${ }^{\mathrm{a}}$. Vanessa)

A capacidade de enfrentamento das situações nocivas, dentre elas a submissão a sistemas de inteligência artificial, pode ser percebida pelo trabalhador como fonte de sofrimento, no entanto, a subversão das normas, o uso de sua expertise diante da variabilidade do trabalho, também podem representar a sublimação desse sofrimento, trazendo algum prazer, como uma gratificação psíquica ao trabalhador. (OLIVEIRA; REZENDE; BRITO, 2006; TORRES; ABRAHÃO, 2006)

[...] Tirando o estresse, quando você vê o resultado do trabalho... É gratificante saber que o seu trabalho ajuda as pessoas. (Dudu)

Tem esse lado que é importante também. A responsabilidade de estar lidando com isso. É interessante. É bem importante mesmo. Eu não tinha essa visão antes e agora... Só passa a admirar depois que conhece o trabalho, ofuncionamento, é bem gratificante, às vezes, ver a ocorrência que você abriu e que no final deu tudo certo, que a pessoa está bem. (Evaneide)

Notou-se que o reconhecimento da importância das ações desses trabalhadores por parte dos seus superiores, como também da população em geral, pôde ter resultados positivos. Porém, mais importante do que o reconhecimento alheio é a percepção de que os trabalhadores apresentam sua importância e seu valor para esse trabalho. Isso certamente reforça um sentido de dignidade e felicidade ao desempenhar suas atividades, o que pode 
significar uma defesa para sua saúde psíquica e um estímulo que proporcionam satisfação no trabalho, sendo, segundo Marqueze e Moreno (2005), influência inegável no processo saúde-doença.

Apesar do esforço empreendido em um atendimento, no qual vidas serão ou foram salvas, constatou-se a indisponibilidade de informação sobre o percurso terapêutico seguido pela vítima após o atendimento do TARM que abriu o chamado. Isso consolida a fragmentação do cuidado e do caráter pontual do vínculo estabelecido pelo TARM com o solicitante. É possível que a incorporação de resultados sobre este percurso seguinte do paciente, no próprio software, pudesse significar uma compensação e reconhecimento do trabalho do TARM. Exaltar-se-iam os aspectos positivos do trabalho, fortalecendo a autoestima do trabalhador que lida diariamente com a importante missão de salvar vidas em uma sociedade com elevados índices de violência.

\section{Batismo ocupacional: estratégia coletiva de defesa?}

Outra característica do trabalho do TARM se relaciona com a sua apresentação ao solicitante. Ele, como todos os profissionais em teleatendimento, segue um padrão de recepção com frases prontas, seguindo um script. (ASSUNÇÃO; SOUZA, 20oo) No caso do SAMU, o TARM se apresenta falando o nome do serviço, seguido do seu nome, cumprimento e pergunta sobre a urgência: "SAMU 192, Flor, bom dia, qual a sua urgência?”.

Questionados se eles estavam seguindo alguma recomendação, ou se usar pseudônimo era alguma norma daquele call center, todos responderam afirmativamente. Aprenderam com os colegas. Alguns nem se recordavam de quando começaram a utilizar esse artifício, que aparentemente representa um ritual de batismo, simbolicamente identificado na escolha de um novo nome.

Meu nome é Júlia, mas a maioria das pessoas aqui usa pseudônimo. E quando eu cheguei aqui já tinha uma pessoa que atendia como Júlia, aí eu bolei um nome (começou a rir) que fica fácil de eu lembrar [...]. É assim, eu nem sei por quê. Quando eu cheguei já era assim, tem gente que usa o próprio nome e tem gente que usa o nome que gostaria de usar. (Flor) 
Evidencia-se a presença do medo. Nesse caso, trata-se do risco de erro e de sofrer alguma consequência por ato do usuário do SUS contra sua integridade, contra sua vida, ou mesmo o medo da perda do emprego. Dessa forma, esse ritual não prescrito de batismo constitui uma nova identidade que preserva situações temerosas e protege $o$ trabalhador das ameaças.

Essa representação introduz uma identidade virtual, uma espécie de avatar, e se reflete no universo subjetivo do trabalhador, que busca mecanismos para anular o risco, seja simplesmente o ignorando ou o assumindo e buscando estratégias para sua autodefesa. Como todos praticam essa conduta, caracteriza-se então uma intersubjetividade típica de estratégia coletiva de defesa. (DEJOURS, 1991) Na medida em que o trabalhador tem a consciência de que esse risco se relaciona ao trabalho, que é compartilhado por seus pares, o sofrimento deixa de ser individual e as estratégias de defesa geram sentimento de cumplicidade protetora, explicada pela psicodinâmica do trabalho. Nota-se que durante a etapa de campo da pesquisa não se observou nenhum trabalhador utilizar o verdadeiro nome, porém isto pode eventualmente ocorrer.

Esta experiência no trabalho real vivida no SAMU já se encontra contemplada, do ponto de vista das normas de Estado. Indica-se que "as prescrições de diálogos de trabalho não devem exigir que o trabalhador forneça o sobrenome aos clientes, visando resguardar sua privacidade e segurança pessoal”. (BRASIL, 2007, p. [5]) A análise do trabalho revelou tal situação e mostrou sua importância e caráter singular. Essa questão ainda requer maiores discussões e estudos acerca da proteção dos trabalhadores de um lado e da adequada assistência à saúde dos usuários de outro, observando preceitos éticos que envolvem a ação de cuidar da saúde.

\section{Meio ambiente de trabalho, organização e condições de saúde}

Apesar da pouca expressividade do assunto constatada nas narrativas, o relato de casos de adoecimento emergiu das verbalizações dos trabalhadores:

Tive aquela síndrome de Burnout, que é aquela doença ocupacional que é do estresse de exaustão, e aí eu fiquei 15 dias afastada. (Dra. Vanessa) 
Sinto-me estressadíssima... fisicamente sinto muita dor, dor no corpo, eu estava com a cabeça estourando [...] de vez em quando eu sinto uma dor no ombro, nos ombros. (Flor)

As chamadas “dobras”, ou horas extras dobrando a jornada, são frequentes:

Nunca senti nada depois de um dia de trabalho, só estresse mesmo, não tem como, principalmente eu que dou 24 horas, antigamente podia dar 1000 horas, uma vez eu dei 72 horas. (Chaves)

É estressante esse trabalho, porque ficar 6 horas num telefone que não pára nunca... Seis horas na teoria. (Helena)

A fadiga e o estresse são expressos nas narrativas dos trabalhadores:

Cansaço psicológico! Tem dias que o plantão aqui é um pouco estressante, tem paciente que já te atende te xingando; a médica tá cheia de ocorrência e já reclama com a gente, então. (Dudu)

O conflito ilustrado no extrato da narrativa anterior trata do relacionamento entre o TARM e o Médico Regulador. Isto ocorre quando este se sente sobrecarregado de ligações encaminhadas seletivamente pelo TARM, enquanto outros médicos, no mesmo turno, não se disponibilizam para o trabalho. Esta situação desencadeia acusações e repreensões ao TARM, que evita responder ao médico e utiliza o silêncio como estratégia tanto do ambiente quanto do head-set, que podem estar associados a alterações somáticas, cefaleias, zumbidos nos ouvidos, seguidos de vertigens e náuseas.

Outra dificuldade encontrada pelo trabalhador é a de assumir uma doença, pois isso implica assumir um risco quanto à manutenção do emprego.

Porque se a gente assume, entra pra lista de corte, é uma questão de sobrevivência... Qualquer coisa eu digo que é TPM [...] eu já vi gente aqui ficando tempo longe por causa de inflamação no ouvido. LER, teve uma colega nossa aqui que pegou. (Helena)

Demandas excessivas de ordem psíquica, como conflitos originários do trote, revelam uma organização do trabalho com riscos para a saúde do trabalhador. Nesse sentido, a central de regulação médica do SAMU 192 não se distancia muito das outras centrais de teleatendimento quando se trata das possibilidades de adoecimento. 
Outra característica considerada nociva ao trabalhador foi a constatação do uso frequente das “dobras”. A NR 17 e o Artigo 61 da Consolidação das Leis do Trabalho (CLT) trazem que o prolongamento do horário só pode acontecer em casos excepcionais sem ultrapassar às 36 horas semanais previstas. (BRASIL, 2007)

Os trabalhadores na Central de Regulação Médica do SAMU 192 se declaram, em geral, saudáveis. Relatam que foram poucos os casos de afastamento por doenças relacionadas ao trabalho. O SAMU tem menos de seis anos de funcionamento e muitos trabalhadores têm relativamente pouco tempo de trabalho na instituição.

A demanda de tempo para o trabalho em call centers, de modo geral, é definida pela produtividade em função do lucro, com características de uma organização de trabalho taylorista-fordista. (MOCELIN; SILVA, 2008) Porém, no caso do Samu, em função de pertencer à estrutura de serviço do SUS, esse mesmo tempo que dita o trabalho, representa a vida ou a morte de outro. $\mathrm{O}$ ritmo de trabalho não é definido pelo capital, mas sim pela função pública de proteção à saúde como dever do estado.

Insere-se neste bojo uma questão paradoxal, segundo Jackson Filho e Assunção (2006, p. [2]), em que “[...] as formas de organização existentes nos serviços de teleatendimento, cujos modos de gestão são voltados para impedir o desenvolvimento da inteligência, da emoção, da sociabilidade humanas em atividades de trabalho" se contrapõem às próprias características desse trabalho, onde o teleatendente, ou TARM, necessariamente tem na interação humana característica sine qua non no seu contexto laboral. As tarefas inscritas na organização do trabalho do TARM estão pautadas em regras do trabalho encontradas nos serviços de telemarketing em geral, a exemplo do controle rígido de tempo, porém apresentam particularidades e condutas flexíveis. Entretanto, nesse contexto persistem excessos de cargas de trabalho e situações conflituosas internas ao serviço e na relação com usuário que se configuram em riscos à saúde.

A presença do controle comportamental em função das emoções foi uma condição latente nos resultados das observações. Esse controle é de natureza pessoal, condicionado pelo sistema técnico e pela delicadeza da demanda de situação de urgência. Significa que o TARM deve conter, expressar ou eliminar emoções em cada caso atendido, conforme observado nas verbalizações: "Esse me chamou de lerda! Vamos ver o que será que temos 
mais para hoje”. (Flor) É competência do TARM também intervir no quadro emocional do solicitante, de modo a gerir simultaneamente sua própria emoção e a do usuário, enquanto instrumento de trabalho, semelhante ao verificado em outros serviços de telemarketing. (PENA; CARDIM; ARAÚJO, 2011)

Ainda sobre aspectos emocionais, Vilela e Assunção (2004, p. 1071) afirmam que "[...] a natureza da atividade solicita habilidade em contornar situações difíceis e inusitadas [...]”. Por tais razões indicam as necessárias pausas quando momentos de conflito acontecem, sendo ele participante do conflito ou mediador, o que é constante em sua função. A NR 17, anexo II, garante ao trabalhador um tempo para que ele se recupere e consiga socializar os conflitos que porventura possam vir a ocorrer, como ameaças, abuso verbal, agressões, ou situações desgastantes. (BRASIL, 2007)

\section{Considerações finais}

Por meio deste estudo, foi possível conhecer o trabalho em uma central de regulação médica do SAMU 192. Através de uma perspectiva centrada no trabalho do TARM foram desvendadas e descritas as relações existentes, desmistificando algumas situações, e revelando estratégias adotadas pelos trabalhadores para viabilizar a execução das suas tarefas, como as adotadas para identificação do trote e o disparo automático nas urgências. Os ciclos de atendimento do TARM e sua interação com os usuários do serviço evidenciaram alta demanda de trote, sobrecarregando o trabalhador; além das chamadas por engano ou para orientação. Esta sobrecarga pode trazer consequência para a saúde do trabalhador e distanciam o esforço institucional do objeto de ação do serviço de urgência. Descortinou-se ainda uma modalidade de batismo cibernético com o uso de pseudônimo como estratégia de proteção coletiva diante da possibilidade de violência de usuário descontente. Essas condições presentes nas novas práticas da modalidade da telemedicina tornaram-se conhecidas a partir da análise realizada que permitiu conhecer melhor essa realidade pouco estudada.

A melhoria do software pode ser central para redução do desgaste dos TARM. Tal ferramenta poderia contemplar um sistema interativo de alertas ao trote, evitar o excesso de procedimentos repetitivos na jornada, melhorando sua navegabilidade, dentre outras modalidades similares, além de 
sugestões de pausas para descanso ou recuperação, principalmente após chamadas mais demandantes dos aspectos emocionais do trabalhador. Para isso, a participação do trabalhador no processo de reengenharia dessa ferramenta é imprescindível.

Além das medidas técnicas relacionadas aos fundamentos ergonômicos aplicados às pessoas que utilizam o sistema informático, em se tratando do trote, percebe-se a necessidade de ampliar ações para campanhas educativas junto à população, informando sobre as repercussões e desdobramentos desse tipo de acometimento e prejuízos de ordem material e humana. A constituição de legislação específica envolvendo medidas disciplinadoras e punitivas tem sido uma tendência que pode complementar a redução desse fenômeno social perverso.

Apesar das limitações metodológicas e da necessidade de novos estudos sobre o call center em serviços públicos como o SAMU, o presente estudo indicou aspectos críticos da organização do trabalho por meio das observações e expressos nas narrativas. Nesse contexto, a satisfação do trabalhador com a tarefa do cuidado e atendimento à urgência aparece como uma possível proteção, amenizando os efeitos das condições laborais decorrentes da produção de um serviço pautada pela tensão ao lidar com situações delicadas e limítrofes entre vida ou morte dos usuários do sistema SUS.

A melhoria nas condições gerais de trabalho destes profissionais beneficiará sua saúde e possibilitará o crescimento da qualidade no atendimento ao usuário do SUS, que pode se refletir em aumento da eficiência dos atendimentos, salvando mais vidas.

\section{Referências}

ABRAHÃO, J. I.; SILVINO, A. M. D.; SARMET, M. M. Ergonomia, cognição e trabalho informatizado. Psicologia: teoria e pesquisa, Brasília, v. 21, n. 2, p.163-171, maio/ago. 2005 .

ABRAHÃO, J. I.; TORRES, C. C. Entre a organização do trabalho e o sofrimento: o papel de mediação da atividade. Revista Produção, São Paulo, v. 14, n. 3, p. 67-76, set./dez. 2004 .

ANDRADE, A. P. et al. Perfil da assistência do serviço de atendimento móvel de urgência no ano de 2008 no município de Sobral, Ceará. SANARE: Revista de Políticas Públicas, Sobral, v. 9, n. 1, p. 61-63, jan./jun. 2010. 
ASSOCIAÇÃO BRASILEIRA DE TELESSERVIÇOS - ABT. Página de abertura. 2011. Disponível em: <http://www.abt.org.br>. Acesso em: 5 fev. 2011.

ASSUNÇÃO, A. A. et al. Abordar o trabalho para compreender e transformar as condições de adoecimento na categoria dos teleatendentes no Brasil. Revista Brasileira de Saúde Ocupacional, São Paulo, v.31, n. 114, p. 47-62, jul./dez. 2006. Disponível em: <http://www.scielo.br/pdf/rbso/v31n114/o5.pdf>. Acesso em: 5 jan. 2011.

ASSUNÇÃO, A. A.; SOUZA, R. J. Telemática. São Paulo: INST/CUT, 200. (Cadernos de Saúde do Trabalhador).

BAHIA. Secretaria de Saúde do Estado da Bahia. Regula Saúde: projeto de reorganização do atendimento de Urgências e emergências para o estado da Bahia. Salvador, 2010.

BOUTET, J. A atividade do trabalho nas centrais de atendimento: um trabalho de linguagem. Revista Brasileira de Saúde Ocupacional, São Paulo, v. 31, n. 114, p. 73-82, jul./dez. 2006.

BRASIL. Decreto-Lei n ${ }^{\circ} 5 \cdot 45^{2}$, de $1^{\circ}$ maio de 1943. Aprova a Consolidação das Leis do Trabalho. Diário Oficial [da] República Federativa do Brasil, Brasília, DF, 1943. Disponível em: <https://www.planalto.gov.br/ccivil_o3/decreto-lei/ Del5452.htm>. Acesso em: 5 ago. 2010.

BRASIL. Ministério da Saúde. Portaria n 2.657, de 16 de dezembro de 2004. Estabelece as atribuições das centrais de regulação médica de urgências e o dimensionamento técnico para a estruturação e operacionalização das Centrais SAMU-192. Diário Oficial [da] República Federativa do Brasil, Brasília, DF, 2004. Disponível em: <http://bvsms.saude.gov.br/bvs/saudelegis/gm/2004/ prt2657_16_12_2004.html>. Acesso em: o8 dez.2017.

BRASIL. Ministério do Trabalho e Emprego. Anexo II da NR-17. Estabelece parâmetros mínimos para o trabalho em atividades de teleatendimento/ telemarketing nas diversas modalidades desse serviço, de modo a proporcionar um máximo de conforto, segurança, saúde e desempenho eficiente. Diário Oficial [da] República Federativa do Brasil, Brasília, DF, 2007. Disponível em: <http:// trabalho.gov.br/images/Documentos/SST/NR/NR17-ANEXO2.pdf>. Acesso em: 13 dez. 2017.

BRASIL. Ministério do Trabalho e Emprego. CBO - Classificação Brasileira de Ocupações. 2010. Disponível em: < http://www.mtecbo.gov.br/cbosite/pages/ home.jsf $>$. Acesso em: 5 ago. 2010. 
CALDERÓN, J. A. El sentido de lo público en el trabajo a prueba de la restructuración productiva: el caso de los centros de llamadas. Revista Brasileira de Saúde Ocupacional, São Paulo, v. 31, n. 114, p. 19-34, jul./dez. 2006.

CASTRO, I. S. et al. Diferenças interindividuais em teleatendimento de emergências: explicitação por meio da entrevista de autoconfrontação. Revista Brasileira de Saúde Ocupacional, São Paulo, v. 31, n. 114, p. 83-96, jul./dez. 2006.

DANIELLOU, F. (Coord.). A ergonomia em busca de seus princípios: debates epistemológicos. São Paulo: Edgard Blücher, 2004.

DEJOURS, C. A loucura do trabalho: estudo de psicopatologia do trabalho. 4. ed. São Paulo: Cortez, 1991.

GUÉRIN, F. et al. Compreender o trabalho para transformá-lo: a prática da ergonomia. São Paulo: Blucher, 2001.

JACKSON FILHO, J. M.; ASSUNÇÃO, A. A. Trabalho em teleatendimento e problemas de saúde. Revista Brasileira de Saúde Ocupacional, São Paulo, v. 31, n. 114, p. 19-34, jul./dez. 2006. Disponível em: <http://www.redalyc.org/articulo. oa? $\mathrm{id}=100517072001>$. Acesso em: 13 dez. 2017.

KAFURE, I. El proceso creativo de la interfaz del sistema de gestión de la información. Revista Interamericana de Bibliotecología, Medellín, vol. 33, n. 1., p, 169-186, enero/jun. 2010. Disponível em: <http://repositorio.unb.br/ handle/10482/5865>. Acesso em: 5 ago. 2010.

LIMA, F. P. A. A ergonomia como instrumento de segurança e melhoria das condições de trabalho. In: SIMPÓSIO BRASILEIRO SOBRE ERGONOMIA E SEGURANÇA DO TRABALHO FLORESTAL E AGRÍCOLA (ERGOFLOR), 1., 200o, Belo Horizonte. Anais... Viçosa: Universidade Federal de Viçosa, 200o. p. 1-11.

MARQUEZE, E. C.; MORENO, C. R. C. Satisfação no trabalho - uma breve revisão. Revista Brasileira de Saúde Ocupacional, São Paulo, v. 3o, n. 112, p. 69-79, jul./dez. 2005. Disponível em: <http://www.scielo.br/pdf/rbso/v3on112/o7.pdf>. Acesso em: 5 ago. 2010.

MINAYO, M. C. S. O desafio do conhecimento: pesquisa qualitativa em saúde. 12. ed. São Paulo: Hucitec, 2010.

MOCELIN, D. G; SILVA, L. F. S. C. O telemarketing e o perfil sócio-ocupacional dos empregados em call centers. Caderno CRH, Salvador, v. 21, n. 53, p. 365-387, maio/ago. 2008 .

MOLINIER, P. Psicodinâmica do trabalho e relações sociais de sexo: um itinerário interdisciplinar: 1988-2002. Revista Produção, v. 14, n.3, p.14-26, set./ dez. 2004. 
OLIVEIRA, S.; JACQUES, M. G. C. Políticas e práticas de gestão e saúde: recortes sobre o trabalho de teleatendimento no Rio Grande do Sul. Revista Brasileira de Saúde Ocupacional, São Paulo, v.31, n.114, p. 63-72, jul./dez. 2006.

OLIVEIRA, S.; REZENDE, M. S.; BRITO, J. Saberes e estratégias dos operadores de telemarketing frente às adversidades do trabalho. Revista Brasileira de Saúde Ocupacional, São Paulo, v. 31, n. 114, p. 125-134, jul./dez. 2006.

PAIVA, K. C. M.; AVELAR, V. L. L. M. Qualidade de vida no trabalho em uma central de regulação médica de um serviço de atendimento móvel de urgência (SAMU). Organizações e Sociedade, Salvador, v. 18, n. 57, p. 303-321, abr./jun. 2011.

PALÁCIOS, M.; DUARTE, F.; CÂMARA, V. M. Trabalho e sofrimento psíquico de caixas de agências bancárias na cidade do Rio de Janeiro. Cadernos de Saúde Pública, Rio de Janeiro, v. 18, n.3, p. 843-851, maio/jun. 2002.

PARAGUAY, A. I. B. B. Da organização do trabalho e seus impactos sobre a saúde dos trabalhadores. In: MENDES, R. (Org.). Patologia do Trabalho. 2. ed. São Paulo: Atheneu, 2005. p. 811-823.

PENA, P. G. L.; CARDIM, A.; ARAÚJO, M. P. N. Taylorismo cibernético e lesões por esforços repetitivos em operadores de telemarketing em Salvador-Bahia. Caderno CRH, Salvador, v. 24, p. 131-153, 2011. Suplemento 1.

REZENDE, D. A. Engenharia de software e sistemas de informação. 3. ed. Rio de Janeiro: Brasport, 2005.

RICCI, M. G.; RACHID, A. A organização do trabalho em serviços: um estudo sobre o teleatendimento. Revista Eletrônica Produção \& Engenharia, Juiz de Fora, v. 3, n. 1, p. 224-235, jan./jun. 2013 .

RIO DE JANEIRO (Estado). Assembleia Legislativa. Projeto de Lei $n^{\circ}$ 1483/2012. Dispõe sobre medidas contra a prática de trotes telefônicos dirigidos aos órgãos que especifica. 2012. Disponível em: <http://alerjln1.alerj.rj.gov.br/scpro1115.nsf/ dde654f2fb348o6783256ceeoo589oed/bdg6f3bbef859444832579eboo64993f?O penDocument\&ExpandSection=-1>. Acesso em: 5 maio 2013 .

SVENSSON, M. Routes, routines and emotions in decision making of emergency call takers. 2012.355 f. Dissertation (Doctoral in Industrial Economics and Management) - School of Management, Blekinge Institute of Technology, Sweden, 2012. (Blekinge Institute of Technology doctoral dissertation series, $\mathrm{n}$. 2012:04).

THIRIÓN, J. M. Los call centers y los nuevos trabajos del siglo XXI. CONfines de relaciones internacionales y ciencia política, Nuevo León, v. 3, n. 5, p. 49-58, enero/ mayo 2007 . 
TORRES, C. C.; ABRAHÃO, J. I. A atividade de teleatendimento: uma análise das fontes de prazer e sofrimento no trabalho. Revista Brasileira de Saúde Ocupacional, São Paulo, v. 31, n. 114, p. 113-124, jul./dez. 2006.

VENCO, S. Centrais de atendimento: a fábrica do século XIX nos serviços do século XXI. Revista Brasileira de Saúde Ocupacional, São Paulo, v.31, n. 114, p.7-18, jul./dez. 2006.

VILELA, L. V. O.; ASSUNÇÃO, A. A. Os mecanismos de controle da atividade no setor de teleatendimento e as queixas de cansaço e esgotamento dos trabalhadores. Cadernos de Saúde Pública, Rio de Janeiro, v. 2o, n. 4, p. 1069-1078, jul./ago. 2004 .

WISNER, A. A inteligência no trabalho: textos selecionados de ergonomia. Tradução de Roberto Leal Ferreira. São Paulo: FUNDACENTRO, 1994.

WISNER, A. Atividades humanas previstas, atividades humanas reais nos sistemas automatizados. In: SEMINÁRIO INTERINSTITUCIONAL “TRABALHO, TECNOLOGIA \& ORGANIZAÇÃO”, 1., 1996, Belo Horizonte. Anais... Belo Horizonte: UFMG: Escola de Engenharia, 1996. p. 1-16. 


\title{
Conflitos e estratégias dos trabalhadores de enfermagem na emergência de uma maternidade pública
}

\author{
MANOEL HENRIQUE DE MIRANDA PEREIRA \\ PAULO GILVANE LOPES PENA \\ RITA DE CÁSSIA PEREIRA FERNANDES
}

\section{Introdução}

A dinâmica do trabalho nos serviços de urgência e emergência tem sido condicionada pela constante superlotação, impondo ritmo acelerado e sobrecarga para os trabalhadores. O trabalho em saúde é caracterizado pela produção não material, sendo o produto indissociável do processo que o produz, pois acontece no ato de sua realização.

No cotidiano do trabalho, a tarefa de prestar cuidados diretos e ininterruptos expõe os trabalhadores de saúde a riscos e acidentes ocupacionais. (ALEXANDRE, 2007; BARBOZA, 2003; BRITO, 2011; CANINI et al., 2002) A enfermagem representa a maior força de trabalho no Sistema Único de Saúde (SUS), o que corresponde a aproximadamente 1,4 milhão de trabalhadores, $90 \%$ são mulheres, apesar da tendência crescente de homens na profissão. (MACHADO; VIEIRA; OLIVEIRA, 2012) Leila Dotto, Marli Mamede e Fabiana Mamede (2008) identificaram em estudo realizado em 
duas maternidades que $73,6 \%$ dos registros de acidentes de trabalho foram com auxiliares, técnicos de enfermagem e enfermeiros e Balsamo e Felli (2006) detectaram que os setores de emergência são o local com maior percentual desses acidentes.

Estudo com profissionais de enfermagem que atuam em unidade de emergência demonstrou que estresse, cansaço, esgotamento e frustração fazem parte do cotidiano de trabalho. Privação do sono, extensas jornadas de trabalhos, múltiplos vínculos de emprego, atividade sobpressão temporal e déficit de trabalhadores são aspectos presentes no contexto ocupacional dessa categoria. (SALOMÉ; MARTINS; ESPÓSITO, 2009) O fato de serem mulheres as torna mais vulneráveis às agressões.

$\mathrm{Na}$ atenção materno-infantil, há problemas no acesso aos serviços de saúde com a peregrinação de mulheres gestantes na rede de atenção em busca de vagas na assistência pré-natal, para realização de exames e no momento do parto nas maternidades. A constante superlotação dos serviços que realizam partos e a precariedade das condições de trabalho dos servidores representam aspectos preocupantes frente à necessidade de prestar uma assistência com qualidade.

A organização da assistência ao nascimento deve estar voltada para satisfazer os interesses da mulher e da família através de apoio constante dos trabalhadores, o que pressupõe maior integração entre esses. Neste sentido, o primeiro contato entre a mulher e o profissional durante o parto assume importância fundamental: dessa dinâmica emerge a construção das primeiras impressões positivas ou negativas sobre os trabalhadores e a assistência.

A identificação das condições e dos meios para a realização do trabalho no setor de admissão de uma maternidade pública e o modo como os trabalhadores de enfermagem lidam no cotidiano do trabalho conforma problemas de investigação sobre os quais este estudo se debruça. Nessa perspectiva, objetiva-se descrever as características do trabalho das enfermeiras e técnicas de enfermagem e identificar os aspectos associados à saúde dessas trabalhadoras.

\section{Métodos}

Este estudo foi desenvolvido em uma maternidade pública localizada na periferia da cidade do Salvador. É considerada referência secundária para 
gestação de alto risco, recebendo gestantes com maior gravidade de todo o Estado. Inaugurada na década de 1990, dispõe de 51 leitos de internamento, oito macas de observação no setor de admissão da emergência e dez leitos de unidade intermediária neonatal, ofertando ações de pré-natal e saúde da criança em seu ambulatório. Inicialmente, foram realizadas cinco visitas técnicas e entrevistas individuais não estruturadas com diretores e coordenadores da maternidade com o objetivo de aproximação ao campo de estudo. Entre janeiro e novembro de 2012, realizaram-se 15.835 atendimentos na admissão com aproximadamente 47 atendimentos por dia. Neste período, obteve $96 \%$ de taxa de ocupação e 3,4 dias de média de permanência dos leitos ocupados, o que indica que funcionou com quase toda sua capacidade. Realizam-se 3.469 partos, sendo 2.232 partos naturais e 1.237 cesáreas, com média mensal de 289 partos e $28 \%$ de taxa de cesárea.

Antes de iniciar as observações, os trabalhadores foram informados dos objetivos da pesquisa, houve a explicação sobre o método utilizado, exposta a necessidade de permanência do pesquisador no ambiente de trabalho e que perguntas seriam feitas a qualquer momento, sendo ressaltada a participação voluntária e preservada a identificação dos participantes. Todos os entrevistados assinaram o Termo de Consentimento Livre e Esclarecido (Anexo 1), e esta pesquisa foi aprovada pelo Comitê de Ética em Pesquisa (CEP) da Escola de Enfermagem da Universidade Federal da Bahia (EEUFBA). A coleta de dados teve início em agosto de 2012 e foi concluída em dezembro do mesmo ano.

Utilizou-se a Análise Ergonômica do Trabalho (AET), enquanto abordagem metodológica das situações concretas de trabalho, buscando situar a atividade de trabalho de enfermeiras e técnicas de enfermagem no contexto de funcionamento do setor de admissão da emergência. $\mathrm{O}$ método pressupõe a análise das tarefas e da atividade. Para Laville (1977), esses conhecimentos permitem atuar sobre os elementos constitutivos das condições de trabalho (fisiológicos, psicológicos, sociais, econômicos e técnicos). Schwartz (2010, p. 36) diz que, "para compreender o trabalho, os saberes disciplinares são necessários, mas é com aqueles que trabalham que se validará conjuntamente o que podemos dizer da situação que eles vivem”.

A AET pode permitir aproximações entre a complexidade e a multiplicidade de fatores que interagem nas situações de trabalho. (ABRAHÃO; PINHO, 2002) Daniellou (2004) lembra que é necessário ir além da pres- 
crição do trabalho, é preciso dar visibilidade à construção do processo de gestão singular e coletiva de saberes, valores e regras com as quais o trabalhador compõe seu trabalho no cotidiano.

A AET utiliza como conceitos centrais: trabalho real ou atividade e trabalho prescrito ou tarefa. O trabalho prescrito refere-se ao "que se deve fazer", está no campo do que se espera ser realizado pelo trabalhador no âmbito do processo laboral. Neste caso, a definição das tarefas é estabelecida de modo antecipado à ação propriamente dita e em condições pré-determinadas. As ordens emitidas pela hierarquia, sejam elas oral ou escrita, protocolos, normas técnicas e de segurança, meios técnicos colocados à disposição, formas de divisão de trabalho e condições temporais previstas, qualificação profissional e o salário, situam-se no campo da prescrição. (GUÉRIN et al., 2001)

A tarefa é concebida no exterior da atividade, antecede o trabalho propriamente realizado, conserva relação de predição sobre o tempo, o que determina e restringe a própria atividade. Schwartz (2010) defende que as restrições "exigem" do trabalhador fazer de outra forma, recriar de modo permanente sua situação de trabalho. Promovem também o deslocamento do trabalho, no qual a atividade desenvolvida se constitui em estratégia de adaptação do trabalhador à situação real de trabalho. Portanto, a atividade ou trabalho real é a ação realizada pelo trabalhador nas condições e no ambiente real de trabalho e materializam-se como o modo que o trabalhador lida com os objetivos e meios disponíveis. (GUÉRIN et al., 2001) Para Schwartz (2010) trabalhar envolve gerir em permanente processo de negociações entre normas antecedentes e renormalizações parciais para alcançar os meios de realizar a tarefa e a manutenção da saúde. As normas não incluem os incidentes, as operações improvisadas necessárias à execução da tarefa e as variações que ocorrem no curso das atividades orientadas pelos imprevistos. Para entender o trabalho, é necessário observar e analisar o desenrolar do fazer nas situações reais, identificando o que muda e o que faz o trabalhador tomar decisões frente aos problemas recorrentes do cotidiano. As condições previstas se distanciam do contexto real do cotidiano, do mesmo modo que o resultado antecipado não é necessariamente o resultado alcançado.

O trabalho real e o prescrito não estão em oposição, mas se articulam por meio das situações vividas pelos trabalhadores, nas quais há a experiência constante de lidar com as contradições e conflitos entre as normas que ante- 
cedem o trabalho e os contextos reais da atividade. No trabalho, acontece o ajustamento entre a tarefa e a situação concreta, cabendo ao trabalhador criar estratégias, não se restringindo a mero executor da tarefa. Esse é sujeito ativo e, portanto, à medida que é confrontado com as dificuldades do trabalho, elabora estratégias e diferentes modos operatórios com o objetivo de regular as restrições e obter os resultados. A atividade de trabalho é o componente estruturante nas situações, conformando-se enquanto resposta às restrições colocadas ao trabalhador. A atividade é constituída em situação mediante a inter-relação dos componentes que conformam o próprio trabalho.

A atividade resulta da dinâmica entre a variabilidade organizacional e as regulações que os profissionais desenvolvem para dar conta de suas metas. Nas condições reais, existem variações do processo de trabalho resultantes das variações na natureza da demanda e seu volume, nos equipamentos e no ambiente. Essas se relacionam às características do próprio trabalhador, definidas como variabilidade intraindividual relativas aos seus aspectos físicos, psíquicos e cognitivos. Diante dessas variabilidades, os trabalhadores elaboram diferentes modos operatórios, levam em conta os meios disponíveis, em constante "fazer de outro jeito", que é mobilizado para cumprir os objetivos ou mesmo para se poupar das restrições presentes nas situações.

A AET se estrutura em técnica de observação e o estatuto da fala é de complementaridade ao observado. A pesquisa fez uso de observação participante, com tempo total de observação das situações de trabalho de 96 horas, sendo quatro plantões diurnos - de $7 \mathrm{~h}$ às $19 \mathrm{~h}$ - e quatro plantões noturnos - de $19 \mathrm{~h}$ às $7 \mathrm{~h}$. Em um desses plantões, a observação aconteceu durante 24 horas ininterruptas, com o intuito de identificar elementos de continuidade ou descontinuidade nas atividades do setor de admissão na troca de plantões. A fase da observação das situações de trabalho foi precedida da análise do funcionamento da maternidade onde foram estudadas normas, rotinas e condutas relacionadas à atividade da equipe de enfermagem do setor de admissão. Antecedendo a etapa de análise do processo e das tarefas, ainda na exploração do funcionamento da maternidade, foram utilizados como fontes documentais os relatórios de gestão de 2011 e 2012.

Durante as observações, foi utilizada a técnica da entrevista situada, em que o pesquisador provoca a verbalização dos trabalhadores no ato em que a tarefa é executada. Questões referentes às situações de risco à saúde emergiram do contexto laboral observado e fizeram parte da comunicação entre 
pesquisador e trabalhadoras. As trabalhadoras livremente fizeram perguntas ao pesquisador e quando uma situação as mobilizava elas falavam sobre ela e essas verbalizações espontâneas e provocadas foram sendo registradas.

Durante o curso da tarefa, perguntas de confrontação foram feitas às trabalhadoras sobre "o porquê estavam fazendo daquele jeito?'. Essa confrontação teve como objetivo identificar e esclarecer eventuais contradições postas na atividade, além de potencializar a explicitação da singularidade da experiência colocada em circulação no interior da atividade. Houve necessidade de, após a análise das entrevistas, retornar para alguns entrevistados para esclarecer alguns aspectos.

Ao final do plantão ou durante seu curso, alguns trabalhadores eram convidados a participar de entrevistas utilizando roteiro estruturado. Como critérios de seleção para as entrevistas, foram utilizados: a) disponibilidade em participar da entrevista; b) ser enfermeira, técnica de enfermagem ou obstetra; c) maior tempo de lotação no setor de admissão; e d) maior interação com o pesquisador durante as entrevistas situadas. Participaram dessas entrevistas duas obstetras, duas enfermeiras e duas técnicas de enfermagem. O número de entrevistas com roteiro estruturado foi condicionado pela disponibilidade das trabalhadoras. As entrevistas tiveram uma duração média de quarenta minutos e as perguntas foram guiadas pelo roteiro formulado durante a fase exploratória e observacional do estudo. Esse roteiro trouxe como perguntas, além daquelas de identificação ocupacional das entrevistadas, função na maternidade, vínculo de emprego, tempo de formação, experiências profissionais, tempo na função, as questões: a) O que está descrito pela instituição sobre as suas atribuições? b) Qual a sua rotina de trabalho na admissão? c) Quando você chegou, alguém explicou a você ou você teve acesso às rotinas? d) Em sua opinião, quais são as dificuldades para execução do seu trabalho na emergência?

\section{Resultados e discussões}

\section{O funcionamento do setor de admissão}

O regime de trabalho no setor de admissão é de 12 horas que correspondem a um plantão. Eventualmente, há troca de plantões entre os trabalhadores, o que pode significar o trabalho ininterrupto durante 24 horas. 
A maternidade possui 485 trabalhadores, desses, 33 são enfermeiras e 144 técnicas de enfermagem, em sua quase totalidade do sexo feminino. O serviço de emergência conta com quatro enfermeiras e 16 técnicas de enfermagem, das quais duas enfermeiras e 10 técnicas de enfermagem participaram do estudo. A média de idade do grupo é de 46 anos. $\mathrm{O}$ tempo de atividade ocupacional variou entre 7 e 34 anos, apenas duas trabalhadoras possuíam menos de dois anos de trabalho na maternidade e três estão no serviço desde sua inauguração. Todas pertencem ao quadro efetivo do Estado, sendo algumas delas com pouco tempo de vinculo público e sem experiência anterior em maternidade.

A maternidade, objeto deste estudo, presta assistência à gestação de risco para mulheres residentes em Salvador e interior do Estado. É o único serviço de emergência obstétrica da região em que está inserida e sua maior demanda é de pessoas residentes no seu entorno. A falta de acesso ao acompanhamento de pré-natal na atenção básica faz com que mulheres procurem atendimento no setor de emergência. Em muitos casos referem ou simulam dor, perda de líquido ou outro sintoma para possibilitar atendimento, conforme verificado neste estudo.

Nos plantões, foi constante a situação de superlotação dos leitos no setor de admissão. Esse contexto revela a saturação do limite operacional do setor de admissão, que segundo Weiss e colaboradores (2004), apresenta como indicadores de superlotação: $100 \%$ de ocupação dos leitos; pacientes nos corredores por causa da falta de leitos disponíveis; não recebimento de ambulâncias em razão da saturação operacional; sala de espera para consulta médica lotada; equipe do setor subjetivamente no limite da exaustão e mais de uma hora de espera para o atendimento médico.

A assistência na maternidade acontece nos setores: admissão da emergência, que atende diretamente à demanda externa; centro obstétrico com pré-parto e salas de cirurgia, onde são realizados os partos naturais e realizadas as intervenções cirúrgicas; unidade neonatal para assistência aos recém-nascidos com complicações e as enfermarias para mulheres e recém-nascidos em acompanhamento.

Durante as observações, foi percebido que o número maior de atendimentos ocorre durante os plantões diurnos e nos dias de semana. Foram comuns situações em que mulheres eram avaliadas após longo tempo de espera, em média seis horas após sua chegada, e algumas delas entraram 
em trabalho de parto na recepção da emergência, algumas antes de serem avaliadas pelo profissional do setor de admissão. $\mathrm{O}$ excesso de demanda tem prolongado o tempo de espera das mulheres, o que dificulta o acesso nos casos considerados de risco. A imprevisibilidade da demanda esteve relacionada ao fato do parto ser considerado evento de urgência e emergência obstétrica, o que caracterizou a variabilidade no trabalho no setor de admissão.

$\mathrm{O}$ atendimento no setor de admissão da emergência se inicia com a entrega da ficha de pronto atendimento (PA) e termina com o atendimento que pode resultar em liberação da mulher para alta ou internação com encaminhamento para os outros setores. No setor de admissão, realiza-se a primeira avaliação obstétrica para o rápido seguimento do cuidado, em uma dinâmica de alta rotatividade de seus leitos.

Figura 1 - Fluxograma de atendimento no setor de admissão da emergência

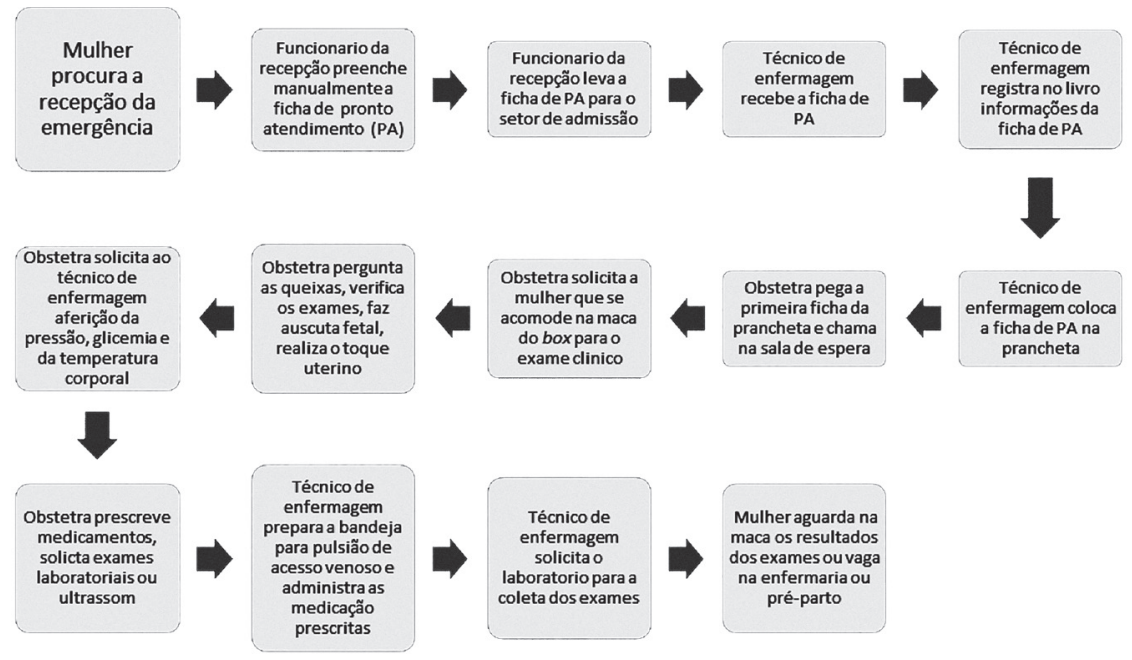

Fonte: elaborada pelos autores.

Durante as observações, o tempo de espera foi de quatro a oito horas, e a demora fez, algumas vezes, com que mulheres desistissem do atendimento. A insatisfação gerou conflitos com os funcionários da recepção e trabalhadoras do setor de admissão, fazendo com que mulheres e familiares adentrassem a admissão dizendo: "Quando serei atendido?", “Minha mulher está sangrando!”, “Vai demorar muito?’. Essas situações causavam tensão e 
insegurança nas trabalhadoras, e, em alguns casos, foram acompanhadas de agressão verbal pelos usuários. Em outras situações, ainda que a indagação tivesse ocorrido de modo cordial, houve reação das trabalhadoras gerando atrito com as pessoas que aguardavam atendimento.

Importa ressaltar que a violência em função de conflitos entre pacientes e profissionais de enfermagem tem sido relatada na literatura. Contrera-Moreno, Monteiro e Esposito (2002), analisando as comunicações de acidente de trabalho de serviços de saúde no ano 2000, identificou que 3,9\% dos acidentes de trabalho foram provenientes de agressão física provocada por pacientes. No Canadá, durante o período de dois anos foram registrados 242 casos de agressão física e 646 registros de agressões verbais. Os trabalhadores de enfermagem foram os que mais sofreram agressões com $80,2 \%$ dos registros. (YASSI, 1994)

Trabalhadores de outros setores também executam atividades no setor de admissão, a exemplo da copeira e nutricionista que fazem a distribuição das refeições das mulheres e o funcionário do laboratório que realiza as coletas de sangue. Existe uma cadeia de dificuldades de que emerge em função da superlotação dos leitos do setor de admissão. Quanto maior o número de mulheres internadas, maior é a circulação de outros trabalhadores, o que significa perturbações no processo de trabalho da equipe.

Todos os boxes possuem equipamentos que são usados na avaliação obstétrica, como sonares para ausculta fetal, luvas e vaselina para a realização do toque vaginal. $\mathrm{O}$ atendimento de gestantes consideradas de alto risco está previsto para acontecer no box adaptado com monitor multiparamétrico, porém durante as observações esse equipamento permaneceu desligado. Nas entrevistas, ao confrontar essa situação com algumas trabalhadoras, foi relatado que o equipamento não estava funcionando por motivo de quebra e que até o momento não havia sido consertado. $\mathrm{O}$ box 4 foi adaptado para avaliação de recém-nascidos, nesses casos as técnicas de enfermagem chamam o neonatologista do plantão por telefone, esse profissional se desloca das unidades de cuidado intensivo neonatal ou do centro obstétrico, o que quase sempre representa demora no atendimento em atender ao chamado do setor, permanecendo a criança e a mãe no box da admissão.

O espaço dos boxes é dividido para o atendimento de duas mulheres, tornando difícil manter a privacidade, por isso cada mulher entra sozinha, o 
que contraria a normativa federal que versa sobre o direito de acompanhante para mulheres grávidas em atendimento, além de representar aumento para as mulheres do medo, angustia e insegurança, sentimentos que interferem no curso seguro do trabalho de parto. Na chegada à emergência da maternidade não há rotina de orientação e esclarecimentos às mulheres e familiares. O excesso de demanda e a demora prejudicam o atendimento das mulheres no tempo oportuno e dificulta o trabalho no setor de admissão da maternidade, condicionando as citadas situações de conflito.

Algo que chamou a atenção foi o fato de, ao iniciar a avaliação, alguns profissionais, ao se dirigir às mulheres, utilizavam quase sempre a frase “deite e tire a calcinha!”. Frases pronunciadas de modo quase automático, sem explicação às mulheres sobre o procedimento a ser realizado. $\mathrm{O}$ trabalho era assim direcionado para a realização do procedimento, desconsiderando modos de fazer que conduzissem a práticas mais humanizadas.

Aliado ao excesso de demanda foi observada ocorrência de "falas mecanizadas”, ações padronizadas que evidenciavam racionalidade ligada à produção de ações em massa, similar ao que acontece numa linha de montagem. Em pesquisa sobre a ocorrência de violência institucional em maternidades, a Fundação Perseu Abramo (2010) verificou que um a cada quatro nascimentos em hospitais públicos ou privados existiu algum tipo de agressão durante o parto. Entre as modalidades de violência estão o exame de toque doloroso, negativa para alívio da dor, não explicação para procedimentos adotados, gritos de profissionais ao realizar o atendimento, negativa de atendimento e xingamentos ou humilhações.

No cenário de precárias condições de trabalho, com indução a práticas mecanicistas e que desconsideram um cuidado humanizado, na tentativa de superar os limites impostos pela organização do trabalho, as trabalhadoras do setor de emergência recorrem ao saber construído com a experiência no trabalho. Silva e Muniz (2011), em análise sobre o cotidiano do setor de emergência de um hospital universitário, identificaram que a partir de suas experiências, os trabalhadores mesmo num ambiente de trabalho precário, buscavam diferentes estratégias defensivas para dar conta do sofrimento causado pelo seu labor diário. $\mathrm{O}$ sofrimento maior não estava relacionado ao lidar com a morte ou doença, mas à sua compreensão de não dispor dos meios necessários para cuidar dos pacientes. 
As circunstâncias nas quais acontece a relação entre as mulheres em atendimento e as trabalhadoras do setor de admissão condicionam perturbações no processo de trabalho e interferem na qualidade da assistência prestada. Este fato repercute em todo o curso do cuidado na maternidade, uma vez que a abordagem inicial na chegada à maternidade é fundamental para a construção do plano de atenção envolvendo a gestante, sua família e os próprios trabalhadores. Assim, para desenvolver suas atividades, enfermeiras e técnicas de enfermagem do setor de admissão lidam com diversas restrições, buscando cumprir ao seu modo a tarefa colocada pela organização.

\section{Restrições, sobrecarga e intensificação do trabalho das técnicas e enfermeiras do setor de admissão}

A ficha de atendimento é feita no setor da recepção da emergência onde trabalha um funcionário por plantão. A ele cabe fazer o primeiro contato com as mulheres que procuram o serviço. Quando há aumento da demanda, a recepção atrasa em levar a ficha ao setor de admissão, o que faz com que as técnicas de enfermagem se desloquem para pegá-las, introduzindo assim função não prevista. Para evitar muitos deslocamentos, as técnicas avaliam quando devem sair do setor de admissão e essa estratégia busca regular seu desgaste físico, de modo a garantir a continuidade dos atendimentos. Esses setores guardam relação de dependência entre si, e o ritmo de trabalho é determinado pela quantidade de fichas para atendimento.

A equipe de enfermagem do setor de admissão da emergência é composta por duas a três técnicas e uma enfermeira por plantão. O dimensionamento do número de profissionais escalados varia conforme o período de maior demanda por atendimento e é modulada pelo déficit de postos de trabalho. Durante o plantão diurno, são três técnicas e uma enfermeira, nesse há maior demanda, e à noite geralmente ficam duas técnicas de enfermagem sem a presença de enfermeira neste setor.

Nos plantões noturnos, a enfermeira escalada para as enfermarias permanece como suporte eventual ao setor de admissão. Delgado e Oliveira (2005) afirmam que o número insuficiente de trabalhadores pode contribuir para a insatisfação no trabalho pela sobrecarga de atividades, o que também pode acarretar queda na qualidade da assistência prestada e aumento de absenteísmo. 
$O$ déficit de enfermagem na maternidade, principalmente de enfermeiras, pode agravar o contexto de sobrecarga de trabalho, absenteísmo e afastamento por doenças ocupacionais. A atuação da enfermeira em múltiplos setores produz diversas exigências e tem gerado sobrecarga. Oliveira (2009), em estudo sobre o adoecimento dos trabalhadores da enfermagem no pronto socorro de um hospital universitário, descreve que as transformações tecnológicas, organizacionais, com políticas de flexibilização do trabalho, estão produzindo redução da margem de manobra desses profissionais frente ao sofrimento presente no contexto laboral. Isto se manifesta também, no presente estudo, no relato da Enfermeira B: "O enfermeiro na maternidade não fica muito no setor, tem uma abrangência e responsabilidade em mais de um setor, por exemplo, à noite ficam três a quatro enfermeiras e cada uma fica com dois setores no mínimo".

Sobre a forma de atuar nesses setores, ela relata ainda: "A gente prioriza $o$ que é mais importante, se a admissão está tranquila, eu dou mais presença na enfermaria, priorizando o setor que mais está exigente".

Esse contexto de trabalho tem contribuído para o afastamento da enfermeira do atendimento direto às mulheres, dificultando a participação desse profissional na dinâmica de atendimento no setor de admissão. $\mathrm{Na}$ maioria dos casos, a enfermeira acaba exercendo as atividades administrativas, cabendo às técnicas de enfermagem as atividades mais relacionadas ao cuidado. Melo (1983) diz que a organização do trabalho de enfermagem tem características do pensamento taylorista no reforço à separação entre concepção e execução, orientado por uma rígida estrutura hierárquica com excessiva divisão e controle sobre o trabalho. No trabalho da equipe de enfermagem no setor de admissão, existe uma nítida separação entre as funções gerenciais e de assistência. Contudo, nos momentos em que as enfermeiras foram solicitadas pelos técnicos de enfermagem, não se mostraram resistentes para executar ações assistenciais, que geralmente ocorrem nas situações de maior gravidade ou de iminência de parto no setor de admissão.

Para as enfermeiras, o trabalho voltado para a execução de atividades gerenciais restringe sua atuação no setor de admissão. Na sua compressão, caberia aos enfermeiros fazer o primeiro atendimento às mulheres e realizar a assistência ao parto natural e na ocorrência de eventuais problemas clínicos faria a solicitação de avaliação com o obstetra. A classificação de 
risco das mulheres deveria ser o principal foco da atuação das enfermeiras. No setor de admissão não há enfermeiras com formação especifica em obstetrícia, o que poderiam ampliar o escopo de resolutividade do atendimento na assistência ao trabalho de parto fisiológico.

O setor de admissão não funciona de acordo com o protocolo de classificação de risco em obstetrícia. A enfermeira, nos momentos de maior fluxo, vai até a recepção da emergência avaliar os sinais vitais das mulheres, antecipando o atendimento médico, quando confrontada sobre o porquê de estar fazendo isso, respondeu: "pode acontecer de alguma mulher evoluir para parto na recepção”. Essa estratégia traz o sentimento de mais segurança sobre a situação de saúde e também acalma os ânimos de quem esperava por atendimento na recepção.

Quando há enfermeira no plantão, as técnicas se ocupam menos em atividades como: buscar vagas nos setores, solicitar coleta de laboratório e nutrição, arrumar os prontuários e fazer o pedido de medicações à farmácia, o que facilita o desenvolvimento das suas tarefas ligadas à assistência. Durante as observações foi possível descrever as atividades realizadas no setor de admissão. Praticamente todas as tarefas são de assistência direta e desenvolvidas pelas técnicas de enfermagem. A enfermeira participa pouco do cuidado. $\mathrm{Na}$ sua ausência, as tarefas gerenciais também são absorvidas pelas técnicas de enfermagem e podem complicar ainda mais na assistência às mulheres.

O déficit de enfermeira no setor de admissão é histórico na maternidade e levou as obstetras a assumirem a posição de supervisão e direcionamento do trabalho das técnicas de enfermagem. O déficit aliado à sobrecarga de trabalho das enfermeiras que assumem mais de um setor durante os plantões tem produzido uma rotina estressante para essas trabalhadoras.

Segundo Gray-Toft e Anderson (1981), as enfermeiras costumam relatar mais estresse ocupacional do que os demais profissionais de enfermagem. Esse contexto também dificulta a atuação segundo o ofício profissional, conforme relato de uma Enfermeira B:

No setor de admissão a gente fica muito solto, mesmo porque a gente não recebe os pacientes, quem recebe são os técnicos de enfermagem. A gente é acionada quando tem intercorrências, a gente não vê quando a paciente está sendo examinada, não ouve quando a médica está conversando com a paciente, muitas vezes não consegue evoluir porque está em outra unidade e tem 40 prontuários de mãe e filho para abrir. 
O déficit de enfermeiras na maternidade e, em especial, neste setor, levou as técnicas a transporem os limites da sua competência legal - previstas externamente no âmbito da regulação profissional - na assistência, expondo-as também a risco de saúde. Nas situações em que havia conflito, as técnicas recorriam geralmente às enfermeiras de outros setores ou à própria diretoria de enfermagem. Leila Dotto, Marli Mamede e Fabiana Mamede (2008), ao estudarem as competências no atendimento às parturientes na admissão de duas maternidades, revelaram que os profissionais de nível médio atuam na admissão e no trabalho de parto além da sua qualificação profissional.

O ritmo ditado pelo trabalho no setor de admissão obriga as técnicas de enfermagem a tomar decisões e assumir sozinhas situações nas quais não possuem competência legal. Como exemplo, ter de decidir sobre a administração de medicações prescritas pelas obstetras, para serem administradas "se necessário”, para episódios de náuseas e dores; transferir mulheres internadas de um setor para o outro; assistir ao parto e atuar na assistência nos casos de risco de morte, sem a presença da enfermeira. Guedes, Lima e Assunção (2005) explicitam que a execução de tarefas não previstas na regulação profissional ao invés de representar uma indisciplina, significa a diferença entre antecipar ou não um dano à saúde do paciente, ou seja, nas condições reais de trabalho das técnicas de enfermagem, decidir sobre o ato de medicar, "se necessário", é habitual e apenas tem visibilidade quando se relaciona a algum problema. Neste momento, frequentemente, os determinantes do sistema de trabalho são omitidos e o ato pode ser visto como indisciplina profissional. Assim, estar responsável pelo ato de medicar nessas circunstâncias pode, na verdade, representar um forte estressor para a trabalhadora de enfermagem.

Os técnicos de enfermagem atuam sem protocolos escritos e seu trabalho acontece segundo suas experiências no setor. Esse fazer se estrutura de acordo com as demandas que vão surgindo nas situações e são orientadas pelo “saber-fazer” de cada técnico de enfermagem. No cotidiano, existe cooperação, principalmente com as menos experientes. Barros e Santos Filho (2011) indicam que, ao gerir seu trabalho, os humanos inventam formas de cooperação e certa relação de si em um incessante processo de criação.

Sobre a jornada de trabalho, as trabalhadoras cumprem jornada de 10 a 11 plantões mensais com flexibilidade nas trocas e realização de plantões adicionais por meio de negociação entre eles. Como modo de conciliar diferentes vínculos de emprego, as trabalhadoras frequentemente realizam 
trocas entre si ou “compras de plantão", buscando concentrar os plantões durantes as semanas. Fato que colabora para o aumento da sobrecarga e exaustão física e mental no trabalho. O processo de "compra de plantões" é regulado pela Diretoria de Enfermagem.

Durante os plantões observados, o atendimento também esteve condicionado à disponibilidade de macas no setor de admissão. A indisponibilidade de vagas nas enfermarias, ocupação das camas e mesas de parto no centro obstétrico, gera dificuldade nas transferências para outros setores conforme fluxo previsto pela unidade, o que paralisa o atendimento no setor de admissão da emergência. Em algumas situações, foi necessário colocar macas e cadeiras de roda no corredor para realizar os atendimentos. Esse contexto aponta a interdependência no funcionamento entre o trabalho executado nos diferentes setores da maternidade.

Para dar conta da demanda, as trabalhadoras precisaram criar suas estratégias para regular as exigências. Ao assumir o plantão, as enfermeiras e técnicas procuram conhecer a situação de quem está nas macas no setor de admissão e providenciar a transferência daquelas internadas é a primeira operação a ser feita, o que representa a redução de restrições no curso de atendimento previsto pela organização do trabalho. Esse processo consome parte importante da disposição e do tempo no início dos plantões, porque precisam sair do setor para tentar vagas nas enfermarias ou no centro obstétrico. Responder à falta de vagas impõe às enfermeiras e técnicas realizarem suas tarefas, porém não da forma que gostariam de desenvolvê-las. Para atingir os objetivos do trabalho em condições determinadas, o trabalhador reconstrói permanentemente seus modos operatórios. (GUÉRIN et al., 2001) Esse contexto foi trazido por uma técnica de Enfermagem, questionada sobre a primeira atividade que realiza ao chegar ao setor: "depende, geralmente eu organizo o setor para começar a trabalhar, não tem como vocêfazer isso depois, primeira coisa quando você chega é arrumar a unidade". Refere-se assim ao fato do setor de admissão encontrar-se habitualmente com leitos e macas ocupados por pacientes que ainda não conseguiram leitos para internamento, daí a necessidade de "arrumar a unidade".

Mulheres internadas e mantidas no setor de admissão pela ausência de leitos disponíveis, aguardando transferência, representam constrangimentos para as trabalhadoras do setor e significam realizar tarefas como: fazer a evolução clínica, realizar visitas periódicas ao leito, administrar medicações 
de horário, verificar os sinais vitais da mãe e da criança, acompanhar a dinâmica do trabalho de parto e intervir quando necessário. Isso representa mudança na cadência do trabalho, significa adicionar tarefas que divergem daquelas previstas para um setor de pronto-atendimento.

A superlotação dos leitos também interfere na continuidade da assistência entre os plantões, pois não há como resolver as demandas que vão aparecendo durante o plantão e, geralmente, diversos procedimentos são repassados para a equipe seguinte, o que tem gerado conflito entre as trabalhadoras. As pendências deixadas perturbam a organização do trabalho e, na maioria das vezes, representam eventos que já deveriam ser resolvidos ou providenciados no plantão. Esta sobrecarga adiciona ainda mais a pressão temporal ao trabalho de quem assume o plantão. Por isto, o início de cada plantão, apesar de ser mais tenso, é o primeiro momento de planejamento do trabalho frente à análise das situações encontradas.

A maioria das restrições colocadas no cotidiano do trabalho de técnicas e enfermeiras no setor de admissão da emergência, conforme observado nesta pesquisa, tem como principais aspectos: a) variabilidade e excesso da demanda de atendimentos no setor; b) déficit de trabalhadoras; c) intensificação do trabalho da enfermeira atuando em múltiplos setores durante o plantão; d) sobrecarga de trabalho e exposição dos técnicos de enfermagem que atuam sem a supervisão e apoio direto da enfermeira; e) falta de protocolos escritos sobre as tarefas da equipe de enfermagem; f) o ritmo de trabalho ditado pelos usuários, gerando sobrecarga e pressão temporal com consequências à saúde desses trabalhadores; g) sobreposição de atividades na relação entre obstetras e enfermeiras no que tange à supervisão dos técnicos de enfermagem.

\section{Variabilidade como contexto: a cooperação e experiência como caminhos para o trabalho no setor de admissão}

Cada equipe de plantão no setor tem seu modo particular de atuar frente às situações. Existe certa identificação entre as técnicas de enfermagem e enfermeiras, pois a maioria trabalha junto há muito tempo, dado que as escalas de trabalho são fixas, o que contribui para a criação de vínculos entre as trabalhadoras.

A dinâmica de cada plantão varia segundo fatores externos ao trabalhador, mas também é influenciada por características dos próprios sujeitos 
no trabalho. Em determinados plantões, o fato de uma das técnicas de enfermagem ter habilidade em atendimento pré-hospitalar, o que pressupõe tomada de decisões rápidas e capacidade de lidar com contextos adversos, dá agilidade aos processos de trabalho e consegue acelerar o fluxo de encaminhamento de mulheres para outros setores.

Como forma de organizar e facilitar o trabalho no setor de admissão, as técnicas de enfermagem dividem virtualmente as tarefas em dois fluxos distintos: nos boxes iniciais, o fluxo é de entrada de mulheres que aguardam atendimentos na recepção; o segundo envolve macas próximas da porta de saída para enfermarias e centro obstétrico, para onde são direcionadas as mulheres internadas que aguardam por vaga.

A demanda existente e a disponibilidade de vagas modulam a distribuição e a ocupação das macas da admissão. As diferentes formas de organizar o trabalho nas situações reais são importantes frente à permanente superlotação. Para Abrahão (2000), a variabilidade presente nas situações de trabalho implica repensar a estruturação das atividades. Os trabalhadores atuam como sujeitos no árduo processo de busca do equilíbrio entre suas capacidades e os seus limites. Não há prescrição que dê conta da complexidade do trabalho nas condições reais, essa acaba se atualizando em ato.

O remanejamento ou transferência de pacientes exige a negociação entre os trabalhadores de diferentes setores. Na prática, esse processo é permeado por conflitos e depende da relação pessoal entre as equipes. Mesmo compartilhando do contexto de superlotação dos leitos, fato objetivo e incontestável, os vínculos afetivos entre os trabalhadores influenciam as negociações e os acordos para viabilizar os remanejamentos. Ao trabalhador cabe, portanto, usar o melhor de si, em um esforço invariavelmente invisível e sem reconhecimento, para superar os limites do sistema de trabalho e assegurar a qualidade do seu serviço de cuidado ao paciente. Com este compromisso e nas condições objetivas de trabalho, há barganha, negociação, pedido de leito para a paciente. Ou seja, para quem trabalha no setor de admissão, esse recurso representa transpor as contradições do trabalho real para seguir com as tarefas previstas para o setor de admissão.

O crescente número de mulheres aguardando atendimento na recepção acelera o ritmo das atividades na admissão e em todos os demais setores da maternidade, mesmo sem a presença direta das imposições gerenciais. Situação semelhante se observa em diversos setores do comércio em que a 
demanda de clientes exerce papel regulador e acelerador do ritmo do trabalho, como nos operadores de caixas de supermercado, bancos etc. (PENA; MINAYO-GOMEZ, 2010)

Foram constantes os deslocamentos dos trabalhadores do setor de admissão para obter vagas nas enfermarias ou no centro obstétrico, colaborando para o aumento do esforço físico, desgaste e fadiga no trabalho.

Você viu hoje os remanejamentos, manda daqui para lá, de lá volta para aqui e assim daqui vai para enfermaria, é isso. [...] Ultimamente tem acontecido muito. Sexta-feira eu trabalhei nesse mesmo rodízio, essa mesma coisa e os dias mais críticos são segunda, terça, amanhã, quinta. (Técnica A)

Os remanejamentos internos não estão previstos pela organização do trabalho, porém são estratégias criadas para regular a superlotação e garantir o funcionamento do setor de admissão. Para realizá-los, as técnicas e enfermeiras negociam e estabelecem comunicação com outros setores buscando conhecer a situação e tentando antecipar o surgimento das vagas. As restrições da superlotação autorizam o trabalhador a decidir sobre o momento de remanejar, sem a necessidade de comunicar à equipe dirigente. Essa operação se destina a resolver a questão da falta de vagas, no entanto, apesar da preocupação dos trabalhadores, a estratégia expõe mulheres e crianças a riscos de saúde, conforme comenta a Técnica A: “aqui não é lugar para essa puérpera ${ }^{1}$, ela deveria estar numa cama com o bebê e a família dela, acompanhante não pode ficar aqui”.

Em outros casos, a falta de vagas na maternidade, não apenas no setor de admissão, gerou tensão no trabalho. Frequentemente o Serviço de Atendimento Médico de Urgência (SAMU) solicita atendimento para mulheres ou bebês oriundos da residência ou abordados em via pública com algum problema de saúde. Apesar da lotação completa com a demanda da porta de entrada, os trabalhadores não podem recusar esses atendimentos. Em alguns casos, houve a possibilidade de recusa pelo insucesso nas estratégias utilizadas para conseguir vagas para esse tipo de atendimento. Porém, nas situações observadas, esse tipo de demanda foi solucionado mesmo significando o uso da maca como leito ou priorizando o atendimento no centro obstétrico, o que resulta no aumento do tempo de espe- 
ra de atendimento de quem aguarda na recepção. Almeida e Pires (2007) apontam que os trabalhadores de emergência podem se sentir impotentes e desgastados diante da demanda de trabalho superior às capacidades de resposta da equipe.

Existem ainda dificuldades relacionadas à transferência de casos graves, quando a maternidade não dispõe de tecnologia para resolver, nesses casos as obstetras do setor de admissão se deslocam para realizar o atendimento geralmente no centro obstétrico. A Central Estadual de Regulação (CER) é acionada para viabilizar a transferência para maternidades de maior complexidade, mas isso demora a ser realizado. Com a ausência das obstetras no atendimento da admissão, as técnicas de enfermagem ficam sozinhas no atendimento. Como consequência adicional, essa situação resulta no bloqueio dos leitos e aumento nas exigências e na tensão na assistência. A interação de fatores externos e internos ao trabalho no setor de admissão contribui para a atualização permanente dos compromissos e singulariza diferentes modos de desenvolver a atividade. (GUÉRIN et al., 2001)

Esse setor é o único da maternidade que não permite a presença de acompanhante durante a permanência da mulher. A falta de privacidade nos boxes de atendimento e a circulação excessiva de pessoas se colocam em contradição com a garantia do direito das mulheres a acompanhante. No Brasil, em estudo recente com mulheres acompanhadas no processo de parto, demonstrou-se índice de satisfação cinco vezes maior em relação à assistência prestada antes, durante e após o parto quando comparadas às não acompanhadas. (BRÜGGEMANN, 2005) Para lidar com essa contradição, algumas técnicas de enfermagem negociam a entrada com os acompanhantes, a exemplo: "Quando vejo uma situação dessa eu seguro: espere um pouquinho lá fora, na hora que a gente resolver, se ela internar, não se preocupe que venho the chamar aqui e você vai entrar com sua mulher". (Técnica A)

Há pouca interlocução com o serviço das assistentes sociais do setor de admissão, cabendo aos trabalhadores de enfermagem a mediação nesses casos. Em alguns momentos houve resistência das próprias trabalhadoras sobre a presença de acompanhante, por receio na cobrança pela demora no atendimento. Nas situações de trabalho, os trabalhadores mobilizam o "saber-fazer", que corresponde às práticas, às técnicas e também aos conhecimentos científicos, adquiridos pela experiência no trabalho, o "saber-ser", 
que envolve o comportamento, o caráter e a personalidade nas relações sociais de trabalho e o "saber-agir", que advém das decisões frente às exigências do trabalho. (LIMA, 2001)

A construção de vínculo entre técnicas de enfermagem e enfermeiras da admissão, e entre as equipes da enfermaria e centro obstétrico foi percebida como fundamental para superar as situações de restrição no atendimento e diminuição da sobrecarga de trabalho.

O sofrimento provocado pela organização do trabalho quase sempre não é reconhecido. (DEJOURS, 2005) Há negociação durante os remanejamentos, porém acontecem em cenários de conflitos entre os trabalhadores de diferentes setores. Esse processo não está previsto pela organização do trabalho. Mesmo utilizando estratégias na busca de solucionar os conflitos e tensões que estão fora do previsto para a execução do seu trabalho, as técnicas e enfermeiras estão expostas aos estressores.

\section{A experiência na atividade de trabalho das enfermeiras e técnicas de enfermagem}

No curso da observação foi possível perceber a habilidade das trabalhadoras em contornar situações difíceis, como a demora no atendimento e presença de acompanhantes do sexo masculino, aspectos trazidos por elas como potenciais fontes de insegurança para o trabalho.

$\mathrm{O}$ fato de serem mulheres as tornam mais vulneráveis às agressões. Em estudos com técnicos de enfermagem, identificou-se experiências psicológicas negativas expressas pelo sentimento de culpa desses profissionais diante de episódios de agressividade dos pacientes. No cenário de excesso de tarefas, com meios insuficientes, não é esperado outro resultado além de conflitos e desgaste na relação entre trabalhadores e usuárias.

Os efeitos psicológicos negativos são gerados pelo contato direto com a dor, sofrimento das pessoas e por níveis excessivos de responsabilidades e são agravados nas situações em que o tempo de planejar e preparar o trabalho é insuficiente, com interrupções constantes e poder de decisão restrito. A demora no atendimento aumenta a zona de incertezas sobre a situação de saúde para quem aguarda. Dejours (2005) diz que o sofrimento aparece quando fracassam as estratégias do trabalhador para cumprir com sua tarefa. Salomé, Martins e Espósito (2009) concluiram, em seu estudo com 
profissionais de enfermagem de uma unidade de emergência, que apesar do estresse que esses profissionais enfrentam durante o cotidiano de trabalho, eles mantêm o compromisso de prestar uma assistência de qualidade e humanização, havendo também tendência à exaustão emocional, desânimo e sentimentos de angústia.

O trabalho da enfermagem se baseia no acompanhamento contínuo da situação de saúde daquele que está sendo assistido. Deste modo, o registro de informações orienta novas condutas e ajusta a sistematização da assistência prestada. No setor de admissão, em detrimento do ritmo de trabalho o registro sobre parâmetros clínicos e procedimentos realizados pelas técnicas de enfermagem é feito num rascunho e posteriormente ocorre a transcrição nos prontuários. Além disso, as anotações são pouco detalhadas e não expressam a situação de saúde das mulheres. Existe uma dificuldade de realizar pausas entre os procedimentos nas diferentes mulheres em atendimento no setor, o que pode acarretar erro de registro nas informações.

Após a avaliação obstétrica na admissão, é solicitado às técnicas de enfermagem que realizem as seguintes tarefas: entrega do avental da maternidade, administração das medicações e providências quanto à realização dos exames de coleta se sangue. Pelo excesso de demandas, antes da avaliação médica, os técnicos de enfermagem adiantam a aferição da temperatura $\mathrm{e}$ da pressão arterial, como forma de ganhar tempo para os demais procedimentos. Realizam em conjunto a punção venosa e a administração das medicações prescritas com o objetivo de encurtar o tempo das atividades. Guedes, Lima e Assunção (2005), analisando auxiliares de enfermagem, explicitaram que esses trabalhadores conseguem responder às perturbações por meio da antecipação de ações que visam a qualidade da assistência.

Em seguida, a enfermeira ou as técnicas de enfermagem solicitam ao laboratório para realizar as coletas de sangue, essa solicitação é feita por telefone com algumas dificuldades, às vezes, o ramal fica ocupado e em outros casos há demora em responder ao chamado. Quando existe o contato com o técnico de laboratório, esse normalmente demora em realizar a coleta de sangue, o que aumenta o tempo para definição sobre a conduta obstétrica. Essas dificuldades aumentam a pressão sobre o tempo de execução das tarefas colocadas para os técnicos de enfermagem.

Apesar dos horários estabelecidos para as refeições, geralmente, a equipe de enfermagem, principalmente as técnicas, tem dificuldade em 
usufruir dos intervalos. Por vezes, abdicam desse direito para não deixar acumular os procedimentos. Esses momentos têm sido cada vez mais restritos e atravessados pelo aumento da demanda. Nestes casos, apesar de haver divisão do trabalho para não prejudicar o atendimento, as regulações não têm sido suficientes para dar conta do volume da demanda. A intensidade do trabalho interfere nos horários destinados às refeições, segundo a Técnica B: "vamos pra refeição que nossa sobremesa é parto ou sangramento, é isso! A gente nem senta, sai de lá e dá continuidade, quando dá senta, quando não dá vai direto".

Outras tarefas sempre foram desenvolvidas pelas técnicas de enfermagem, como exemplo, o transporte em macas das mulheres internadas entre os setores. A movimentação e o transporte de pacientes, a postura corporal inadequada, o déficit de trabalhadores, os equipamentos inadequados e sem manutenção foram os riscos ocupacionais mais enumerados pelos trabalhadores. Foi observado que as macas dos boxes dificultam o transporte, são fixas e não dispõem de rodas, sendo necessário trazer outra maca para transportar as mulheres. Geralmente, opta-se por realizar as transferências com cadeiras de rodas. A mobilização e os deslocamentos constantes são exigências físicas que podem estar associados a problemas musculoesqueléticos. (FONSECA; FERNANDES, 2010)

A experiência dessas trabalhadoras confere mais segurança e tranquilidade nas situações nas quais se sabe o que deve ser feito. No estudo em tela, a maioria trabalha no setor de admissão há mais de 10 anos, alguns estão desde a inauguração da maternidade, como se refere uma das trabalhadoras: "Quando eu cheguei aqui ainda ia ser inaugurada, só que não tinha nada, só muita poeira, não tinha móveis, não tinha material para a gente trabalhar”.

Para lidar com a intensificação do trabalho, essas profissionais trocam experiência e se comunicam constantemente durante o plantão, porém, com o aumento do fluxo de atendimento diminui o tempo de conversas. A Diretoria de Enfermagem constrói as escalas de trabalho com base na experiência, colocando juntas trabalhadoras com diferentes experiências na assistência ao parto. Nessas situações, as trabalhadoras mobilizam saberes, resolvem ou não buscar informações que não estão imediatamente disponíveis, estabelecem relações entre os diferentes elementos da situação e antecipam as consequências de suas ações. (GUÉRIN et al., 2001) Em relação à experiência para o trabalho no setor de admissão, a diretora de enfermagem salienta que: 
"As novas têm disposição, mas com as antigas na emergência a resolutividade é muito grande. Se chegar alguém parindo em período expulsivo, eu tenho certeza que elas não vão correr [...] as mais antigas são as que seguram".

No processo de coordenação das equipes da admissão não há reuniões ou encontros sistemáticos entre as trabalhadoras e suas coordenações, o que dificulta a análise coletiva dos contextos de trabalho, negociação das tarefas e a decisão partilhada sobre a organização do trabalho. Não são previstos na organização do trabalho espaços coletivos para discussão sobre questões ligadas ao "fazer" do trabalhador, com trocas de experiências. Barros e Santos Filho (2011) comenta que é preciso demarcar a importância de se ver os trabalhadores em uma exigência permanente de cooperação, de trocas e aprendizagens para o enfrentamento de situações-desafios, fazendo escolhas, assumindo riscos, gerindo seu próprio trabalho e adquirindo competências durante o processo.

A gerência da maternidade tem realizado processos de formação para os trabalhadores do setor de admissão, porém não existem atividades sistemáticas de treinamento para o desenvolvimento de competências específicas. Apesar disto, o setor de admissão é visto por algumas técnicas de enfermagem como lugar em que se aprende muito, como se refere a Técnica B:

Tem coisa que a gente nunca viu e vê aqui, têm procedimentos que a gente acha normal, outros que você nunca viu, a gente vai aprendendo, a cada dia surgem coisas novas, aparelhos de primeiro mundo, isso facilita pra gente.

Compartilhar as dificuldades e as estratégias utilizadas nas situações de trabalho do setor de admissão da emergência pode ampliar as margens de manobra dos trabalhadores, ampliando suas competências e reposicionando a organização do trabalho de modo a favorecer a sua realização pessoal e profissional. Dal Pai e Lautert (2008), em estudo sobre o trabalho em urgência e emergência relacionado à saúde das profissionais de enfermagem, identificou que mesmo numa dinâmica de trabalho por vezes danosa, o benefício do trabalho desses profissionais está no valor simbólico da atuação, no atributo moral da atividade de salvar vidas.

Algo que chamou a atenção durante as observações foi a presença da equipe dirigente no setor de admissão, se colocando junto às trabalhadoras, trocando informações sobre como dar solução a situações colocadas e, em vários momentos, assumindo tarefas que dependiam de articulações com outros se- 
tores da maternidade. Em todos os momentos no setor de admissão há intensa comunicação entre as trabalhadoras e a equipe dirigente, seja presencialmente ou por telefone. $\mathrm{O}$ suporte social, em permitir o compartilhamento do trabalho com colegas, pode ter efeito redutor sobre as demandas físicas e psicológicas.

Na maioria dos casos observados, as técnicas de enfermagem demonstraram cumplicidade e solidariedade quando da ausência de uma colega do plantão seguinte. Nessas situações, a trabalhadora permaneceu no setor por mais 12 horas ou outra técnica de folga foi acionada. Existe a preocupação com o aumento da sobrecarga de trabalho para a técnica de enfermagem que vem a assumir sozinha o plantão, o que também representa implicação desses trabalhadores com o funcionamento do serviço, conforme declara a Técnica B: “Assim conciliamos as coisas, quando tem um colega que tá doente que não pode vir, a gente cobre o plantão para não ficar descoberto, a gente está em casa de folga, eu mesmo fiz isso muitas vezes".

Em outra situação, as técnicas de enfermagem do setor deram apoio nas atividades de outra trabalhadora que estava gestante, assumindo inclusive alguns plantões na sua impossibilidade de ir à maternidade. Entretanto, a solidariedade desvela a insuficiência de profissionais e, ao mesmo tempo, em outros casos a ausência de notificação de doenças relacionadas ou não ao trabalho que acometem àqueles que faltaram ao trabalho.

As condições de trabalho da enfermagem observadas no setor de admissão indicam multiplicidade de atividade com ritmo de trabalho intenso, desgaste físico e mental na execução das atividades. A experiência e a implicação das trabalhadoras de enfermagem ajudam a regular as restrições do trabalho real, na tentativa de viabilizar os objetivos da maternidade.

\section{Considerações finais}

Trabalhar em serviços de emergência requer lidar com imprevistos, ter a capacidade de agir na urgência e decidir na incerteza, além de possibilitar momentos de autonomia e criação diante da imprevisibilidade. No seu cotidiano, a superlotação dos leitos tem sido o principal cenário encontrado pelos trabalhadores e usuários. Essa característica se relaciona com a ocupação dos leitos, ocorrência de pacientes em macas, aumento do tempo de espera para o atendimento e pressão para a equipe realizar atendimentos. Quando esse trabalho significa atuar no cuidado ao nascimento, esse cená- 
rio adquire complexidade ainda maior. Mesmo sendo a gravidez definida como um evento de urgência ou emergência, não significa necessariamente risco à vida.

A caracterização da atividade de trabalho das técnicas e enfermeiras do setor de admissão da emergência através da AET permitiu identificar as dificuldades e restrições relacionadas ao excesso da demanda de atendimentos, gerando sobrecarga de trabalho, ritmo de trabalho ditado pelos usuários e pressão temporal. $\mathrm{O}$ trabalho intenso com desgaste físico e mental na execução das atividades está presente no contexto de trabalho da enfermagem no setor de admissão.

Apesar das estratégias adotadas pelas trabalhadoras para viabilizar a assistência às mulheres, evidenciou-se a absoluta incapacidade da maternidade em responder às demandas de atendimento. Assim, impõe-se a revisão da capacidade instalada de serviços pela rede pública a fim de viabilizar o acesso das parturientes a outras unidades/maternidades, compatibilizando demanda com capacidade de atendimento.

A insuficiência dos meios de trabalho, o déficit de técnicas e enfermeiras no setor, a estrutura física não adequada para assistir a população e a baixa capacidade de leitos frente à demanda atendida conformam uma situação que aprofunda a exposição a doenças, acidentes e violências ocupacionais.

A sobrecarga de trabalho da enfermeira está relacionada à sua atuação em múltiplos setores com diversas exigências, o que dificulta sua participação na dinâmica de atendimento no setor de admissão, fragmentando o trabalho da enfermagem enquanto equipe. Para as técnicas de enfermagem, a sobrecarga é relativa ao excesso de procedimentos e de tarefas, além do previsto para sua função. Para atender aos objetivos da organização, técnicas e enfermeiras da admissão da emergência criam diferentes estratégias frente a situações restritivas como forma de garantir o andamento do serviço. A experiência e o compromisso das trabalhadoras de enfermagem ajudam a viabilizar os objetivos da maternidade, porém à custa de mais exposição aos riscos à saúde.

A forma como é organizado o processo produtivo no setor de emergência representa risco potencial à saúde e à segurança dos trabalhadores e às medidas implementadas não têm sido suficientes. $\mathrm{O}$ envolvimento de dirigentes, trabalhadores e usuários em reuniões permanentes, mediadas pelo compartilhamento e problematização das situações de trabalho, pode 
contribuir com adoção de estratégias de melhoria dos ambientes de trabalho com reconhecimento e valorização dos trabalhadores como sujeitos das práticas em constante replanejamento do seu próprio trabalho. É importante na organização do trabalho considerar a experiência já existente dos profissionais e construir coletivamente as alternativas para a realização das tarefas a partir das condições reais, buscando também a preservação de sua condição de saúde.

O presente estudo apontou que para melhoria da saúde das trabalhadoras da admissão é fundamental haver o dimensionamento da força de trabalho de enfermagem de acordo com a demanda de atendimento real do setor. A alta demanda de pacientes e a insuficiência dos meios para executar o trabalho tornam difícil a promoção do ambiente de trabalho saudável. É necessário adotar medidas para adequar o trabalho, assegurando a ampliação da ação comunicativa e colaborativa no cotidiano do trabalho das trabalhadoras de enfermagem. Ampliar o poder de agir das trabalhadoras ajuda a superar as situações restritivas presentes no cotidiano laboral. A melhora da qualidade de vida e trabalho das trabalhadoras de enfermagem é essencial para humanização do atendimento nos serviços de saúde.

\section{Referências}

ABRAHÃO, J. I. Restruturação produtiva e variabilidade do trabalho: uma abordagem da ergonomia. Psicologia: Teoria e Pesquisa, Brasília, DF, v. 16, n. 1, p. 49-54, jan./abr. 2000.

ABRAHÃO, J. I.; PINHO, D. L. M. As transformações do trabalho e desafios teórico-metodológicos da ergonomia. Estudos de Psicologia, Campinas, v. 7, p. 4552, 2002. Número especial.

ALEXANDRE, N. M. C. Aspectos ergonômicos e posturais e o trabalhador da área de saúde. Semina: Ciências Biológicas e da Saúde, Londrina, v. 28, n. 2, p. 109118, jul./dez. 2007.

ALMEIDA, P. J. S.; PIRES, D. E. P. O trabalho em emergências: entre o prazer e o sofrimento. Revista Eletrônica de Enfermagem, Goiânia, v. 9, n. 3, p. 617-629. 2007.

ASSUNÇÃO, A. A. O saber prático construído pela experiência compensa as deficiências provocadas pelas condições inadequadas de trabalho. Trabalho \& Educação, Belo Horizonte, v. 12, n. 1, p. 35-49, 2003. 
BALISTA, R. R.; SANTIAGO, S. M.; CORRÊA FILHO, H. R. A descentralização da vigilância da saúde do trabalhador no município de Campinas, São Paulo, Brasil: uma avaliação do processo. Cadernos de Saúde Pública, Rio de Janeiro, v. 27, n. 4, p. 759-768, abr. 2011.

BALSAMO A. C.; FELLI, V.E. A. Estudo sobre os acidentes de trabalho com exposição aos líquidos corporais humanos em trabalhadores da saúde de um hospital universitário. Revista Latino-Americana de Enfermagem, Ribeirão Preto, v. 14, n.3, p. 346-353, maio/jun. 2006.

BARBOZA, D. B.; SOLER, Z. A. S. G. Afastamentos do trabalho na enfermagem: ocorrências com trabalhadores de um hospital de ensino. Revista LatinoAmericana de Enfermagem, Ribeirão Preto, v. 11, n. 2, p. 177-183, mar./abr. 2003.

BARROS, M. E. B.; SANTOS FILHO, S. B. O trabalho em saúde nos referenciais da política nacional de humanização: construindo uma metodologia de análise e intervenção. In: GOMEZ, C. M.; MACHADO, J. M. H.; PENA, P. G. L. (Org.). Saúde do trabalhador na sociedade brasileira contemporânea. Rio de Janeiro: Fiocruz, 2011. p. 123-141.

BRITO, J. A. A ergologia como perspectiva de análise: a saúde do trabalhador e o trabalho em saúde. In: GomeZ, C. M; Machado, J. M. H.; Pena, P. G. L. (Org.). Saúde do trabalhador na sociedade brasileira contemporânea. Rio de Janeiro: FIOCRUZ, 2011. p. 479-494.

BRÜGGEMANN, O. M. O apoio à mulher no nascimento por acompanhante de sua escolha: abordagem quantitativa e qualitativa. 2005. $18 \mathrm{o}$. Tese (Doutorado em Tocoginecologia) - Faculdade de Ciências Médicas, Universidade Estadual de Campinas, Campinas, 2005.

CANINI, S. R. M. S. et al. Acidentes perfurocortantes entre trabalhadores de enfermagem de um hospital universitário do interior paulista. Revista LatinoAmericana de Enfermagem, Ribeirão Preto, v. 10, n. 2, p. 172-178, mar./abr. 2002. CONTRERA-MORENO, L.; MONTEIRO, M. S.; ESPOSITO, S. L. Estudo dos acidentes de trabalho ocorrido entre trabalhadores de instituições que desenvolvem ações de saúde no município de São Carlos no ano de 2000 e registrados junto a Previdência Social. In: ENCONTRO DE PESQUISA EM ENFERMAGEM, 2., 2002, Águas de Lindóia. Anais... São Paulo: Escola de Enfermagem da Universidade de São Paulo, 2002.

DANIELLOU, F. Introdução: questões epistemológicas acerca da ergonomia. In: DANIELLOU, F. (Coord.). A ergonomia em busca de seus princípios: debates epistemológicos. São Paulo: Edgard Blücher, 2004· p. 1-18. 
DAL PAI, D.; LAUTERT, L. O trabalho em urgência e emergência e a relação com a saúde das profissionais de enfermagem. Revista Latino-Americana de Enfermagem, Ribeirão Preto, v. 16, n.3, p. 439-444, maio/jun. 2008.

DELGADO, L. M.; OLIVEIRA, B. R. G. Perfil epidemiológico do adoecimento dos profissionais de enfermagem de um hospital universitário. Nursing, São Paulo, v. 8, n.87, p.365-370, ago. 2005.

DEJOURS, C. A loucura do trabalho: estudo de psicopatologia do trabalho. 5. ed. São Paulo: Cortez: Oboré, 2005.

DOTTO, L. M. G.; MAMEDE, M. V.; MAMEDE, F. V. Desempenho das competências obstétricas na admissão e evolução do trabalho de parto: atuação do profissional de saúde. Escola Anna Nery, Rio de Janeiro, v. 12, n. 4, p. 717-725, dez. 2008.

FONSECA, N. R.; FERNANDES, R. C. P. Factors related to musculoskeletal disorders in nursing workers. Revista Latino-Americana de Enfermagem, Ribeirão Preto, v. 18, n. 6, p.1076-1083, nov./dez. 2010.

FUNDAÇÃO PERSEU ABRAMO; SESC. Mulheres brasileiras e gênero nos espaços público e privado. 2010. 301 slides, color. Disponível em: <http://csbh.fpabramo.org. $\mathrm{br} /$ sites/default/files/pesquisaintegra.pdf $>$. Acesso em: 20 maio 2013.

GUEDES, R. M. A.; LIMA, F. P. A.; ASSUNÇÃO, A. A. O programa de qualidade no setor hospitalar e as atividades reais da enfermagem: o caso da medicação. Ciência \& Saúde Coletiva, Rio de Janeiro, v.10, n. 4, p.1063-1074, out./dez. 2005. GUÉRIN, F. et al. Compreender o trabalho para transformá-lo: a prática da ergonomia. São Paulo: Edgard Blücher, 2001.

GRAY-TOFT, P.; ANDERSON, J. G. Stress among hospital nursing staff: its causes and effects. Social Science \& Medicine, v. 15A, p. 639-647, 1981.

LAVILLE, A. Ergonomia. Tradução de Márcia M. N.Teixeira. 2. ed. São Paulo: EPU, 1977 .

LIMA, F. P. A. A formação em ergonomia: reflexões sobre algumas experiências de ensino da metodologia de análise ergonômica do trabalho. In: KIEFER, C.; FAGÁ, I.; SAMPAIO, M. R. Trabalho - Educação - Saúde: um mosaico em múltiplos tons. Brasília, DF: MTE: FUNDACENTRO, 2001. p. 133-148.

MACHADO, M. H.MACHADO, M. H.; VIEIRA, A. L. S.; OLIVEIRA, E. Construindo o perfil da enfermagem. Enfermagem em Foco, Brasília, DF, v. 3, n. 3, p. 119-122, 2012. 
MELO, C. M. M. A divisão social do trabalho na enfermagem: contribuição ao estudo. 1983. 94 f. Dissertação (Mestrado em Saúde Comunitária) - Universidade Federal da Bahia, Salvador, 1983 .

OLIVEIRA, N. T. O processo de adoecimento do trabalhador da saúde: o setor de enfermagem do pronto socorro de um hospital universitário. 2009.148 f. Tese (Doutorado em Serviço Social) - Faculdade de Serviço Social, Pontifícia Universidade Católica do Rio Grande do Sul, Porto Alegre, 2009.

PENA, P. G. L.; MINAYO-GOMEZ, C. Premissas para a compreensão da saúde dos trabalhadores no setor serviço. Saúde e Sociedade, São Paulo, v. 19, n. 2, p.371383,2010 .

SALOMÉ, G. M.; MARTINS, M. F. M. S.; ESPÓSITO, V. H. C. Sentimentos vivenciados pelos profissionais de enfermagem que atuam em unidade de emergência. Revista Brasileira de Enfermagem, Brasília, DF, vol. 62, n. 6, p. 856-862, nov./dez. 2009 .

SILVA, N. M.; MUNIZ, H. P. Vivências de trabalhadores em contexto de precarização: um estudo de caso em serviço de emergência de hospital universitário. Estudos e Pesquisas em Psicologia, Rio de Janeiro, v. 11, n. 3, p. 821-840, 2011.

SCHWARTZ, Y. Trabalho e Ergologia. In: SCHWARTZ, Y.; DURRIVE, L. (Org.). Trabalho \& Ergologia: conversas sobre a atividade humana. 2. ed. Niterói: UFF, 2010.

WEISS S. J. et al. Estimating the degree of emergency department overcrowding in academic medical center: results of the National ED Overcrowding Study (NEDOCS). Academic Emergency Medicine, Illinois, v. 11, n. 1, p. 38-5o, Jan. 2004.

YASSI, A. Assault and abuse of health care workers in a large teaching hospital. Canadian Medical Association Journal, Ottawa, v. 151, n. 9, p. 1273-1279, Nov. 1994. 


\section{Reflexões sobre escolhas alimentares de nutricionistas com obesidade}

KÊNYA LIMA ARAÚJO

PAULO GILVANE LOPES PENA

MARIA DO CARMO SOARES DE FREITAS

\section{Introdução}

De acordo com a Organização Munidal de Saúde (OMS) quase 2 bilhões de adultos em todo o mundo estão com excesso de peso, e destes $11 \%$ dos homens e $15 \%$ das mulheres são obesos. (WHO, [201-]) A "globosidade" tem sido um desafio para a saúde em todo o mundo - o que põe em relevo a exigência de pensar sobre ela.

O Ministério da Saúde do Brasil através da pesquisa "Vigilância de Fatores de Risco e Proteção para Doenças Crônicas por Inquérito Telefônico" (VIGITEL) evidenciou que mais da metade da população adulta do país (52,3\%) está com excesso de peso. (BRASIL, 2017) O cenário epidemiológico apresenta a gravidade deste estado de morbidade e a necessidade de discutir esse fenômeno que tem se mostrado difícil de ser superado.

Alguns elementos como comportamentos individuais, condições de vida e trabalho, e aspectos sociais relacionados à economia, educação e cultura podem ajudar a compreender o estado de saúde dos sujeitos. (CNDSS, 
2006) Nesse sentido, importa pensar o ambiente como modulador da saúde das pessoas, tanto no campo biológico, através de influência na expressão epigenética, quanto no tocante aos hábitos de vida - alimentação cotidiana e prática de atividade física regular, p.e., refletindo o peso corporal como resposta da condição de saúde. (BADZIAK; MOURA, 2010)

Aspectos que tocam a condição de vida e saúde dos sujeitos foram indicados como potenciais fatores obesogênicos em uma sociedade. O termo "obesogênico" foi inaugurado a partir de hipóteses sugeridas por Bruce Blumberg, pesquisador da Universidade da Califórnia, nos estudos relacionados a perturbadores endócrinos ambientais.

Nesse entendimento, vale considerar as reflexões de Bourdieu (1989) sobre habitus, que, para ele, revela um modo de ver e sentir o mundo. E nesta perspectiva, o cotidiano dos sujeitos, sua experiência social, referências do comer tendem a refletir as escolhas alimentares com base na cultura a qual pertence. Há um modo de comer que é aprendido, que marca sua vivência na sociedade, que sedimenta seu gosto e institui suas preferências.

A cultura se inscreve no processo alimentar dos humanos, com escolhas influenciadas pela forma como as pessoas veem e sentem o mundo. Escolhe-se o alimento e a quantidade. Comer moderadamente ou excessivamente. Também, quando se escolhe o que comer nem sempre se prioriza o consumo de nutrientes, mas a dimensão simbólica do alimento. O que este representa para si. Então, mudar hábitos alimentares significa mudar símbolos, representações. (CONTRERAS, 2011)

A mudança de comportamento alimentar é difícil. Pressupõe mudanças sociais e, no contexto do hábito, transformações nas relações estabelecidas entre tempo, alimentação e gosto. Nesse debate, ao recorrer à socioantropologia da alimentação, poderia afirmar que em cada sociedade há práticas alimentares com regras e significados que produzem sentidos de pertencimento e identidade. (CONTRERAS, 2011) Por esta razão, não é possível desprezar estes aspectos socioculturais para não ocorrer uma quebra no entendimento das diversas dimensões do ato de se alimentar. (FREITAS; MINAYO; FONTES, 2011)

$\mathrm{Na}$ área da saúde, o pensamento cartesiano limita a chance de compreensão sobre a associação entre dietética e sociedade. Como uma ruptura, a visão mecanicista reduz as ações desses profissionais de saúde. (MOTTA, D.; MOTTA, C.; CAMPOS, 2012) Em geral, a dietética torna-se prescrita 
e deficiente na correspondência com a cultura do paciente. No plano real, fora de conjecturas dualistas e fechadas, observa-se que a nutricionista portadora de obesidade vive esse conflito na "pele”: a contradição entre teoria e prática do cuidado de si.

Para o campo da saúde, a expressão “alimentação saudável” indica uma diretriz para a prevenção de doenças e também tende à associação com uma imagem corporal delgada para aqueles que a ela façam adesão. (SILVA, 2012) Ademais, para as nutricionistas desse olhar, serão, sobretudo, as normas técnicas que regem a alimentação saudável. Normas que se traduzem em cotas ideais de nutrientes, como uma ração essencial para a vida e a saúde.

A Resolução 380/2005 do Conselho Federal de Nutricionistas (CFN) trata das atribuições desse profissional na perspectiva da promoção de práticas alimentares saudáveis, ao tempo em que a Política Nacional de Alimentação e Nutrição (PNAN) propõe a adoção de estratégias para a prevenção da obesidade e outras doenças crônicas não transmissíveis - diabetes, hipertensão, outras cardiovasculares. (BRASIL, 2012; CFN, 2006)

As políticas públicas e programas governamentais no país (BRASIL, 2006, 2009, 2010, 2012) referenciam os profissionais especializados - nutricionistas, educadores físicos, médicos, psicólogos - para o cuidado de pessoas com excesso de peso.

A formação profissional do nutricionista impõe a racionalidade científica como possibilidade de aplicação técnica determinante para o controle e tratamento da obesidade. (LUZ, 2004) Normas dietéticas relacionadas a adequações do balanço energético são estratégias prioritárias na terapêutica indicada aos sujeitos com obesidade. $\mathrm{O}$ alimento é dissecado em nutrientes e valor calórico para definição de prescrições dietéticas. A dimensão simbólica do alimento é desconstruída nesta racionalidade.

A doença, enquanto desordem metabólica, requer intervenção especializada. Mas nessa concepção biomédica, o profissional de saúde em geral desconsidera o sujeito e seus valores sociais. Para uma imersão no campo compreensivo da saúde, Freitas, Minayo e Fontes (2011) e a leitura de Gadamer $(2006,2015)$ nos auxiliou na possibilidade de entender que esse é um tema que requer profundidade sobre o sentido de ser no mundo. Nessa dimensão, este estudo tenta colar a imagem e os significados desse problema para o sujeito que a representa. Dessa maneira, cuidar da saúde requer o re- 
conhecimento de um sujeito que discorre sobre sua obesidade cuja abertura de mundo o situa em seu universo sociocultural.

Sobre isso, recorda-se o estudo de Denise Silva (2012, p. 169) que discute a experiência do profissional de saúde na promoção da alimentação saudável como um conflito entre "o imponderável humano" versus "o conhecimento científico" na determinação da sua práxis. Enfatiza a importância de agregar ao conhecimento técnico científico a dimensão sociocultural do sujeito para compreender suas escolhas alimentares.

Dessa configuração, pensar a obesidade de nutricionistas é um convite a discutir suas escolhas alimentares inadequadas, seu sedentarismo, sua adaptação e compreensão sobre esse problema de saúde.

Para tanto, o estudo contempla narrativas de nutricionistas com obesidade em cuja experiência pessoal e profissional demonstram o conflito em associar conhecimento técnico cientifico e escolhas alimentares no cotidiano. Sobre esta problemática, observa-se a importância de destacar a cultura obesogênica e a luta interna desses personagens reais que vivenciam o conflito de serem gordos e profissionais da alimentação.

\section{Metodologia}

Contemplam-se informações da dissertação de mestrado da principal autora cuja pesquisa qualitativa foi realizada em espaços de trabalhos de nutricionistas obesas na cidade de Salvador, Bahia, no ano de 2014. Foram critérios de inclusão: profissão nutricionista, sexo feminino, ser e sentir-se obesa. Trata-se, pois, de um estudo que discute a obesidade e sua interferência na vida socioprofissional destas mulheres.

As nutricionistas entrevistadas indicaram outras colegas, constituindo uma seleção para a pesquisa, contando com a similaridade entre seus discursos. Buscou-se conhecer as escolhas alimentares e seus significados, na tentativa de compreender como estas mulheres interpretam sua obesidade frente às atuais demandas biosocioculturais e entre estas, o recorrente preconceito contra esta enfermidade no tecido social - o estigma. (GOFFMAN, 1993) Para uma análise minudente da interpretação das narrativas produzidas, buscou-se a leitura de Hans-George Gadamer: Verdade e Método, 2015, parágrafos 400-619, que tratam da compreensão e da interpretação das falas.

São destacadas entrevistas narrativas, realizadas com sete nutricionistas e para tanto, seguiu-se um roteiro de questões mínimas, valorizando-se 
fragmentos de suas histórias de vida (BERTAUX, 1993; TODOROV, 2013), suas escolhas alimentares e a percepção da condição de indivíduos portadores de obesidade. Seus nomes foram preservados, utilizando-se apenas fictícios, conforme acordado com elas.

Ao buscar o cotidiano do comer tão próximo, volta-se a atenção para o uso dos termos, obeso e gordo neste estudo, considerados sinônimos e que representam a linguagem ética das ciências naturais e êmica, própria do mundo pessoal e cotidiano, portanto sociocultural. O conflito entre o técnico-científico da formação da nutricionista e o cultural aparece como central neste estudo polissêmico sobre a obesidade na profissional de saúde.

A pesquisa foi aprovada pelo Comitê de Ética em Pesquisa da Faculdade de Medicina da Universidade Federal da Bahia (CEP/FMB/UFBA) em 4 de setembro de 2013 sob o n 383.530. Considerou-se a Resolução 466/12 do Conselho Nacional de Saúde (CNS).

\section{Resultados e discussão}

As mulheres entrevistadas contaram sobre a forma velada com que a sociedade lhes responsabiliza pelo corpo obeso sem considerar a dimensão sociocultural e seus ambientes de trabalho, que lhes impõem uma carga laboral extenuante e incompatível com a saúde.

As narrativas revelam suas tentativas de modelagem da vida e do corpo para atender ao padrão físico e alimentar socialmente esperado em função da autorização científica que lhes é conferida pela formação acadêmica, e a influência da subjetividade rompendo com essa lógica.

Ao discutir a dicotomia existente entre teoria e prática no contexto das mudanças alimentares, observa-se um desafio do modelo explicativo, dado a pluralidade de significantes culturais entrelaçados nesse campo temático da alimentação, como: hábitos, conduta, comportamento e escolhas. (DIEZ-GARCIA, 2012) A realidade dos sujeitos deste estudo mostra "escolhas alimentares" como a expressão compartilhada entre as protagonistas, para significar esse fenômeno sociocultural, do qual se sentem prisioneiras.

\section{Influência da família na formação dos hábitos alimentares}

A experiência dos sujeitos em seu mundo social desde a infância delineia-se sobre escolhas alimentares cotidianas que nutrem o corpo biológico e 
o sociocultural. As nutricionistas revelam seus hábitos alimentares resultantes de uma aprendizagem que se iniciou na infância e foi consolidada no contexto familiar:

Educação alimentar tem que vir muito cedo. E eu não tive isso. A culpa (da obesidade) é da minha família, de minha mãe. [...] Quando era criança, se eu chorasse ela dizia: tome aqui um chocolate! [...] E a culpa é minha também. Eu poderia ter mudado essa realidade e estar com uma dieta de $1.200 \mathrm{Kcal}$. Mas a verdade é que não aguento. Hoje eu não posso fazer essa dieta. (Beatriz, 30 anos)

A família, entendida por Beatriz, como a instância de referência de cuidado, assume o lugar da falta de apoio materno no que concerne à alimentação. Na sua experiência a expressão do afeto se dá com a oferta de doces.

A mãe aparece como a pessoa que acolhe o choro com guloseimas, ao tempo que gera um problema que se fará presente até a vida adulta, gerando nesta nutricionista o sofrimento por não conseguir romper com o aprendizado de comer de um modo não saudável. No lugar mais íntimo da sua vida, na sua base, no espaço familiar, Beatriz vê sedimentar a sua obesidade.

Esta autora relata uma vida marcada por rupturas entre o desejo de ser aceita, valorizada, respeitada e cuidada e suas possibilidades de responder às necessidades de mudança do hábito alimentar que lhe é exigido para ocupar esse lugar.

A narradora entende seu problema como uma dificuldade que aparece na infância com a mãe, a qual a condicionou a um modo de se alimentar que não consegue transgredir, mesmo com o conhecimento científico de que dispõe.

Vale frisar que seria importante uma análise mais profunda com o auxílio da psicologia, mas neste estudo, assinala-se um breve entendimento da obesidade sem adentrar singularidades no campo psíquico. Em contrapartida, adota-se a experiência de ser obesa como fundante do discurso que emerge para a pesquisadora, a intérprete. A fenomenologia descrita por Gadamer (2015) nos auxiliou na interpretação.

Outra nutricionista em estado de obesidade, Diana, também expressa a força dos aprendizados sobre o comer na infância. Ela narra sobre o excesso alimentar rotineiro ao recordar que o consumo de alimentos na família não era determinado pela necessidade biológica, mas pela compensação antecipada pelo medo da falta de alimentos. Condição traumática da história de 
vida de seu avô. Para ela, o aprendizado científico não foi capaz de modificar o apreendido sobre comer em excesso:

Meu avô foi refugiado de guerra e passou por privação alimentar. Então, lá em casa era assim: você sempre podia comer mais. Eu lembro meu avô dizendo "eu vou morrer de barriga cheia”. Foi a educação que a gente teve. Criança comendo muito era bom, era saudável, era bonito ser criança gordinha. Quanto mais se tinha, mais podia comer. E adulta sou assim também. Um estudo que li esses dias dizia que os pais de crianças gordinhas não veem as suas crianças obesas. E comigo era assim... achava que estava tudo bem e não me via gorda. (Diana, 47 anos)

Outras narrativas, como as de Candice e Jéssica, que seguem abaixo, apresentam fragmentos de memória sobre o conflito alimentar:

Sempre fui grande desde menina (faz gesto com os braços arqueados em volta do corpo). Aos seis anos fiz uma cirurgia e minha mãe queria que eu comesse tudo que tinha comido até então. Comecei a comer e a engordar. (Candice, 57 anos)

Minha mãe dizia que com fome ou não, tinha de comer. Chegava o horário dos intervalos das refeições, tinha de comer. (Jéssica, 47 anos)

$\mathrm{Na}$ vivência dessas mulheres, a figura materna em vários momentos narrativos representa o eixo simbólico do comer - ou a orientação do comer - em demasia. Criam-se hábitos, escolhas e horários.

Os exemplos aqui apresentados demonstram que um sentido específico - como o comer em excesso - faz vínculo com o acontecimento, a obesidade. Ao recorrer aos estudos sobre memória na obra Los usos de la memoria, de Todorov (2013), cada indivíduo pode recordar o ultraje como único, ou o mais ofensivo. As nutricionistas recordam suas 'infâncias obesas' como experiências permanentes e sempre em confronto com o tempo presente. A infância parece determinar a obesidade, em suas falas. Assim, entre dois planos temporais, para elas nenhuma dieta pode remediar seus corpos em obesidades.

$\mathrm{Na}$ dimensão técnico-científica espera-se que sejam atrizes-tradutoras do enredo acadêmico, mas estas não conseguem aplicá-lo em suas vidas cotidianas. A nutricionista para demonstrar conhecimento, precisa marcá-lo em seu corpo de modo contundente. Entretanto, essa marca não aparece, pois seus corpos estão fora dos padrões antropométricos e de aceitação so- 
cial. Na intersubjetividade das narrativas dessas mulheres surge então, com frequência, o conflito que sentem na imposição do discurso normativo da nutrição. (FREITAS et al., 2012)

Suas narrativas dispõem sobre a separação entre o saber técnico científico e as escolhas alimentares pessoais, cuja intencionalidade não reduz o conflito e permanece uma dualidade entre obesidade e norma.

\section{"Tenho uma cabeça de gorda"}

A partir das experiências das mulheres entrevistadas, a obesidade é "lugar” de identidade, pois representa afetividade, gosto, desejo, na dimensão simbólica, subjetiva.

Entender como os sujeitos "[...] se vêem [sic] e determinam os fenômenos sociais que os envolvem contribui para a superação do paradigma centrado na díade saúde/doença”. (CASTRO, 2011, p. 10) Com essa possibilidade, o corpo obeso é construído de acordo com a história e a cultura dos sujeitos, conforme se apresenta a seguir, em alguns momentos selecionados das entrevistas:

Tenho uma cabeça de gorda que foi doutrinada para isso a vida toda. É muito difícil fazer dieta porque implica crenças, aquilo que você acredita, implica que você está muito estressado e acaba encontrando uma forma de fazer o mais fácil. E o que é o mais fácil?É você comer uma torta de chocolate. (Beatriz, zo anos)

Fiz a cirurgia de redução de estômago e foi bom para minha saúde. Sou hipertensa e depois disso reduzi a quantidade de medicamentos, melhorei da artrose. Mas confesso: é desesperador! Tudo continua como antes, cabeça gorda policiada por um estômago pequenino que não deixa os olhos crescerem muito ao ver alimentos. (Rita, 62 anos)

“Cabeça gorda” é a metáfora da gula. O efeito dos sentidos do desejo de comer em demasia, compulsivamente.

Para Beatriz, comer é uma construção sociocultural e a escolha do alimento se refere à praticidade: a comida pronta e industrializada, e o desejo que surge com a habitualidade. Não se contemplam dimensões físico-químicas e biológicas dos alimentos, mas outras que respondem aos sentidos de prazer e ansiedade. 
Um dos fatores condicionantes da escolha alimentar é motivado pelo estresse no trabalho, segundo algumas. A resposta pode ser uma "torta de chocolate" para aliviar a ansiedade. Este alimento é convencionalmente tido como não saudável pela ciência da saúde, obesogênico. Um ícone de satisfação e guloseima, na cultura ocidental.

A comida está envolvida em todos os melhores momentos de nossas vidas. Natal: comida. Uma criança nasce: você dá um "bem-nascido" (doce), no casamento: 'bem-casado' (pequeno bolo envolto em papel decorativo). Com isso a pessoa que te dá comida está dizendo que vocêe é importante para ela. (Beatriz, 3o anos)

Eu gosto de comer (sorri), e de fazer comida. [...] Lá em casa a alimentação sempre foi farta. Lembro que teve uma fase de crise financeira, mas a comida era sempre de primeira. A gente tem essa relação com a comida: almoço de família, sentar todo mundo junto, começar a comer cedo, e no domingo, só se levanta da mesa às três horas da tarde. (Amália, 33 anos)

Araniz e Comelles (2007, p. 26, tradução nossa) dizem que "comer também é um modo de se comunicar e se identificar com outras pessoas". Algumas narrativas fazem correspondências com escritos de Cecil Helman (2009, p. 56), sobre o valor simbólico da comida nas relações sociais. Também Otto e Ribeiro (2012) quando falam sobre a combinação entre alimentação e afetividade.

Nesse entendimento, Beatriz e Amália assumem que o momento de comer junto é celebração, pertencimento ao grupo social, expressão de amor e amizade. As escolhas alimentares centralizam o encontro humano como um texto a tornar possível o comer para além de uma disciplina da ciência.

\section{O sentido das escolhas alimentares e dietéticas}

As nutricionistas deste estudo vivem sedentárias, lutando contra a escassez de tempo para realizarem atividades físicas e consumir uma alimentação cotidiana mais elaborada. Com isso, suas escolhas alimentares são as mais rápidas, e mais encontradas no mercado. Em geral, são ricas em massas à base de farinhas, como pães, biscoitos e salgadinhos, doces - refrigerantes, brigadeiros e tortas -, gorduras - frituras - e pobres em vegetais - saladas. 
Essa nutrição obesogênica da sociedade contemporânea, é difícil de ser afrontada e provoca uma segregação entre o estilo de vida desejado e o possível para estas mulheres e tantas outras pessoas, certamente. A distância entre suas vivências e idealidades provocam sensações de fracasso, frustração, que repercutem na identidade profissional, evocando o sentimento de culpa pela ruptura da imagem corporal socialmente esperada, ou seja, nutricionistas antropometricamente normais nos padrões populacionais mundiais.

Entretanto, a cena cotidiana é outra. A subjetividade está entrelaçada aos conhecimentos científicos limitando sua aplicação.

Se eu estiver nervosa, estressada, vou na geladeira e como tudo que tiver pela frente. Não importa se tem gosto bom ou ruim. Eu como gelado. Como tudo. Fico puxando os pedaços das comidas em pé na frente da geladeira. [...] Comia pra compensar. (Diná, 49 anos)

A cena, aparentemente grotesca, representa um comportamento alimentar afetado por emoções. (DIEZ-GARCIA, 2012) Come-se excessivamente para compensar algo que se perde? Algo que se deseja e não pode alcançar?

Ademais desses sentidos, o comer faz relação com outras disposições corporais:

No meu período pré-menstrual tenho necessidade de chocolate, guloseimas, doces, frituras. Nesse período muda a demanda, o comportamento. Fico mais ansiosa, mais agitada, mais desnorteada. [...] E como é que encara isso de uma nutricionista? Profissional de saúde com o conhecimento técnico, teoria? Mas, na prática, você é um ser humano como qualquer outro [...] Então, internamente, a gente fica naquela eterna luta. (Sônia, 42 anos)

Ao falar de si em relação ao comer excessivo, a narrativa recorre à terceira pessoa como se o sujeito deslizasse o problema do eu para o outro. A estrutura da linguagem vai além da superfície dos sentidos, e por isso, comer para estas mulheres obesas pode significar compensar, não ter mais controle de si, pois já "não dá conta" de regular, ou de "fazer dieta".

Comer pode ser um recurso em situações adversas, como o estresse, que varia de acordo com a capacidade do sujeito em lidar com as dificuldades do cotidiano (DIEZ-GARCIA, 2012), como acontece na experiência de Diana. 
Abaixo, observa-se a vivência de Jéssica com repertórios divergentes do que propõe a ciência da saúde e o incômodo por ser socialmente vista como uma pessoa que não pode existir fora da regência da racionalidade biomédica:

Eu como muito quando estou com algum problema. Faço mesmo transferência para o alimento. [...] Quanto maior a carência emocional, quanto mais triste estou, mais eu como. Mas, nutricionista é proibida de comer. Existe o julgar. O prato da nutricionista tem que ter salada. Tudo no prato dela tem uma dimensão maior. (Jéssica, 47 anos)

Para Jéssica o conflito entre teoria e prática no campo da nutrição se torna evidente. Justifica as escolhas excessivas e qualitativamente inadequadas por mudanças do estado emocional. Essa também é a realidade de Diana, que revela um descontrole sobre si, um domínio do alimento quando há uma instabilidade no campo da subjetividade, conforme se vê:

Tenho uma compulsão. Quando eu disparo para comer, eu como mesmo! (Diana, 47 anos)

Há um conflito que marca a experiência dessas mulheres: a cobrança social - e delas mesmas - para seguir as recomendações científicas do bem comer, e as impossibilidades de executar o ordenamento das ciências naturais. As nutricionistas deste estudo ao "vivenciar" a obesidade em si, em seu corpo, "ferem" a normalidade, o esperado, a racionalidade cientifica.

Há uma lente nas relações sociais que atribui ao profissional de saúde a responsabilidade de cumprir o difundido discurso normativo do saudável. Nesse sentido, o nutricionista assume socialmente o lugar de "vitrine da saúde" - aquele profissional que além de prescritor de dietas emagrecedoras, consome comidas "leves”, sendo associado à prática de atividade física na perspectiva da promoção da saúde e prevenção de agravos.

Como representante da norma, não pode haver espaço para comportamentos incoerentes com essa orientação em suas vidas cotidianas. Com isso, as nutricionistas que têm excesso de peso e uma alimentação distante dos requisitos cientificamente determinados tendem a sofrer com um mal-estar subjetivo.

Elas vivem numa sociedade obesogênica, - e consomem fast foods, doces, refrigerantes, frituras, salgadinhos, chocolates, como visto antes - 
mas são cobradas pela sociedade a caber em medidas corporais enquadradas. Para elas, essa busca pelo corpo, que valida seu status profissional, tem sido tão esgotante quanto inatingível.

Diante da sensação de que sua aparência física inscreve informações sobre sua competência técnica, essas mulheres se sentem pressionadas a manejar sua dieta e vigiar continuamente suas escolhas. Nesse sentido, veem a obesidade como um estado contra o qual precisam lutar, para que o corpo atinja a métrica fixada como normal. (CANGUILHEM, 2011)

Sobre isso, as nutricionistas narraram acerca de suas tentativas de perda de peso, no intuito de buscar maior aceitação sócio profissional:

Já fiz de tudo: dieta da lua, do sol, do mar, do mundo, da peste, do juízo, da falta dele, de tudo que você possa imaginar! Todas essas (dietas) da moda aí eu já fiz. (Beatriz, 30 anos)

Jáfiz (dieta) de revista. (Eduarda, 37 anos)

Na minha casa você acha livro da dieta de Duncan, de South Beach, de Atkins, dos Pontos. Tudo que lança eu compro, leio e faço. (Candice, 57 anos)

Já tomei um shake (substituto de refeição) muito divulgado na mídia, mas parei porque não acreditei muito que podia dar resultado. (Rita, 62 anos)

Mesmo sabendo sobre orientações científicas para modulação das escolhas alimentares que possam contribuir para o cuidado das pessoas acometidas pela obesidade, as nutricionistas entrevistadas revelaram conhecer e utilizar diversas dietas, sem cunho científico comprovado, na tentativa de perder peso. Na experiência delas essas escolhas foram determinadas pelo sofrimento diante da ineficácia técnica. Define-se a racionalidade moderna como inaugural, ou seja, um modo de organizar o conhecimento teórico frente às questões sociais. (LUZ, 2004) Saber e mundo se encontram em conflito desde muito.

A compreensão da obesidade é incompleta. E é consenso na comunidade de saúde a sua gravidade e complexidade. $\mathrm{O}$ estado de obesidade abre espaço para surgimento de angústia que pesa na vida dessas mulheres entrevistadas. E considerando a aflição que invade a existência dessas nutricionistas e possivelmente a outras pessoas sem formação acadêmica na área da saúde também acometidas pela obesidade. Pode-se pensar em ele- 
ger teorias das ciências humanas e sociais para colaborar no alargamento dos limites biomédicos para o tratamento desta questão que toca o mundo das subjetividades. Como vimos antes, elegem-se autores da fenomenologia para uma aproximação da existência obesa dessas nutricionistas colaboradoras desse estudo.

\section{Considerações finais}

Constata-se que há um forte conflito entre escolhas alimentares de nutricionistas obesas, seus discursos técnico-científicos referenciados na formação acadêmica em nutrição e o contexto de uma sociedade obesogênica. O estudo tenta mostrar a importância do tema que deve reunir as ciências da saúde e as sociais e humanas para que se possa continuar esta investigação de modo mais profundo.

A aflição das nutricionistas capaz de modificar suas escolhas alimentares indica a necessidade de (re)elaboração de cenas da vida cotidiana para obterem novos sentidos cognitivos representativos do ato de comer.

Como profissionais da saúde que cuidam da alimentação, elas carregam um paradoxo: de um lado, o desejo de seguir as normas técnicas que possibilitam preservar a saúde, e de outro o sentimento de "derrota” diante de sua própria condição obesa cujos condicionantes sociais são perversos. Nessa perspectiva, o estudo permite pensar a obesidade enquanto uma questão social complexa que envolve tessituras entre corpo, saúde, alimentação e sociedade.

A obesidade precisa ser considerada um assunto ético, diante do sofrimento humano que ela provoca. As narrativas das nutricionistas com obesidade sobre as dificuldades de modulação das escolhas alimentares, alinhadas às normativas científicas, convidam a uma sensibilização do olhar sobre a vida contemporânea e para os aspectos socioantropológicos da alimentação que podem explicar a presença dessa condição humana.

\section{Referências}

ARANIZ, M. G.; COMELLES, J. M. (Coord.). No comerás: narrativas sobre comida, cuerpo y género en el nuevo milenio. Barcelona: Icaria editorial, 2007 . 
BADZIAK, R. P. F.; MOURA, V.E.V. Determinantes sociais da saúde: um conceito para efetivação do direito à saúde. Revista de Saúde Pública de Santa Catarina, Florianópolis, v. 3, n. 1, p. 69-79, jan./jun. 2010.

BERTAUX, D. Los relatos de vida em el análises Social. In: LOZANO, J. E. A. Historia oral. Ciudad de México: Instituto Mora: Universidad Autónoma Metropolitana, 1993·p. 136-148.

BOURDIEU, P. O poder simbólico. Rio de Janeiro: Bertrand Brasil; Lisboa: Difel, 1989. (Série Memória e Sociedade).

BRASIL. Ministério da Saúde. Agência Nacional de Saúde Suplementar. Vigitel Brasil 2015 Saúde Suplementar: vigilância de fatores de risco e proteção para doenças crônicas por inquérito telefônico. Brasília, DF, 2017.

BRASIL. Ministério da Saúde. Secretaria de Atenção à Saúde. Diretrizes do NASF: núcleo de apoio a saúde da família. Brasília, DF, 20og. (Série A. Normas e manuais técnicos). (Cadernos de Atenção Básica, n. 27).

BRASIL. Ministério da Saúde. Secretaria de Atenção à Saúde. Departamento de Atenção Básica. Política nacional de alimentação e nutrição. Brasília, DF, 2012. (Série B. Textos Básicos de Saúde).

BRASIL. Ministério da Saúde. Secretaria de Atenção à Saúde. Departamento de Atenção Básica. Política nacional de práticas integrativas e complementares no SUS: atitude de ampliação de acesso. Brasília, DF, 20o6. (Série B. Textos Básicos de Saúde).

BRASIL. Ministério da Saúde. Secretaria de Vigilância em Saúde. Secretaria de Atenção à Saúde. Política nacional de promoção da saúde. 3. ed. Brasília, 201o. (Série B. Textos Básicos de Saúde). (Série Pactos pela Saúde 20o6, v. 7).

BRASIL. Obesidade atinge mais da metade da população brasileira, aponta estudo. 2013. Disponível em: <http://www.brasil.gov.br/saude/2013/o8/obesidade-atingemais-da-metade-da-populacao-brasileira-aponta-estudo $>$. Acesso em: 03 ago. 2017 .

CANGUILHEM, G. O normal e o patológico. Tradução de Maria Thereza Redig de Carvalho Barrocas. 7. ed. Rio de Janeiro: Forense Universitária, 2011.

CASTRO, H. C. Representações sociais da obesidade para mulheres em situações de pobreza. 2011. 44 f. Monografia (Graduação em Nutrição) - Faculdade de Medicina, Universidade Federal do Rio Grande do Sul, Porto Alegre, 2011. 
CONSELHO FEDERAL DE NUTRICIONISTAS CFN. Resolução CFN n ${ }^{\circ} 3^{80}$, de 28 de dezembro de 2005. Dispõe sobre a definição das áreas de atuação do nutricionista e suas atribuições, estabelece parâmetros numéricos de referência, por área de atuação, e dá outras providências. Diário Oficial [da] República Federativa do Brasil, Brasília, DF, 10 jan. 20o6. Seção 1, p. 66-71.

CONTRERAS, J. Teorias Antropológicas sobre Alimentação. In: CONTRERAS, J.; GRACIA, M. Alimentação, sociedade e cultura. Tradução de Mayra Fonseca e Bárbara AtieGuidalli. Rio de Janeiro: FIOCRUZ, 2011. p. 25-107.

COMISSÃO NACIONAL SOBRE OS DETERMINANTES SOCIAIS DA SAÚDE - CNDSS. Carta aberta aos candidatos à Presidência. Radis: comunicação em saúde, Rio de Janeiro, n. 49, set. 2oo6. Disponível em: <http://www6.ensp. fiocruz.br/radis/revista-radis/49/reportagens/comissao-nacional-sobredeterminantes-sociais-da-saude>. Acesso em: 14 dez. 2017.

DIEZ-GARCIA, R. W. Mudanças Alimentares: Implicações Práticas, Teóricas e Metodológicas. In: DIEZ-GARCIA, R. W.; CERVATO-MANCUSO, A. M. (Coord.). Mudanças alimentares e educação nutricional. Rio de Janeiro: Guanabara Koogan, 2012.

FREITAS, M. C. S. et al. Hábitos alimentares e os sentidos do comer. In: DIEZGARCIA, R. W.; CERVATO-MANCUSO, A. M. (Coord.). Mudanças alimentares e educação nutricional. Rio de Janeiro: Guanabara Koogan, 2012.

FREITAS, M. C. S.; MINAYO, M. C. S.; FONTES, G. A.V. Sobre o campo da alimentação e nutrição na perspectiva das teorias compreensivas. Ciência \& Saúde Coletiva, Rio de Janeiro, v. 16, n. 1, p. 31-38, jan. 2011.

GADAMER, H.-G. O caráter oculto da saúde. Petrópolis, RJ: Vozes, 2006.

GADAMER, H.-G. Verdade e método. Tradução de Flávio Paulo Meurer. 15. ed. Petrópolis, RJ: Vozes; Bragança Paulista, SP: EdUFS, 2015.

GOFFMAN, E. Estigma: la identidad deteriorada. Buenos Aires: Amorrortu, 1993 .

HELMAN, C. G. Dieta e nutrição. In: HELMAN, C. G. Cultura, saúde e doença. Tradução de Ane Rose Bolner. 5. ed. Porto Alegre: Artmed, 2009.

LUZ, M. T. Natural, racional, social: razão médica e racionalidade científica moderna. 2. ed. São Paulo: Hucitec, 2004.

MOTTA, D. G.; MOTTA, C. G.; CAMPOS, R. R. Teorias psicológicas da fundamentação do aconselhamento nutricional. In: DIEZ-GARCIA, R. W.; CERVATO-MANCUSO, A. M. (Coord.). Mudanças alimentares e educação nutricional. Rio de Janeiro: Guanabara Koogan, 2012. 
OTTO, A. F. N.; RIBEIRO, M. A. Unidos em torno da mesa: a dinâmica familiar na obesidade. Estudos de Psicologia, Natal, v. 17, n. 2, p. 255-263. maio/ago. 2012.

SILVA, D. O. Reflexões conceituais e de profissionais de saúde sobre a promoção da alimentação saudável. In: DIEZ-GARCIA, R. W.; CERVATO-MANCUSO, A. M. (Coord.). Mudanças alimentares e educação nutricional. Rio de Janeiro: Guanabara Koogan, 2012.

TODOROV, T. Los usos de la memoria. Buenos Aires: Museo de la Memoria y los Derechos Humanos, 2013. (Colección Signos de la Memoria).

WORLD HEALTH ORGANIZATION - WHO. Overwheigth and obesity. [201-]. Disponível em: <http:/www.who.int/gho/ncd/risk_factors/overweight_text/ en/>. Acesso em: o3 ago. 2017. 


\title{
Balbina de Jesus
}

\section{um estudo de caso sobre a organização do trabalho informal de feirante - concepção, execução e cuidado de si}

\author{
SAULO ROBLEDO CARDOSO \\ MARIA DO CARMO SOARES DE FREITAS \\ RITA DE CÁSSIA PEREIRA FERNANDES
}

\section{Introdução}

\begin{abstract}
Antes de vir pra feira eu morava no interior, trabalhava na cozinha "do branco" (com menos de 12 anos), depois descobri que tinha uma irmã em Salvador, vim procurar ela. Fiquei com ela [...]. O marido dela querendo me seduzir, eu larguei ela e fui trabalhar com um "coroa" que tinha idade de ser meu pai. Muita "cantiga” e eu acabei "caindo", eu tinha quatorze anos. Eu na minha inocência, tabaroa, chegada do interior sem experiência, caí naquele conto. A primeira coisa que me apareceu foi uma filha. Tenho uma filha de 43 anos. (Balbina)
\end{abstract}

Este estudo apresenta as condições de vida e trabalho de uma feirante, moedora da raiz de mandioca na Feira de São Joaquim, cidade do Salvador, Bahia. Antes de contar sobre sua vida e seu trabalho, faz-se um breve comentário histórico sobre a concepção de feira enquanto lugar de comercializar alimentos e outros objetos da vida cotidiana. 
Surgiram as feiras na Europa do século IX com o objetivo de suprir as populações dos aglomerados urbanos, de gêneros de primeira necessidade (PIRENNE, 1936), constituindo-se como um espaço onde:

Agregavam-se pequenos comerciantes, mercadores diversos, camponeses, artífices, mendigos, simples transeuntes, que ocupavam o espaço público, geralmente no centro das cidades ou nos seus bairros mais movimentados que muitas vezes se confundiam com a formação das próprias cidades. (PENA; THÉBAUD-MONY, 1995, p. 74)

A importância sociocultural e econômica desses espaços, ao longo do tempo, está na constituição de inúmeras atividades de trabalho. E para apreensão deste tipo de patrimônio social e humano é necessário estabelecer uma visão sistemática e crítica sobre o feirante e suas atividades, considerando as dimensões físicas, cognitivas e psíquicas do trabalho que refletem na saúde desses trabalhadores. Nesse sentido, é objetivo deste artigo apresentar o trabalho de ralação de mandioca a partir das concepções de uma feirante, Balbina de Jesus, há mais de 30 anos atuando na Feira de São Joaquim (FSJ), e a partir daí, refletir sobre a saúde dos feirantes.

Especificamente, descreve-se cuidadosamente um tipo de atividade que demanda mais de dez horas por dia, um exercício físico e mental do trabalhador, que resulta num esforço intenso dos braços, postura e atenção permanente sobre o funcionamento de uma máquina raladora de mandioca. Esta atividade é exercida há mais de seis anos por Balbina, criadora desta ferramenta artesanal utilizada cotidianamente.

\section{Metodologia}

A atividade de ralar mandioca desenvolvida por Balbina no ambiente da FSJ constitui o foco principal dos resultados apresentados aqui. Neste estudo de caso, a observação participante, os registros de campo, as entrevistas, tendo como referência a abordagem da Análise Ergonômica do Trabalho (AET), que permitiram inclusive a aproximação com a história de vida dessa trabalhadora, compõem o conjunto de ferramentas e a base metodológica e instrumental do desenvolvimento dessa pesquisa.

O contato com a teoria compreensiva, desenvolvida por Geertz (1989), com os estudos de Freitas, Minayo e Fontes (2011) e Minayo (2008), e com 
obras como A arte de contar e trocar experiências, de Souza (2006), e Memória e sociedade: lembranças de velhos, de Bosi (1994) contribuiram significativamente para o alcance dos objetivos deste estudo.

Destaca-se a importância da Análise Ergonômica do Trabalho (AET), que corroborou um exame detalhado dos processos organizacionais e relacionais, além de possibilitar uma melhor apreensão do contexto estudado, visando contribuir para o desenvolvimento do campo da saúde do trabalhador feirante e informal. Para esta abordagem metodológica, o estudo se apoia em autores como: Guérin e colaboradores (2001), Schwartz e Durrive (2007), Clot ([201-]), entre outros.

Schwartz (1999) propõe um modelo de compreensão do trabalho considerando três polos de análise. $\mathrm{O}$ primeiro comporta distintos materiais para o conhecimento do feirante, tais como, a distinção entre trabalho prescrito e real, que no ambiente da feira possui uma construção diferenciada do mercado de trabalho formal; a noção de mercado diante das limitações de escolarização; o corpo humano e o cuidado com o trabalho; práticas linguísticas e dificuldades de comunicação, pois nem sempre há palavras em suficiência para expressar os argumentos. O segundo diz respeito aos saberes gerados nas atividades: a experiência. $\mathrm{O}$ terceiro é a aprendizagem proporcionada no convívio com o outro, o semelhante. Na FSJ, observa-se fenômenos correspondentes aos mencionados por este autor, como será demonstrado no desenvolver deste trabalho.

Guérin e colaboradores (2001) trazem os conceitos centrais de tarefa e atividade ou trabalho real, que se basearam no estudo do trabalho feirante, e, em particular, o trabalho de Balbina. Nesta perspectiva da AET, a atividade se conforma em situação de trabalho e é entendida como o modo pelo qual o trabalhador se relaciona com os objetivos e com os meios disponíveis para realizar as tarefas. Neste contexto, ele se move, gesticula, olha, escuta, se comunica; organiza seu trabalho, planifica suas ações, raciocina, toma decisões, controla os resultados; além de colocar em ação suas funções fisiológicas e mentais.

Outra noção relevante da abordagem ergonômica do trabalho é a de variabilidade. $\mathrm{O}$ entendimento de que não há situação permanentemente estável de trabalho é fundante desta abordagem metodológica. Os sujeitos que trabalham são diversos - variabilidade inter e intraindividual, bem como as condições em que o trabalho é desenvolvido - variabilidade de 
processo ou de sistema de trabalho, variabilidade de materiais e de equipamentos. Para lidar com essa variabilidade, ou com as perturbações, que podem ser apreendidas como características estruturais do sistema de trabalho, os trabalhadores modificam os objetivos ou os meios disponíveis para assegurar a conclusão das tarefas, a qualidade do realizado, e ainda para minimizar os riscos à saúde. No entanto, essas regulações, ou estratégias adotadas individualmente ou coletivamente pelos trabalhadores, nem sempre são possíveis em situações de trabalho muito restritivas, em que a precariedade dos meios impõe a realização das tarefas sob estado de fadiga física e psíquica. Nessas circunstâncias, o adoecimento do trabalhador não é evento imprevisto e pode resultar de uma inter-relação complexa entre diversos fatores do trabalho e da regulação possivelmente adotada pelo trabalhador. (GUÉRIN et al., 2001)

Esses conceitos e noções para análise do trabalho nortearam os caminhos metodológicos do presente estudo.

Durante oito meses foram realizadas observações, registros, e uma série de entrevistas em profundidade com Balbina e outros trabalhadores que compartilham da atividade de ralar mandioca. Contudo, elegeu-se esta mulher como entrevistada principal para uma descrição mais densa desse fenômeno, por perceber em seus discursos significados mais contundentes sobre o contexto e seu trabalho. Para a análise minudente da sua ocupação, foi fundamental a aproximação com os fragmentos da sua história de vida, sobretudo a vida laboral. A partir da observação e do registro de imagens do cotidiano, constatou-se o esforço físico e mental empreendido por esta mulher e os passos que organizam sua atividade na máquina raladora de mandioca.

\section{Feira de São Joaquim - FSJ}

Antes mesmo de descrever a atividade de ralação da mandioca por Balbina, considera-se necessário apresentar a feira e a organização do trabalho feirante, em que se destacam saberes e outros dilemas de ordem política, social, legal e econômica, além do pertencimento à informalidade. Também, destaca-se a análise da atividade feirante com seu processo de desenvolvimento e as influências culturais.

A Feira de São Joaquim nasce na década de 1920, com o nome de Feira do Sete, por ocupar a frente do sétimo galpão da Companhia das Docas do 
Estado da Bahia (CODEBA), na qual se iniciou o processo de relação conturbada com os poderes públicos, inaugurado com o primeiro deslocamento desta feira para um local denominado de Bacia de Água de Meninos.

Entretanto, foram apontadas questões de saúde e segurança como razões para o poder público tentar extinguir as atividades dessa feira. Em setembro de 1964, ocorreu a maior investida atribuída pelos feirantes aos militares golpistas para a sua total extinção: a feira foi tragicamente vitimada por dois incêndios seguidos, que a destruíram completamente, conforme relatos dos antigos trabalhadores.

É nesse momento de conflito que ocorre o mais representativo enfrentamento entre o sindicato organizado pela união dos feirantes, - para a garantia dos direitos ao exercício de suas atividades - e o poder público. Os feirantes, através das suas lideranças sindicais, reivindicavam um novo espaço para a continuidade das suas atividades. Nesse mesmo ano (1964), o Governo do Estado concede o direito de uso de um terreno da União, na enseada de São Joaquim, a aproximadamente 300 metros da antiga feira. A concessão dada em caráter provisório teria a duração de 31 anos. Mas, na prática, a FSJ se estabeleceu, configurando-se como uma conquista efetiva dos feirantes. Segundo relato dos feirantes, em todo esse tempo, não houve qualquer auxílio do Estado. Passados mais de 40 anos, o governo finalmente apresenta um projeto de requalificação para a Feira de São Joaquim.

Souza (2010, p. 225), em seu estudo sociológico sobre as teias que envolvem a sobrevivência da Feira de São Joaquim, identifica que:

As formações sociais sempre têm a percepção da possibilidade de seu desaparecimento, identificado como o caos e a desordem. Em contextos de crise, ou ante ameaças, suas forças se mobilizam no sentido de impulsionar modos de recriação e renovação, flexibilização, barganhando ou negociando - como estratégias de sobrevivência.

Nesse sentido, entende-se que as atividades desses feirantes têm como referência duas grandes situações: a necessidade de reconstrução de antigas e precárias instalações e, por outro lado, dar conta do seu desenvolvimento humano para a superação das dificuldades econômicas, sociais e ocupacionais vivenciadas. 
Para a análise do atual estado da FSJ, apresentam-se dados contextuais acerca deste peculiar local de comercialização. Vale ressaltar que atualmente, com uma estrutura de $36.595 \mathrm{~m}^{2}$ e 3065 feirantes cadastrados, divididos entre 2165 em boxes e 906 em bancas, esta é a maior feira da cidade do Salvador. Recebe um público diário estimado em mais de 10.000 pessoas, entre compradores e visitantes (BAHIA, 2008), e, conforme relatos de representantes do Sindicato do Comércio Varejista de Feirantes e Ambulantes da Cidade do Salvador (Sindifeira), há ainda centenas de trabalhadores não cadastrados.

Em vias da conclusão do seu processo de tombamento, a FSJ é considerada berço de inúmeras manifestações culturais, de expressões artísticas, comidas típicas e produtos diversos. Representando o principal centro de comercialização do artesanato produzido no Recôncavo Baiano, além de animais vivos, hortifrutigranjeiros e artigos utilizados nos rituais das religiões de matriz africana da cidade de Salvador.

Entretanto, ao considerar os aspectos sanitários, observam-se valores da cultura que parecem negligenciar a saúde ambiental conforme os ditames da vigilância sanitária. Tudo parece sujo, feio e de mau cheiro. Veem-se restos de pescados, vísceras expostas, moscas sobre os alimentos etc. No chão, quase sempre enlameado, encontram-se verduras, legumes, animais vivos e abatidos. Em meio às atividades comerciais estão crianças (filhos e netos dos comerciantes), cachorros, gatos, ratos e o lixo que se acumula inevitavelmente no cenário feirante. Observa-se precárias condições no acondicionamento e na manipulação das mercadorias, numa clara demonstração de insegurança alimentar. Nem sempre há sanitários, quase sempre são adaptações nos fundos das pequenas barracas.

Essas e outras observações sobre riscos de contaminação ambiental e para a saúde dos trabalhadores e consumidores da feira confirmaram a necessidade de um novo modus operandi, capaz de apresentar melhorias efetivas no ambiente. Diante da ameaça de fechamento da feira por insalubridade pelo Ministério Público Estadual, o Governo do Estado apresentou como solução para o quadro acima relatado, o Projeto de Requalificação da Feira de São Joaquim (PRFSJ), em execução pela Secretaria Estadual do Turismo.

A intervenção do poder público na FSJ iniciou-se no ano de 2012, e trouxe à tona a discussão junto ao Sindifeira, sobre a necessidade de uma aproximação real das situações de trabalho peculiares nesse espaço. 
Entretanto, diante de um ambiente polifônico e polissêmico desse universo, com múltiplas funções de trabalho, é perceptível no projeto de requalificação da FSJ a ausência de uma análise segmentada, com vistas a proporcionar a compreensão e o desenvolvimento particular e coletivo desse lugar-feira.

A relevância do desenvolvimento de iniciativas voltadas à preservação de feiras livres diz respeito não apenas a questões socioeconômicas, mas, sobretudo, aos processos que envolvem a cultura de mercados públicos. Neste contexto, Pena e Thébaud-Mony (1995) chamam a atenção para a significância histórica da feira popular, onde se dá a circulação dos consumidores, $\mathrm{o}$ aspecto econômico de compras a baixo preço, as relações sociais de proximidade e a permanência de valores culturais e afetivos.

Do mesmo modo, a eficiência de projetos desta ordem depende das conexões entre o planejamento oficial e as reais necessidades dos beneficiários. Para valorizar a experiência desses trabalhadores feirantes, é preciso observar as diversas atividades consonantes a esse tipo de comércio, entendendo sua historicidade, a cultura e as estratégias de sobrevivência para a produção e venda de mercadorias, na sua grande maioria, processadas de modo semiartesanal. Um projeto governamental de requalificação dessa feira deveria, portanto, incluir aspectos para além dos estéticos e sanitários. Ver mais profundamente cada experiência singular desses feirantes.

Nessa perspectiva, este capítulo apresenta uma situação específica, como um estudo de caso no interior da FSJ que, ao descrever as tarefas e o trabalho real de uma feirante, lidando cotidianamente com restrições de naturezas diversas em situação de trabalho, evidencia as estratégias adotadas para viabilizar o trabalho e os riscos para a saúde pública e do trabalhador.

\section{Trabalho informal feirante, empreendedorismo e construção de saberes}

A ação ergonômica, enquanto objeto da transformação do trabalho, se dá por meio da interação entre as lógicas do social e da produção. Trata-se portanto de uma abordagem que vislumbra situações de trabalho que não causem danos à saúde dos operadores no exercício de suas competências, seja no plano individual ou coletivo, valorizando suas capacidades, além de proporcionar o alcance dos objetivos econômicos. (GUÉRIN et al., 2001) 
A atividade feirante, em geral, é considerada intensiva, com tecnologias pouco sofisticadas, vínculos de trabalho precários, dirigida às camadas médias e populares da sociedade. (SANTOS, 2004) A feira possui peculiaridades próprias da atividade informal, com distintas formas de produção no campo da compreensão do trabalho feirante. Os conhecimentos da análise ergonômica do trabalho aplicados à atividade feirante podem evidenciar diversas situações de ordem cultural, social, econômica e humana, conforme serão apresentadas neste estudo. A dinâmica da FSJ gera inclusão e exclusão de trabalhadores. Essa dinâmica impõe a esses trabalhadores esforços visando à manutenção do seu comércio, da sua sobrevivência e de sua família.

A FSJ se constituiu em um referencial culturalmente estabelecido para a população mais carente da cidade do Salvador, região metropolitana e Recôncavo Baiano, enquanto local de troca de força de trabalho por alimentos ou pequenas remunerações, ofertadas por pequenos e médios comerciantes. Desse modo, observam-se trabalhadores de distintas camadas sociais, dos mais pobres aos níveis médios de renda e trabalho, conformando um cenário de movimento diário na garantia da sobrevivência. Contudo, na complexidade dessas atividades, também se inscrevem exclusão e estigma, pois, como a FSJ é mais valorizada pelas camadas mais baixas da sociedade, há sempre o receio dos feirantes de que eventuais mudanças neste cenário possam representar ameaças aos seus postos de trabalho diante da percepção de desvalorização com que os setores da economia formal os veem.

Nesse sentido, observa-se que os trabalhadores se especializam e cooperam entre si num claro propósito de pertencimento e identidade do território de produção, tanto individual quanto coletivo. Este movimento pode ser compreendido como autonomia e automobilização do indivíduo, conforme estudo de Zarifian (2001), ao definir competência, iniciativa e responsabilidade diante de situações laborais. Essas, na feira em estudo, foram registradas como estratégias de produção e acordos entre os parceiros.

Nesta perspectiva, vale destacar as negociações com fregueses e fornecedores, a busca por melhor apresentação do produto final, as parcerias com trabalhadores de outras atividades, a compreensão da atividade do outro, enquanto referencial para o melhor desenvolvimento de seu trabalho, dentre tantas abordagens reconhecidas como saber-fazer e saber-ser feirante.

Saber-fazer é concernente ao domínio das ferramentas, ao funcionamento das máquinas, procedimentos ordinários ou extraordinários, respos- 
tas a demandas particulares dos usuários e aos métodos em contextos bem específicos. (ASSUNÇÃO, 2003) Saber-ser recobre o conjunto de comportamentos de adaptação, relações com o outro, os contornos variáveis das demandas apresentadas pelas condições de trabalho flutuantes e a relação com os diferentes usuários e clientes que demandam serviços. (MINET, 1995)

Ambos os saberes se entrecruzam na habilidade em que a cognição ambiental abarca percepção, memória, atitudes e preferências humanas, além de outros fatores psicossociais. Nesse aspecto, os espaços de referências são organizados e decodificados para serem incorporados à memória e às estruturas de representação. (SERPA, 2007) Por esta razão, os pequenos espaços de cada comerciante da FSJ se mantêm, constituindo-se em referências de vizinhança e freguesias.

Característica da atividade informal feirante, a autonomia é, sem dúvida, um dos mais significativos objetos deste estudo, principalmente no que tange à compreensão laboral desenvolvida por eles mesmos: concepção da atividade, execução e cuidado de si. A concepção da atividade aqui analisada não se refere somente ao indubitável poder criativo desses trabalhadores, que em meio às demandas caóticas da informalidade feirante, desenvolvem estratégias de superação e reinventam outras, mas, sobretudo, há uma compreensão do outro, enquanto colaborador do seu desenvolvimento, mesmo diante dos inevitáveis conflitos.

Para a análise da execução da atividade, faz-se necessário ter em conta a noção de gestão e questionar o modo como o trabalhador feirante consegue dar conta de uma heterogeneidade de aspectos relacionados à construção do seu trabalho. Ou seja, como consegue gerenciar as demandas específicas do ofício, que se apresentam em meio à busca dos objetivos da atividade; as interfaces; montante, jusante e laterais; a concepção dos orçamentos e dos tempos, dos indicadores econômicos de desempenho e das relações humanas e sociais. (SCHWARTZ, 2004) Cada detalhe do conjunto de objetos que formam suas atividades são inscrições da cultura da feira, que se apoiam na rotina, na experiência e memória viva de um cotidiano que sempre se renova. Desse modo, cuidam de si, no sentido de minimizarem impactos à saúde.

$\mathrm{O}$ trabalho informal feirante reúne um conjunto de atividades que são desenvolvidas em sua maioria de modo empírico, constituídas a partir da relação com: o ambiente, trabalhadores, sociedade, demandas sociais, cul- 
turais, políticas e econômicas, tanto no âmbito particular quanto no coletivo das representações das atividades.

Para melhor detalhar esse desenvolvimento na FSJ, inspirado no dispositivo de três polos proposto por Schwartz (1999), adota-se aqui um modelo de análise do trabalho informal feirante através de uma abordagem denominada de Redes Co-labor-ativas Inclusivas da Atividade Feirante Informal. Estas redes são constituídas a partir da premissa de que na feira a co-labor-ação é o principal instrumento para conceber, implementar e desenvolver atividades capazes de garantir a sobrevivência dos indivíduos através da preservação dos coletivos.

Observa-se que na FSJ essas redes co-labor-ativas se apresentam de diferentes formas e estágios, mantendo um ciclo orgânico retroalimentado por três bases, a coinclusão, a coeducação e a cooperação. A inclusão de membros da comunidade, as aprendizagens, as relações familiares, comerciais e a cooperação são representações marcantes do cotidiano da FSJ, no que concerne à esfera econômica, cultural, social, política e humana. Desses pressupostos, descreve-se a seguir as observações do caso em estudo.

\section{O trabalho de ralação de mandioca e seu contexto - uma descrição etnográfica}

No interior desta feira, entre as ruelas longas e estreitas, surge uma pequena canaleta por onde escorre a água da limpeza de alguns boxes e da chuva. Bem junto dessa canaleta e sobre um chão escorregadio e recoberto por uma camada fina de lama, encontra-se a máquina de ralar mandioca construída por Balbina. Mantida acorrentada ao lado de uma pequena barraca de $4 \mathrm{~m}^{2}$, esse equipamento de ferro e alumínio, em formato de trapézio, tem na lateral direita superior uma bandeja de entrada e na esquerda um saco transparente acoplado a um balde receptor do produto final: a massa de mandioca. $\mathrm{O}$ principal componente deste equipamento é o cilindro de ralação. Uma peça formada por cerdas pontiagudas de metal que através do processo de rotação acelerada possibilitam a ralação da mandioca.

“Essa máquina é meu pai, minha mãe”, diz Balbina, ao terminar sua demonstração de ralar mandioca na máquina. Depois, lava tudo enquanto conversa sobre sua experiência. Descansa uns dez minutos e reinicia sua tarefa de ralação das raízes da mandioca descascadas, limpas e selecionadas. Estas ficam dispos- 
tas longitudinalmente e enfileiradas sobre a bandeja de entrada da máquina, que, ao ser acionada, dá início ao processo de ralação e produção da massa.

A agilidade demonstrada por Balbina é capaz de impressionar tanto os parceiros de feira, quanto os visitantes, compradores habituais, transeuntes, que não escondem a curiosidade de saber sobre esta atividade de ruído perturbador. Com um olhar atento ao conjunto de tarefas que compõem a ralação, Balbina promove nos espectadores momentos de aflição, ao demonstrar a funcionalidade da máquina ao mesmo tempo em que cumprimenta amigos e negocia com fregueses.

Raiz por raiz, Balbina retoma a tarefa de ralação da mandioca, mesmo evidenciando visíveis sinais de exaustão. Por vezes alonga o corpo, sacode os braços, interrompe a ralação e para. De maneira extraordinariamente envolvida, parece animada e atende aos fregueses. E tudo recomeça outra vez.

Balbina criou essa máquina a partir da junção de um motor para processamento de mandioca e um cilindro ralador, que encomendou na cidade de Santo Antonio de Jesus, no Recôncavo Baiano. Todos os demais itens que compõem o equipamento foram adaptados por ela: a estrutura de ferro, que constitui o esqueleto do instrumento, bem como as madeiras, as folhas de alumínio que revestem a estrutura e a bandeja de entrada.

A construção desse equipamento nasceu a partir da necessidade de produzir a massa da mandioca, de maneira mais rápida e menos desgastante. Produto muito procurado na culinária nordestina, matéria-prima para bolos e outras iguarias, antes produzida manualmente, há muito garante $\mathrm{o}$ seu sustento. "Eu aprendi a desenvolver isso com cara, coragem e força de vontade, porque quem não tem estudo tem que ir à luta, tem que descobrir de onde vaiganhar o pão de cada dia", conta a mulher de quase 60 anos, mãe de duas filhas, enquanto ensaca a massa em pequenos volumes de um quilo.

Ao relatar fragmentos de sua história de vida, relembra que sofreu discriminações durante a juventude. Quando estava só, com uma filha para criar e sem qualquer estudo, teve que trabalhar em várias atividades dentro do ambiente da feira. "Pra mim não tinha tempo ruim, já descarreguei caminhão, vendi montinho, carreguei balaio, fiz de tudo um pouco aqui na feira. Só não aprendi a me prostituir e a roubar, porque isso eu não procurei aprender".

Não se trata de um estudo sobre a compreensão de gênero no trabalho da FSJ, nem mesmo da representação política das mulheres e seus processos em relação aos homens da feira. Mas de uma investigação sobre as condi- 
ções de trabalho de uma mulher e sua experiência de viver como feirante num contexto de dominação masculina. Sobre isso, ela se orgulha de sua inserção na feira onde se sente igual aos homens. E, em seu discurso, observa-se o sentido de força moral em se manter no mundo circundante da feira, no qual se identifica problemas e age de modo prático e objetivo para garantir sua sobrevivência, como aparece em vários momentos deste estudo.

Com o passar do tempo e a soma dos seus esforços, Balbina chegou a ser proprietária de três miniboxes na FSJ, quando vendia flores de artesanato, uma "grande paixão e frustração", pois, não conseguiu sobreviver só com a arte. As somas de diversas dificuldades de ordem familiar e econômica levam a perder tudo o que havia conquistado. A ralação de mandioca representou a retomada da trajetória de Balbina na garantia da sua sobrevivência enquanto feirante e do sustento da sua família, inclusive ressignificando as suas noções comerciais. "Meu fraco é artesanato, mas não tenho tempo, porque artesã faz e tem que esperar o tempo de vender pra poder comer. Eu descobri que na massa, no material pra bolo, todo dia eu vendo".

“Aqui ninguém se importa com a gente”, diz Balbina, referindo-se às condições precárias da FSJ, o descaso do poder público e das autoridades. Em tom de indignação, salienta a insalubridade no ambiente da feira: "Quando chego em casa, lavo meus pés com limão e queimo com álcool. Vocêsabe, que a gente pega as coisas até pelo cheiro", destaca. O seu espaço de trabalho é um lugar negligenciado pelo poder público e todo seu esforço em manter seu pequeno comércio limpo não resulta em salubridade, pois esta depende de estruturas maiores, como saneamento básico e coleta de lixo permanente.

Numa demonstração de cuidado com sua atividade, no que tange ao estabelecimento das relações de afetividade com seus clientes, essa mulher semianalfabeta, e com uma marca de ter sido abandonada aos 12 anos de idade na feira, oferece a todos suas receitas de bolos, além de acolher seus fregueses com calorosas conversas de feira, no qual tudo é história e risos.

\section{A ralação de mandioca: executando as tarefas, constituindo a atividade}

A atividade de ralação mecânica de mandioca é uma das inúmeras na FSJ. A escolha dessa como objeto de análise se deu em virtude do conjunto de elementos que a constituem, do seu caráter inaugural e da representatividade da trabalhadora feirante frente a essa atividade. Inúmeros aspectos e 
peculiaridades desta atividade possibilitam a sua observação sob a luz dos conhecimentos da AET.

Como ponto de partida, algumas questões que se apresentam ao campo da AET norteiam o estudo: como se constrói e se estabelece no trabalho informal feirante esta atividade e, de que forma seria possível promover a redução de danos à saúde da operadora? O trabalho informal feirante, por ter em sua base constitutiva o empirismo, possui a peculiar estrutura de autonomia e, no caso específico desta atividade na FSJ, se encontra à margem de marcos regulatórios. É importante compreender que a relação tarefa, atividade e saúde se estabelece a partir da organização pelos próprios operadores com as inúmeras restrições que exigem a reinvenção todo o tempo.

Alinhado a esse contexto do trabalho, Balbina, em sua prática laboral, remonta sua história de vida. Antes, vale dizer que a busca por construções que sustentam o significado do termo tarefa possibilita compreender as demandas e percepções de impacto à saúde, sentidas por Balbina. As ações abaixo especificadas foram escolhidas por fazerem parte da partitura da ação de ralar mandioca. Os demais produtos comercializados por ela, originais de outros produtores, serão apresentados na tarefa de vendas.

Desse modo, o caso de Balbina mostra que são tomadas como tarefas; a abertura e a preparação do estabelecimento comercial; a compra das raízes; o descasque e a lavagem destas; a ralação da mandioca e a venda dos produtos. Para a execução dessas tarefas nas condições reais, Balbina interage com os diversos fatores que constituem a situação de trabalho, regulando os objetivos e meios disponíveis, lidando com as variabilidades do sistema de trabalho e dos sujeitos em seu entorno para conformar o seu trabalho real ou atividade. A seguir mostram-se os passos dessas tarefas e a constituição da atividade, no cotidiano laboral empreendido por Balbina.

\section{Abertura e preparação do estabelecimento comercial}

Ao chegar à feira, por volta das cinco horas da manhã, Balbina, acompanhada de seu sobrinho que é também seu funcionário, inicia a abertura do seu estabelecimento comercial, retirando lonas, cordas, correntes e cadeados utilizados para a garantia da segurança do equipamento. Baldes de água são carregados para dar início à limpeza do espaço interno da banca, do balcão, da máquina, dos demais instrumentos usados na ralação e da área do entorno. Na sequência, ela efetua a arrumação dos produtos que 
restaram do dia anterior e outros adquiridos para revender como a farinha de puba e a carimã, também derivadas de mandioca.

\section{Compra das raízes}

A compra das raízes é o momento chave, pois diz respeito à escolha da matéria-prima para sua produção. Balbina segue um percurso de aproximadamente quinhentos metros entre sua banca e o fundo da feira, percorrendo um verdadeiro labirinto formado pelos inúmeros becos e passagens no emaranhado da feira. Em seguida, inicia-se a negociação com cada um dos fornecedores de mandioca em seus caminhões. É parte da negociação a vistoria da mercadoria, através da quebra de algumas raízes, e ajuste do preço. Balbina necessariamente passa por todos os fornecedores do dia, em geral, são cinco: “De manhã cedo eu passo, mas não pego logo. Olho o movimento, as mercadorias, se está podre, apreço em um, em outro. Um dia compro num caminhão, um dia no outro, pra eles não botarem banca”.

Sobre essa estratégia, Balbina afirma que em períodos de escassez, os fornecedores tendem a aumentar os valores das mercadorias e que, com a compra sistemática com todos eles, cada dia com um, ela garante menores preços em períodos de crise.

\section{Descasque e lavagem das raízes}

Para o processo de descasque e lavagem das raízes, Balbina conta com o trabalho terceirizado de mulheres que disponibilizam a sua força de trabalho na feira. O número de contratadas varia de acordo com a quantidade de sacos de mandioca a serem descascados. Esta é uma das partes mais críticas do seu negócio, no que diz respeito às demandas psicoafetivas, por conta de o pagamento estar atrelado à quantidade de sacos descascados. Em virtude disso, e da existência de um fluxo maior de venda pela manhã, o que impõe a necessidade de que as raízes sejam descascadas com maior rapidez, Balbina precisa gerir esse processo através da contratação de mais mulheres. Esta ação adotada por ela provoca insatisfação nas mulheres que já executavam a atividade, pois a essas se inflige o imperativo de redimensionamento das suas expectativas de ganho, tendo que repartir as unidades de raízes com as recém-contratadas.

A esse fenômeno, atribui-se a compreensão de que fazendo escolhas engajamos outros trabalhadores, que, por sua vez, remetem a estatutos 
diversos. Por isso, em geral, não há um trabalhador isolado, pois outros estão lá através da preparação do trabalho, da prescrição e da avaliação. (SCHWARTZ; DURRIVE, p. 193, 2007)

\section{A ralação da mandioca - e a centralidade deste saber- fazer de Balbina}

O processo de ralação é iniciado com a troca da água do barril, no qual as raízes descascadas são acondicionadas. O processo de imersão na água possibilita tanto a limpeza das raízes, permitindo a visualização de falhas no descasque, que são corrigidas por Balbina, quanto o amolecimento das mesmas para o seu processamento. Em seguida, as raízes vão sendo colocadas na bandeja de entrada da máquina e inicia-se o procedimento de manuseio da máquina, atividade que demanda da operadora uma carga de atenção, força e destreza. Em simultâneo a tudo isso, Balbina concilia e articula ações de ordem social, administrativa e profissionais.

Uma vez ligada à máquina, o seu motor produz um intenso ruído, que Balbina diz estar acostumada. Ela não usa qualquer equipamento de proteção auricular. Durante a tarefa, que lhe exige agilidade e sincronicidade na disposição das raízes de mandioca na bandeja, são lançadas pequenas porções de massa sobre a sua face, e ainda assim, nenhum tipo de proteção ocular é utilizado por ela. Apenas uma tábua, sustentada por uma das mãos, é usada como escudo. A outra mão alterna entre a retirada de raízes lavadas de dentro do barril e a colocação dessas na bandeja da máquina, pressionando-as para o cilindro. Tudo é rápido e tenso. Toda a atenção é necessária no sentido de evitar a ocorrência de acidentes. Mas o risco é evidente. As cicatrizes de lesões dos seus dedos evidenciam o perigo da atividade.

A observação dos detalhes permite registrar as peculiaridades do método empregado por Balbina. Antes de ligar a máquina, ela verifica o interruptor que fica ao lado do equipamento, na altura da sua cabeça, a limpeza e as posições dos objetos - balde, saco plástico, barril com as raízes mergulhadas em água e bandeja. A segunda fase de ralação é composta por um período prolongado, compreendido entre o acionamento da máquina e o total enchimento do balde com a massa ralada. Após a execução de 20 minutos da tarefa, são perceptíveis os sinais de desconforto e fadiga, provocados pela postura de semiflexão do tronco para empurrar a mandioca contra o cilindro, com uma demanda de força na região paravertebral do dorso. Este es- 
forço é atenuado com o descanso das pernas, por meio de sua alternância em semiflexão do joelho, e da retomada da posição ereta do seu tronco, a cada parada por cerca de dez minutos.

Ao final do processo, braços e mãos ficam recobertos de resíduos de massa processada. Ela retira o excesso de mandioca da tábua e lança sobre a bandeja de entrada das raízes. Recolhe o saco acoplado com a massa ralada e, com um olhar orgulhosamente dadivoso, reafirma: "essa máquina é meu tudo. Deus me abençoou quando eu criei essa gerigonça. Olhe pra aqui, fininha”, diz ela, ao se referir à qualidade da massa. "A melhor da feira”, complementa um freguês.

\section{Venda da massa ralada}

Para o processo de venda da massa, Balbina executa as seguintes tarefas: preparação, exposição do produto e fidelização dos clientes. Na preparação do produto para a venda, ela utiliza a balança da barraca vizinha para pesar a primeira porção da massa, numa fração de um quilo. Esta é a única porção estabelecida com o uso da balança. Todas as demais serão medidas por meio de uma técnica denominada por Balbina como "de olho".

Com relação à promoção do produto, Balbina expõe as massas no balcão de maneira organizada, bem como seus bolos de aipim, carimã e puba. Concomitantemente, também fideliza seus clientes com tratamento personalizado por meio de informações sobre acondicionamento, validade e outros usos da massa como em pudins, biscoitos, mingaus e beijus. Irradia simpatia com conversa sobre sua experiência de viver na feira, criar filhos e seus casos de amor. Principalmente histórias sobre seu marido, morto recentemente, e de quem declara sentir falta. Para um dos clientes que aguarda atendimento, ela diz: “Pega dois quilos de aipim pra meu amigão aqui. No capricho! É três, é? Bota quatro pra ele meu filho”. Tudo é graça no pequeno comércio de Balbina.

\section{Do uso ao cuidado de si}

Outra questão a ser tomada em conta sobre o trabalho informal feirante refere-se ao que Schwartz e Durrive (2007) assinalam concordantes com Guérin e colaboradores (2001), sobre a variabilidade do meio ambiente onde o trabalho ocorre. 
Ele jamais se repete exatamente de um dia para o outro, ou de uma situação de trabalho para outra. Então, aí está uma primeira infidelidade do meio. Cada pessoa vai tentar 'lidar com' as lacunas ou as deficiências a seu modo, pois ela não pode fazê-lo de uma maneira padronizada. Ela o faz com sua história, seus próprios valores. E ao mesmo tempo ela vai contribuir ainda mais para singularizar o meio, para dar uma fonte de variabilidade suplementar. (SCHWARTZ, DURRIVE, 2007, p. 191)

Dada a estrutura da feira livre, com seus informais autônomos criativos e suas infiéis estruturas de trabalho variáveis, por natureza, impõe-se a questão de como, diante deste cenário, ainda ser possível cuidar de si.

Diferentemente dos trabalhadores formais, que têm ações de prevenção e outras garantias ao menos normatizadas. Na feira há uma completa ausência de políticas que reconheçam a importância histórica de suas atividades informais. Sem reconhecimento legal e sem promoção à saúde, esses trabalhadores se consideram "sem direito à nada" na difícil tarefa de se cuidar.

O saber-fazer, desenvolvido no cotidiano do trabalho na feira, evidenciou-se como o recurso mais precioso a assegurar a sobrevivência e o futuro incerto. Em meio à precariedade das condições de trabalho e frente à ausência da proteção e seguridade social, Balbina se prepara para o imponderável.

Sendo ela portadora de diabetes e ao saber que essa doença pode provocar retinopatia e levá-la à cegueira, diz "se algum dia me faltar a visão então eu passo no teste, porque só preciso da mão e do tato para trabalhar na minha máqui$n a$ ". De maneira surpreendente, e implicada com o seu trabalho, ela inicia o mais extraordinário uso de si, com toda a sua dramática existência, apresenta a possibilidade de realização da sua atividade ainda que acometida por uma limitação visual. Numa clara exibição da fusão entre a necessidade do cumprimento da tarefa e a perícia para realizá-la, ela liga o equipamento, em seguida, de olhos cerrados, elabora corporalmente a melhor forma de aproximação do cilindro motorizado, iniciando uma manobra dotada de elevado potencial de risco e capaz de provocar aflição nos espectadores da cena. “Repare, vou fazer essa base aqui oh", diz ela, mostrando o tamanho da raiz em relação à distância do cilindro. Em seguida, durante aproximadamente um minuto e meio, opera a máquina com os olhos fechados. "De olho fechado, eu já sei até quando posso levar a mão e quando eu posso parar”. 
Convergente com essa perspectiva, Balbina apresenta três exemplos particulares e referenciais do seu histórico ocupacional de se cuidar, em meio à sua atividade de trabalhadora feirante informal: cuidar de sobreviver economicamente; cuidar de ser mulher num ambiente masculino; e cuidar de ser operadora da máquina raladora desenvolvida por ela. Sobreviver, para Balbina, significa a base elementar de todo trabalhador feirante. Provocada sobre essa perspectiva, ela relembra a sua última crise financeira:

Com todas as dividas e o acidente do filho do meu marido, eu disse: meu Deus, o que é que eu vou fazer da vida? Aí eu pedi uma "bola" (cilindro ralador que compõe a máquina) a um rapaz de Santo Antônio de Jesus. Eu vou botar um aipim pra ralar aqui, ninguém tem e eu vou fazer sucesso com ele. Daí cheguei na Feira do Pau comprei um motor seminovo por 60,00 "Cruzeiros". O pessoal não sabia como fazer bolo de aipim e eu comecei. Aí nasceu o meu novo processo de sobrevivência.

[...] eles diziam: "oh mulher, isso aqui é trabalho de homem." Aí eu dizia, eu não estou pedindo nada, eu só quero trabalhar, tenho minha filha pra dar comida e não estou pedindo nada. Eles diziam assim: "essa mulher é mulher-homem, bota essa miserável para cima do caminhão pra ela pegar sozinha que ela desiste logo.” Aí eu dizia, tudo bem! Então eles ficavam de formiguinha e eu em cima. Naquela época eu tinha uma força que eu não sei, era carregada por Deus, às vezes eu pegava de dois, sessenta (peso em $\mathrm{kg}$ de cada saco), sessenta, cento e vinte... Aí eu pegava assim. Ejogava nas costas deles, um atrás do outro... Aí na hora de dividir eles queriam me dar merreca... Eu dizia que quem trabalhou mais fui eu, ai era um pau pra quebrar, mas acabava dividindo meio a meio.

Cuidou-se como pôde. Tantas vezes sozinha, outras vezes com seus pares. Sofreu maus tratos, assédios e discriminações. Para ela isso é ser mulher feirante. Hoje, respeitada e cansada, entende que está resguardada. Ninguém a perturba mais. Para isso, teve que ser "valente" e "mulher-homem”. Nunca fraquejar.

\section{Considerações finais}

Este estudo de caso sobre Balbina e sua atividade tenta exemplificar o peculiar, a observação situacional, o trabalho real e a saúde ocupacional do feirante. Nesse contexto, a ralação de mandioca é apenas um item das muitas formas de garantir a vida e o trabalho na FSJ. 
Buscou-se estabelecer relações entre o contexto físico e social e a atividade situada de uma trabalhadora feirante, considerando sua dinâmica própria, a organização temporal e espacial na qual as tarefas eram executadas.

As precárias estruturas para execução do trabalho nesta feira, aliadas às estratégias autônomas de regulação para viabilização da produção, requerem a compreensão do modus operandi do mundo do trabalho feirense, que poderia se abrir e contribuir para o campo da saúde do trabalhador feirante.

Evidenciou-se que intervenções a serem adotadas no mundo do trabalho feirante não podem prescindir a experiência dos sujeitos, o saber prático construído cotidianamente, que modula, na situação real de trabalho, a complexa realidade de sobreviver, produzir e se expor aos fatores de risco.

Nesse domínio, na FSJ, há ainda muito o que se apreender e construir.

\section{Referência}

ASSUNÇÃO, A. A. O saber prático construído pela experiência compensa as deficiências provocadas pelas condições inadequadas de trabalho. Trabalho \& Educação, Belo Horizonte, v. 12, n. 1, p. 35-49, 2003.

BAHIA. Secretaria de Cultura. Instituto do Patrimônio Artístico Cultural da Bahia. Projeto de Requalificação da Feira de São Joaquim, cadastramento 2008. Salvador, 2008.

BOSI, E. Memória e sociedade: lembranças de velhos. 13. ed. São Paulo: Companhia das Letras, 1994 .

CLOT, Y. Clínica do trabalho, clínica do real. São Paulo: UNIFESP, [201-]. Disponível em: <http://www.pqv.unifesp.br/clotClindotrab-tradkslb.pdf >. Acesso em: 25 maio 2012.

FREITAS, M. C. S.; MINAYO, M. C. S.; FONTES, G. A.V. Sobre o campo da alimentação e nutrição na perspectiva das teorias compreensivas. Ciência \& saúde coletiva, Rio de Janeiro, v. 16, n. 1, p. 31-38, jan. 2011.

GEERTZ, C. A interpretação das culturas. Rio de Janeiro: Guanabara Koogan, 1989.

GUÉRIN, F. et al. Compreendendo o trabalho para transformá-lo: a prática da ergonomia. São Paulo: Blücher, 2001.

MINAYO, M. C. S. Ciência, técnica e arte: o desafio da pesquisa social. In: MINAYO, M.C.S. (Org.). Pesquisa social: teoria, método e criatividade. 23. ed. Petrópolis, RJ: Vozes, 2004·p. 9-29. 
MINAYO, M. C. S. O desafio do conhecimento: pesquisa qualitativa em saúde.11. ed. São Paulo: Hucitec, 2008.

MINET, F. L'analyse de l'activité et la formation dês compétences. Paris: Éd. I’Harmattan, 1995 .

PENA, P. G. L.; THÉBAUD-MONY, A. Transformações organizacionais e inovações técnicas em hipermercados na França e no Brasil: a emergência do hipercontrole nos espaços de trabalho e consumo. In: DIEESE; CESIT (Org.). Trabalho e abordagem pluridisciplinar: estudos Brasil, França e Argentina. São Paulo, 1995. p. 69-108.

PIRENNE, H. Economic and Social History of Medieval Europe. New York: A Harvest Book, 1936.

SANTOS, M. O espaço dividido: os dois circuitos da economia urbana dos países subdesenvolvidos. São Paulo: EdUSP, 2004. (Coleção Milton Santos, n. 4).

SCHWARTZ, Y. A comunidade científica ampliada e o regime de produção de saberes. Trabalho \& Educação, Belo Horizonte, n. 7, p. 38-46, jul./dez. 1999.

SCHWARTZ, Y. Trabalho e educação. Presença Pedagógica, Belo Horizonte, v. 7, n. $3^{8, p}$. 5-17, mar./abr. 2001.

SCHWARTZ, Y. Trabalho e gestão: níveis, critérios, instâncias. In:

FIGUEIREDO, M. et al. (Org.) Labirintos do trabalho: interrogações e olhares sobre o trabalho vivo. Rio de Janeiro: DP\&A, 2004.

SCHWARTZ, Y.; DURRIVE, L. (Org.). Trabalho e ergologia: conversas sobre a atividade humana. Niterói, RJ: EdUFF, 2007.

SERPA, A. O espaço público na cidade contemporânea. Salvador: EDUFBA; São Paulo: Contexto, 2007.

SOUZA, E. C. A arte de contar e trocar experiências: reflexões teóricometodológicas sobre história de vida em formação. Educação em Questão, Natal, v. 25, n. 11, p. 22-39, jan./abr. 2006.

SOUZA, M. N. C. A teia da feira: um estudo sobre a feira-livre de São Joaquim, Salvador, Bahia. 2010. 252 f. Dissertação (Mestrado em Ciências Sociais) Faculdade de Filosofia e Ciências Humanas, Universidade Federal da Bahia, Salvador, 2010.

ZARIFIAN, P. Objetivo competência: por uma nova lógica. Tradução de Maria Helena C. V. Trylinski. São Paulo: Atlas, 2001. 


\title{
Os mineiros do amianto da lã do minério à contaminação do mal
}

\author{
CLÁUDIA DE OLIVEIRA D'AREDE \\ MARIA DO CARMO SOARES DE FREITAS \\ MÔNICA ANGELIM GOMES DE LIMA
}

\section{Introdução}

Este estudo descreve a transfiguração social das significações do amianto em uma comunidade de mineiros de Bom Jesus da Serra, Bahia, Brasil, apresentando esse minério como uma configuração do mal para o corpo e o lugar. Ou seja: uma contaminação ambiental e doenças em trabalhadores e suas famílias.

Entra em foco a contaminação do amianto, suas significações, o trabalho na mina, a noção do processo saúde-doença, riscos passados, presentes e futuros decorrentes da exposição a este minério que provoca asbestoses (doenças pulmonares obstrutivas crônicas) e canceres de pulmão, mesoteliomas de pleura e pericárdio.

A relação do homem com o amianto é antiga, pois ele é um facilitador da vida cotidiana, por suas principais características de isolante térmico e resistência às altas temperaturas, bem como, um elemento mágico e etiológico de doenças.

A Organização Mundial da Saúde (OMS) considera o amianto cancerígeno desde 1977 e estima que cerca de 107 mil trabalhadores morrem a cada ano no mundo por doenças causadas por esse minério. Na década de 
1990, a contaminação por amianto se tornou um problema de saúde pública em países da Europa, como a França, por exemplo, onde cerca de 100 mil pessoas poderão morrer de doenças relacionadas ao amianto até 2025 . As estimativas mostram que o câncer causado por amianto poderá matar na Europa Ocidental, aproximadamente 250 mil pessoas entre 1995 e 2029. O primeiro país europeu a banir este mineral foi a Noruega em 1984. Desde 2005, a fibra do amianto está banida em toda a Europa. Atualmente, está proibido em mais de sessenta países. (ABREA, 2010)

O Brasil é o terceiro produtor mundial, o segundo exportador e o quarto usuário de amianto. Produz mais de 250 toneladas por ano, perdendo para Rússia, Cazaquistão, China e Índia, respondendo por cerca de $10 \%$ de toda a produção mundial. A produção do tipo anfibólio, no Brasil, está banida desde 1991 pelo Ministério do Trabalho e Emprego, conforme Anexo 12 da NR15, que regulamentou e Convenção 162 da OIT e depois ratificou com a Lei 9055/95 que trata de coibir definitivamente o uso desse produto. Entretanto, há ainda uma mina de amianto no Brasil, localizada no município de Minaçu, Goiás. Ela produz amianto do tipo crisotila, terceiro maior produtor mundial, suprindo todo o consumo interno, e exporta para dezenas de países. Sua produção atinge aproximadamente 180.000 toneladas/ano. (PAMPLONA, 2003)

Até a década de 1930, o Brasil importava todo o amianto que consumia, principalmente do Canadá e África do Sul. (ABREA, 2010) Em 1939, com a descoberta do minério em São Félix, Bom Jesus da Serra, na época município de Poções, Bahia, dá início à exploração no Brasil. Esta mina, a cinco quilômetros da sede do município, permaneceu ativa até 1967, na época, com 548 trabalhadores. Em 2010, a população do município de Bom Jesus da Serra era de 10.550 (IBGE, 2010) e o Índice de Desenvolvimento Humano Municipal (IDHM) em 0,546, um dos menores da Bahia. Estando esse município, cerca de 120 quilômetros, distante da cidade mais importante do sudoeste baiano; Vitória da Conquista.

Diante do possível adoecimento de contaminação por amianto em mineiros de Bom Jesus da Serra, este estudo apresenta significados desse problema para as pessoas que viveram nesse ambiente da mineração, e abre a discussão sobre o tema da contaminação por amianto, questionando a ausência de políticas de saúde direcionadas a essa região. Para tanto, o estudo dá voz à singularidade da situação da exploração do amianto há mais de 40 anos, suas consequências e repercussões atuais. 
Foi necessário conhecer etnograficamente as mudanças nesta comunidade, onde ruas e casas são pavimentadas e construídas com o amianto; a mina abandonada hoje é lugar de lazer e pesca, mesmo com o processo do adoecimento dos mineiros e de suas famílias pela contaminação ambiental. Sobretudo, tornam-se visíveis as lembranças da “época da mina”, em um tempo e espaço no qual o amianto continua presente em suas vidas.

\section{Metodologia}

Trata-se de uma etnografia sobre os significados do amianto e a saúde dos mineiros de São Félix cujo procedimento metodológico requer o uso de diversas ferramentas, tais como: observação participante, entrevistas em profundidade, registro fotográfico e análise documental. Os roteiros de entrevistas abordaram fragmentos de histórias de vida dos mineiros, modos de viver e noções sobre saúde, processos de trabalho e questões sobre a contaminação pelo amianto.

A intenção desta pesquisa guarda relação com a compreensão do processo de construção da identidade social da comunidade de mineiros em relação ao trabalho no mundo da vida e o amianto. (DUARTE, 1986; LÉVI-STRAUSS, 1989) Assim, o esforço de envolver a experiência do convívio com as histórias dessas pessoas é revelado no trabalho de campo, com os escritos da escuta, das observações do cotidiano e as imagens registradas. Tudo gira em torno do processo de construção de uma identidade narrativa. (RICOEUR, 2009)

Nessa perspectiva, a pesquisa conversa sobre significados do amianto e a saúde para os mineiros e suas famílias, conjugando valores, costumes e práticas, percepções e representações sociais na continuidade e descontinuidade de um tempo vivido na mina ainda presente na memória destes protagonistas. A mina fechada na década de 1960 ainda apresenta resultados físicos da contaminação e subjetivos pelo medo de adoecer.

Semelhante condição foi observada por Eckert (2012) ao estudar a vida dos mineiros do carvão na França, em que se mostram significações de uma cultura repleta de representações e práticas de viver no mundo da mina.

Os mineiros de São Felix e suas famílias narram suas histórias de vida e trajetórias seguindo uma lógica temporal desde o funcionamento da mina ao momento atual, os impactos para o trabalho e a saúde. A experiência entre ser camponês e mineiro e vice-versa. 
Ao mergulhar no mundo desses mineiros e escutar suas vidas recordadas foi imaginável ir e vir no tempo com as longas entrevistas e as observações de campo percebendo seus caminhos narrados neste lugar que representam vida e morte, como se mostrará a seguir.

\section{O lócus etnográfico: a Mina de São Félix}

A exploração na mina de São Félix em Bom Jesus da Serra, Bahia, no período de 1939 a 1967, introduz subsequentes alterações nos modos de vida e costumes da comunidade: homens e mulheres transitaram das atividades tradicionais de agricultura de subsistência à extração do minério.

Com a mineração, vários mineiros buscaram se especializar na atividade de marteleteiro, quebrando pedra com o martelo no pilão para extração do minério, antes da chegada das máquinas de britagem, sendo essa uma das principais funções dos mineiros na época.

O ato da extração e exploração da terra, comum a todos os que se relacionam com ela, e a conscientização da contaminação, consequente ao ato de lidar com o amianto, aparecem como contradição da natureza.

O que "faz mal" é como um corpo simbólico presente na comunidade de Bom Jesus da Serra, que tem raízes em um imaginário coletivo do mundo da vida revelado como estranhamento da natureza.

O risco invisível do amianto para o corpo é como uma ameaça inevitável e recente. Em trinta anos de mineração, muitos trabalharam, adoeceram e morreram sem vincular a contaminação do minério ao adoecimento.

O minério tem lugar natural, mas a coexistência com o mundo dos homens agrega a falta de assistência e de informação e mantém a presença da empresa nas relações de poder e controle da saúde dos mineiros. Para estes, o perigo estava na usina de beneficiamento do amianto, da qual vinha a poeira branca que tudo cobria.

Poeira branca é o amianto propriamente, que contamina o corpo e o ambiente - plantações, animais, água e ar. A contaminação se revela no adoecimento, como sentido de perigo ameaçador. $\mathrm{O}$ risco acontece quando aparecem os sintomas, adoecimento e morte. Os sintomas referidos são: falta de ar, tosse, cansaço e mal-estar. A contaminação no corpo está no sentir-se sem forças pelo "mal do minério". As mortes dos parentes e amigos atribuídas ao amianto preenchiam o cotidiano do trabalho na mina e integravam 
o sentido de estranhamento com a tosse que os faziam cuspir lama. Ainda assim, ficavam sem proteção de serviços de saúde e a empresa os desinformava ao afirmar que "aquilo" - $o$ amianto - não fazia mal.

Na dimensão subjetiva, o amianto em Bom Jesus da Serra aparece nas falas dos mineiros de duas maneiras: como um agente natural e um mal. A montanha se transforma em mina que produz um pó branco que adoece $\mathrm{o}$ trabalhador e sua família. Entretanto, conforme suas narrativas, ninguém enxergava o mal, até surgir os primeiros casos de asbestose e câncer.

Antes, "o amianto não maltratava ninguém", até ser modificado pelo homem. Atualmente, após tantos anos do fechamento da mina, o lugar foi reinventado e incorporado à vida com atividades de lazer e história, ao lado do sofrimento, doenças, perigo e morte que ainda persistem. Pois, pessoas continuam morrendo de doenças associadas ao amianto.

Com o encerramento da mina, os mineiros voltaram a trabalhar apenas na roça, como seus antepassados. A pobreza é generalizada. Muitos estão aposentados como trabalhadores rurais, e sustentam a família inteira, filhos e netos, principalmente pela falta de geração de emprego na região. Complementam a alimentação - feijão, milho e mandioca - com o pouco que produzem nas roças e tantas vezes comem frutas - umbu, melancia - verdes, pois na necessidade de algo para comer não dá tempo para esperar que amadureçam. É situação de escassez de muitas necessidades básicas.

[...] Tinha roça, mesmo trabalhando na mina. Na semana que trabalhava de noite na mina, no correr do dia eu estava na roça. Se não fosse a lavoura, a gente sofreria mais. Quando a mineradora saiu daqui eu disse: 'não vou pra Goiás porque tenho minha família aqui, trabalho aqui, tenho a minha terra aqui, não vou'. (Aureliano)

[...] Hoje em dia, tem mês de comprar feijão, açúcar, café, óleo que não pode faltar. Mas nesse mês, nem o feijão, nem o arroz pude comprar. E a roça não está dando nada. Aí a gente pega uns pedacinho de carne, ou de fato, o que for, frita, fazfarofa e come. (Ilda)

A roça é a única perspectiva dessas pessoas conhecedoras dos ciclos naturais de chuvas e plantio, qualidade da terra. A atividade de mineiro foi aprendida paralelamente à atividade rural, representando um ofício a mais, entretanto para muitos não foi o principal ofício. Nesse sentido, a condição de camponês permanece. 
Este aspecto faz recordar a obra de Lévi-Strauss, $O$ pensamento selvagem (1989), sobre as sociedades tradicionais que veem a terra como um bem da natureza. $\mathrm{O}$ camponês não é o dono da terra, mas a utiliza para o plantio. Nesse aspecto, a mudança de clima é relacionada ao sagrado e o surgimento do "homem sabido" faz relação com o destruidor. O que chegou de fora e implantou a mineradora trazendo doenças, perigo e morte. Destruiu a quietude do lugar e mudou o tempo.

Os camponeses-mineiros entendem que ao modificar a natureza, a mineradora se apoderou do amianto, que antes não fazia mal, e passou a atingir o homem e o clima, afetando a roça.

Os mineiros trabalharam dentro e fora da montanha, permitindo-lhes um conhecimento para além da condição de agricultores. Com isso, percebem, relatam e interpretam o mundo do trabalho com símbolos e significados próprios e socialmente compartilhados. $\mathrm{O}$ amianto estava intacto dentro da montanha e foi mexido, trazendo o mal para a vida do lugar.

Como parte da vida, sentem-se camponeses e mineiros, sem separação. Seguem hoje como camponeses, mesmo aposentados, e recorrem às lembranças da mina, do trabalho com os vagões, o "marrão" (martelo), a "cama de poeira” (câmara de poeira) e a retirada da lã do minério das pedras. São homens e mulheres do campo que não conseguiram, a partir do trabalho na mina, qualquer resultado prático dos direitos trabalhistas contemplados nesta atividade.

[...] Na usina, eu trabalhava na água, de meio dia pra tarde, ia pro fundo da usina pra pegar a produção do vagão, pra entregar no escritório. Quando o vagão de minério saía, passava ali, pesava o de rejeito,jogava pra cá aquela banca que tinha cá. No outro dia, eram outros, de manhã até meio dia, depois outros vinham pra botar água de meio dia pra tarde, era assim. Até que chegou a um ponto que eu fui pro corte, depois mejogaram pra pedreira, levando minério pro galpão pra quando chovesse a usina não parasse, pra ter minério seco, outra hora trabalhava no minério, furando pedra. E aí ninguém levou a sério isso. Deixou prejudicar demais, alguns tinham febre, uns morriam, chegavam a amarelar. (Antônio, mineiro)

\section{O mal do minério: "a placa pleural"}

Antes mesmo de analisar as narrativas dos mineiros de São Felix, vale recordar alguns autores e noções sobre o processo interpretativo do adoecimento. Para Alves (2006) a doença é um fenômeno que diz respeito a um conjunto de 
elementos socioculturais interligados; sickness refere-se ao mundo da doença, isso é, um horizonte de significados, condutas e instituições associadas à enfermidade ou ao sofrimento.

Para B. Good e M. Good (1980) a enfermidade é também uma construção social a partir das teorias e redes de significados que compõem as diferentes subculturas. Nesse sentido, a enfermidade é essencialmente semântica e a transformação da doença em experiência humana é objeto do sentido. Assim, a enfermidade é uma experiência dotada de sentido para cada sujeito particular. A ideia de enfermidade como "rede semântica", realidade construída através do processo de interpretação/significação, se fundamenta na rede de significados que estrutura a própria cultura. São estruturas profundas que ligam enfermidades a valores culturais fundamentais de uma cultura, permanecendo, ao mesmo tempo, fora do conhecimento cultural explícito e da consciência dos membros que compõem a sociedade, apresentando-se como naturais. (GOOD, 1994, p. 172)

A partir destes conceitos, tenta-se entender a realidade sobre a relação do homem com o amianto, seus significados, e conhecer a noção do processo saúde/doença, riscos passados, presentes e futuros decorrentes da exposição a esse minério.

Para os mineiros, seus sintomas de adoecimento não eram e ainda nem sempre são considerados pelo serviço de saúde da empresa. Para os mineiros, a doença é interpretada através da simbologia: "um mal dentro do corpo com uma fôrma"; o minério guardado no corpo, em algum momento, pode se manifestar. A ameaça do adoecimento é percebida através do ar, o condutor do amianto no corpo. $\mathrm{O}$ lugar em que nasceu, e vive atualmente, passa a ter um sentido ameaçador e convive-se com esta ameaça, o risco. Passam a conviver com o estigma social do lugar, como se vivessem em perigo permanente para asbestose e câncer de pulmão. Doenças que se manifestam muitos anos depois do contato, e o risco ambiental continua com a poeira do amianto.

Os padrões culturais que as pessoas utilizam para interpretar um dado episódio de doença são criações sociais, interpretações construídas intersubjetivamente. Só dentro das coordenadas estabelecidas pelo mundo intersubjetivo do senso comum é que a experiência da enfermidade é admitida como fato evidente. (SCHUTZ, 1979) A enfermidade, subjetivamente dotada de sentido, é afirmada como real para os membros da sociedade e entendida como experiência individual e coletiva simultaneamente. 
[...] Tenho minério guardado no corpo, quando vai aparecer esse mal que está guardado, a gente não sabe. (Deco, mineiro)

A gente está respirando o pó. Aié difícil. Às vezes, eu penso muito em sair daqui, mas qual é a condição que eu tenho de sair daqui? (Damião, mineiro)

[...] Esse pó é tão forte, que quando a pessoa gripava, era ofedor do pó, era aquele mau cheiro de pó, ninguém aguentava o cheiro. Ele tinha um cheiro forte diferente, parecido com água sanitária. (D. Bina)

Antigamente, era mais pó do que terra que forrava essas estradas. (Seu Alberto)

De dez da noite às seis da manhã, poeira, poeira, poeira! A gente não pensava. Era normal. Quando a gente escarrava, só saía a poeira. De lá tacava nas peneiras, e a poeira subia direto. Era muita gente, muita gente cuspindo sangue com poeira, tossindo. (Clemente, mineiro)

Para os mineiros de Bom Jesus da Serra, a experiência comum revela na linguagem o vento como o condutor da ameaça da contaminação de amianto que produz enfermidades. A sensação de se sentir mal se encontra intrinsecamente acompanhada de uma compreensão do seu significado: o pó do amianto que adoece e mata.

Está em jogo as forças da natureza como o vento e a pouca chuva no lugar semiárido que espalha o "pó que faz mal”. Assim, os modos interpretativos sobre o aparecimento das doenças relacionadas ao amianto, submetem-se às estruturas de pensar o trabalho, a natureza, a sobrevivência, a tradição dos familiares.

Alves (1993, p. 269) relata que uma enfermidade se constitui como uma interpretação, um julgamento cujo componente subjetivo “[...] está fundamentado no ato individual de perceber a experiência interior como problemática, [mas] a construção [...] desta experiência não ocorre como um processo isolado”.

Conforme a narrativa dos mineiros de São Felix a doença,

Começa pelos lábios. Vai ficando com os lábios secos, não saliva mais, vai ficando com os pulmões. Porque a gente tem esse processo de inspirar, encher os pulmões. O portador de asbestose não consegue fazer isso; então ele morre asfixiado, praticamente asfixiado, por não conseguir respirar, é horrível! [...] Meu pai falava da dificuldade pra respirar. Ele andava 50 metros, 10, 15 minutos, descansava, depois andava mais um pouquinho e sentava. Porque, 
mesmo doente, ele tentava andar. E minha mãe morreu antes, com os mesmos sintomas, cansaço, que nem o meu pai. (Osvaldo, mineiro)

[...] O que mudou na minha vida foi perder a minha saúde. Eu sinto uma falta de ar, um 'avexamento' assim por dentro, e depois que eu fiz esse exame o médico disse que eu estava com inflamação no intestino, eu sinto uma dor aqui debaixo da costela, não durmo bem, já perdi cinco quilos. (Aureliano, mineiro)

Ter perdido a saúde por causa do trabalho na mina e a impossibilidade de se dedicar mais às atividades na roça constituem em impactos da enfermidade na vida dessas pessoas em todas as suas dimensões.

A placa pleural é uma atribuição médica incorporada à cultura local, uma doença não explicada. Algo que poderá crescer ou não, mas que dá visibilidade à presença da contaminação no corpo. Uma placa dentro do corpo, visível ao exame médico e presente também em outros, concretiza a ameaça, mas também a semelhança entre os mineiros da mina de São Félix:

Eu sinto uma dor do lado, parece que o minério está pregado, eles disseram que é a placa do minério que entrou e ficou, e eu estou sentindo agora. Tenho que fazer exame pra ver a placa pleural. E o meu irmão João disse que também tem. (Alberto, mineiro)

[...] Sinto um cansaço, uma tristeza. Eu trabalhei muito tempo naquela mina pras 'madames' que vinham da França. Tive um entupimento no nariz, pela lã (ou pó) do amianto que entra na gente, é doença do homem. (Vitória, viúva de ex-mineiro)

O mal do minério possui significado de placa pleural, termo absorvido por eles, como uma doença que entra no corpo através da lã ou fibra, pó ou poeira, deixado pela empresa no passivo ambiental da mina abandonada. Os mineiros do amianto buscam tratamento nos serviços de saúde locais e outros alternativos. Inicialmente, quando apareceram os sintomas de abestose, como cansaço, tristeza e tosse, os trabalhadores e suas famílias passaram a fazer tratamentos caseiros, indicados por “métodos encantados” $\mathrm{e}$ com a fé no sagrado. Usavam e ainda usam ervas como sabugueiro, urso etc.

Também, algumas mulheres adoeceram, pois lavavam as roupas dos maridos e sentiam a presença do amianto no corpo. Para elas, a placa pleural é a doença da contaminação do minério no corpo. Uma placa dentro do corpo, visível ao exame médico é uma ameaça concreta semelhante entre os mineiros da mina de São Félix. 
As doenças mais comuns causadas pela fibra mineral são as doenças do pulmão, asbestose - conhecida como "pulmão de pedra", na qual o doente é lentamente levado à morte por asfixia - e o mesotelioma - um tumor maligno, agressivo e letal na maioria dos casos, conhecido como o "câncer do amianto". Como um agente potencialmente cancerígeno a fibra do amianto presente no pulmão configura-se como uma ameaça permanente para $\mathrm{o}$ adoecimento e a morte.

\section{Conclusão}

[...] Eu acho que todos que entram naquela área, que moram no entorno da mina, estão correndo um grande risco de serem contaminados. Se num momento a gente inala uma fibra o câncer está garantido. Não tem como controlar. Porque nada destrói o amianto. Se você pegar uma fibra de amianto e levar ao fogo, ela fica em brasa e aí volta ao estado normal. É como se nada tivesse acontecido; então, qual o medicamento pra destruir um trem desse? Então, eu acredito que tem muita gente contaminada aqui na região e que se não tirar esse amianto aí rapidinho, ele vai contaminar muita gente. (Representante local da Associação Baiana dos Expostos ao Amianto - ABEA)

A exploração na mina de São Félix em Bom Jesus da Serra, Bahia, no período de 1939 a 1967, induziu subsequentes alterações nos modos de vida da comunidade: homens e mulheres que transitaram das atividades tradicionais de agricultura de subsistência à extração do minério.

O risco invisível de adoecimento associado ao minério coexiste há 70 anos com a falta de assistência à saúde e de informações sobre o controle da saúde dos mineiros.

A convivência com o amianto, ou a 'pedra cabeluda' como a nomeiam, é para alguns, naturalizada como um objeto comum do lugar, e para outros uma ameaça à vida. Para alguns o perigo estava na usina de beneficiamento do amianto, de onde vinha a lã ou poeira branca que tudo cobria. E a contaminação se revela apenas no adoecimento. Antes, sem sintomas nada parecia ameaçar. Ao surgirem os primeiros casos, os mineiros aprendem a associar o amianto às doenças e óbitos dos companheiros da mineração.

Ainda sentem "uma coisa estranha", "uma tosse”, e relembram o trabalho sem proteção alguma e a mensagem enganosa da empresa. Ao encobrir a 
informação sobre o dano à saúde e manter a exploração da mina, a empresa SAMA se torna responsável pelo crime ambiental.

Segundo Beck (2010), o risco é invisível na modernidade. Atualmente, o risco invisível do amianto está presente nos discursos dos filhos dos mineiros ao se recordarem e dos netos que ainda brincam com as pedras do minério.

Apesar desse quadro de morbidades gravíssimas: asbestoses - doenças pulmonar obstrutivas crônicas - e canceres de pulmão, mesoteliomas de pleura e pericárdio empresa e Estado os abandonaram. O movimento social dos mineiros, Associação Baiana dos Expostos ao Amianto (ABEA), denuncia permanentemente a situação desses mineiros e de suas famílias e tenta resgatar os direitos previdenciários das vítimas.

A ABEA funciona como único movimento contrário à SAMA na busca por indenizações e planos de saúde para todos os mineiros e tem ao longo do tempo encontrado embates com o poder judiciário. Uma ação civil pública movida pelo Ministério Público Estadual e Federal, através da ABEA e Associação Brasileira de Expostos ao Amianto (ABREA) em 2008, cuja medida visa dar cumprimento à determinação da justiça federal de Vitória da Conquista obrigou o Estado, os municípios e a empresa SAMA a cumprirem algumas obrigações, como por exemplo: o cadastramento dos trabalhadores e familiares pela exposição ocupacional e ambiental, e a composição de junta médica pela Secretaria de Saúde do Estado da Bahia para realização de exames de saúde dos trabalhadores. Outra ação civil pública ambiental ainda está em curso para obrigar a referida empresa a reparar danos ambientais.

\section{Referências}

ASSOCIAÇÃO BRASILEIRA DE EXPOSTOS AO AMIANTO - ABREA. História do Amianto. Osasco, 2010. Disponível em: <http://www.abrea.org.br/o-amianto/ hist\% 3 \%B3ria-do-amianto.html>. Acesso em: 22 abr. 2010.

ALVES. P. C. A experiência da enfermidade: considerações teóricas. Cadernos de Saúde Pública, Rio de Janeiro, v. 9, n. 3, p. 263-271. jul./set. 1993.

ALVES. P. C. A fenomenologia e as abordagens sistêmicas nos estudos sócioantropológicos da doença: breve revisão crítica. Cadernos de Saúde Pública, Rio de Janeiro, v. 22, n. 8, p. 1547-1554, ago. 2006.

BECK, H. Sociedade de risco: rumo a uma outra modernidade. São Paulo: Ed. 34, 2010. 
DUARTE, L. F. D. Da vida nervosa: nas classes trabalhadoras urbanas. Rio de Janeiro: Zahar; Brasília: CNPq, 1986.

ECKERT, C. Memória e trabalho: etnografia da duração de uma comunidade de mineiros de carvão (La Grand-Combe, França). Curitiba: Appris, 2012. (Ciências sociais).

IBGE. Censo Demográfico 2010. Rio de Janeiro, 2010.

GOOD, B. Medicine, rationality, and experience: an anthropological perspective. Cambridge: Cambridge University Press, 1994.

GOOD, B.; GOOD, M. J. D. The meaning of symptoms: a cultural hermeneutic model for clinical practice. In: EINSERBERG, L.; KLEINMAN, A. (Ed.). The relevance of social science for medicine. Boston: D. Reidel Publishing Company, 1980.

LÉVI-STRAUS, C. O pensamento selvagem. Campinas, SP: Papirus, 1989.

PAMPLONA, R. I. O amianto crisotila e a SAMA: 40 anos de história Minaçu-Goiás: da descoberta à tecnologia limpa: 1962-2002. Minaçu, 2003.

RICOEUR, P. Teoria da interpretação: o discurso e o excesso de significação. Lisboa: Edições 70, 2009. (Biblioteca de filosofia contemporânea, n. 2).

SCHUTZ, A. Ação no mundo da vida. In: WAGNER, H. R. (Org.). Fenomenologia e relações sociais: textos escolhidos de Alfred Schutz. Rio de Janeiro: Zahar, 1979. p. 120-140. 


\section{"Marés de dor" \\ as mediações do corpo no cotidiano das marisqueiras}

THAIS MARA DIAS GOMES

SÉRGIOTRAD

MÔNICA ANGELIM GOMES DE LIMA

\section{Introdução}

Nas últimas décadas, a crise do modelo científico da biomedicina vem contribuindo para uma maior inserção e valorização das ciências sociais no campo da saúde. Nos países em desenvolvimento, como o Brasil, as ciências sociais têm contribuído para a compreensão e enfrentamento das situações de desigualdade social, assim como, na incorporação e análise de dimensões subjetivas e simbólicas que permeiam a relação saúde/doença/cuidado.

Interessa aqui destacar particularmente as contribuições em torno da categoria corpo. Na perspectiva socioantropológica de corpo, prevalece a compreensão da corporeidade humana como fenômeno social e cultural, motivo simbólico, objeto de representações e imaginário. (LE BRETON, 2007) Mais especificamente, este trabalho, focaliza a interface corpo-trabalho. O corpo aqui se apresenta como o "vetor semântico" na relação com o mundo do trabalho, contemplando

atividades perceptivas, mas também expressão dos sentimentos, cerimoniais dos ritos de interação, conjunto de gestos e 
mímicas, produção da aparência, jogos sutis da sedução, técnicas do corpo, exercícios físicos, relação com a dor, com o sofrimento, etc. (LE BRETON, 2007, p. 7)

De acordo com Luc Boltanski (2004), as preocupações relacionadas ao corpo variam entre as camadas sociais, sendo a atenção prestada ao corpo nas classes populares menos frequentes. Particularmente neste grupo, o uso do corpo pode compreender uma visão mais utilitária, fruto da importância da força física nas ocupações desempenhadas. No cotidiano da sobrevivência diária sobressaem duras e longas jornadas de trabalho, incluindo os afazeres domésticos e os cuidados com os filhos. Neste contexto, na produção de significados sobre o corpo, tende a prevalecer sua funcionalidade a serviço da sobrevivência material.

As mulheres desse estudo permeiam o universo da pesca artesanal de mariscos, que, a despeito de se revelar uma atividade eminentemente feminina, transitam quase invisibilizadas. São reconhecidas como marisqueiras e exercem uma atividade que envolve tradições, tecidas geração após geração, desvendando os caminhos da arte de ser marisqueira. Detentoras de um vasto arsenal de saberes marítimos, elas criam e recriam um modo de ser no mundo, através do habitus de vida (BOURDIEU, 1989) que tece a teia de significação do corpo-que-trabalha-na-maré.

Aproximando-se da fenomenologia do corpo, da perspectiva de estar-no-mundo e ser lançado a um projeto por inteiro, Merleau-Ponty (1999, p. 205) adverte que o corpo está "atado a um certo mundo, nosso corpo não está primeiramente no espaço: ele é no espaço”. Percebem-se em cada indivíduo, marcas originadas de experiências vivenciadas ao longo da vida. Tais experiências formam um todo que caracteriza o ser em sua totalidade: um corpo que sente e ao mesmo tempo é sentido. Não sendo apenas um objeto no mundo, o corpo é sensível e perceptível.

É preciso ademais reconhecer o corpo enquanto elemento de mediações de práticas e considerar estas no bojo da dialética estrutura-agência. Impõe-se, nesta relação, nos termos de Bourdieu (1989, p. 58), uma dinâmica que revela certa "harmonia entre o senso prático e o significado objetificado". Um olhar sensível à prática da mariscagem no universo de mulheres de classes populares irá confirmar dita tendência.

Marcel Mauss (1974), por sua vez, analisa os gestos e os movimentos corporais como técnicas próprias da cultura, e, portanto, possíveis de trans- 
missão com seus significados específicos através das gerações. O corpo é assim descrito como um texto, revelando marcas, mitos, símbolos, gestos, movimentos, traços sociais e significação cultural. (LE BRETON, 2003)

Na questão da dor, manifesta-se claramente a relação entre o indivíduo e a sociedade. $\mathrm{O}$ aprendizado da dor se inicia na unidade familiar e se modifica, se integra e se mantém com a ampliação da convivência social, sendo o processo de socialização essencial ao desenvolvimento de crenças, valores e atitudes relativos à dor. (PIMENTA; PORTNOI, 1999) O fenômeno da dor está situado, portanto, em um escopo bem mais amplo e necessita ser apreendido a partir de uma visão multidimensional.

Este capítulo discutirá sentidos e práticas mediadas pelo corpo no cotidiano da mariscagem a partir da análise de dados produzidos em pesquisa etnográfica, orientada pela perspectiva fenomenológico-compreensiva, realizada em uma comunidade pesqueira do município de São Francisco do Conde, Bahia.

Foram realizadas seis entrevistas em profundidade, além da observação participante que aconteceu entre janeiro de 2011 e janeiro de 2012. A produção de dados articulou narrativas de mulheres que vivem do trabalho da mariscagem e dados produzidos na observação participante do cotidiano da ilha, registrados em diário de campo. A etnografia focalizou as seguintes dimensões: trabalho na maré, ambiente doméstico, espaços religiosos e de lazer, análise do trabalho e análise documental. No escopo do presente texto, privilegiou-se a discussão de duas dimensões exploradas na pesquisa: os rituais do corpo ou habitus, mobilizados nos diferentes momentos que se sucedem no cotidiano da mariscagem; dor associada ao trabalho com mariscos, seus significados e itinerários terapêuticos.

\section{O corpo em movimento no cotidiano da mariscagem: os rituais}

Ao resgatar os diferentes momentos e processos a que integram o trabalho cotidiano na maré, importa aqui discutir como o corpo é evocado e mobilizado em cada caso. Veremos a seguir, um conjunto de rituais e práticas que envolvem ditos processos, que vão desde a preparação do corpo para fazer frente à jornada de trabalho, aos vários procedimentos envolvidos na coleta ou na mariscagem propriamente dita, chegando ao momento da venda do marisco. 
De imediato, observa-se que o sentido corrente de corpo "frágil” da mulher perde significado, cedendo espaço para o trabalho manual/braçal realizado na maré. Esse corpo forte no trabalho é comparado ao corpo do homem, capaz de realizar "atividades de homem”. A marisqueira se veste para o trabalho utilizando os recursos que lhes são disponíveis para amenizar os riscos a que o corpo é exposto, definindo o abastecimento, nem sempre o necessário para a manutenção da jornada na maré, como revela Tatiana, jovem com 27 anos: "Já cansei de ir para o mangue sem tomar café da manhã, ficava até tarde. Quando tem, a gente leva, quando não tem, a fome aparece e morre no corpo, às vezes quando a gente chega em casa já não tá mais com fome”.

O corpo também confecciona e improvisa os instrumentos de trabalho da mariscagem. A realização do trabalho é realizada por instrumentos de baixo ou nenhum custo como uma colher ou faca para retirada do marisco e um balde para o transporte.

O lugar principal da mariscagem, a coroa, fica a aproximadamente um quilometro da vila. Passando por dentro da mata, guiado por um estreito caminho de chão batido. $\mathrm{O}$ corpo, muitas vezes descoberto, está sujeito a pequenos ferimentos de galhos ou insetos, ou mesmo a um pernoite ao relento. Como narra uma das marisqueiras: "Eu já sai daqui pra ir pra lá remando, 10 horas de remo, e eles na canoa (os filhos). Já cheguei até a dormir lá, pois não tinha condições de voltar com o vento e mar na cara. (Mônica, 40 anos)

\section{A coleta - a mariscagem propriamente dita}

O corpo aprende silenciosamente os gestos, a utilização de forças, as estratégias de trabalho, o melhor local para retirada do marisco. Aprende a lidar com os ciclos da mulher - menstruação, gravidez, amamentação - e o trabalho na maré. Surgem mitos impressos no corpo da mulher, o útero que interioriza a lama do mangue como me explica Tatiana:

Diz que, no mangue, a mulher não pode mariscar porque a mulher tem útero, $e$ para mariscar no mangue é mais arriscado que o homem, minha mãe contava de uma moça que morreu e no exame transvaginal o médico viu o útero dela cheio de lama de mangue, ela mariscava abaixada, o vapor do salitre às vezes caia no buraco, a lama introduzia e entrava, passava às vezes com lama na cintura, ela terminou se prejudicando. (Tatiana, 27 anos) 
Durante a coleta, observam-se rápidos e precisos movimentos com as mãos, que chegam a uma frequência média de 9.800 movimentos repetitivos por hora na extração de "chumbinho". Números que são próximos ao de outras regiões de mariscagem, com 10.200 movimentos/hora. (PENA; FREITAS; CARDIM, 2011)

Com o corpo envergado para frente, e segurando uma colher, realiza movimentos rápidos com as mãos, as informações tátil, auditiva e visual informam a presença do marisco. Enquanto uma mão cava em busca do marisco a outra armazena até enchê-la e em seguida depositar no balde. (Diário de campo, janeiro de 2011)

Nos locais de mangue o corpo assume outras posturas, pois o ambiente exige mais dele, exige equilíbrio e agilidade para não cair ou atolar:"Uma vez atolada só com a ajuda de alguém para nos tirar do buraco que nosso corpo desenhou na lama". O risco de afogamento na lama revela os perigos do mangue e a preferência pelo trabalho na costa, "coroa”. Solange me fala sobre as vestimentas, os esforços, a habilidade do corpo na lama e compara o trabalho no mangue e na coroa:

Veste calça, o sapato, puxa lama, a lama vem até aqui (aponta a cintura), o único lugar melhor de mariscar é na coroa! Lá é tudo laje, a gente marisca abaixada, mas ali não tem muita lama, mas no mangue se vocêfor, ai, ai, ai, a lama éfunda, tem um rio aqui, Rio da Ceara. (Solange, 56 anos)

A consciência de que um sujeito tem do corpo é expressa como um esquema corporal, percebido através da posição adotada pelo corpo e sua inter-relação com o meio ao que pertence. Os diferentes domínios sensoriais - visuais, táteis, sinestésicos, outros - que são de interesse para a percepção do corpo, não se oferecem como regiões estranhas umas às outras, mas se apresentam interligadas, formando um sistema. (MERLEAU-PONTY, 1999)

Ao avançar da maré, avança-se com os instrumentos de trabalho. Ao final da coleta lava-se o marisco na água do mar para retirada do excesso de areia, uma estratégia para reduzir o peso carregado durante o percurso de retorno da maré. O mesmo trajeto é percorrido, porém, com o sobrepeso do marisco que pode variar entre 20 ou 40 quilos, a depender da maré. 


\section{Chegar em casa e cozinhar o marisco}

Vera arruma o marisco em uma panela para fervê-lo no fogo a lenha. Para que a panela não fique muito cheia e o marisco cozinhe direito, ela divide em partes menores. Depois de cozido, carrega a panela com o corpo envergado, com o peso nos braços para depositá-los na bacia da cata. O fogão a lenha fica em uma área coberta nos fundos da casa, a fumaça invade os poucos cômodos existentes. Uma fumaça ${ }^{1}$ que invade não só a casa, mas o corpo, após a inalação a tosse não demora a aparecer. Os olhos ardem, o nariz irrita, mas com o passar do tempo o corpo parece se acostumar, como observa Vera:

É tosse, por causa da fumaça, fico assim. Tenho que preparar ofogo, eu boto é na lenha, não é no fogão não. Meu gás foi minha 'fia' que inteirou de dia das mães, acabando não vai ter dinheiro tão cedo para comprar, tem que ser na lenha. A fumaça entra nos olhos, aquela fumaçada, os olhos ardem. Depois passa. (Vera, 6o anos)

O momento do cozimento e da cata ocorre quase que simultaneamente. Inalar fumaça, carregar a panela e despejar na bacia, perduram até o último marisco catado. Para Vera, o rito começa com a "TV ligada, desde 3 horas da manhã ela tá ligada, né”. Seu corpo também está ligado ao trabalho, que se estende ao ambiente doméstico ainda da madrugada, principalmente quando há uma demanda grande de mariscos a serem catados. Após um café ela prepara o forno a lenha e segue com o cozimento e a cata do marisco.

A jornada acontece com frequência, Vera marisca todos os dias. Pela sua agilidade, sempre extrai uma quantidade considerável de mariscos. Sua casa é uma continuidade do processo de trabalho da mariscagem, na casa estão as ostras, o sururu e também vestígios da lama do mangue. Causa espanto que após a jornada na maré ainda tenha forças no corpo para resistir a essa etapa, que também envolve repetição de movimentos, posturas do corpo já cansado que busca relaxar.

Todos os processos da ostra pareciam ser difíceis, sua coleta, seu transporte, seu cozimento e sua cata. Uma jornada que durou aproximadamente três

Segundo Maria Moreira e colaboradores (2008), a exposição à fumaça de lenha são compatíveis com o aparecimento de sintomas respiratórios e alterações da função pulmonar, com riscos de desenvolvimento de DPOC 
horas e meia. Ao final da cata, o marisco é ensacado e armazenado na geladeira, aos poucos vão aparecendo os quilos que serão vendidos em Candeias.

Rodeada pelos mariscos, a vida parece não ser guiada pela lógica do tempo do trabalho. O trabalho termina quando a última ostra é aberta. Nesse cenário, Vera explica sua agilidade e jornada de trabalho:

Eu cato ostra ligeiro, catei um bocado de ostra, eu comecei duas, três horas, acordei cedo e tô aqui, a bichinha dá trabalhado para catar. É vapt-vupt, só cato assim, um dia eu catei uma ruma de ostra assim ô, na casa de minha filha, de tanto eu catei. Já está acostumada a catar ostra não é?! Já estou acostumada a catar, todo dia, só paro quando terminar aqui. De noite eu não cato não, por causa das vista, de dia eu cato, mas de noite não. (Vera, 60 anos)

Seu conhecimento prático refere-se a um dos domínios das técnicas corporais, resultando de sua competência profissional, de um conjunto de gestos de base, e um grande número de movimentos coordenados, nos quais se cristaliza, com o passar dos anos, sua experiência. As técnicas corporais apreendidas ao longo da vida evidenciam um habitus cultural, que, segundo Le Breton (2007), é fruto de um condicionamento social apreendido de maneira informal entre a percepção sensorial sentida pelo outro e esse sistema de referência novo para mim - "a percepção dos inúmeros estímulos que o corpo consegue recolher a cada instante é função do pertencimento social do ator e de seu modo particular de inserção no sistema cultural”. (LE BRETON, 2007, p. 56)

\section{A dor e suas interpretações}

“O cansaço que eu falo é o cansaço da maré: quando todo o corpo dói”

De acordo com Kleinman (1978), o modelo explanatório é construído por noções elaboradas a partir da experiência de doença e em referência aos tratamentos utilizados, distinguindo-se o modelo dos profissionais e os que são utilizados pelo doente e seus familiares. Embora se reconheça que existem críticas quanto a seus limites na abordagem das práticas curativas e a sua perspectiva de saúde, como a ausência de enfermidade, (YOUNG, 1982) seu conceito é utilizado neste estudo para compreender os significados da dor no corpo-que-trabalha-na-maré. 
Cada atividade laboral impõe diferentes demandas ao corpo do trabalhador, com diferentes respostas desde o cansaço (fadiga) à dor muscular aguda ou crônica. No estudo apresentado, a percepção da doença é possibilitada por sinais e sensações corporais como cansaço e fraqueza, indicando que algo impede o funcionamento "normal" do corpo.

A existência de movimentos repetitivos e das posturas adotadas no trabalho da maré são alguns dos fatores que contribuem para a fadiga corporal associada ao ofício de mariscagem. (PENA; FREITAS; CARDIM, 2011)

A maré impõe ao corpo uma continuidade de etapas, longa jornada, carregamento de peso, posturas, gestos, movimentos repetitivos. Ao narrarem o 'cansaço da maré', Solange e Mônica revelam seu aparecimento principalmente após as etapas desenvolvidas fora do ambiente doméstico, um cansaço que cessa com o repouso, mas muitas vezes impede a continuidade do trabalho:

A manhã toda na maré. Quando chega, chega cansada. O cansaço que eu faloé o cansaço da maré. Os braços cansados de remar porque a canoa é de madeira, não tem canoa de motor não. As pernas cansadas de puxar lama. Cansaço é assim, aquele esmorecimento nas pernas, depois vai passando. (Solange, 56 anos)

Cansaço, a gente vai para maré, chega lá a gente solta na lama para tirar ostra, vai carregar balde de ostra pesado para colocar na canoa, quando chega em casa tá arrebentado. Quando chega tem que descarregar a canoa, trazer para casa, tudo é peso, aí a gente sente cansaço, tem dias que nem aguento fazer muita coisa. (Mônica, 40 anos)

O cansaço é expresso no corpo, pois mesmo à noite, enquanto “[...] os demais operários, cansados do labor diurno, metem-se na cama para passar comodamente à noite, num sono reparador, as noites dos pescadores estão cheias de trabalho e insônias". (RAMAZZINI, 1985, p. 213)

Essa forma de perceber a doença expressa bem à importância social do corpo como meio de existência para aqueles que dele dependem para sobreviver. Não somente uma parte do corpo dói, este corpo dói por inteiro, é o "cansaço da maré”, percebido como físico, mas também mental. Segundo Diegues (1983), o trabalho exige o reconhecimento e identificação dos mariscos, além de um vasto conhecimento de espécies, fluxos da maré, estratégias de trabalho em um ambiente em constante modificação. Vera nos 
explica alguns dos conhecimentos necessários para a cata da ostra, demonstrando a exigência não só física, mas um vasto conhecimento no processo de trabalho das marisqueiras e que é necessário estar com a "cabeça boa” para aprendê-lo, “Tem que está com a cabeça boa para aprender isso aqui. A gente tira ostra, a gente sabe que é na 'sapata' que fica, ai bate e tira. Se bater o machado, quebra, corta e vem inteiro". (Vera, 60 anos)

O cansaço também é observado nos relatos de uma respiração cansada pela inalação da fumaça durante o cozimento do marisco, "Eu estava cansando, tive que tomar nebulização, mas a médica disse que era da fumaça do fogo que eu cozinho o marisco". (Jacqueline, 34 anos) Uma fumaça que também “entra nos olhos e ardem", como expressa Mônica em sua narrativa:

A fumaça entra nos olhos, aquela fumaça toda, os olhos ardem, depois passa. Meu pai hoje tá com catarata, tá precisando fazer a cirurgia, praticamente ficando cego, é assim, devido o problema mesmo de maré. Quentura que a gente recebe muito nas vistas para cozinhar o marisco. (Mônica, 40 anos)

A fumaça interpretada como causadora da catarata ${ }^{2}$ é uma forma de explicar seu aparecimento, pois é durante o cozimento que "os olhos ardem”. Conforme salienta Luz (2003), é importante compreender o papel da (re)significação da saúde e adoecimento, pois é na construção de novos significados que o entendimento do processo histórico envolvido no processo da cura dos doentes amplia o espectro da psicobiologia.

\section{Naturalizações e tolerâncias: a dor normal e a dor dos acidentes}

Durante o trabalho de campo, o contexto e particularidades da Ilha das Fontes delinearam os caminhos percorridos neste capítulo. O que outrora se justificava pela busca dos significados da dor atribuída por marisqueiras necessitou ampliação do olhar e do sentir, pois muitas vezes a dor permanecia silenciada e tolerada. (BOLTANSKI, 2004; HELMAN, 1994)

\footnotetext{
2 Segundo Dall'Oca (2004), a execução de trabalho a céu aberto submete o pescador artesanal ao excesso de sol durante o trabalho, com possiveis implicações no aparecimento de cataratas, lesões degenerativas na pele, queimaduras, envelhecimento precoce ou até dermatites.
} 
Eu já senti dor nas costas, dor nas pernas, senti o corpo inteiro, mas não podia deixar de ir, pois não tinha nada em casa, tinha que ir. A gente consegue suportar a dor porque não é uma dor grave de ir pro hospital. (Tatiana, 27 anos)

Corroborando a narrativa de Tatiana, Solange nos explica sua compreensão acerca dos possíveis impedimentos ao trabalho na maré e sua tolerância aos problemas de saúde,

Quando a gente tá sentindo alguma coisa a gente não vai pra maré. A não ser que seja assim uma dor de cabeça, uma dor que não empate, não é? Porque tem coisa que a gente sente e tem que ir! Eu estou dizendo assim, às vezes a gente tá com uma dor de cabeça fraca, dá pra ir. Às vezes a gente tá se sentindo mal, com problema de pressão. Se a pessoa não fica tonta, dá pra ir, não é? É assim. Nada me impedia de ir pra maré, o que tá impedindo agora é isso3. (Solange, 56 anos)

Segundo Pimenta e Portnoi (1999), o conceito atribuído à dor compreende três componentes: o sensitivo-discriminativo (sensação física), o afetivo-emocional (emocional) e o cognitivo-avaliativo (pensamento). Esse conceito descreve a dor como uma informação transmitida da periferia para o sistema nervoso central, que interage com fatores emocionais e culturais e podem modificar a percepção da informação inicial. A partir das narrativas apresentadas, observa-se que a experiência da dor é um sintoma presente, muitas vezes decorrente de uma jornada de trabalho extensa, percebida, porém tolerada (HELMAN, 1994; PIMENTA; PORTNOI, 1999) em decorrência de necessidades básicas de sobrevivência e da centralidade do trabalho na vida dessas mulheres.

Para resistir a esse contexto de trabalho, as marisqueiras criam estratégias de continuidade do trabalho mesmo com dor em decorrência de cortes na maré, como nos relata Tatiana:

Eu, com um saco na cabeça e de 'barriga', saí correndo e passei o pé na ostra. Chega deu para ver o 'negócio', o nervo do pé. Mesmo assim, no outro dia, eu fui de novo com esse pé inchado, cortado, sangrando. Fui assim mesmo noutro dia. O pé inchado, amarrei um pano, calcei a bota, fui, tirei ostra novamente

3 Solange foi diagnosticada com Câncer Bilateral de Ovários, no momento da entrevista aguardava a cirurgia, sem saber do diagnóstico, do qual só foi informada após o procedimento. 
[...] No terceiro dia eu não aguentei ir mais, porque já estava me dando febre, me deu ingua também. (Tatiana, 27 anos)

No entanto, por mais que a dor seja tolerada, outros indícios são percebidos por Tatiana. $\mathrm{O}$ antes compreendido como dor privada, normal, torna-se pública e anormal, (HELMAN, 1994) com o aparecimento dos sinais de inflamação, justificando a necessidade do relativo repouso da maré:

O tipo de trabalho determina a forma com que os indivíduos cuidam do corpo e da saúde. Para Luc Boltanski (2004), os indivíduos que possuem uma relação instrumental com o corpo, devido as suas atividades laborais, tendem a prestar menos atenção aos fenômenos corporais, "talvez, porque o estabelecimento de uma relação reflexiva com o corpo é pouco compatível com uma utilização intensa do corpo”. (BOLTANSKI, 2004, p. 157)

Em alguns momentos realizam pequenas pausas para alívio da dor na coluna devido às posturas realizadas na maré. Dor esta que, depois do cansaço generalizado referido no processo de coleta, se configura como uma das mais narradas, como se observa nas fala de Jacqueline:

Levantar um pouquinho, a coluna retou, vou descansar um pouquinho se não eu não aguento. A coluna não tá deixando não, já tô agoniada. Essa dor começou no dia que eu fui pro mangue tirar ostra, fui carregar o balde na cabeça, tive que ficar descansando, sentada na canoa, até a hora de vir. Quando eu cheguei em casa não aguentei mais, nem a ostra eu carreguei para terra, que eu não aguentei mais a coluna. (Jacqueline, 34 anos)

A dor descrita por Jacqueline não é interpretada apenas como decorrente do trabalho. Continuando a narrativa, ela explica o processo que desencadeou a referida dor:

Eu também recebi um chute nas costas, sentada catando o marisco, o rapaz veio de lá para cá por causa de fuxico e sem esperar recebi um chute no meio das costas, recebi essa traição do cara que eu morava, a partir da pancada a dor começou. Eu vinha pro trabalho e a dor aumentava. (Jacqueline, 34 anos)

A dor, fruto da violência doméstica sofrida pela mulher, é na maioria das vezes naturalizada, tolerada e não denunciada. Há também a dor que marca as lembranças das dificuldades na maré, uma dor que pouco se tolera, e por isso é relegada ao esquecimento. Falas das suas histórias de acidentes que permanecem na invisibilidade social, e de que sentem até hoje no corpo as mazelas 
de uma injusta história. Essa dor, marcada em Mônica e Jacqueline, é narrada pelo acidente com o barco que virou com seus filhos ainda pequenos:

Marcas eu tenho do perigo que já passei com as crianças em canoa, já virei canoa com eles, carregada de material de pesca, às vezes até com marisco, eles pequeno, ai eu tive que jogar para dentro do mangue para poder salvar eles, mas, tem coisa que eu não gosto nem de lembrar, que foi muito difícil para mim! (Mônica, 40 anos)

Levei ele para maré, ele caiu da canoa. Se sujou todo de lama, ele e a menina, ela ficou pendurada no ‘berço’ da canoa e ele caiu, minha realeza foi que a maré estava baixa. (Jacqueline, 34 anos)

Observa-se que além dos aspectos sociais, a religião também exerce forte ligação na compreensão da dor, sua naturalização, tolerância e na maneira como as pessoas percebem os problemas de saúde. (HELMAN, 1994) A narrativa de Solange traduz essa interface da religião com o problema de saúde que vem enfrentando:

Eu sempre vou para igreja, porque eu vejo muita gente sendo curada e nem precisa operar. Eu fui hoje na igreja do Iguatemi4, porque tem coisas que Deus faz e tem coisas também que Deus livra. E quando eu vim de lá, eu sai melhor, porque minha barriga aqui, ela fica assim ô, alta, altona assim. E hoje ela estava vazia, parece que já saiu alguma coisa, assim de dentro. Deus leva as doenças. (Solange, 56 anos)

Para Pimenta e Portnoi (1999), as religiões desempenham um importante papel importante no processo de socialização ao moldar a percepção do indivíduo sobre si mesmo e também a sua resposta a dor. Por isso, são a partir das relações que os indivíduos estabelecem com o corpo, o habitus corporal dos membros de um grupo, que são expressas e definidas as práticas de intervenção e procura dos possíveis tratamentos, pautadas na relação estabelecida entre os profissionais de saúde e o paciente.

4 Solange é evangélica e, com certa frequência, desloca-se a Salvador para assistir ao culto na Igreja Universal, localizada na Avenida Luis Eduardo Magalhães. 


\section{Itinerários terapêuticos e comunicação médico-paciente: aproximações necessárias}

Assim, como são vastas as possibilidades de tolerância à dor, são vastos os artifícios, ensinamentos e caminhos para tratá-las. As alternativas permeiam em torno da "prática informal” - automedicação, aconselhamento com outras pessoas, assistência em igreja e cultos -, passando pela 'alternativa popular (curandeiros), até chegar ao “setor profissional” - fisioterapeuta, enfermeiro, médico. (HELMAN, 1994; KLEINMAN, 1978) Consiste nessas alternativas a eleição de diferentes sistemas de “cura” ou a integração das diversas assistências.

Os itinerários terapêuticos podem ser entendidos como ações humanas que se constituem pela junção de atos distintos que compõem uma unidade articulada, capaz de gerar significações no curso de suas ações. (ALVES; SOUZA, 1999) A prática médica oficial relatada por Germina, quanto ao uso de vacinas próprias da infância, complementa a prática médica familiar representada pelo uso de chá caseiro. Sobre o uso de chás, Tatiana nos explica algumas folhas medicinais utilizadas por ela nos cuidados à saúde:

Para as pessoas que sentem a dor de cabeça tem o vick, [...] tem também a cidreira, se você tiver muito cansada da maré e não tiver com sono pode fazer o chá de cidreira e tomar, o chá de melissa, você pode tomar porque é calmante e vai te dar sono. Também tem 'amesca', que eu já falei da 'amesca', tem a folha do mangue mesmo, que se você tiver com dor de barriga pode mastigar uma folha madura, $e$ tem também a 'bezetacil', o 'arrozinho', aqui mesmo tem muito 'arrozinho' lá na frente, ele é bom para inflamação. (Tatiana, 27 anos)

Vários significados, importância e tratamentos foram gravados no corpo através dos séculos, nas diferentes sociedades e culturas. Algumas práticas populares surgem como consequência da necessidade de se resolver problemas diários e "pelo fato de darem certo se transformam em convicções, em crenças e são repassadas de um indivíduo para outro e de uma geração para outra”. (SILVA, 1996, p. 75) Assim, consideramos crenças como o conhecimento advindo do senso comum repassado de geração a geração, adquirido de forma empírica e que faz parte da cultura popular.

Essas crenças transitam em explicações simbólicas de interpretação e tratamento como a observada na fala de Tatiana, após um corte com a ostra, "eu pensei que tivesse até cortado a veia do meu dedo". O conhecimento popular 
transmitido pelos pais perpassa no uso dos recursos contidos no próprio meio natural como forma de tratamento: o corte na maré é visto como perigoso, "se você toma um talho grande mesmo e a maré tiver seca você morre ali", mas inúmeras são as estratégias e teorias para conter o sangramento, no episódio narrado por Tatiana, um vasto arsenal terapêutico foi apresentado como sua compreensão sobre a contenção de um corte para permitir a continuidade do trabalho.

Em outra passagem de sua narrativa, Tatiana nos explica um dos vários episódios de dor abdominal e diarreia, relatando sua forma de amenizar a sensação e poder retornar ao ofício:

Quando eu vou para maré é uma dor de barriga, diarréia, de as pernas da pessoa ficar fraca mesmo, de você cair. Eu já caí dentro do mangue assim ô, oi, oi, oi, e a dor de barriga em cima ali ô, sem sair de você ali, e você suando frio, uma dor insuportável, tomando minhas pernas toda, que eu estava com as pernas fraca, que eu achei até que eu ia cair no mangue. Foi que eu mastiguei a folha do mangue, me sentei um pouquinho e depois foi aliviando a dor de barriga e eu consegui trabalhar, a gente que mora aqui conhece um bocado de folha. (Tatiana, 27 anos)

O modelo explicativo leigo (HELMAN, 1994; KLEINMAN, 1978) de tratamento utilizado por Tatiana é definido como um conjunto de ideias construídas como resposta a experiência de doença (illness). Essas práticas se justificam principalmente por meio da crença na ação terapêutica dos recursos utilizados. Ao se tratar de experiências vivenciadas dentro do processo saúde-doença é impossível desapropriar os sujeitos das concepções e representações arraigadas ao saber cultural.

Outras alternativas são observadas como o uso de massagens terapêuticas para alívio da dor na coluna:

Eu passo dotozinho (pomada chinesa, muito comum no comércio), ai eu sempre dou massagem, boto meia e passa. Tempo frio mesmo eu não aguento. (Germina, 49 anos)

Quando eu chego da maré eu vou deitar, eu tenho que botar água quente nas minhas costas, molhar um pano assim, botar a água para ferver, molhar o pano e botar ele úmido, bem quente em cima de minhas costas para aliviar a dor. Quando é assim eu também faço umas massagens com as mãos. (Tatiana, 27 anos) 
Essa relação entre práticas científicas e populares encontra inúmeras dificuldades, principalmente no que concerne ao discurso do médico-paciente. (BOLTANSKI, 2004) Como é observado na narrativa de Tatiana sobre o contra ponto entre o discurso médico e o conhecimento popular sobre a relação entre dor e fraqueza:

Eu fui no médico, ele somente passou vitamina, sulfato ferrosos. Eu acho que sulfato ferroso é para quem tem anemia. E eu preciso me fortificar, preciso é de uma vitamina, de cálcio pros ossos. Eu acho que tô com fraqueza nos ossos, porque minha mãe sempre me dizia que quem sente muitas dores nas pernas é fraqueza nos ossos, precisa de um cálcio. (Tatiana, 27 anos)

Observa-se que o primeiro trabalho na construção das representações populares da doença vai consistir em trazer o desconhecido ao conhecido, injetando sentido nos termos emprestados pelo discurso médico. Para que seja possível o sentido, esses termos devem coincidir com categorias cuja manipulação lhes seja familiar. (BOLTANSKI, 2004) Algumas das dificuldades e conflitos na relação médico-paciente frente aos membros das classes populares são reflexos da reserva em lhes fornecer uma informação única, clara a respeito de sua doença e do tratamento prescrito, como se observa na fala de Germina:

Quando eu era pequena eu sempre ficava entrevada em cima da cama, eu não andava. Eu sentia muita dor nos braços e nas penas, ai eu ia pro médico nos braços dos outros. Ai eu cuidei, entrei em tratamento, tomando injeção, toma injeção de três em três dias, eu tomei umas 15 de benzetacil, ai eu enjoei e disse assim, eu não vou tomar mais. Voltei no médico e ele me perguntou se eu tomei direito e falou 'você tem que cuidar dessa perna, você pode ficar aleijada'. Eu acho que foi doença no osso mesmo, que dói por dentro, eu acho que énos nervos, ai quando eu tomo frio ataca. (Germina, 49 anos)

Segundo Luc Boltanski (2004), as explicações variam em função da classe social do paciente. A atitude médica frente às classes populares centra-se em dar ordens sem comentários, em vez de conselhos argumentados. Dessa forma, estabelece-se uma relação de autoridade, na qual o não cumprimento das prescrições levam a sanções estabelecidas que acarretarão consequências à saúde física da paciente.

A frequência e a intensidade das relações que os doentes mantêm com o médico crescem quando se sobe na hierarquia social, quando diminui 
a distância social entre o médico e seu paciente. (BOLTANSKI, 2004) A compreensão e memorização do discurso médico pelas classes sociais são feitas por meio de um trabalho de reinterpretação - de forma a fazer sentido. Neste sentido, reproduzem o que é diverso pela comparação e analogia, substituindo as categorias da medicina científica por categorias populares, simples e antigas. Sendo que cabe ao médico saber explicar ao paciente utilizando palavras com as quais este esteja familiarizado.

\section{Considerações Finais}

Ao assumir como objeto de estudo a pesca artesanal exercida pelas mulheres, procuramos nos aproximar não apenas com as técnicas da avaliação biomecânica da Fisioterapia, mas extrapolar esse olhar sistemático para compreender o corpo em sua dimensão subjetiva e cultural. A partir da teia de significados presentes nas narrativas das marisqueiras, observamos que o corpo e os problemas de saúde, relativos tanto ao trabalho quanto às doenças em geral, são representados, ressignificados e passíveis de diferentes leituras, consoante ao contexto social e aos diferentes campos do saber que atuam mutuamente.

Defrontamo-nos com narrativas de uma dor no corpo generalizada e significada como um cansaço, que não as impede de exercerem o ofício. Retomando a alusão à dinâmica estrutura-agência, evidenciamos a convergência com a visão de Bourdieu (2009, p. 58) de que as práticas são "imediatamente ajustadas às estruturas”, em um processo mais amplo que reforça continuamente a necessidade de "harmonização das experiências dos sujeitos". No universo das marisqueiras, as dores e outras mazelas associadas ao trabalho que desenvolvem, tendem a ser minimizadas a partir de uma lógica na qual prevalece o senso prático da sobrevivência.

Dessa forma, a dor é naturalizada e tolerada, pois as condições de sobrevivência impõem a continuidade do trabalho, mesmo com a presença da dor no corpo pelo cansaço ou ferimentos. As estratégias de naturalização dessa dor inscrevem no corpo limites que são expressos com o avançar da idade, quando o corpo sofre ainda as consequências do desamparo social e do não reconhecimento da contribuição social e dos direitos trabalhistas dessa atividade econômica. Neste sentido, revela-se especialmente oportuno a realização de estudos futuros que explorem, entre outros aspectos, a in- 
cidência de marcadores geracionais na produção de sentidos sobre o corpo, condições de trabalho e saúde em relação à prática da mariscagem, assim como, os limites e possibilidades do cuidado à saúde - institucional, pessoal - neste universo.

\section{Referências}

ALVES, P. C.; SOUZA, I. M. Escolha e avaliação de tratamento para problemas de saúde: considerações sobre itinerários terapêuticos. In: RABELO, M. C.; ALVES, P. C.; SOUZA, I. M. A. Experiência de doença e narrativa. Rio de Janeiro: Fiocruz, 1999. p. 125-38.

BOLTANSKI, L. As classes sociais e o corpo. 4. ed. Rio de Janeiro: Graal; São Paulo: Paz e Terra, 2004.

BOURDIEU, P. O poder simbólico. Rio de Janeiro: Bertrand Brasil; Lisboa: Difel, 1989. (Memória e sociedade).

BOURDIEU, P. O senso prático. Petrópolis: Vozes, 2009.

DALL'OCA, A. V. Aspectos socioeconômicos, de trabalho e de saúde dos pescadores do Mato Grosso do Sol. 2004. 52 f. Dissertação (Mestrado em Saúde Coletiva) Universidade Federal de Mato Grosso do Sul, Campo Grande, 2004.

DIEGUES, A. C. S. Pescadores, camponeses e trabalhadores do mar. São Paulo: Ática, 1983. (Ensaios, n. 94).

GUÉRIN, F. et al. Compreender o trabalho para transformá-lo: a prática da ergonomia. São Paulo: USP, 2005.

HELMAN, C. G. Dor e cultura. In: HELMAN, C. G. Cultura, saúde e doença. Porto Alegre: Artes Médicas, 1994· p. 165-175. (Biomedica).

KLEINMAN, A. Concepts and a model for the comparison of medical systems as culturalsystems. Social Science \& Medicine, Amsterdã, v. 12, p. 85-93, 1978.

LE BRETON, D. Adeus ao corpo: antropologia e sociedade. Tradução de Marina Appenzeller. 5. ed. Campinas: Papirus, 2003.

LE BRETON, D. A Sociologia do corpo. 2. ed. Petrópolis, RJ: Vozes, 2007.

LUZ, M. T. Novos saberes e práticas em saúde coletiva: estudo sobre racionalidades médicas e atividades corporais. São Paulo: Hucitec, 2003.

MAUSS, M. Sociologia e antropologia. São Paulo: EPU, 1974.

MERLEAU-PONTY, M. Fenomenologia da percepção. 2. ed. São Paulo: Martins Fontes, 1999 . 
MOREIRA, M. A. C. et al. Estudo comparativo de sintomas respiratórios e função pulmonar com doença pulmonar obstrutiva crônica relacionada à exposição à fumaça de lenha e ao tabaco. Jornal Brasileiro de Pneumologia, São Paulo, v. 34, n. 9, p. $667-674,2008$.

PENA, P. G. L.; FREITAS, M. C. S.; CARDIM, A. Trabalho artesanal, cadências infernais e lesões por esforços repetitivos: estudo de caso em uma comunidade de mariscadeiras na Ilha de Maré, Bahia. Ciência \& Saúde Coletiva, Rio de Janeiro, v. 16, n. 8, ago. 2011.

PIMENTA, C. A. M.; PORTNOI, A.G. Dor e cultura. In: CARVALHO, M. M. M. J. (Org.). Dor: um estudo multidisciplinar. São Paulo: Summus, 1999. p. 159-173.

RAMAZZINI, B. As doenças dos trabalhadores. São Paulo: Fundacentro, 1985.

SILVA, L. G. A faina, a festa e o rito: gentes do mar e escravidão no Brasil (sec. XVII ao XIX). 1996. 256 f. Tese (Doutorado em História Social) - Universidade de São Paulo, São Paulo, 1996.

YOUNG, A. The anthropologies of illness and sickness. Annual Review of Anthropology, Palo Alto, v. 11, p. 257-285, Oct. 1982. 


\title{
Riscos ocupacionais na coleta de materiais recicláveis
}

\section{percepção e condicionantes} em uma cooperativa familiar

\author{
DENISE ALVES MIRANDA DE OLIVEIRA \\ LUIZ ROBERTO SANTOS MORAES \\ SERGIOTRAD
}

\section{Introdução}

No Brasil, cenário econômico de uma produção diária de toneladas de resíduos sólidos industriais, a coleta seletiva aparece como alternativa para os trabalhadores menos qualificados para o mercado. Contudo, diante da ausência de políticas públicas que incentivem a reciclagem dos resíduos, geralmente a atividade é exercida de forma autônoma, informal e pouco organizada por famílias e coletivos sociais em situação de pobreza, chamados popularmente de "catadores".

Apesar de exercer um papel social importante na cadeia da coleta seletiva de resíduos, a categoria enfrenta ambientes e condições precárias de trabalho. Os acidentes e doenças tendem a acontecer em decorrência dessa precarização do trabalho, favorecendo as enfermidades ocupacionais. (CAVALCANTE; FRANCO, 2007; MAIA, 2013) Velloso, Santos e Anjos (1997), e Gonçalves (2005) destacam que a capacidade de um trabalhador identificar os perigos na sua atividade, assim como de atribuir significado a situações 
que podem ocasionar acidentes e lesões, sofrer interferência do contexto, das motivações internas, das experiências anteriores do trabalhador e condições ambientais. Por sua vez, autores como Motta (2002), Dook e Lognecker (2004) e Freitas (2000) consideram que a sensação e condições de segurança, a autogestão e o conhecimento também podem influenciar nas ações de controle e formas de decisão a serem adotadas pelos trabalhadores.

De acordo com Porto (2000), as conceituações sobre os riscos ocupacionais são tradicionalmente associadas a doenças e acidentes de trabalho a partir dos efeitos mais visíveis e decorrentes do ambiente e dos instrumentos, das substâncias, desconsiderando as particularidades de processos de trabalhos singulares e da variabilidade humana. Essas abordagens abarcam apenas aquela faceta do trabalho passível de antecipação, ou de suposição de antecipação, posto que despreza a parte que não se pode prever, sobre a qual não se pode objetivar, excluindo da sua concepção a experiência real do trabalho. $\mathrm{O}$ autor propõe então uma concepção mais abrangente de risco, a qual norteou o presente trabalho.

São destacados também desafios no plano metodológico. Nouroudine (2004) chama a atenção para a necessidade de investir em estratégias que favoreçam a escuta dos trabalhadores, contrapondo-se à abordagem técnica e estatística do risco. Trata-se de reconhecer que o sentido do risco construído pelos sujeitos pode diferir daquele que se sobressai nas abordagens estatísticas.

Com base no exposto, este trabalho procurou investigar como trabalhadores da reciclagem e com baixa renda enfrentam esses riscos no município de Salvador. Em termos mais específicos, o estudo analisou a percepção dos riscos ocupacionais em uma cooperativa local, considerando preliminarmente sentidos e significados sobre saúde-doença associados com a atividade laboral em foco.

Adotou-se uma metodologia qualitativa, considerando a intenção de apreender dados subjetivos, relacionados ao trabalho como experiências, sentidos, significados, valores, crenças, apreciações e costumes dos sujeitos entrevistados. (CRUZ, 1994) A entrevista individual e a observação participante na cooperativa selecionada para o estudo cujas características serão descritas a seguir, foram as principais técnicas utilizadas para a produção de dados.

De forma complementar, foi utilizado um diário de campo, instrumento de registro das impressões pessoais sobre o campo que subsidiou as análises e informações coletadas. A análise dos dados foi feita com base na análise 
do discurso, visando realizar uma reflexão sobre as condições de produção e apreensão da significação de textos na comunicação verbal e não verbal, nos detalhes dos gestos e expressões dos trabalhadores. (BRANDÃO, 2004; QUEIROZ, et al. 2007; ROSS; KYLE, 1982)

As visitas ao campo ocorriam em alguns dias da semana e a observação abrangia o cotidiano e a rotina de atividades em três ambientes: a sede da cooperativa, onde parte dos cooperativados permaneciam, um parque empresarial próximo ao galpão, o percurso entre o parque empresarial e a cooperativa. A incursão no campo ocorreu entre março e julho de 2010. Na produção e análise de dados oriundos das entrevistas individuais, da observação participante e, das notas do diário de campo, foram considerados dois eixos temáticos: contextos de trabalho e processo saúde-doença; percepção de risco e condicionantes.

\section{Resultados e discussão}

\section{Contextos e condições de trabalho - sentidos e experiências associados à saúde, acidentes e doenças ocupacionais.}

A cooperativa está localizada na periferia de Salvador, em uma região marcada por baixos índices de desenvolvimento social. Situada no térreo de uma casa alugada, possui um único cômodo para abrigar todas as atividades, das administrativas à seleção, separação e armazenamento do material. O cômodo possui um banheiro sem porta, com um tecido protegendo a entrada. Na frente da casa não há cobertura e o material é selecionado e guardado sobre o chão, dentro de baldes, dos carrinhos para coleta ou de big bags. Quando ocorre a repartição de lanches, como não há local adequado para as refeições, come-se em qualquer lugar, não existindo uma preocupação com o lavar as mãos após manipularem os resíduos.

Os laços familiares predominam entre os cooperativados como mãe, filhos, afilhados e sobrinhos, totalizando dez associados. Cinco dos trabalhadores são jovens com menos de vinte anos, três deles estudam e trabalham somente um turno. Cabe aos quatro jovens homens as tarefas mais pesadas fora da cooperativa. A jovem Isabela trabalha como auxiliar administrativa, os demais cooperativados que atuam na sede são mais velhos, com mais de quarenta e cinco anos. Três deles - Rege, Dolores e Iara -, há dez anos, fun- 
daram a cooperativa e sempre convidaram parentes ou pessoas conhecidas para se unir ao grupo.

As principais fontes de renda do grupo são o trabalho na coleta seletiva de resíduos e o Bolsa Família, um benefício recebido por seis associados. Consideram que o rendimento não é satisfatório, mas provê as necessidades básicas das famílias. Para os associados mais antigos, a cooperativa representa um fator de inclusão social em suas vidas. Mesmo diante de todas as dificuldades enfrentadas, como baixo rendimento, falta de insumos, exposição a riscos, sobrecarga de trabalho, sentem-se motivados a continuar equacionando e superando tais questões na esperança de dias melhores, traduzidos como aumento do rendimento, acesso a insumos e garantias sociais, a exemplo da previdência social. Entre os mais velhos, é marcante a projeção otimista em relação ao futuro, pois acreditam que a articulação com os poderes públicos lhes garantirá um dia condições dignas de trabalho.

Os cooperativados que atuam na sede, caracterizam o espaço como uma extensão da casa, ambiente de trabalho harmonioso, seguro, passando um sentimento de posse e de aconchego. Os mesmos se consideram pessoas com vínculos familiares e afetivos sólidos, que se preocupam umas com as outras, pois na cooperativa não há chefes, apenas amigos e relações de autonomia.

Na narrativa dos mais velhos e experientes, a saúde é um fator determinante na habilidade para o trabalho, assim como a boa alimentação, energia, alegria, força, equilíbrio entre o corpo e a mente, boa aparência, sentir-se bem e ausência de doenças. A doença, por sua parte, é uma "coisa que ninguém deseja ter”, uma incapacidade para o trabalho. Visão que coincide com aquela encontrada na pesquisa de Porto e colaboradores (2004). De certa forma, entre os veteranos da cooperativa, prevalece a ideia de que o trabalho é uma atividade que garante a subsistência, e só é possível de ser realizado quando se tem saúde.

O corpo dos cooperativados é um instrumento de trabalho e perceber este corpo como "sadio" se torna essencial para garantir inclusive sua permanência na cooperativa. Sem amparos sociais, como o da Previdência Social, temem que, sem sua própria força de trabalho, representada pela autoafirmação da saúde e negação das queixas atuais como ocupacionais, sejam considerados rejeitos e, assim como os resíduos sólidos, sejam rejeitados e desprezados. Silva (2005), ao observar que a relação corpo e doença assume significados diferentes em cada grupo social, destaca que, nos estratos 
sociais de menor renda, o corpo representa o principal instrumento de trabalho, o meio de produção.

Neste caso, admitir alguma sensação mórbida significa a incapacidade para o trabalho, ou seja, para sustentar a si mesmo e sua família. A própria percepção da doença pode ser negada até os limites da capacidade de se manter de pé e trabalhando. Embora percebam e citem a existência de fatores de risco associados ao trabalho que realizam, a maioria dos entrevistados, especialmente os mais velhos, não reconhecem as suas queixas ou os problemas de saúde atuais como consequência do trabalho. Justificam-se atribuindo as causas a outros fatores como idade e doenças prévias.

Minha coluna não tem nada a ver com a cooperativa. É assim: magoou [...] Então foi muito trabalho, estava muito cheio de material, a gente teve que puxar tudo para um lado só. Então foi peso, sabe? Aí magoou. Não deve ser daqui não. E a minha idade também já está pra ter esses problemas de coluna. (Dolores)

Mesmo diante de uma atividade insalubre, pouco mencionam a presença de doenças associadas à atividade laboral. Apenas os acidentes perfuro-cortantes, as quedas e as infecções de pele são associados à ocupação, o que coincide com os dados encontrados por Ferreira e Anjos (2001), Porto e colaboradores (2004), Miura (2004), Medeiros e Macêdo (2006) e Cavalcante e Franco (2007).

Os profissionais parecem temer reconhecer que este tipo de atividade cause de fato alguma doença. No caso de Rege, por exemplo, ela relaciona a Lesão por Esforço Repetitivo (LER) a outros trabalhos anteriores como o rejuntamento, limpeza de vidros, lavar e passar ferro em roupas. Outras queixas foram apresentadas pelos profissionais como hepatopatia, erisipela, cefaleia, hipertensão, dores de coluna, alergias respiratórias, LER, mas, não são relacionadas à atividade laboral, principalmente no grupo dos mais velhos.

Em geral, nas experiências pessoais com doenças ocupacionais, prevalece uma dificuldade em reconhecer a enfermidade e a dor do momento presente como laboral. Os acidentes adquirem um caráter real de infortúnio, e as doenças assumem uma possibilidade abstrata.

Às vezes quando termino o trabalho dói, se eu pisar de mau jeito, ou forçar a barra, mesmo! Como ontem, que foi barra pesada mesmo, pra limpar essa área todinha! Já desci a ladeira capengando, mas dá pra levar! (Rege) 
Doença aqui só por causa da poeira! Porque eu fico espirrando, só isso. [...] Espirro, mas não muito, só quando tem papel [...] Algumas vezes eu fico com alergia. (Isabela)

O grupo acima de 47 anos não se refere à dor após a jornada de trabalho. A ocorrência da dor parece estar relacionada ao efeito do tipo de atividade desenvolvida e ao grau de satisfação pessoal na atividade. Apresenta-se uma relação diretamente proporcional à atividade e inversamente proporcional à satisfação.

Dificuldade é pegar peso, carregar 'bergue' (Beg ou sacola em inglês) é o dia todo carregando ‘bergue’. Ontem, de tão pesado que estava ficou ruim de puxar. (Danilo, 19 anos)

Não sou de sentir dor, não sinto nada. Fico é bem quando termino. (Iara)

Minha dor não tem nada daqui. (Dolores)

Quando questionados sobre acidentes de trabalho, a maioria se referiu a já ter sofrido um ou mais acidentes, sendo recorrente a menção a acidentes com objetos perfuro-cortantes durante a manipulação dos resíduos.

\section{Percepção sobre riscos no ambiente de trabalho e seus condicionantes}

Ao analisar as narrativas dos informantes sobre os riscos associados à atividade que realizam, constata-se que a percepção do risco pode variar tanto em função das caraterísticas dos sujeitos - geração, gênero, escolaridade etc., quanto em função do contexto e/ou particularidades do trabalho, destacando-se, dentre outros, os espaços envolvidos no processo de reciclagem, o tipo de atividade realizada, o material a ser reciclado.

Evidencia-se sobretudo que a preocupação com a sobrevivência se impõe, contribuindo para minimizar ou mesmo negar as existências de riscos ocupacionais. A percepção de risco é diminuída e comprometida frente à necessidade de sobrevivência. $O$ valor recai sobre o material reciclável, que gera rendimento e subsistência, e o risco assume um papel sutil no imaginário.

As diferenças geracionais já foram apontadas na seção anterior e revelam-se mais evidentes quando consideramos a percepção sobre risco. São encontradas diferenças significativas entre as visões dos trabalhadores mais 
novos, com idade até vinte anos, e o grupo dos mais velhos, com mais experiência no mercado de trabalho e idade acima de quarenta e cinco anos.

Os jovens demonstram não se alinhar com a visão da cooperativa como um ambiente de segurança. Portam uma percepção de risco mais apurada e diversificada. Dos mais velhos, somente Dolores concorda com a visão dos jovens, como nas ponderações sobre os riscos à saúde no ambiente da cooperativa:

Muito calor, muito incômodo! Aqui esse galpão que a gente está, as condições são muito ruins. Então, eu tenho medo pela vida dos outros. Até agora não teve nenhum problema de saúde com ninguém. [...] A cozinha está em mal estado. Tem muita barata na cozinha por não ser rebocada, não tem contra piso [...] Então, aqui não é um local indicado pra a gente está trabalhando. Se chove, entra água aqui no galpão. Se faz sol, ninguém aguenta o calor. Se tivesse o triciclo motorizado, ia ser melhor, por que aqui tem gente burro de carga. (Dolores)

Segurança? Aqui devia é ter tudo! Luva, a roupa, bota... É pra ter isso! Porque aqui, pra não ter acidente, tem que ter mais gente. Pra pessoa não pegar tanto peso e se machucar. (Daniel)

Entre os demais integrantes da cooperativa, prevalece a percepção de segurança difundida pelos mais experientes. Em seus depoimentos, não demonstram perceber os riscos do local ou a questão de risco não se expressa como um evento marcante. Em suas falas, constata-se que, uma vez feita a primeira triagem dos resíduos trazidos para a cooperativa, o material que manipulam parece perder o potencial de risco: uma vez conhecido, parece que se torna inofensivo. Esta conclusão deriva também de observações de campo, nas quais se evidenciou a rejeição do uso da luva na sede. Esta era usada exclusivamente no complexo fabril. A propósito: foram recorrentes os discursos de que "a sede é limpa”, rejeitando a conotação de sujeira e risco. Afinal, conforme mencionado, naquele galpão eles se encontram em uma atmosfera “de lar”, culturalmente associado à segurança.

Mesmo quando admitem que manipulam materiais cortantes e perfurantes e chegam a fazer alusão ao risco, não se observa um temor a tais exposições. Os relatos exacerbam a capacidade de se controlar o risco:

Esse trabalho tem muitos riscos porque a gente trabalha com vidro, ferro, lata enferrujada, tanta coisa e tem muitos riscos. Mas, graças 
a Deus a gente aqui tem cuidado. Coloca luva, pra não se machucar. (Rege, 47 anos)

Esta visão positivada também é encontrada entre os catadores investigados por Velloso, Santos e Anjos (1997). Os relatos sobre prevenção aos riscos no trabalho são semelhantes, ao tempo em que referiam a ocorrência de diversos tipos de acidentes, apesar das estratégias preventivas.

Geralmente o reconhecimento de que são expostos à determinada substância como um fator de risco, só é feito, na maioria das vezes, depois do contato físico e das repercussões sobre o corpo.

Uma vez, quando a gente não sabia do pó de alumínio, vimos aquele pozinho e aí, penetrou! Ficou todo coçando! E quanto mais a gente coçava, mais coçava! Vamos aprendendo. À medida que vamos trabalhando, vamos aprendendo a conhecer as coisas. (Iara, 47 anos)

Com respeito ao tipo de substâncias que manipulam, identificou-se um certo destaque às substâncias em pó: o grupo costuma fazer uma escala de perigo da exposição a partir de sua natureza. Avaliam o risco quantificando o volume e a natureza do pó no contêiner, lugar de onde retiram o material reciclável. O conhecimento construído, a partir das informações disponíveis, auxilia na tomada de decisões e na avaliação do risco-benefício. Reconhecem o risco das poeiras e conceituam o nível de perigo do pó de alumínio como alto: "Se tiver pouco pó de alumínio dá pra a gente pegar, às vezes! Se tiver muito pó, aí não dá pra gente pegar. Porque o pó alumínio faz mal, até pra gente respirar também”. (Iara)

A satisfação pessoal no trabalho aparece entre os adultos experientes como um fator que minimiza a percepção de risco. Em contrapartida, no grupo dos jovens, que executam as tarefas mais pesadas e de transporte, relata-se com mais frequência os riscos durante as atividades. Pode-se depreender aqui que a percepção de riscos ocupacionais na cooperativa tem uma relação direta com a satisfação profissional e, mais uma vez, reitera-se as diferenças geracionais.

No tocante à relação entre risco e tipo de trabalho desempenhado, constata-se que a percepção de risco é maior entre os cooperativados que executam as atividades consideradas mais árduas e perigosas. Os demais, que geralmente permanecem no ambiente supostamente mais seguro da sede, 
não costumam referenciar tais riscos, já que o enfrentamento do risco é tido como inevitável, tornando-se portanto desnecessário ratificá-lo. Este último aspecto é referido na literatura especializada. (CAVALCANTE; FRANCO, 2007; CHAMON; MORAES, 2011) Contudo, existe um reconhecimento comum sobre a prevalência dos acidentes com materiais perfuro cortantes e doenças de pele de origem ocupacional.

Com respeito à espacialização do risco, vamos encontrar uma percepção diferenciada entre aqueles que atuam no espaço "de dentro" - a sede da cooperativa, e o espaço "de fora" que corresponde ao espaço do parque empresarial próximo ao galpão, bem como ao caminho que se percorre entre esses dois espaços. Os mais jovens, que são os responsáveis pela coleta seletiva no referido parque, reconhecem o complexo de fábricas como um ambiente de exposição a diferentes riscos de acidentes relacionados tanto ao transporte da carga quanto ao de seu manuseio. No primeiro caso figurariam os acidentes de percurso e, no segundo, os cortes, infecções por pós-residuais e problemas de saúde decorrentes da sobrecarga de trabalho e do levantamento excessivo de peso etc.

De fato, foram destacados nas falas dos jovens os riscos ergonômicos, concretizados em experiências frequentes de dores no corpo, principalmente no segmento dos braços, coluna e pernas. Com base nos depoimentos colhidos, percebe-se que o percurso realizado com o carro que transporta a carga a ser reciclada entre o complexo empresarial até a cooperativa é difícil, perigoso e cansativo. Foram enfatizados alguns fatores considerados como agravantes à saúde e risco de acidente no trajeto realizado, tais como: o peso da carga, o qual, além de ser considerado como causa principal das dores no corpo, ao se somar às más condições de conservação dos carrinhos, aumenta a probabilidade desses "virarem", o fato de percorrerem um trajeto longo, com risco de atropelamento durante a travessia da estrada BA-528, de quedas à exposição ao sol.

Um dos cooperativados, Daniel, narrou um episódio de acidente no qual um carrinho cheio caiu em cima de dois jovens da cooperativa, machucando-os na perna e na cabeça. Apesar do conhecimento demonstrado sobre os riscos a que estavam apostos e do destaque conferido ao acidente relatado, esses trabalhadores admitiram que não conhecem exatamente o que as fábricas produzem, nem quais substâncias são desprezadas e depositadas nos contêineres. Em seus relatos, contudo, mencionaram algumas 
das substâncias provenientes das empresas como pó de alumínio, de serra e de vidro; assim como resíduos de tinta, solvente e alimentos deteriorados.

Em relação à tarefa de transporte e compactação da carga durante a coleta de materiais, a atividade é considerada como eminentemente masculina e dos jovens pela necessidade de habilidades como agilidade, coragem e força. Entretanto, os jovens temem e relatam os possíveis acidentes, como o risco de queda e a possibilidade do carrinho virar.

No entanto, a questão do rendimento é ambígua, pois quando se trata da satisfação profissional, o importante parece ser a identidade promovida pela filiação à cooperativa. Já quando se trata da percepção de risco, o valor é atribuído ao rendimento e não à probabilidade dos riscos, permitindo a conclusão mais importante de que os riscos são: a satisfação, a identidade profissional e o rendimento conferidos pela cooperativa.

\section{Risco e Sobrevivência}

A respeito da exposição ocupacional diante das circunstâncias e resíduos desconhecidos, não foi observado um sentimento de preocupação, de antecipação ou uma atitude preventiva. As possíveis consequências adversas são ignoradas e as percepções do risco costumam acontecer no cotidiano e após exposições com consequências deletérias sobre o corpo. Apenas os riscos palpáveis e visíveis são percebidos e referidos. E quando assumidos como presentes, a tomada de decisão sobre o risco é o enfrentamento, que parece garantir uma classificação de superpoder, de superação e vitória. $\mathrm{O}$ risco percebido só é encarado quando há benefícios compensatórios de tais exposições e quando o controle dos processos permite que a gestão seja facilitada. A auto-responsabilização e culpabilização por acidentes e doenças ocupacionais manifestadas levam a crer que este comportamento cauteloso é compreendido como medida viável de proteção aos trabalhadores e prevenção de acidentes e doenças.

É importante assinalar os aspectos emocionais e cognitivos para a elaboração do que seria risco entre esses profissionais, justificando a ocultação dos riscos, julgando-os inexistentes ou superáveis. (LUCCA; CORTEZ; TOSETTO, 2011) Na presença ou ausência do risco percebido, a coleta de materiais recicláveis precisa ser realizada, pois é meio de sobrevivência. Neste contexto, prevalece a negação da doença, a aceitação, naturalização e mini- 
mização do risco. A percepção do risco está no nível do palpável, do visível. Aquilo que pode ser visto e sentido como os cortes, as infecções de pele, as substâncias em pó, os quais são facilmente percebidos e identificados como riscos ocupacionais, todos os demais ficam ocultos.

Prevaleceu no grupo investigado o entendimento de que o risco é inerente aos resíduos sólidos e, portanto, à profissão que desempenham. A relação de negação e minimização do risco é consolidada coletivamente a partir da necessidade de sobrevivência do catador e de sua família. A diminuta referência à percepção do risco aparece como estratégia defensiva, que possibilita a permanência na atividade de coleta, sem maiores repercussões psicológicas como o medo, o estresse e anseios, surgindo como uma função protetora. (CARDOZO, 2009; CAVALCANTE; FRANCO, 2007)

A não resistência, oferecida pelos homens na execução das atividades percebidas como arriscadas, deve-se ao perfil de solidariedade e por serem filhos e sobrinhos de cooperativados que definem a divisão de tarefas, pairando uma ideia de autoridade/obediência.

A perspectiva da inter-relação entre pessoa e ambiente naturaliza a abordagem do risco como se o enfrentamento fosse algo inerente à atividade, parecendo tornar invisível e insignificante o potencial de risco para o catador de materiais recicláveis. O valor, importante na caracterização do risco, é atribuído ao material reciclável e não a fonte potencial de dano.

Os catadores destacam por certo a situação de informalidade como um agravante aos riscos vivenciados no dia a dia, pois em todas as situações de doenças ocorridas no grupo, que resultaram em muitos dias de afastamento, os cooperativados tiveram prejuízos financeiros, recorrente dos descontos ocorridos devido às faltas e consequente redução na coleta. Os relatos exprimem que sem previdência, por vezes, negligenciam a saúde, colocando em primeiro plano a necessidade básica da subsistência, percebendo tal postura como um fator de risco.

\section{Enfrentamento ou gestão do risco}

Enquanto os jovens salientaram que não tinham governabilidade sobre os problemas enfrentados na rua, o que tornava mais aguda a percepção de vulnerabilidade de seu trabalho no grupo dos cooperativados mais velhos, que são maioria, prevaleceu o entendimento de que eles são os principais 
responsáveis pela produção de acidentes, uma vez que reconhecem que o risco é entendido como controlável, sendo o comportamento cauteloso suficiente para a prevenção de acidentes.

[...] Furou e era pra eu fazer alguma coisa. Mas eu não liguei, só na ânsia do trabalho. Aífoi doendo, doendo. [...] Eu senti a dor, a furada, eu tinha a obrigação de olhar, mas não olhei, não liguei. Ficou dormente, aífoi indo, foi indo, demorou uns 8 dias pra eu ir ao médico. (Rege, 47 anos)

A partir deste entendimento, os trabalhadores acreditam exercer uma gestão sobre os riscos, principalmente os relacionados a acidentes perfurocortantes, os mais identificados pelo grupo. É marcante a responsabilização do trabalhador pela prevenção. “A segurança é como fazer no dia a dia. É na base da gente conversar mesmo [...] Trabalhar com atenção”. (Jorge, 50 anos)

$\mathrm{O}$ enfrentamento do risco com naturalidade é difundido entre os mais experientes e está presente durante todo processo de trabalho. São as informações preventivas centradas na experiência e no bom senso do grupo que fortalecem os cooperativados na superação de limites, perigos e dificuldades diárias. $\mathrm{O}$ uso dos equipamentos de proteção individual também é tido como uma forma de enfrentamento da situação percebida como risco.

A prevenção de riscos está intimamente relacionada ao trabalho com alto nível de atenção que é difundido como sinônimo de proteção. Tem o poder de protegê-los, surgindo uma ideologia defensiva.

Se a situação for perigosa, eu vou! Eu me preparo, com muito cuidado, e vou fazer! A gente vai sempre trabalhar com esses riscos. Pra ser evitado, nós temos que nos proteger, Tomar cuidado! Proteção. (Rege, 47 anos)

Sim, a gente tem sempre atenção, cuidado [...] Se for uma caixa a gente tem o maior cuidado, se for um saco, pega com cuidado, pois pode se furar, ter algo cortante, ferro. [...] Tudo que a gente faz é com muito cuidado. (Iara, 47 anos)

Para o grupo, o uso de equipamentos de proteção individual (EPI) como luvas, botas, máscara, calça e roupas de manga comprida e o cuidado e a atenção na realização das atividades estão relacionados à segurança e à prevenção de acidentes. $\mathrm{O}$ equipamento de proteção individual mais utilizado pelo grupo é a luva.

A referência a equipamentos de proteção coletiva surge quando o cooperativado Jorge faz da mesa de triagem uma medida de prevenção: "Segurança 
é ter mesa de triagem pra não trabalhar agachado". O uso de fardas e o manuseio dos materiais afastados do corpo surgem como medidas de diminuição do risco de contaminação. O contato físico do resíduo sólido com o corpo está no discurso dos agentes como elemento propenso a acidentes e doenças.

Além disto, o trabalho em equipe para o grupo também é admitido como uma forma de enfrentar o risco. Como se o grupo de colegas, que se reconhece como pertencente a uma mesma família, fosse fator de segurança.

\section{Considerações finais}

Para concluir, podem ser destacados dois achados principais. $\mathrm{O}$ primeiro diz respeito às diferenças geracionais na produção de sentidos sobre saúde-doença, riscos ou segurança associados ao trabalho da reciclagem; um dado que perpassa todas as categorias analisadas: apriorísticas ou nativas. Há uma clara contradição entre a visão dos "mais jovens" e dos "mais velhos” ou "mais experientes”. Dentre os primeiros prevalece uma percepção mais crítica sobre as condições de trabalho na cooperativa, assim como uma noção mais acurada dos riscos associados ao trabalho que realizam.

Aqueles que são maiores de 47 anos, mesmo diante da constatação de sobrecarga ergonômica, postura inadequada, repetitividade, ritmo excessivo de trabalho, tendem a idealizar o trabalho que realizam, bem como ao ambiente da cooperativa, ao tempo em que negam o risco ergonômico. Neste grupo, os discursos, por um lado enaltecem o trabalho, símbolo de saúde, de vitalidade e de garantia de sobrevivência. Por outro lado, naturalizam o risco e hipertrofiam o poder de controle sobre esses. Prevalece uma postura de superação, difundida naquele universo, como requisito necessário ao enfrentamento da atividade laboral e como sinônimo de força.

O segundo achado aponta para a importância da hierarquia social, particularmente a divisão de trabalho no interior do grupo entre condições de trabalho. Ao refletir sobre os limites e contribuições da pesquisa realizada, destaca-se, dentre as lacunas, a ausência de contrapontos empíricos, considerando a realidade de outras cooperativas. Considera-se oportuno neste sentido a realização de novos estudos que considerem a análise comparativa de casos e explore mais profundamente o contexto do trabalho cooperativado.

Quanto às contribuições, aponta-se como um ponto forte a abordagem metodológica adotada, a qual privilegiou a escuta do ponto de vista dos trabalhadores a partir de suas experiências e universo simbólico, bem como a 
aproximação com a realidade cotidiana do trabalho com reciclagem de materiais sólidos no contexto de uma dada cooperativa. Uma perspectiva que converge com Navarro (2007), quando esse assinala que para compreender a produção dos riscos e doença no trabalho, enquanto processo moldado no agir individual e coletivo em situação de trabalho, será necessário acessar as histórias das situações de trabalho, as interações singulares entre a atividade humana e os meios técnicos e sociais que configuram o viver e o trabalhar em contextos específicos.

O mesmo autor nos ajuda a compreender a "aceitabilidade do risco", sentido que prevalece no grupo investigado, ao reconhecer que a percepção de risco associado ao trabalho extrapola a condição objetiva da exposição. Na avaliação subjetiva da equação, prejuízos-benefícios advindos da realização de uma dada atividade de trabalho, quando, em um determinado grupo prevalece a percepção de que os benefícios, envolvidos na atividade laboral em questão, são considerados superiores aos prejuízos, assim como a confiança no sistema regulador, a tendência é a minimização e aceitação dos riscos. (NAVARRO, 2007)

Por fim, é necessário refletir o que esses achados indicam para o campo da saúde do trabalhador e as políticas públicas nessa área. A defasagem entre as normas de segurança e o saber comum dos trabalhadores demanda que seja construída uma noção de risco ocupacional que integre a experiência do trabalhador às políticas de prevenção, possibilitando que o "saber técnico especializado possa servir como ferramenta de auxílio à prevenção” dos riscos nas atividades laborais. (NASCIMENTO; VIEIRA; CUNHA, 2010, p. 119) Além disso, desde o ponto de vista das políticas que perpassam os âmbitos do trabalho e da saúde, é preciso considerar a necessidade de apoiar os trabalhos das cooperativas, monitorando as ações neste contexto e atuando de forma conjunta na superação das fragilidades encontradas.

\section{Referências}

BRANDÃO, H. H. N. Introdução à análise do discurso. 2. ed. Campinas, SP:

UNICAMP, 2004 .

CARDOZO, M. Percepção de riscos ambientais de trabalhadores catadores de materiais recicláveis em um aterro controlado do município de Duque de Caxias, RJ. 20og. [107] f. Dissertação (Mestrado em Ciências na área de Saúde Pública e Meio Ambiente) Escola Nacional de Saúde Pública Sergio Arouca, Rio de Janeiro, 2009. 
CAVALCANTE, S.; FRANCO, M. F. A. Profissão perigo: percepção de risco à saúde entre os catadores do Lixão do Jangurussu. Revista Mal-estar e Subjetividade, Fortaleza, v. 7, n. 1, p. 211-231, mar. 2007.

CHAMON, E. M. Q. O.; MORAES, P. M. A representação social do risco em atividades potencialmente perigosas. Temas em Psicologia, Ribeirão Preto, v. 19, n. 1, p. 243-252, jun. 2011.

CRUZ, N. O. O trabalho de campo como descoberta e criação. In: MINAYO, M. C. S. (Org.). Pesquisa social: teoria, método e criatividade. Petrópolis, RJ: Vozes, 1994. Cap. 3, p. 51-64.

DOOK, J.; LONGNECKER, N.; MCGRATH, T. Development of a Risk Perception Web Portal and Training Tool. Calgary: Society of Petroleum Engineers, 2004.1 CD-ROM.

FERREIRA, J. A.; ANJOS, L. A. Aspectos de saúde coletiva e ocupacional associados à gestão dos resíduos sólidos municipais. Cadernos de Saúde Pública, Rio de Janeiro, v. 17, n. 3, p. 689-696, maio/jun. 2001.

FREITAS, C. M. A contribuição dos estudos de Percepção de Riscos na avaliação e no gerenciamento de riscos relacionados aos resíduos perigosos. In: SISINNO, C. L. S.; Oliveira, R. M. (Org.). Resíduos sólidos, ambiente e saúde: uma visão multidisciplinar. Rio de Janeiro: Fiocruz, 200o. p. 111-128.

GONÇALVES, R. C. M. A voz dos catadores de lixo em sua luta pela sobrevivência. 2005. 131 f. Dissertação (Mestrado em Políticas Públicas) - Universidade Estadual do Ceará, Fortaleza, 2005.

LUCCA, S. R.; CORTEZ, M. Z.; TOSETTO, T. A percepção dos trabalhadores sobre os riscos de distúrbios osteomusculares relacionados ao trabalho na produção de rosas. Revista Espaço de Diálogo e Desconexão, Araraquara, v. 4, n. 1, p. [1-17], jul./dez. 2011.

MAIA, H. J. L. Gestão integrada de resíduos sólidos para geração de renda e valorização de catadores e catadoras de materiais recicláveis organizados em associação. 2013.84 f. Dissertação (Mestrado em Recursos Naturais) - Universidade Federal de Campina Grande, Campina Grande, 2013.

MEDEIROS, L. F. R.; MACÊDO, K. B. Catador de material reciclável: uma profissão para além da sobrevivência? Psicologia \& Sociedade, Porto Alegre, v. 18, n. 2, p. 62-71, maio/ago. 2006.

MIURA, P. O. C. Tornar-se catador: uma análise psicossocial. 2004.165 f. Dissertação (Mestrado em Psicologia Social) - Pontifícia Universidade Católica de São Paulo, São Paulo, 2004. 
MOTTA, P. R. M. Ansiedade e medo no trabalho: a percepção do risco nas decisões administrativas. CONGRESO INTERNACIONAL DEL CLAD SOBRE LA REFORMA DEL ESTADO Y DE LA ADMINISTRACIÓN PÚBLICA, 7., 2002, Lisboa. Anais... Lisboa, 2002. p. 1-17.

NASCIMENTO, E. L. A.; VIEIRA, S. B.; CUNHA, T. B. Riscos ocupacionais: das metodologias tradicionais á análise das situações de trabalho. Fractal: revista de psicologia, Rio de Janeiro, v. 22, n. 1, p. 115-126, jan./abr. 2010.

NAVARRO, M. V. T. Conceito e controle de riscos à saúde em radiodiagnóstico: uma abordagem de vigilância sanitária. 2007·301 f. Tese (Doutorado em Saúde Pública) - Instituto de Saúde Coletiva, Universidade Federal da Bahia, Salvador, 2007 .

NOUROUDINE, A. Risco e atividades humanas: acerca da possível positividade aí presente. In: FIGUEIREDO, M. et al. (Org.). Labirintos do trabalho: interrogações e olhares sobre o trabalho vivo. Rio de Janeiro: DP\&A, 2004.

PORTO, M. F. S. Análise de riscos nos locais de trabalho: conhecer para transformar. São Paulo: Instituto Nacional de Saúde do Trabalhador: Central Única dos Trabalhadores, 200o. (Cadernos de Saúde do Trabalhador).

PORTO, M. F. S. et al. Lixo, trabalho e saúde: um estudo de caso com catadores em um aterro metropolitano no Rio de Janeiro, Brasil. Cadernos de Saúde Coletiva, Rio de Janeiro, v. 20, n. 6, p.1503-1514, nov./dez. 2004.

QUEIROZ, D. T. et al. Observação participante na pesquisa qualitativa: conceitos e aplicações na área da saúde. Revista Enfermagem UERJ, Rio de Janeiro, v. 15, n. 2, p. $276-283$, abr./jun. 2007.

ROSS, D. D.; KYLE, D. W. Qualitative inquiry: a review and analysis. Trabalho apresentado no Encontro Anual da Associação Americana de Pesquisa em Educação. Washington, D. C., 1982.

SILVA, B. V. Perfil sócio-demográfico e condições de saúde da população da Guiné-Bissau em 2002. 2005. 123 f. Dissertação (Mestrado em Demografia) Universidade Federal de Minas Gerais, Belo Horizonte, 2005.

VELLOSO, M. P.; SANTOS. E. M.; ANJOS, L. A. Processo de trabalho e acidentes de trabalho em coletores de lixo domiciliar na cidade de Rio de Janeiro, Brasil. Cadernos de Saúde Pública, Rio de Janeiro, v. 13, n. 4, p. 693-7oo, out./dez. 1997. 


\section{Além da etnografia olhares sobre o trabalho dos pesquisadores}

\section{CRISTINA LARREA KILLINGER}

\section{Introdução}

Neste capítulo apresento uma reflexão compreensiva da experiência etnográfica com foco nas relações entre os sujeitos nativos e pesquisadores durante e depois do trabalho de campo. Trato de pensar sobre os olhares, interações e diálogos que outros têm sobre a nossa atividade para aprofundar nossos compromissos e responsabilidades com a etnografia, que inclui as pessoas de que fazem parte. Indago o modo de perceber o que eles pensam sobre nós, sujeitos que observamos, escutamos e compartilhamos espaços e tempos comuns.

A partir de uma leitura compreensiva, exploro os sentidos e os significados de ser pesquisador e da atividade de campo a partir de exemplos etnográficos concretos situados num contexto cultural, sociopolítico e econômico particular. Apresento espaços de diálogo que geram a intensidade da relação e faz com que os nativos interpelem os pesquisadores para mostrar seus pontos de vistas sobre as atividades de pesquisa e da natureza da relação que estabelecem com o etnógrafo.

\section{Compartilhar a relação de sentido}

Os etnógrafos tratam de interpretar o que pessoas de outras culturas expressam sobre o mundo vivido e buscam compreender o sentido das 
formas simbólicas da cultura. O que os nativos pensam, fazem e sentem afeta o nosso olhar sobre eles e a nossa compreensão do mundo. Apesar da experiência empática que Malinowski aludia para compreender a cultura a partir de saber se colocar no lugar do outro, a crítica de Geertz se centrava na questão da compreensão do problema cultural. Para saber interpretar outra cultura é insuficiente ser somente um etnógrafo empático. Os etnógrafos buscam entender o que os outros acreditam que são e o que opinam sobre nós. Trata-se, pois, de uma tarefa hermenêutica. (GEERTZ, 1994)

Nessa busca, este capítulo se centra na fusão de horizontes para compreender como os nativos colocam os etnógrafos no mundo deles a partir das relações intersubjetivas que entre eles se constroem durante a pesquisa de campo. O que significa para os nativos a nossa atividade de pesquisa, e de que modo eles integram esses conhecimentos, os discutem e os comparam? É possível que o nativo se aproprie do olhar antropológico? Quando e como o nativo coloca o antropólogo como sujeito?

Em resumo, a questão é compreender o que os nativos pensam sobre os antropólogos e o que estes fazem - anotar, pesquisar, colaborar - em um espaço simbólico e temporal concreto. $\mathrm{O}$ fazer dos etnógrafos em campo conforma práticas de socialização, as quais transformam e redefinem a identidade dos etnógrafos, conferindo uma plasticidade que se situa na dinâmica da relação.

Para ilustrar essa discussão de caráter experimental desde uma perspectiva compreensiva, (MARCUS; FISCHER, 2000) apresento três exemplos de experiências etnográficas diferentes desenvolvidas no estado da Bahia. A primeira pesquisa de campo foi realizada num bairro periférico da cidade de Salvador da Bahia. ${ }^{1}$ A segunda em uma comunidade quilombola na região do Baixo Sul. ${ }^{2} \mathrm{E}$ a última em uma comunidade pesqueira do município de Nilo Peçanha. ${ }^{3}$

1 Etnografia de longa duração integrada num projeto interdisciplinar de avaliação epidemiológica sobre a implantação de um programa de saneamento ambiental. Abarcou um período de 44 meses, entre os anos 1997 e 2010

2 Trabalho de pesquisa integrado num projeto epidemiológico que consistia em avaliar as condições de saúde da população marisqueira. A etnografia durou 15 meses, distribuídos em distintas etapas entre os anos 2006 e 2012 .

3 As duas primeiras comunidades formavam parte de uma pesquisa de campo na região de extremo sul sobre a transição dos estudantes à secundária educação universitária que abarcou um total de seis meses 
Agrupamos esses exemplos em três interações de maior intensidade etnográfica que intitulamos "compartilhando saberes", "ações" e "afetos". Este conjunto responde a um processo de reflexão metodológico cuja ênfase é colocada sobre diferentes olhares e no modo de compartilhar que sempre implica no tempo de saberes, ações e afetos. Trata-se de uma relação de sentido e de conhecimento. (VIVEIROS DE CASTRO, 2002)

Nestas dinâmicas interativas entre pesquisadores e nativos, a intensidade etnográfica tem um papel fundamental como catalisador nesse processo. Defino a intensidade como a:

Atitude metodológica onde a reflexividade e a emoção ganham maior força durante a pesquisa de campo, facilitando um melhor processo de compreensão dos fenômenos observados. Esta intensidade, caracterizada por ser dinâmica, diversa, e irregular flui melhor quando certos imponderáveis do trabalho e acontecimentos imprevisíveis chegam a ser mais relevantes que os acontecimentos cotidianos. Os imponderáveis aos que me refiro como exemplo para analisar a intensidade etnográfica pertencem ao conjunto de discursos reflexivos e emotivos produzidos pelos atores sociais em diálogo com o antropólogo a um nível compreensivo. (LARREA-KILLINGER, 2011, p. 11-12, tradução nossa)

Nas interações, os saberes, as ações e os afetos formam um elo inseparável. Para "saber" tem que atuar e ser afetado pelo que se está conhecendo, descobrindo e aprendendo. Da mesma maneira, para "atuar", a pessoa parte do habitus e das emoções. Os "afetos" se desenvolvem com o "saber" e no mundo das ações cotidianas, apesar de que podem ganhar mais intensidade e força em situações imponderáveis durante a pesquisa de campo.

\section{Compartilhando saberes}

Durante o trabalho de campo nativos e etnógrafos estão inseridos em um mundo de relações em que olhares, interações e diálogos fazem par-

entre 2013 e 2014. No município de Nilo Peçanha, a comunidade de São Francisco foi escolhida porque as pessoas guardavam relações de parentesco com as que moravam na comunidade quilombola da segunda etnografia referida. Compararam-se as condições de saúde da população marisqueira e pesqueira, num total de quatro meses de pesquisa entre 2014 e 2015 
te da dinâmica do cotidiano. O que acontece é que em determinadas situações os nativos interpelam aos pesquisadores atuando como observadores do fazer do etnógrafo. Neste momento se inicia um diálogo sobre a natureza da pesquisa que motiva o etnógrafo a aprofundar sobre os limites do método e as formas de representação do que ele pretende fazer com os resultados de suas observações. O etnógrafo trata de compreender o significado subjetivo de suas ações no diálogo com o outro. Trata-se de uma relação intersubjetiva. (SCHÜTZ, 20oo) Neste caso, as ações que incluem esta relação partem do ato de escrever, anotar e registrar as observações na pesquisa de campo.

O exemplo que apresento tem a ver com uma situação imponderável situada na comunidade quilombola do Baixo Sul da Bahia, onde fui acolhida pela primeira vez pela família da presidenta da associação de moradores em 2006. Compartilhava um quarto com uma das suas filhas e um dos filhos, numa comunidade de 120 pessoas. As casas eram na sua maioria de taipa e estavam distribuídas em três caminhos de areia. Moravam em unidades domésticas nucleares, mas guardavam relações de parentesco entre todas elas. A maioria dos adultos com mais de 30 anos não sabia ler nem escrever, e os jovens de mais de 15 anos tinham deixado a escola sem concluir o ensino fundamental. Somente eram as crianças e as meninas jovens que estudavam na escolinha da comunidade ou em escolas de nível primário e secundário em comunidades vizinhas.

Quando fui morar na comunidade comecei a visitar as casas com o fim de estabelecer os primeiros contatos com os adultos. A excessiva timidez e desconfiança, mesmo tendo sido convidada pela comadre da presidenta e ser aceita na celebração da assembleia da associação, impedia estabelecer uma relação fluída entre todos nós. Após várias visitas às famílias, percebi que continuavam incomodadas com a minha presença e observei que não gostavam de conversar e responder perguntas. Decidi aguardar que fossem elas que iniciassem as conversas e que se aproximassem de mim. Visitei-as menos para ganhar maior confiança e fiquei aguardando no terreno da presidenta onde havia um pequeno quiosque com mesas e bancas, no qual nos fins de semanas os parentes e pessoas de outras comunidades se encontravam para se divertir com bebidas e danças. A casa da presidenta da associação era muito frequentada por adultos e crianças porque havia um pequeno comércio no qual compravam produtos básicos de consumo. Aliás, as mulheres eram as que mais 
frequentavam este local porque havia uma fonte que usavam duas vezes por dia para coletar água.

$\mathrm{O}$ fato de haver decidido aguardar as pessoas a se aproximarem foi a melhor opção para propiciar um diálogo. Aprendi a fazer observação em silêncio. Observei que o silêncio era valorizado na comunidade, na rotina do cotidiano, e que as conversas e gargalhadas eram propiciadas com o trago de bebida alcoólica - cachaça e cerveja -, a dança e a música própria do descanso do fim de semana.

Tempos depois, compreendi que elas não estavam acostumadas a conversar com pessoas "estranhas" dentro da casa. O lugar público para conversar era o quiosque ou nos terrenos dos fundos das casas onde se comentavam os problemas. Elas conversavam pouco quando faltava cerveja, cachaça e música. Percebi que ao fazer indagações sem ser parente, e não ter intimidade, poderia ser classificada como "fofoqueira" e por isso ser rejeitada. Não há pior insulto que esse no lugar.

$\mathrm{Na}$ posição de observadora silenciosa, as mulheres carregando baldes na cabeça olhavam para mim enquanto passavam por atrás do quiosque em direção à fonte. As crianças foram as únicas que se aproximaram e sentaram-se ao meu lado, enquanto eu fazia anotações. No dia que decidiram fazer isso, uma das meninas pediu uma folha do meu caderno e uma caneta para desenhar. Imediatamente o resto do grupo imitou o mesmo pedido e o meu caderno de anotações se transformou em desenhos que as crianças me entregaram com as observações do mundo deles. Dialogamos através de folhas de papel, desenhos e anotações.

Essa atividade se prolongou como uma brincadeira. A minha atividade de escritura era compartilhada pelo interesse das crianças em me obsequiar com desenhos de casas, árvores e pássaros bem coloridos com o nome de autoria embaixo. Tratava-se de uma atividade voraz e competitiva entre eles para me agradar e chamar a minha atenção. Com o decorrer dos dias as folhas acabaram, então sugeri que pintassem mais os desenhos, com os lápis de cor que os presenteei. Surpreendia-me a rapidez com que pediam folhas de papel e me devolviam seus desenhos. E um dia perguntei por que desenhavam tão rápido. Uma das crianças me respondeu que desenhavam na mesma velocidade que eu escrevia no meu caderno. Várias crianças disseram querer usar as cores na mesma velocidade que eu usava a minha caneta, pois se eu anotava muitas coisas eles desejavam me mostrar muitas coisas. Para dialogar comigo tratavam de me imitar. 
A troca de nossos mundos consistia em mostrar a minha caligrafia e ler palavras do meu caderno, algumas das quais achavam divertidas. Por enquanto eles me entregavam desenhos de pássaros, flores e árvores, escrevendo o meu nome adornado com corações e palavras de carinho. Mais tarde, essa dinâmica de diálogo passou a outro plano. Queriam que lhes ensinasse canções e jogos infantis do meu mundo. Aprendi a traduzi-las e a brincar com eles.

Essa experiência começou a ser enxergada com curiosidade pelas mães. A presidenta da associação me pediu que durante a semana se desse aulas à tarde para as crianças, quando voltassem da escola, aos jovens que haviam deixado a escola, e aos adultos que não sabiam ler nem escrever. $O$ fato de me converter em uma "professora” facilitou a minha aceitação como membro da comunidade. Com esta atribuição, as mulheres começaram a conversar comigo. $\mathrm{O}$ meu interesse por iniciar temas de conversas relacionados com o objetivo da pesquisa e de visitá-las na casa delas começaram a ser bem aceitas.

Conversar sobre "pesquisa" fazia sentido nas atividades escolares. Esse termo era conhecido pelas crianças e também pelas mães. Quando as crianças chegavam em casa diziam que as professoras haviam solicitado pesquisar algum assunto no livro, procurar na internet, na escola ou perguntar na comunidade. $\mathrm{O}$ mundo da pesquisa estava relacionado com o conhecimento e o uso da tecnologia. Eu fazia parte desse mundo de fora. Nessa troca compartilhávamos saberes que tinham sentido, como processo de intercambio. Aprendi a evitar as perguntas diretas, consideradas como falta de respeito, a escutar, a sentir e aprender com curiosidade as atividades do cotidiano.

No curso dos jovens que haviam abandonado a escola, o processo foi parecido. Interessada no método de alfabetização de Paulo Freire, decidi aplicar uma série de aulas informais em que os jovens escolheram como assunto gerador um tema da natureza. Todas as leituras se centraram em falar da natureza ao redor e compará-la a outras regiões brasileiras. Procurei livros de biologia emprestados da biblioteca situada no povoado vizinho e ao mostrá-los se interessaram em comparar as espécies de animais. Quando souberam de que eu tinha uma câmara fotográfica solicitaram, como uma das práticas, fotografar a natureza da ilha onde moravam. Ninguém naquela época tinha câmera e telefone celular, o que despertou muita curiosidade poder fotografar o mato e o mangue. Da natureza, o principal mundo fotografado foi o dos pássaros, espécies selvagens que consideravam mais pró- 
ximas ao reino humano. Quando fotografei animais e os lugares de morada como as árvores, os ninhos e os buracos, sempre eu estava em companhia das crianças e jovens. Seguindo em ordem de importância foram fotografados também os animais que asseguravam o sustento diário, como diversas espécies de mariscos e animais de caça. Nas explicações que deram sobre essas fotografias centraram o debate na comparação entre o comportamento dos humanos e dos animais. $\mathrm{O}$ animal do mato mais humanizado foi o pássaro, este que as pessoas gostavam de pegar do ninho e criar como um filho.

As crianças preferiram fotografar o movimento. As brincadeiras como: dançar, pular, correr ou subir em árvores, foram considerados os desafios mais importantes. Exemplo de crianças subindo árvores enormes e compridas, ou correndo para desafiar o foco da câmera, desafiava a destreza do fotógrafo. Deixei que fossem as crianças as que fotografassem as cenas de que mais gostassem. Preferiam fotografar os animais em liberdade e não os presos em gaiolas como os pássaros, ou os amarrados como os cachorros. As crianças escolhiam ser o centro da imagem sempre em grupo e acompanhados de cenas onde dominavam as árvores, flores e animais de estimação fora da casa.

Um ano depois, quando retornei a campo, uma jovem havia comprado uma câmera, e aos poucos foi se introduzindo o uso do telefone celular. A mesma jovem continuou com os cursos de reforço escolar para as crianças e depois se transformou em fotógrafa de festas e eventos da comunidade. No dia da inauguração da construção da associação, ela fez fotografias assim como no dia da festa de São Cosme e São Damião. Além de fotografar pela primeira vez a mãe quando incorporou os santos caboclos, entregou mais tarde uma cópia digital para mim do que havia fotografado para compartilhar comigo o que para ela era o seu mundo. Naquela época, ela havia terminado o ensino médio e estava pensando em fazer faculdade.

\section{Compartilhando ações}

Trata-se do processo de observação que os nativos fazem sobre os projetos de pesquisa-ação e dinâmicas participativas de projetos universitários ou de ONGs. Os nativos comparam diferentes estilos de pesquisa e participação e adotam determinadas posições diante dos pesquisadores e opiniões sobre as pesquisas. Relações de poder e tensões sociais se desencadeiam 
entre os nativos que buscam determinado reconhecimento entre os pesquisadores em etapas de maior visibilidade da pesquisa, como é o processo de transferência do conhecimento.

O seguinte exemplo etnográfico se situa no bairro periférico de Salvador na Bahia. Em 2007, iniciou-se a última etapa da pesquisa dez anos depois com a elaboração de um documentário em vídeo sobre as condições de saneamento solicitado pelos moradores do bairro. A filmagem foi finalizada em um mês com o apoio de muitos moradores e de uma ajudante de câmera. Não houve recursos econômicos para a filmagem nem para a edição, sendo que o custo assumido por mim a ajudante de câmera durante a produção e por um amigo. $\mathrm{O}$ objetivo foi de compartilhar com os nativos os resultados da pesquisa e disponibilizá-los para fortalecer os processos participativos e assim iniciar demandas à prefeitura municipal para as melhorias no bairro.

O processo de elaboração do documentário foi colaborativo, pois incluiu a tomada de decisões do roteiro por parte dos entrevistados e uma visualização prévia da primeira edição um ano depois. Os moradores se implicaram durante a filmagem, acompanhando-nos das casas e nas principais localizações do bairro, evitando assim os riscos de assalto pelo transporte da câmera. Também se responsabilizaram em guardar a câmera à noite e em facilitar moradia e apoio durante as entrevistas.

O imponderável, que levou a questionar este processo, aconteceu uma semana depois da gravação, quando uma das lideranças do bairro que eu conhecia há anos comentou a uma das minhas principais informantes que estávamos elaborando a filmagem ilegalmente por não ter solicitado aos entrevistados a permissão de suas imagens. Chamou-me a atenção que a liderança reclamasse esse documento quando a nossa intenção com o documentário não era passá-lo pela televisão, ou circulá-lo por festivais, mas bem se tratava do cumprimento de um pedido colaborativo para compartilhar os resultados da pesquisa com as pessoas do bairro. Para nós não era preciso esse documento, pois já contávamos com o atestado do comitê de ética da pesquisa desde 1997 e, sobretudo, porque se tratava de um pedido da comunidade.

A minha informante me recomendou que fosse pessoalmente à reunião da associação de moradores para apresentar a proposta de documentário e, desse modo, evitar que se espalhasse na rua que nós estávamos nos aproveitando dessa filmagem para "ganhar dinheiro". 
A minha informante insistiu que elaborássemos o documento de direitos de imagem para evitar problemas. Algumas pessoas do bairro não confiavam na liderança que estava à frente da associação. A liderança tinha uma fraca coesão interna no bairro, mas mantinha fortes conexões com lideranças políticas e representantes de uma ONG de fora do bairro. Exigia uma formalização para a filmagem que parecia inicialmente desnecessária para minha equipe e para os moradores do bairro, porque a produção do documentário se baseava na confiança e em um pedido da comunidade. Mas se converteu em uma exigência que os moradores consideraram como medida de proteção contra as possíveis más intenções da liderança.

Com este exemplo, observamos que a liderança tinha uma visão distinta sobre as exigências legais no processo de elaboração do documentário. Um processo colaborativo que partia de uma experiência etnográfica foi reduzido a um processo participativo formalizado, que exigia protocolos bem conhecidos por esta liderança e desnecessários para essa experiência.

Depois compreendi que a formalização do processo era necessária para evitar a confrontação interna entre algumas pessoas do bairro e a liderança, sobretudo para não suspender a produção. A cessão de direitos de imagem foi um documento incluído, uma vez iniciada a filmagem sem problemas por parte dos entrevistados. Esse imponderável me levou a refletir sobre a variedade de processos participativos e as tensões internas que poderiam ter aflorado caso se confrontasse a opinião da liderança com a dos moradores.

\section{Compartilhando afetos}

Trata-se de mergulhar na implicação de afetos e emoções entre informantes e pesquisadores durante e depois da pesquisa de campo. A construção dos afetos sofre etapas de maior ou menor intensificação entre pessoas, $\mathrm{e}$ momentos concretos que podem levar a demandas complexas com risco ao comprometimento de pesquisa e da própria identidade do pesquisador. Indago mais sobre contextos de maior proximidade e intimidade do que sobre regras de hospitalidade próprias da convivência.

Este último exemplo etnográfico se situa no município de Nilo Peçanha, em 2013. Quanto maior era o tempo de convívio e de aceitação na comunidade, maior era a possibilidade de sofrer os mesmos perigos e riscos. $\mathrm{O}$ imponderável aconteceu um dia em que, estando na casa de uma marisqueira 
e do primo dela colaborando no processo de catação de caranguejo, a visita de uma vizinha provocou um problema de "mau olhado".

Na casa de Marta, e em companhia do primo, ficamos um sábado à tarde, catando caranguejo, sentados no chão diante de um balde de plástico, conversando e escutando música, quando entrou uma vizinha. A senhora Teresa ficou admirada ao ver como eu batia com um pauzinho a casca das pernas dos caranguejos e extraia com os dedos a carne. Com pouca habilidade, mas com paciência, eu imitava os movimentos de Marta. Queria aprender o trabalho de catador e compartilhar um sábado à tarde com ela e o seu primo que também nos ajudava nessa tarefa.

Dona Teresa começou a falar bem de mim, de como se admirava que uma "branca estrangeira" fizesse esse trabalho que muitas jovens evitavam, como, por exemplo, as próprias netas. Antes de se aposentar trabalhou muito como marisqueira e se queixou da hipertensão, das dores nas mãos, nos braços e nos joelhos como consequência dessa atividade. As queixas sobre o próprio corpo eram amenizadas com o valor atribuído à venda do catado para ajudar na sobrevivência da família.

Quando Teresa saiu da sala, comecei a bocejar e a me sentir cansada e fraca. Marta e o primo dela observaram o meu decaimento e começaram a falar entre eles que a senhora Teresa me havia provocado o "mau olhado" por excesso de adulação e admiração. A inveja involuntária era perigosa e signo inequívoco do mau olhado, e por isso Marta e o primo decidiram que deixasse de catar caranguejo e me deitasse no sofá.

Diante dessa constatação do mau olhado começaram a dar gargalhadas. Marta e o primo não pararam de rir ao ver que sendo branca e estrangeira também podia ser afetada pelo olho de uma pessoa do lugar. Decidiram que deveriam me levar a uma rezadeira. Mas pela manhã havia melhorado, indicaram-me um banho de folhas do mato. Um banho de "descarga", ou descarrego, para me proteger da possibilidade de reaparecer o "olhado". $\mathrm{O}$ primo me recomendou colocar um dente de alho no bolso sempre que saísse de casa para evitar o mal.

Tanto Marta quanto o primo constataram a minha vulnerabilidade diante de problemas comuns como o olhado. Apesar de saber que os brancos e estrangeiros não acreditavam nessas crenças, no fundo se sentiam contentes de haver comprovado que o risco da inveja afetava a outras pessoas que não eram da comunidade. Reconheciam que os brancos - médicos, técnicos 
e pesquisadores - não consideravam suas crenças como condicionantes de problemas de saúde. Preferiam não falar desses assuntos durante as visitas de pesquisadores ou técnicos, para não escutarem piadas contra suas crenças. Eles se perguntavam por que me haviam afetado desse modo. E a resposta mais convincente para eles é que eu compartilhava de suas crenças, por isso podia sentir.

A aceitação na comunidade passou a outro plano mais profundo por ser alvo dos mesmos riscos, já que para eles simbolicamente compartilhava as mesmas crenças. Segundo eles, isso me capacitava para poder compartilhar a mesma eficácia simbólica no processo de cura. Os banhos de descarga e fechamento do corpo passaram a ocupar outra das práticas de integração a uma cultura. $\mathrm{O}$ sentido de pertença não passava somente por dominar uma língua e apreender habilidades técnicas, mas também a sofrer processos de adoecimento e compartilhar perigos simbólicos.

\section{Um modo de conclusão}

Os exemplos ilustram parte do jogo de sentidos na relação entre nativos e antropólogos, em que o discurso nativo e o antropológico se confundem. O antropólogo deixa de ser etnógrafo porque a identidade é confusa ou por ter entrado em crise para o olhar nativo, e este, o nativo, se apropria de uma visão crítica do fazer do etnógrafo. Nessa fusão de horizontes, o sujeito nativo se revela como sujeito que dialoga a um nível mais simétrico. (VIVEIROS DE CASTRO, 2002) O nativo está menos sujeito ao discurso do antropólogo e mais liberado para penetrar nos procedimentos do etnógrafo. O nativo interpela ativamente o antropólogo. Na estrutura pré dada da relação se percebe uma alternância em que observamos o nativo mais antropólogo e o etnógrafo mais nativo. Essas possibilidades do jogo no campo são temporárias e situadas num contexto particular.

$\mathrm{O}$ fato de se basear em exemplos permite abrir uma reflexão sobre os imponderáveis no campo e a plasticidade das relações. O antropólogo chega a ser mais nativo (TEDLOCK, 1991) com o último exemplo, e o nativo mais antropólogo nos outros exemplos. Assim, ao dialogar de modo mais interativo, antropólogos e nativos conseguem construir pontes mais simétricas e humanas. 


\section{Referências}

GEERTZ, C. Conocimiento local: ensayos sobre la interpretación de las culturas. Barcelona: Paidós Ibérica, 1994.

LARREA-KILLINGER, C. Intensidad etnográfica: reflexividad y emoción en el trabajo de campo. Ankulegi, Donostia, n. 15, p. 11-22, 2011.

MARCUS, G.; FISCHER, M. J. La antropología como crítica cultural: un momento experimental en las ciencias humanas. Buenos Aires: Amorrortu, 2000.

SCHÜTZ, A. La construcción significativa del mundo social: introducción a la sociología comprensiva. Barcelona: Paidós Ibérica, 2000.

TEDLOCK, B. From participant observation to the observation of participation: the emergence of narrative ethnography. Journal of Anthropological Research, Chicago, v. 47, n. 1, p. 69-94, 1991.

VIVEIROS DE CASTRO, E. O nativo relativo. Mana, Rio de Janeiro, v. 8, n. 11, p. $113-148$, abr. 2002. 


\section{Sobre os autores}

\section{Ana Carolina Nascimento de Albuquerque Ramos}

Assistente Social, mestre em Saúde, Ambiente e Trabalho pelo Programa de Pós-Graduação em Saúde, Ambiente e Trabalho (PPGSAT), Faculdade de Medicina da Bahia (FMB), Universidade Federal da Bahia (UFBA).

\section{Claúdia D'Arede}

Antropóloga, mestre em Saúde, Ambiente e Trabalho pelo Programa de Pós-graduação em Saúde, Ambiente e Trabalho (PPGSAT), Faculdade de Medicina da Bahia (FMB), Universidade Federal da Bahia (UFBA), doutoranda em Ciências Sociais, professora colaboradora do PPGSAT.

\section{Cristina Larrea Killinger}

Antropóloga, doutora em Antropologia pela Universidade de Barcelona, professora do Departamento de Antropologia da Universitat de Barcelona. 


\section{Denise Alves Miranda de Oliveira}

Enfermeira, mestre em Saúde, Ambiente e Trabalho pelo Programa de Pós-graduação em Saúde, Ambiente e Trabalho (PPGSAT), Faculdade de Medicina da Bahia (FMB), Universidade Federal da Bahia (UFBA).

\section{Jorge Henrique Santos Saldanha}

Fisioterapeuta, mestre em Saúde, Ambiente e Trabalho Programa de Pós-graduação em Saúde, Ambiente e Trabalho (PPGSAT), Faculdade de Medicina da Bahia (FMB), Universidade Federal da Bahia (UFBA), doutorando em Saúde Pública pelo Instituto de Saúde Coletiva (ISC) da UFBA.

\section{Kênya Lima Araújo}

Nutricionista, mestre em Saúde, Ambiente e Trabalho do Programa de Pós-graduação em Saúde, Ambiente e Trabalho (PPGSAT), Faculdade de Medicina da Bahia (FMB), Universidade Federal da Bahia (UFBA), doutoranda em Alimentos, Saúde e Nutrição pela UFBA.

\section{Luiz Roberto Santos Moraes}

Engenheiro Sanitarista, doutor em Saúde Ambiental pela Universit of London, Inglaterra. Professor titular do Departamento de Engenharia Ambiental da Escola Politécnica da Universidade Federal da Bahia (UFBA).

\section{Manoel Henrique de Miranda Pereira}

Enfermeiro, mestre em Saúde, Ambiente e Trabalho pelo Programa de Pós-graduação em Saúde, Ambiente e Trabalho (PPGSAT), Faculdade de Medicina da Bahia (FMB), Universidade Federal da Bahia (UFBA).

\section{Maria do Carmo Soares de Freitas}

Nutricionista, doutora em Saúde Pública pelo Instituto de Saúde Coletiva (ISC) da Universidade Federal da Bahia (UFBA), professora associada do Departamento de Nutrição da UFBA. 


\section{Mônica Angelim Gomes de Lima}

Médica do Trabalho e Sanitarista, doutora em Saúde Pública pelo Instituto de Saúde Coletiva (ISC) da Universidade Federal da Bahia (UFBA), professora associada do Departamento de Medicina Preventiva e Social da Faculdade de Medicina da Bahia (FMB), da Universidade Federal da Bahia (UFBA).

\section{Paulo Gilvane Lopes Pena}

Médico do Trabalho, doutor em Ciências Sociais pela École de Hautes Études em Sciences Sociales (EHESS-PARIS), professor associado do Departamento de Medicina Preventiva e Social da Faculdade de Medicina da Bahia (FMB), da Universidade Federal da Bahia (UFBA).

\section{Rita de Cássia Pereira Fernandes}

Médica do Trabalho e Sanitarista, doutora em Saúde Pública pelo Instituto de Saúde Coletiva (ISC) da Universidade Federal da Bahia (UFBA), professora associada do Departamento de Medicina Preventiva e Social da Faculdade de Medicina da Bahia (FMB), da Universidade Federal da Bahia (UFBA).

\section{Robson da Fonseca Neves}

Fisioterapeuta, doutor em Saúde Pública pelo Instituto de Saúde Coletiva (ISC) da Universidade Federal da Bahia (UFBA), professor adjunto do Departamento de Fisioterapia da Universidade Federal da Paraíba (UFPB).

\section{Saulo Robledo Cardoso}

Administrador, mestre em Saúde, Ambiente e Trabalho pelo Programa de Pós-graduação em Saúde, Ambiente e Trabalho (PPGSAT), Faculdade de Medicina da Bahia (FMB), Universidade Federal da Bahia (UFBA). 


\section{Sérgio do Nascimento Silva Trad}

Sociólogo, doutor em Antropologia Médica, Universitát Rovira i Virgili URV - Espanha, professor visitante do Programa de Pós-graduação em Saúde, Ambiente e Trabalho (PPGSAT) na Universidade Federal da Bahia (UFBA).

\section{Tarciso de Figueiredo Palma}

Ciências da Computação, mestre em Saúde, Ambiente e Trabalho pelo Programa de Pós-graduação em Saúde, Ambiente e Trabalho (PPGSAT), Faculdade de Medicina da Bahia (FMB), Universidade Federal da Bahia (UFBA).

\section{Thais Mara Dias Gomes}

Fisioterapeuta, mestre em Saúde, Ambiente e Trabalho pelo Programa de Pós-graduação em Saúde, Ambiente e Trabalho (PPGSAT), Faculdade de Medicina da Bahia (FMB), Universidade Federal da Bahia (UFBA), doutoranda em Saúde Pública pelo Instituto de Saúde Coletiva (ISC) da UFBA. 
E ste livro foi produzido em formato 170 x $240 \mathrm{~mm}$ com miolo em papel Alta Alvura $75 \mathrm{~g} / \mathrm{m}^{2}$ capa em Cartão Supremo $300 g / \mathrm{m}^{2}$, impressa na I. Bigraf. Tiragem: 400 exemplares. 